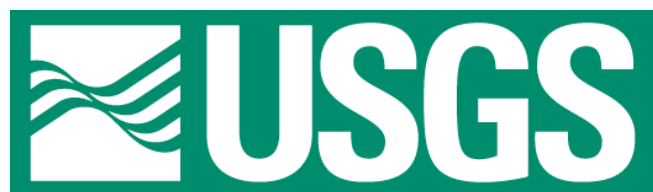

\title{
2009 Weather and Aeolian Sand-Transport Data from the Colorado River Corridor, Grand Canyon, Arizona
}

By Amy E. Draut, Hoda A. Sondossi, Timothy P. Dealy, Joseph E. Hazel, Jr., Helen C. Fairley, and Christopher R. Brown

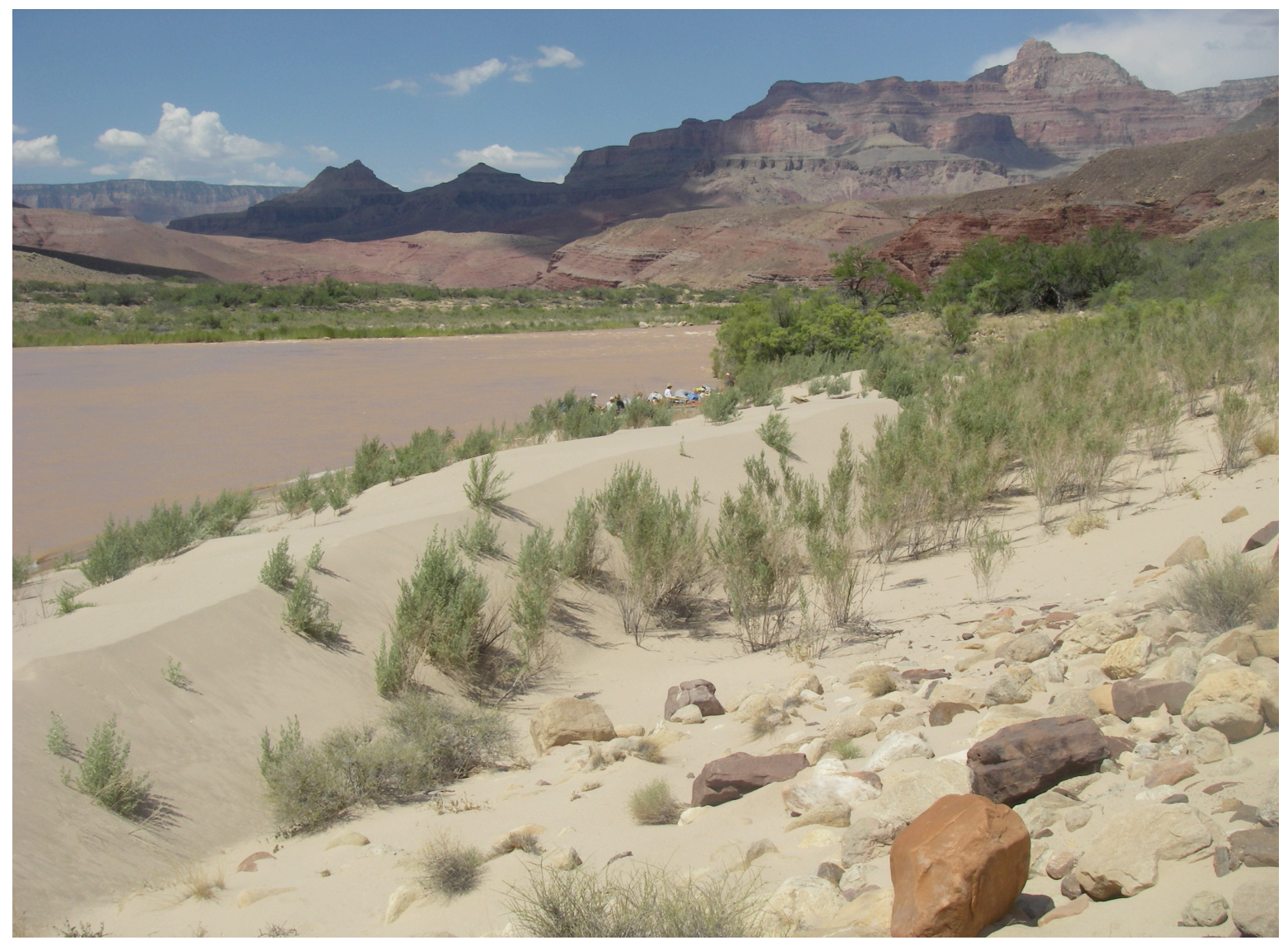

Open-File Report 2010-1166

U.S. Department of the Interior

U.S. Geological Survey 


\title{
U.S. Department of the Interior \\ KEN SALAZAR, Secretary
}

\author{
U.S. Geological Survey \\ Marcia K. McNutt, Director
}

U.S. Geological Survey, Reston, Virginia 2010

For product and ordering information:

World Wide Web: http://www.usgs.gov/pubprod

Telephone: 1-888-ASK-USGS

For more information on the USGS - the Federal source for science about the Earth, its natural and living resources, natural hazards, and the environment:

World Wide Web: http://www.usgs.gov

Telephone: 1-888-ASK-USGS

Suggested citation:

Draut, A.E., Sondossi, H.A., Dealy, T.P., Hazel, J.E. Jr., Fairley, H.C., and Brown, C.R., 2010, 2009 weather and aeolian sand-transport data from the Colorado River corridor, Grand Canyon, Arizona: U.S. Geological Survey Open-File Report 2010-1166, 98 p. [http://pubs.usgs.gov/of/2010/1166/]

Any use of trade, product, or firm names is for descriptive purposes only and does not imply endorsement by the U.S. Government.

Although this report is in the public domain, permission must be secured from the individual copyright owners to reproduce any copyrighted material contained within this report. 


\section{Contents}

List of Figures

\section{Figures}

1. Colorado River corridor through Grand Canyon, Ariz., showing study sites.........34

2. Photograph of instrument station at AZ A:15:0033...........................................35

3. Photographs of the sandbar near AZ C:05:0031 before, 3 weeks after, and 16 months after the 2008 High-Flow Experiment (HFE). .........................................36

4. Surveyed profiles of the sandbar near AZ C:05:0031 before and after the 2008 High-Flow Experiment (HFE).

5. Aerial photograph of the area around AZ C:05:0031, in Grand Canyon, Ariz., with arrow indicating net direction of potential aeolian sediment transport measured at AZ C:05:0031 L in 2009.

6. Wind speed and direction measured at the instrument station AZ C:05:0031 L in the Colorado River corridor, Grand Canyon, Ariz., in 2009.

7. Cumulative 2009 rainfall record measured at AZ C:05:0031 L.............................40

8. Wind, rainfall, and aeolian sand-transport data collected at the instrument station AZ C:05:0031 L in the Colorado River corridor, Grand Canyon, Ariz., in 2008 and 2009. 
9. Temperature, humidity, and barometric pressure data collected at the instrument station AZ C:05:0031 L in the Colorado River corridor, Grand Canyon, Ariz., in 2008 and 2009. All parameters are plotted as diurnal averages (defined using 0600-1800 and 1800-0600 hours).

10. Aerial photograph of the area around AZ C:05:0031, in Grand Canyon, Ariz., with arrow indicating net direction of potential aeolian sediment transport measured at the instrument station AZ C:05:0031 U in 2009.

11. Wind speed and direction measured at the instrument station AZ C:05:0031 U in the Colorado River corridor, Grand Canyon, Ariz., in 2009.

12. Cumulative 2009 rainfall record measured at AZ C:05:0031 U.

13. Wind, rainfall, and aeolian sand-transport data collected at the instrument station AZ C:05:0031 U in the Colorado River corridor, Grand Canyon, Ariz., in 2008 and 2009.

14. Temperature, humidity, and barometric pressure data collected at the instrument station AZ C:05:0031 U in the Colorado River corridor, Grand Canyon, Ariz., in 2008 and 2009.

15. Photographs of the sandbar near AZ C:13:0365 before, 3 weeks after, and 16 months after the 2008 High-Flow Experiment (HFE).

16. Photograph of aeolian dune on sandbar at AZ C:13:0365 in July 2008 and July 2009.

17. Surveyed profiles of the sandbar near AZ C:13:0365 before and after the 2008 High-Flow Experiment (HFE).

18. Aerial photograph of the area around AZ C:13:0365, in Grand Canyon, Ariz., with arrow indicating net direction of potential aeolian sediment transport measured at instrument station AZ C:13:0365 L in 2009.

19. Wind speed and direction measured at the instrument station AZ C:13:0365 L in the Colorado River corridor, Grand Canyon, Ariz., in 2009.

20. Cumulative 2009 rainfall record measured at AZ C:13:0365 L.

21. Wind, rainfall, and aeolian sand-transport data collected at the instrument station AZ C:13:0365 L in the Colorado River corridor, Grand Canyon, Ariz., in 2008 and 2009.

22. Temperature, humidity, and barometric pressure data collected at the instrument station AZ C:13:0365 L in the Colorado River corridor, Grand Canyon, Ariz., in 2008 and 2009.

23. Aerial photograph of the area around AZ C:13:0365, in Grand Canyon, Ariz., with arrow indicating net direction of potential aeolian sediment transport measured at instrument station AZ C:13:0365 U in 2009.

24. Wind speed and direction measured at the instrument station AZ C:13:0365 U in the Colorado River corridor, Grand Canyon, Ariz., in 2009.

25. Cumulative 2009 rainfall record measured at AZ C:13:0365 U....

26. Wind, rainfall, and aeolian sand-transport data collected at the instrument station AZ C:13:0365 U in the Colorado River corridor, Grand Canyon, Ariz., in 2008 and 2009.

27. Temperature, humidity, and barometric pressure data collected at the instrument station AZ C:13:0365 U in the Colorado River corridor, Grand Canyon, Ariz., in 2008 and 2009.

28. Aerial photograph of the area around AZ C:13:0006, in Grand Canyon, Ariz., with arrow indicating net direction of potential aeolian sediment transport measured in 2009. 
29. Wind speed and direction measured at the instrument station AZ C:13:0006 in the Colorado River corridor, Grand Canyon, Ariz., in 2009.

30. Cumulative 2009 rainfall record measured at AZ C:13:0006.

31. Wind, rainfall, and aeolian sand-transport data collected at the instrument station AZ C:13:0006 in the Colorado River corridor, Grand Canyon, Ariz., in 2008 and 2009.

32. Temperature, humidity, and barometric pressure data collected at the instrument station AZ C:13:0006 in the Colorado River corridor, Grand Canyon, Ariz., in 2008 and 2009.

33. Photographs of the sandbar near AZ C:13:0336 before and after the 2008 High-Flow Experiment (HFE).

34. Aerial photograph of the area around AZ C:13:0336, in Grand Canyon, Ariz., with arrow indicating net direction of potential aeolian sediment transport measured in 2009.

35. Wind speed and direction measured at the instrument station AZ C:13:0336 U in the Colorado River corridor, Grand Canyon, Ariz., in 2009.

36. Cumulative 2009 rainfall record measured at AZ C:13:0336 U

37. Wind, rainfall, and aeolian sand-transport data collected at the instrument station AZ C:13:0336 U, and aeolian sand-transport data collected from sand traps at AZ C:13:0336 L, in the Colorado River corridor, Grand Canyon, Ariz., in 2008 and 2009.

38. Temperature, humidity, and barometric pressure data collected at the instrument station AZ C:13:0336 U in the Colorado River corridor, Grand Canyon, Ariz., in 2008 and 2009.

39. Photographs of the sandbar near AZ C:13:0321 before and after the 2008 High-Flow Experiment (HFE).

40. Surveyed profiles of the sandbar near AZ C:13:0321 before and after the 2008 High-Flow Experiment (HFE).

41. Aeolian sand-transport data collected near AZ C:13:0321 in 2009.

42. Aerial photograph of the area around AZ C:13:0346, in Grand Canyon, Ariz., with arrow indicating net direction of potential aeolian sediment transport measured at instrument station AZ C:13:0346 L in 2009.

43. Wind speed and direction measured at the instrument station AZ C:13:0346 L in the Colorado River corridor, Grand Canyon, Ariz., in 2009. ……....................75

44. Cumulative 2009 rainfall record measured at AZ C:13:0346 L............................76

45. Wind, rainfall, and aeolian sand-transport data collected at the instrument station AZ C:13:0346 L, in the Colorado River corridor, Grand Canyon, Ariz., in 2008 and 2009 .

46. Temperature, humidity, and barometric pressure data collected at the instrument station AZ C:13:0346 L in the Colorado River corridor, Grand Canyon, Ariz., in 2008 and 2009.

47. Aerial photograph of the area around AZ C:13:0346, in Grand Canyon, Ariz., with arrow indicating net direction of potential aeolian sediment transport measured at instrument station AZ C:13:0346 U in 2009.

48. Wind speed and direction measured at the instrument station AZ C:13:0346 U in the Colorado River corridor, Grand Canyon, Ariz., in 2009.

49. Cumulative 2009 rainfall record measured at AZ C:13:0346 U 
50. Wind, rainfall, and aeolian sand-transport data collected at the instrument station AZ C:13:0346 U, in the Colorado River corridor, Grand Canyon, Ariz., in 2008 and 2009.

51. Temperature, humidity, and barometric pressure data collected at the instrument station AZ C:13:0346 U in the Colorado River corridor, Grand Canyon, Ariz., in 2008 and 2009.

52. Aerial photograph of the area around the instrument station near AZ B:11:0281, in Grand Canyon, Ariz., with arrow indicating net direction of potential aeolian sediment transport measured in 2009.

53. Wind speed and direction measured at the instrument station AZ B:11:0281 in the Colorado River corridor, Grand Canyon, Ariz., in 2009.

54. Cumulative 2009 rainfall record measured at AZ B:11:0281.

55. Wind, rainfall, and aeolian sand-transport data collected at the instrument station AZ B:11:0281, in the Colorado River corridor, Grand Canyon, Ariz., in 2008 and 2009.

56. Temperature, humidity, and barometric pressure data collected at the instrument station AZ B:11:0281 in the Colorado River corridor, Grand Canyon, Ariz., in 2008 and 2009.

57. Aerial photograph of the area around the instrument station near AZ A:15:0033, in Grand Canyon, Ariz., with arrow indicating net direction of potential aeolian sediment transport measured in 2009.

58. Wind speed and direction measured at the instrument station AZ A:15:0033 in the Colorado River corridor, Grand Canyon, Ariz., in 2009.

59. Cumulative 2009 rainfall record measured at AZ A:15:0033.

60. Wind, rainfall, and aeolian sand-transport data collected at the instrument station AZ A:15:0033, in the Colorado River corridor, Grand Canyon, Ariz., in 2008 and 2009.

61. Temperature, humidity, and barometric pressure data collected at the instrument station AZ A:15:0033 in the Colorado River corridor, Grand Canyon, Ariz., in 2008 and 2009.

62. Aerial photograph of the area around the instrument stations near AZ G:03:0072, in Grand Canyon, Ariz., with arrow indicating net direction of potential aeolian sediment transport measured in 2009.

63. Wind speed and direction measured at the instrument station AZ G:03:0072 U in the Colorado River corridor, Grand Canyon, Ariz., in 2009..........................95

64. Cumulative 2009 rainfall record measured at AZ G:03:0072.

65. Wind, rainfall, and aeolian sand-transport data collected at the instrument station AZ G:03:0072 U, and aeolian sand-transport data collected in sand traps at AZ G:03:0072 L, in the Colorado River corridor, Grand Canyon, Ariz., in 2008 and 2009.

66. Temperature, humidity, and barometric pressure data collected at the instrument station AZ G:03:0072 U in the Colorado River corridor, Grand Canyon, Ariz., in 2008 and 2009.

\section{Tables}

1. Details of study sites and equipment deployed at each site...............................23

2. Total rainfall, in $\mathrm{mm}$, received daily at each of the weather stations. ....................24

3. Vector sums of the sediment-transport proxy variable, $Q p$, by month for each weather station. 


\section{Abstract}

This report presents measurements of weather parameters and aeolian sand transport made in 2009 near selected archeological sites in the Colorado River corridor through Grand Canyon, Ariz. The quantitative methods and data discussed here form a basis for monitoring ecosystem processes that affect archeological-site stability. Combined with forthcoming work to evaluate landscape evolution at nearby archeological sites, these data can be used to document the relation between physical processes, including weather and aeolian sand transport, and their effects on the physical integrity of archeological sites. Data collected in 2009 reveal event- and seasonal-scale variations in rainfall, wind, temperature, humidity, and barometric pressure. Broad seasonal changes in aeolian sediment flux are also apparent at most study sites. Differences in weather patterns between 2008 and 2009 included an earlier spring windy season, greater spring precipitation even though 2009 annual rainfall totals were in general substantially lower than in 2008, and earlier onset of the reduced diurnal barometric-pressure fluctuations commonly associated with summer monsoon conditions. Weather patterns in middle to late 2009 were apparently affected by a transition of the ENSO cycle from a neutral phase to the El Niño phase.

The continuation of monitoring that began in 2007, and installation of additional equipment at several new sites in early 2008, allowed evaluation of the effects of the March 2008 high-flow experiment (HFE) on aeolian sand transport. As reported earlier, at 2 of the 9 sites studied, spring and summer winds in 2008 reworked the HFE sandbars to form new aeolian dunes, where sand moved inland toward larger, well-established dune fields. Observations in 2009 showed that farther inland migration of the dune at one of those two sites is likely inhibited by vegetation. At the other location, the new aeolian dune form was found to have moved $10 \mathrm{~m}$ inland toward older, well-established dunes during 2009, resulting in landward transport of several hundred cubic meters of new sand upslope and above the elevation reached by the peak HFE water level.

\section{Introduction}

This report summarizes high-resolution measurements of wind speed and direction, rainfall, air temperature, barometric pressure, and relative humidity made during 2009 at weather stations operated by the Grand Canyon Monitoring and Research Center within the Colorado River corridor through Grand Canyon, Ariz. Sand traps deployed near each weather station collect aeolian (windblown) sand, from which daily sand-transport rates are estimated. These stations provide the only meteorological record available from the interior of Grand Canyon, apart from daily temperature and rainfall measurements made by the National Park Service (NPS) at Phantom Ranch, near river mile 88, and rainfall measurements recorded near river miles 60 and 225 by researchers from Utah State University in 2006 and 2007. ${ }^{1}$

During March 6-9, 2008, a High Flow Experiment (HFE) occurred in Grand Canyon, involving a 60 -hour release of $1,161 \mathrm{~m}^{3} / \mathrm{s}\left(41,000 \mathrm{ft}^{3} / \mathrm{s}\right)$ from Glen Canyon Dam

\footnotetext{
${ }^{1}$ Locations in the river corridor are commonly referred to by their distance, in miles, downstream from Lees Ferry, Ariz. (fig. 1). This report follows that convention and uses SI units for other measurements. River miles used here are those provided by the World Wide Web map server operated by the Grand Canyon Monitoring and Research Center (GCMRC): http://www.gcmrc.gov/products/ims/ims.htm, accessed January 30, 2010. However, in keeping with the legal requirement for federal agencies not to disclose sensitive archaeological site locations, river miles cited in this report are approximate.
} 
that was intended to rebuild sandbars in the Colorado River corridor. This was the third such experimental flow; the earlier two occurred in March 1996 (Webb and others, 1999) and November 2004 (Topping and others, 2006). Some of the sandbars rebuilt by the HFEs are source areas from which windblown sand moves inland to replenish aeolian sand dunes. Aeolian movement of sand following HFEs is important because some dune fields in Grand Canyon contain archeological sites that depend on windblown sand cover for erosional protection (Neal and others, 2000; Thompson and Potochnik, 2000; Draut and others, 2008). Local effects of the March 2008 HFE at the study sites monitored by this project were discussed by Draut and others (2009b), and are updated in this report to include changes observed in HFE-deposited sandbars and, at two sites, in aeolian dunes that formed from those sandbars, during 2009. A more detailed discussion of the 2004 and 2008 HFEs' effects on aeolian sand in the Colorado River corridor through Grand Canyon, and associated management implications, can be found in Draut and Rubin (2008) and Draut and others, 2010.

This report follows Draut and Rubin (2008) in referring to aeolian sand deposits as belonging to one of two types-modern fluvial sourced (MFS) and relict fluvial sourced (RFS) deposits. The two types of aeolian deposits are distinguishable by their position relative to modern fluvial sandbars (those that formed at river flows of 1,270 $\mathrm{m}^{3} / \mathrm{s}$ or less) that could have provided windblown sand for their formation. MFS dune fields are situated directly downwind of active (postdam) fluvial sandbars and formed as the wind moved sand inland from those sandbars, creating dune fields. RFS deposits, in contrast, formed as wind reworked sediment from older (predam), higher-elevation flood deposits, forming aeolian sand dunes from sediment left by floods that were larger than any postdam floods have been. At times, RFS dunes may receive some sand from modern sandbars under certain wind directions; however, their major source of sand is older deposits left by floods greater than $1,270 \mathrm{~m}^{3} / \mathrm{s}$.

\section{Project Objectives}

The primary objective of the cultural resource research and development monitoring project is to develop objective, replicable, and quantitative methods for monitoring ecosystem processes affecting archeological-site stability in the Colorado River corridor in Grand Canyon, Ariz. This monitoring effort documents the relation between physical landscape processes, including weather and aeolian sediment transport, and the physical integrity of archeological sites. Objectives specific to the weathermonitoring component of this project include (1) evaluating the utility and practicality of employing Vaisala transmitters for high-resolution monitoring of local weather conditions in the remote, logistically challenging environment of inner Grand Canyon, (2) evaluating the spatial and temporal variability of weather parameters at select sites distributed throughout the Colorado River corridor in Grand Canyon, and (3) evaluating the effects of weather and sediment transport on the physical condition of archaeological sites there. A further objective, (4), specific to the work conducted in 2008 and 2009, involved applying methods from the cultural monitoring research and development project to evaluate the effects of the experimental high-flow release from Glen Canyon Dam on downstream resources (sandbars, aeolian dunes, and archeologically sensitive areas). In particular, we wanted to determine whether an increase in the size of sandbars as a result of the March 2008 HFE would, under dry and windy weather conditions, result in increased sediment transport and sand cover at nearby archaeological sites. This report concentrates primarily on reporting results related to objective 2 . Objective 1 was addressed in a previous publication (Draut and others, 2009a). While objective 4 was also 
addressed previously by Draut and others (2009b), it is revisited in this report to discuss continuing evolution of fluvial and aeolian sand deposits that formed or enlarged as a result of the March 2008 HFE. Objective 3 was partially addressed in a study by Collins and others (2009) and is the subject of continuing research. The physical processes represented by data collected in this study include seasonal weather cycles (of wind intensity, humidity, barometric pressure, and precipitation patterns) and individual storm events. The rainfall and aeolian sand-transport rates measured in 2009 are reported here and will be used in the future to evaluate processes responsible for landscape change observed at nearby archaeological sites using terrestrial lidar and total-station surveys (for example, Collins and Kayen, 2006; Collins and others, 2008, 2009).

High-resolution weather data, when combined with high-resolution topographic surveys, form one basis to assess potential or measured effects of Glen Canyon Dam operations on archaeological sites in the Colorado River corridor (Fairley and Sondossi, 2008). Data presented in this report provide a basis for comparison with aeolian sandtransport regimes measured at some of the same sites in years preceding the March 2008 HFE. These results will help to address the question of whether, and under what specific weather conditions, enlarging fluvial sandbars (by high-flow dam operations) increases the amount of sand moved inland by wind toward dunes and archeological sites. Additionally, when compiled into decadal-scale records, weather data such as these can be used to identify regional climatic trends. Given that in recent years the Colorado River basin has experienced more warming than other areas of the United States (Saunders and others, 2008), records such as these should prove valuable to a range of ecosystem studies.

\section{Methods}

Since early 2007, instrument stations have operated near seven archeological sites in the Colorado River corridor indicated on figure 1: AZ C:05:0031, AZ C:13:0006, AZ C:13:0336, AZ C:13:0346, AZ B:11:0281, AZ A;15:0033, and AZ G:03:0072. In

February 2008, two additional instrument stations were deployed near AZ C:13:0365 (AZ $\mathrm{C}: 13: 0365 \mathrm{~L}$ and $\mathrm{U})$, and new sand traps were deployed near AZ C:13:0321 and AZ C:13:0336 (AZ C:13:0336 L) in order to collect data relevant to the March 2008 HFE. All of these instrument stations were operating throughout 2009. Each "instrument station" consists of one weather station and one set of sand traps (specifications are discussed below). At AZ C:05:0031, AZ C:13:0365, and AZ C:13:0346, two independent instrument stations operate approximately $80 \mathrm{~m}$ apart from each other, in order to resolve differences in weather and aeolian sand transport that occur at varying elevation and distance from the river. At both AZ C:13:0336 and AZ G:03:0072, an additional set of sand traps is present approximately $40 \mathrm{~m}$ closer to the river than the full instrument station. Table 1 lists the locations of the study sites by approximate river mile, the equipment that operated at each site in 2009, names used for each station in this report, and the general setting of each dune field (whether MFS, RFS, or other type).

Study sites were chosen to provide data relevant to the condition and stability of nearby archeological sites where topographic surveys were conducted (Collins and others, 2008, 2009; O'Brien and Pederson, 2008). Instrument stations were deployed in the vicinity of archeological sites but not near enough to disturb any cultural features or artifacts; sites were selected and equipment installed in collaboration with NPS archeologists. Several of the study sites were chosen because of their apparent responsiveness to experimental sandbar-building flows in 1996 and 2004 (Draut and Rubin, 2006). These sites were retained for the present study in order to extend weather 
records at these locations and to be able to compare results from previous experimental flows with the March 2008 HFE. Sites were distributed along the river corridor between upper Marble Canyon (approximately river mile 25) and the western canyon (approximately river mile 225) in order to record spatial variations in weather patterns throughout the river corridor.

At five of the study sites upstream of river mile 70 (AZ C:05:0031, AZ C:13:0365, AZ C:13:0006, AZ C:13:0336, and AZ C:13:0321), dimensions of river-level sandbars nearest to the instrument stations were surveyed several weeks before and several weeks after the March HFE to evaluate area and volume changes caused by the high flow. Survey methods used were the same as those described by Hazel and others (2008a). Sandbar topography was surveyed before and after the HFE at these same sites, and again during 2009 as reported here, to determine whether sand derived from sandbars moved inland toward areas containing archeological sites. Of the four study sites not surveyed, one does not have a nearby sandbar under the modern dam-controlled flow regime (AZ C:13:0346). The others can have ephemeral sandbars nearby, but owing to time and funding constraints, they were not surveyed before the $2008 \mathrm{HFE}$ (AZ B:11:0281, AZ B:15:0033, and AZ G:03:0072).

\section{Monitoring Weather Parameters}

Specifications of the weather stations were established and fine-tuned during 2007; details of equipment design and modifications made for use in Grand Canyon were discussed by Draut and others (2009a). All weather stations used for this study are configured identically and consist of a transmitter and data logger mounted on a tripod (fig. 2). The transmitter, a Vaisala ${ }^{\mathrm{TM}}$ multi-parameter weather transmitter, model WXT510/520 with serial data interface SDI-12, is mounted at a height of $2 \mathrm{~m}$ above ground level. The data logger is a Nexsens ${ }^{\mathrm{TM}}$ iSIC logger upgraded to $2 \mathrm{MB}$ memory. The system is powered by an Optima D34/78 deep-cycle $12 \mathrm{~V}$ battery (AGM type, 55 Ah) housed in a box on the ground and charged by a south-facing 30-watt, 12 VDC solar panel mounted on the tripod. Solar panels are the BPSX30U model made by BP Solar, modulated by a SK-6 Morningstar Solar 12 VDC, 6A controller.

The manufacturer's stated measurement range for wind speed measured by the Vaisala WXT510/520 transmitter is $0-60 \mathrm{~m} / \mathrm{s}$, with an accuracy of $\pm 0.3 \mathrm{~m} / \mathrm{s}$ or \pm 3 percent whichever is greater, for wind speeds of $0-35 \mathrm{~m} / \mathrm{s}$. For wind speeds of $36-60 \mathrm{~m} / \mathrm{s}$, accuracy is \pm 5 percent. The measurement range for wind direction is $360^{\circ}$, with an accuracy of $\pm 3^{\circ}$. We assume an additional $5^{\circ}$ margin for error incurred by the user when aligning the transmitter with true North, for a total estimated wind-direction accuracy of $\pm 8^{\circ}$. The transmitter has an estimated response time of $250 \mathrm{~ms}$ for detecting wind speed and direction. For this study, wind speed and direction are recorded every 4 minutes, with each data record consisting of the 4-minute averaged wind speed, the 4-minute averaged wind direction, and the speed and direction of the highest gust during each 4-minute interval (gust speed measured as 3-second average). A 4-minute interval was chosen as the highest resolution that can be used given the capacity of memory in the data loggers and the length of time between downloads (often several months).

A pressure sensor on the Vaisala WXT510/520 transmitter detects liquid rainfall with a resolution of $0.01 \mathrm{~mm}$ and 5 percent accuracy according to the manufacturer. Rainfall is recorded on the data logger at 4-minute intervals as a 4-minute total amount. Air temperature, relative humidity, and barometric pressure are recorded by a separate sensor within the shaded housing of the transmitter. Air temperature from -52 to $+60^{\circ} \mathrm{C}$ 
is recorded with an accuracy of $\pm 0.3^{\circ} \mathrm{C}$ at $20^{\circ} \mathrm{C}$. Relative humidity (RH) from 0 to 90 percent is measured with an accuracy of \pm 3 percent, while RH between 90-100 percent is measured with an accuracy of $\mathrm{RH} \pm 5$ percent. The transmitter measures barometric pressure between 600-1,100 mbar with an accuracy of \pm 0.5 mbar at $0-30^{\circ} \mathrm{C}$ and \pm 1 mbar below $0^{\circ} \mathrm{C}$ or above $30^{\circ} \mathrm{C}$. Temperature, relative humidity, and barometric pressure are recorded on the data logger at 4-minute intervals as 4-minute averages.

Weather stations are camouflaged using paint and burlap to reduce their visibility to Grand Canyon National Park visitors. Stations were visited for maintenance and data downloading every 12-18 weeks during 2009, with sand traps having been emptied somewhat more frequently. All transmitters were replaced during 2008 and 2009 and sent to Vaisala for calibration; all were found to have been operating within the manufacturer's stated accuracy ranges during 2009.

\section{Monitoring Aeolian Sediment Transport}

Aeolian sediment transport is monitored at each study site using wedge-shaped, galvanized metal "big spring number eight" (BSNE) passive-sampling sand traps (Fryrear, 1986). Sand traps are emptied during maintenance visits to the instrument stations every 6-18 weeks. Therefore, sediment-transport measurements are based on cumulative values representing the interval between visits. Sediment samples are collected from traps in the field and processed in a laboratory at Northern Arizona University in Flagstaff, Ariz. Organic material is removed from the sediment by treating the samples with hydrogen peroxide. Samples are then dried overnight in an oven at $80^{\circ} \mathrm{C}$, allowed to cool in a desiccant chamber, and weighed on a scale with a precision to $0.0001 \mathrm{~g}$.

This study uses BSNE traps in sets of four deployed on a vertical pole, with the trap orifices set at heights of 0.1, 0.4, 0.7, and $1.0 \mathrm{~m}$ above the ground (fig. 2). Each trap is equipped with a vane that turns the trap into the wind. The BSNE design is used widely in agricultural and geologic studies of windblown sediment, in part because its shape allows it to perform nearly isokinetically, causing minimal distortion of air flow at the sampling orifice (Stout and Fryrear, 1989; Nickling and McKenna Neuman, 1997; Zobeck and others, 2003). The sampling orifice measures $5 \mathrm{~cm}$ tall by $2 \mathrm{~cm}$ wide; air flow enters the trap through the orifice and exits through a 60-mesh screen in the upper surface of the trap. Sediment is retained in the lower half of the trap after falling through a wider (18-mesh) screen. Wind-tunnel studies (Goossens and others, 2000) indicate a BSNE sand-trap efficiency range of 70-130 percent for the wind velocities and sediment grain sizes encountered in Grand Canyon. Efficiency less than 100 percent indicates that air flow is directed away from the orifice, such that the trap undersamples windblown sediment, whereas efficiency greater than 100 percent indicates that air flow is directed into the trap, oversampling windblown sediment. A conservative efficiency range of 70130 percent was used to estimate error in the sand-transport data reported here because it is the best available for this type of bulk sand-transport data. The exact correspondence between wind velocities and local sand-transport rates is unknown.

To represent the sand-transport potential for a given wind velocity, as in previous reports from these instrument stations (Draut and others, 2009a, b), a proxy variable, $Q p$, was used, which is defined as

$$
Q p=\left(u-u_{\text {crit }}\right)^{3}
$$


The relation in equation 1 follows the convention used to construct aeoliansediment-transport models, such as those of Kawamura (1951) and Lettau and Lettau (1977) but substitutes wind velocity for shear velocity. Although the units of $Q p\left(\mathrm{~m}^{3} / \mathrm{s}^{3}\right)$ do not translate directly to a sand flux, the $Q p$ value for each site over a given time interval serves as a proxy indicating potential for sand transport. $Q p$ was calculated for all the data points at which the wind velocity $(u)$ exceeded the critical threshold of motion $\left(u_{\text {crit }}\right)$. The critical threshold of motion is assumed to be $2 \mathrm{~m} / \mathrm{s}$ based on measured sediment grain size at these study sites and other surficial sediment deposits in Grand Canyon (Bagnold, 1941; Draut and Rubin, 2005, 2008). For the data points at which $u<u_{\text {crit }}, Q p$ was set equal to zero, indicating that no sand transport would occur. Dominant wind directions causing sand transport were then calculated by using vector sums of $Q p$ and their associated wind directions from the 4-minute wind measurements. Vector-sum calculations were also made after eliminating the 48 hours of wind measurements recorded after each rainfall event, the amount of time (based on field observations at different times of year) after which sand is generally sufficiently dry to be mobilized by wind.

\section{Results}

Weather and aeolian sand-transport data from each station are discussed in detail below. Table 2 shows daily rainfall recorded at each weather station during 2009. Monthly vector sums of aeolian sand-transport potential at each station are shown in table 3. $Q p$ vector sums for dry conditions are shown in table $3 B$.

\section{Site-Specific Data}

The following sections describe the setting of each weather station, any problems with instrument performance, and site-specific findings from 2009. The station numbers reference nearby archeological sites and are presented in geographic order, starting with the farthest upstream station and proceeding downstream.

\section{AZ C:05:0031}

Two weather stations operated throughout 2009 in an aeolian dune field on the downstream side of a debris fan at the AZ C:05:0031 site-one near river level (AZ $\mathrm{C}: 05: 0031 \mathrm{~L})$ and one at the upper end of the dune field (AZ C:05:0031 U). Neither weather station experienced equipment malfunctions in 2009, although one of the sand traps at station AZ C:05:0031 L broke in July 2009 and was not replaced until October 2009 , resulting in no sand-transport data being collected at that station between July and October.

A fluvial sand deposit occurs at the riverward (western) side of this dune field. The fluvial sandbar area increased 1 percent and its volume increased 8 percent as a result of the March 2008 HFE; during daily flow fluctuations between March and October 2008, the sandbar at this site lost 33 percent of its area and 6 percent of its volume, thus making the sandbar near AZ C:05:0031 smaller in fall 2008 than it was before the HFE (Draut and others, 2009b). Photographs and topographic profiles of the sandbar show that as of the summer and fall of 2009, it continued to erode, losing essentially all of the new sand gained in the 2008 high flow ( $4 \mathrm{~m}$ of shoreward bank retreat since March 2008; figs. 3, 4). 
The dune field between the two weather stations at AZ C:05:0031 undergoes active sand transport and has moderate vegetation and little biologic soil crust (vegetation and biologic crust were quantified at each study site in 2009 , data that will be presented in a separate, forthcoming report). An approximately equal area at the north (upstream) end of the dune field is relatively inactive, with well-developed soil crust and evident deflation of the land surface. Draut and Rubin (2008) identified this dune field as a modern fluvial sourced (MFS) aeolian sediment deposit, based on observations between 2003 and 2006 of net sediment-transport potential from the direction of a river-level sandbar. However, some of the sand in this area was apparently deposited by predam floods and by exceptionally high postdam flows in 1983-1984, based on its topographic position relative to modeled water surface elevations (Magirl and others, 2008) and the presence of a penny, dated 1981, found embedded in a fluvial deposit a short distance upstream of the weather station AZ C:05:0031 L. A vector sum of all available wind data from AZ C:05:0031 L in 2009 yields a net $Q p$ magnitude of $29,658 \mathrm{~m}^{3} / \mathrm{s}^{3}$ from a direction of $206^{\circ}$; using wind data collected only during periods when the sand is estimated to have been dry, a vector sum yields a net $Q p$ magnitude of $25,391 \mathrm{~m}^{3} / \mathrm{s}^{3}$ from a direction of $215^{\circ}$ (fig. 5). These calculations indicate net sand transport generally upstream, although a directional wind plot shows no strong directional component at AZ C:05:0031 L (fig. $6)$.

The total annual rainfall measured at AZ C:05:0031 L in 2009 was $108.9 \mathrm{~mm}$ (table 2); cumulative rainfall data for this station are shown in figure 7 . All weather parameters and sand transport measured at AZ C:05:0031 L in 2009 are summarized in figures 8 and 9, with 2008 data shown for comparison.

A vector sum of all available wind data from station AZ C:05:0031 U (approximately $80 \mathrm{~m}$ inland and uphill of AZ C:05:0031 L) in 2009 yields a net $Q p$ magnitude of $112,090 \mathrm{~m}^{3} / \mathrm{s}^{3}$ from a direction of $243^{\circ}$; using wind data collected only during periods when the sand is estimated to have been dry, a vector sum yields a net $Q p$ magnitude of $85,405 \mathrm{~m}^{3} / \mathrm{s}^{3}$ from a direction of $243^{\circ}$ (fig. 10). These calculations indicate net sand transport generally inland and upstream with a stronger inland-directed component than was measured at this site in 2008 (net potential sand transport in 2008 was from $215^{\circ}$ at AZ C:05:0031 U; Draut and others, 2009b), although, like the lower station, the directional wind plot (fig. 11) still shows no strong directional component at AZ C:05:0031 U.

Total annual rainfall measured at AZ C:05:0031 U was 101.0 mm (table 2); cumulative rainfall data for this station are shown in figure 12. All weather parameters and sand transport measured at AZ C:05:0031 U in 2009 are summarized in figures 13 and 14, with 2008 data shown for comparison.

As observed previously, wind velocities are typically higher at station AZ $\mathrm{C}: 05: 0031 \mathrm{U}$ than at station AZ C:05:0031 L, which is attributed to lower vegetation densities at the upper site. Aeolian sand-transport rates measured at AZ C:05:0031 U are correspondingly higher also (figs. 8, 13). At both the upper and lower station, the greatest sand-transport rates in 2009 occurred in the spring, which is commonly observed at eastern Grand Canyon sites (Draut and Rubin, 2005, 2006; Draut and others, 2009a, b), although the highest wind speeds in 2009 were observed earlier (March-April) than in past years (in 2008, the windiest season spanned April-June). At both stations, aeolian sand-transport rates were somewhat higher in spring 2009 than in spring 2008-by approximately a factor of two - even given the error margin assigned to these data (figs. $8,13)$. 


\section{AZ C:13:0365}

Two instrument stations, situated in approximately the same locations as those used at this site by Draut and Rubin (2008) when studying the November 2004 HFE, have operated near AZ C:13:0365 since February 2008. The area around AZ C:13:0365 includes an active aeolian dune field on the downstream side of a side canyon and an associated debris fan; sand-transport rates within this dune field were higher than those measured at any other site by Draut and Rubin (2008). Dune morphology at AZ C:13:0365 includes north-facing slip faces, consistent with northward dune migration; this morphology combined with dominantly south-southeast winds identify this site as a modern fluvial sourced (MFS) dune field whose primary sediment source is a fluvial sandbar immediately upwind of the dune field. A second sandbar, across the river and approximately $200 \mathrm{~m}$ downstream, also occasionally provides sediment to the dune field near AZ C:13:0365 (Draut and Rubin, 2008).

The sandbar near AZ C:13:0365 lost 17 percent of its area but gained 14 percent more volume as a result of the March 2008 HFE (fig. 15; Draut and others, 2009b). Throughout the rest of 2008 and into 2009 this sandbar lost volume owing to cutbank collapse during daily flow fluctuations. A new aeolian dune approximately $1 \mathrm{~m}$ high formed on the HFE-deposited sandbar (fig. 16) and migrated approximately $10 \mathrm{~m}$ inland toward the larger aeolian dune field during the summer of 2008 (Draut and others, 2009b). Topographic profiles surveyed at this sandbar and dune in 2009 indicate that, although the aeolian dune crest was still present in fall 2009, it had not moved inland appreciably compared to its position in fall 2008 (fig. 17); inland migration of the new dune crest near river level was likely inhibited by thick and growing vegetation (fig. $16 B$ ). Photographs of the river margin near AZ C:13:0365 show apparently rapid growth of riparian vegetation in 2008 and 2009 (figs. 15, 16), which may have been facilitated by inundation during the 2008 high flow; the new vegetation growth has been especially prolific below the $1,161 \mathrm{~m}^{3} / \mathrm{s}\left(41,000 \mathrm{ft}^{3} / \mathrm{s}\right)$ stage (fig. $\left.15 C\right)$.

A vector sum of all wind data from AZ C:13:0365 L in 2009 yields a net $Q p$ magnitude of $34,830 \mathrm{~m}^{3} / \mathrm{s}^{3}$ from a direction of $142^{\circ}$; using wind data collected only during periods when the sand is estimated to have been dry, a vector sum yields a net $Q p$ magnitude of $37,692 \mathrm{~m}^{3} / \mathrm{s}^{3}$ from a direction of $151^{\circ}$ (fig. 18). These calculations indicate net sand transport toward the north-northwest, although the directional wind plot (fig. 19) shows that substantial transport from the north-northwest can also occur at AZ C:13:0365 L. This is consistent with net potential sand transport measured from 2003 to 2006 and in 2008 at this site (Draut and Rubin, 2008; Draut and others, 2009b).

Total rainfall measured at AZ C:13:0365 L was $271.0 \mathrm{~mm}$; cumulative rainfall during 2009 at this station is plotted in figure 20. All weather parameters and sand transport measured at AZ C:13:0365 L in 2009 are summarized in figures 21 and 22. Sand-transport rates were highest at AZ C:13:0365 L during spring 2009 (fig. 21) and were apparently lower (though within overlap range of the error margin of sand-transport measurements) in spring 2009 compared with spring 2008.

A vector sum of all available wind data from AZ C:13:0365 U (approximately 50 $\mathrm{m}$ inland and uphill of AZ C:13:0365 L) in 2009 yields a net $Q p$ magnitude of 1,072,300 $\mathrm{m}^{3} / \mathrm{s}^{3}$ from a direction of $138^{\circ}$; using wind data collected only when the sand is estimated to have been dry, a vector sum yields a net $Q p$ magnitude of $504,510 \mathrm{~m}^{3} / \mathrm{s}^{3}$ from a direction of $140^{\circ}$ (fig. 23). These calculations indicate net sand transport generally toward upstream, with higher wind speeds and a stronger southeasterly directional component than at the lower-elevation station AZ C:13:0365 L, although strong winds also come 
from the northwest at times (fig. 24). The wind velocities and dominant direction from the southeast at AZ C:13:0365 $\mathrm{U}$ are consistent with wind conditions measured at this site between 2003 and 2006 (Draut and Rubin, 2008) and in 2008 (Draut and others, 2009b), and would move sand inland from the HFE-deposited sandbar into the active MFS dune field.

Total rainfall measured in 2009 was $278.0 \mathrm{~mm}$ at AZ C:13:0365 U; cumulative rainfall at this site is plotted on figure 25 . All weather parameters and sand transport measured at AZ C:13:0365 U in 2009 are summarized in figures 26 and 27. Sandtransport rates measured during the spring windy season at AZ C:14:0365 U in 2009 were approximately twice as high as during spring 2008 (fig. 26), although this comparison is complicated by sand-trap malfunction in early spring 2008 that allowed only minimum transport values to be estimated for that time (Draut and others, 2009b).

\section{AZ C:13:0006}

The instrument station near AZ C:13:0006 is on the upstream side (with respect to the Colorado River) of an ephemeral tributary streambed, on a small debris fan. At the instrument site, aeolian sediment is present but is interspersed with rocks and sparse vegetation; areas of open sediment in the vicinity of the weather station and sand traps are largely covered by well-developed biologic soil crust. The sandbar nearest to AZ C:13:0006 lost more than 12 percent of its area during the March 2008 HFE but gained almost 14 percent more volume; cutbank collapse eroded this sandbar during summer 2008 (Draut and others, 2009b). Ongoing cutbank collapse at that sandbar was observed in the field during summer 2009 but no additional topographic profiles were surveyed.

A vector sum of all wind data from the weather station at AZ C:13:0006 in 2009 yields a net $Q p$ magnitude of $92,109 \mathrm{~m}^{3} / \mathrm{s}^{3}$ from a direction of $125^{\circ}$; using data only from when the sand is estimated to have been dry, a vector sum yields a net $Q p$ magnitude of $64,816 \mathrm{~m}^{3} / \mathrm{s}^{3}$ from a direction of $127^{\circ}$ (fig. 28).

Wind speed and direction measured at AZ C:13:0006 in 2009 are plotted in figure 29. Cumulative rainfall data are shown in figure 30; the 2009 annual rainfall total at this site was $226 \mathrm{~mm}$ (table 2). All weather parameters and sand transport measured at AZ C:13:0006 in 2009 are summarized in figures 31 and 32.

Although wind from other directions is not uncommon around AZ C:13:0006 (fig. 29), net potential sediment transport from the east-southeast was indicated during 2009, similar to conditions measured at this site in 2007 and 2008 (Draut and others, 2009a, b). Net sand transport from the southeast would be consistent with the fluvial sand deposit at the downstream end of the debris fan serving as a possible source of windblown sand (fig. 28); however, sand-transport rates measured in 2008 and 2009 were no higher than in 2007 and, even after the 2008 HFE, remain substantially lower than in more active dune fields such as that at AZ C:13:0365, with the measured daily flux at AZ C:13:0006 consistently less than $0.1 \mathrm{~g} / \mathrm{cm}$ (fig. 31). As discussed by Draut and others (2009b), it is likely that the low sand-transport rates measured at the instrument station (situated approximately $20 \mathrm{~m}$ laterally away from and $5 \mathrm{~m}$ vertically below the archeological site) do not accurately reflect aeolian processes affecting the cultural site. However, in order to avoid disturbing the archeological site, sand traps cannot be deployed directly in the area where Collins and others (2009) used remote-sensing lidar equipment to record aeolian sand deposition at AZ C:13:0006. Therefore, links among HFE sand deposition, aeolian sand transport, and inflation/deflation at the archeological site AZ C:13:0006 may not be characterized accurately using the data collected by this study. 


\section{AZ C:13:0336}

The Palisades area, in eastern Grand Canyon, is characterized by alluvial terraces with local aeolian coppice dunes that are vegetated by grasses and small mesquite trees. The alluvial deposits at Palisades represent multiple episodes of floodplain aggradation by Colorado River floods that predate the completion of Glen Canyon Dam in 1963 (for example, Hereford and others, 1993, 1996; Draut and others, 2008). Aeolian coppice dunes at Palisades were interpreted by Draut and Rubin (2008) as relict fluvial sourced (RFS) aeolian deposits that formed by in-place reworking of ancient flood sediment, rather than having been sourced from river-level sandbars within the normal damcontrolled flow range. Alluvial and aeolian deposits are incised by a major gully network (as much as $2 \mathrm{~m}$ deep and tens of meters wide) that drains to the river (Hereford and others, 1993; Thompson and Potochnik, 2000; Hazel and others, 2008b). Repeated topographic surveys have shown frequent changes in gully geometry at Palisades, including aggradation in its mouth as a result of HFEs in 1996 and 2004 and episodic erosion attributed to rain events (Yeatts, 1996; Hazel and others, 2008b). The sandbar nearest to AZ C:13:0336 increased substantially in area and volume as a result of the March 2008 HFE (Draut and others, 2009b). Although subsequent flow fluctuations caused cutbank retreat that eroded the sandbar through the later part of 2008 (Draut and others, 2009b), by mid-2009 a substantial sandbar was still present and was being colonized by tamarisk and other vegetation (fig. 33).

One weather station and one set of sand traps operate at station AZ C:13:0336 U. Since February 2008, one additional set of sand traps has collected windblown sand at a site referred to as AZ C:13:0336 L, on a cobble bar riverward of AZ C:13:0336 U (fig. 34). The AZ C:13:0336 L study site is approximately $50 \mathrm{~m}$ upstream of where a single set of sand traps was used by Draut and Rubin (2008) to study sand transport near river level following the 2004 HFE.

Wind speed and direction measured at AZ C:13:0336 U in 2009 are plotted in figure 35. Cumulative rainfall data are shown in figure 36. All weather parameters and sand transport measured at AZ C:13:0336 U, and sand transport measured at AZ C:13:0336 L, in 2009 are summarized in figures 37 and 38, with 2008 data shown for comparison.

Net potential sediment transport from the southeast was indicated at AZ C:13:0336 U during 2009 (fig. 34), similar to conditions measured at this site in previous years (Draut and Rubin, 2008; Draut and others, 2009a, b). A vector sum of wind data from the weather station at $\mathrm{AZ} \mathrm{C:13:0336} \mathrm{U}$ in 2009 yields a net $Q p$ magnitude of $757,930 \mathrm{~m}^{3} / \mathrm{s}^{3}$ from a direction of $144^{\circ}$; using wind data collected only when the sand is estimated to have been dry, a vector sum yields a net $Q p$ magnitude of $364,770 \mathrm{~m}^{3} / \mathrm{s}^{3}$ from a direction of $144^{\circ}$ (fig. 34). Therefore, although the sandbar riverward (southwest) of the study sites enlarged substantially during the $2008 \mathrm{HFE}$, the dominant wind direction here would not move sand from the sandbar into the dune field (even though, on occasion, wind does blow from the southwest at this site; fig. 35). Sand-transport rates measured at AZ C:13:0336 U in 2009 were higher than in 2008 but comparable to those measured in 2007 (fig. 37 and Draut and others, 2009a). An episode of high winds in late September and early October 2009 apparently produced sand-transport rates in the fall that were comparable (within error) to those measured during spring 2009 (fig. 37). Sediment-transport rates measured on the cobble bar near river level (AZ C:13:0336 L) were generally less than one-twentieth as great as those within the dune field (AZ C:13:0336 U; fig. 37). 
Annual rainfall at AZ C:13:0336 (table 2, fig. 36) in 2009 was substantially lower, at $212.0 \mathrm{~mm}$, than at weather stations $10-15 \mathrm{~km}$ upstream (such as AZ C:13:0365 L and $\mathrm{U}$, which received 271 and $278 \mathrm{~mm}$ respectively in 2009). This spatial variability in the eastern canyon is consistent with rainfall patterns measured in previous years (Draut and Rubin, 2005, 2006; Draut and others, 2009a, b).

\section{AZ C:13:0321}

One set of BSNE sand traps measures sand-transport rates in a moderately vegetated aeolian sand deposit near river level at AZ C:13:0321. At this site, large (>10 $\mathrm{m}$ high), well established aeolian dunes are present inland from a fluvial sandbar and above the postdam high water level. The orientation of dune slip faces indicates migration toward the northeast (inland), suggesting that this site is most likely an MFS aeolian deposit downwind of an active, modern sandbar.

The sandbar near AZ C:13:0321 increased substantially in area and volume owing to sediment deposition from the March 2008 HFE (Draut and others, 2009b). Although some sand was eroded by daily flow fluctuations, forming a cutbank in the new sandbar, in the summer of 2008, wind had reworked sand from the HFE sandbar to form a new aeolian dune more than $1 \mathrm{~m}$ high (fig. 39; Draut and others, 2009b). The shape and slipface orientation of the new dune face indicated that it has migrated (and moved sand) inland, toward the larger, well established dune field. When surveyed in October 2008, the new dune was taller (by $1.5 \mathrm{~m}$ ) than the surface of the sandbar deposited by the HFE, and its crest was approximately $1 \mathrm{~m}$ higher than the maximum elevation reached by the HFE water. A topographic survey completed a year later in October 2009 indicated that the dune crest had continued to maintain similar shape and had migrated approximately $10 \mathrm{~m}$ inland, advancing farther toward the large aeolian dunes near AZ C:13:0321 (fig. 40).

Daily sand flux measured near AZ C:13:0321 during 2009 was similar to that measured at the site in 2008, at $1-3 \mathrm{~g} / \mathrm{cm}$ (fig. 41). Although wind conditions were not measured directly at AZ C:13:0321, the dune migration direction indicates a dominant sand-transport direction from southwest toward northeast (sand moving inland). This is consistent with net sediment-transport directions derived from wind measurements at the nearest weather stations (at AZ C:13:0346, discussed below), which are situated $700 \mathrm{~m}$ away from AZ C:13:0321 (fig. 42).

\section{AZ C:13:0346}

Two instrument stations operated in 2009 near river mile 70, AZ C:13:0346 L and AZ C:13:0346 U. This reach of the Colorado River corridor in eastern Grand Canyon is several kilometers wide, is characterized by broad meander bends in the river, and is part of the geomorphic region referred to as the Furnace Flats reach by Schmidt and Graf (1987). It is not known whether sandbars in the vicinity of AZ C:13:0346 grew substantially as a result of the 2008 HFE. In general the dune field at this site is bordered by riparian vegetation and not by sandbars (fig. 42); therefore, it is not surprising that no effects of the 2008 HFE were detected in the vicinity of these two instrument stations.

The station AZ C:13:0346 L is situated within an active dune field that has well developed dune forms and active sediment transport. In 2009, it was observed that vegetation cover in this dune field is increasing, owing to rapid spread of Russian thistle 
(Salsola tragus, a nonnative species). This will be investigated further in 2010, with efforts made to match photographs from specific locations taken in previous years.

The Nexsens data logger at AZ C:13:0346 L ceased collecting data on May 17, 2009. The equipment failure was identified during a site visit in July, and the data logger was replaced during the next site visit in October, with data collection then resuming on October 17, 2009. After that date, weather data were collected for the remainder of the year without interruption.

Wind speed and direction measured at AZ C:13:0346 L in 2009 are plotted in figure 43. Cumulative rainfall data are shown in figure 44; total rainfall measured at that station in 2009, excluding the interval between May 17 and October 17 when the station was not operating, was $75.9 \mathrm{~mm}$. All weather parameters and sand transport measured at AZ C:13:0346 L in 2009 are summarized in figures 45 and 46, with 2008 data shown for comparison.

A vector sum of wind data from the weather station at AZ C:13:0346 L between January 1 and May 17 and between October 17 and December 31, 2009, yields a net $Q p$ magnitude of $476,470 \mathrm{~m}^{3} / \mathrm{s}^{3}$ from a direction of $244^{\circ}$; using wind data collected from the same time interval only when the sand is estimated to have been dry, a vector sum yields a net $Q p$ magnitude of $170,460 \mathrm{~m}^{3} / \mathrm{s}^{3}$ from a direction of $228^{\circ}$ (fig. 42). These net potential sand-transport directions reflect a fairly strong directional component from the west-southwest (fig. 43). Daily sand-transport rates at AZ C:13:0346 L were highest in late winter and early spring, as at other stations, and were comparable in magnitude to those in spring 2008 (fig. 45).

Station AZ C:13:0346 U is situated upstream of AZ C:13:0346 L and slightly farther inland from the river (fig. 47). The land surface in the vicinity of station AZ $\mathrm{C}: 13: 0346 \mathrm{U}$ includes relatively inactive dunes on a broad, flat landscape with abundant silty material, some derived from relict fluvial deposits and some comprising distal slopewash from local bedrock. Biologic soil crust is more abundant around AZ C:13:0346 U than around AZ C:13:0346 L; this was quantified during field work in 2009 and will be discussed in a separate, forthcoming report. Wind speed and direction measured at AZ $\mathrm{C}: 13: 0346 \mathrm{U}$ in 2009 are plotted in figure 48. Cumulative rainfall data are shown in figure 49; total rainfall measured in 2009 was $193.8 \mathrm{~mm}$. All weather parameters and sand transport measured at AZ C:13:0346 U in 2009 are summarized in figures 50 and 51, with 2008 data shown for comparison.

A vector sum of all available wind data from AZ C:13:0346 U in 2009 yields a net $Q p$ magnitude of $558,440 \mathrm{~m}^{3} / \mathrm{s}^{3}$ from a direction of $233^{\circ}$; using wind data collected only when the sand is estimated to have been dry, a vector sum yields a net $Q p$ magnitude of $369,050 \mathrm{~m}^{3} / \mathrm{s}^{3}$ from a direction of $237^{\circ}$ (fig. 47). These net potential sand-transport directions reflect a consistent directional component from the west-southwest (fig. 48). Aeolian sediment-transport rates at AZ C:13:0346 U were, in general, approximately one tenth of those measured at AZ C:13:0346 L (figs. 45, 50). Similar difference in sand-transport rates between these two stations occurred in 2007 and 2008. The difference is likely caused primarily by more extensive biologic soil crust around station AZ C:13:0346 U inhibiting entrainment and transport of sand by wind (Leys and Eldridge, 1998; Belnap, 2003; Goossens, 2004), because wind velocities were comparable at the two stations, at least for the part of 2009 during which the data logger at AZ C:13:0346 was working. Station AZ C:13:0346 U showed slightly higher sandtransport rates in spring 2009 compared to spring 2008 (fig. 50). 


\section{AZ B:11:0281}

One instrument station operated near AZ B:11:0281 throughout 2009 with no interruptions. This station is situated on the upstream side of a small debris fan that formed at the mouth of an ephemeral tributary drainage (fig. 52). The land surface at this site consists of moderately active aeolian dunes with moderate vegetation cover and biologic soil crust. Inland from the river on its south side, fine-grained sedimentary deposits occur near AZ B:11:0281 that are thought to have settled out of suspension as the river flow ponded behind a large landslide deposit (Huntoon, 2003) that temporarily dammed the river $3 \mathrm{~km}$ downstream around $20 \mathrm{ka}$ (R.H. Webb, written comm., 2008). Sandbars $400 \mathrm{~m}$ upstream and $200 \mathrm{~m}$ downstream of AZ B:11:0281 received new fluvial sand as a result of the 2008 HFE, according to qualitative observations by river runners who utilized the new sandbars as camping beaches after the high flow, but those sand deposits were neither photographed nor surveyed by science parties. Because those new sand deposits are not upwind of the instrument station, the $2008 \mathrm{HFE}$ is not considered to have affected aeolian sand transport substantially in the area around station AZ B:11:0281.

Wind speed and direction measured at AZ B:11:0281 in 2009 are plotted in figure 53. Cumulative rainfall data are shown in figure 54; total rainfall measured in 2009 was $217.2 \mathrm{~mm}$. All weather parameters and sand transport measured at AZ B:11:0281 in 2009 are summarized in figures 55 and 56, with 2008 data shown for comparison.

A vector sum of all wind data from AZ B:11:0281 in 2009 yields a net $Q p$ magnitude of $154,970 \mathrm{~m}^{3} / \mathrm{s}^{3}$ from a direction of $91^{\circ}$; using wind data collected only when the sand is estimated to have been dry, a vector sum yields a net $Q p$ magnitude of $125,790 \mathrm{~m}^{3} / \mathrm{s}^{3}$ from a direction of $97^{\circ}$ (fig. 52). These net potential sand-transport directions reflect a consistent directional component from the east-southeast (fig. 53). Sand transport around AZ B:11:0281 showed only a marginal increase during the spring windy season of 2009, even though wind speed was generally higher then than in other seasons. Daily sand-transport rates remained below $0.1 \mathrm{~g} / \mathrm{cm}$ for most of the year, similar to rates measured in 2008 but less than a third of the rates that were measured at the site during spring 2007 (fig. 55 and Draut and others, 2009a). Low sand-transport rates at this site may be attributed to vegetation upwind (east) of the sand traps that limited sand entrainment, a possibility that will be evaluated further during analysis of vegetation coverage data that were collected in 2009.

\section{AZ A:15:0033}

One instrument station operated near archeological site AZ A:15:0033 in 2009 with no interruptions. The study site includes an aeolian dune field near river level that is covered by moderately dense vegetation (fig. 57). The vegetation has grown on the dune field and on a large river-level sandbar just downstream from the dune field since the 1960s and now covers much of the previously open sand (Draut and Rubin, 2008). Immediately upstream of the weather station, an aeolian dune field shows evidence of deflation, some biologic soil crust, and gully incision. We do not know whether riparian sandbars near this study site increased in area or volume as a result of the March 2008 HFE, because no topographic surveys were conducted in this area. Anecdotal evidence from those who observed this area shortly after the high flow indicates that the HFE did not form substantial new sand deposits near AZ A:15:0033 and, therefore, is not considered to have affected aeolian sand transport near this site. 
Wind speed and direction measured at AZ A:15:0033 in 2009 are plotted in figure 58. Cumulative rainfall data are shown in figure 59; total rainfall measured in 2009 was $184.4 \mathrm{~mm}$. All weather parameters and sand transport measured at A:15:0033 in 2009 are summarized in figures 60 and 61, with 2008 data shown for comparison.

Wind conditions measured at station AZ A:15:0033 in past years $(2004,2005$, 2007, and 2008) have been complex; although upstream and downstream winds nearly balanced each other, vector components from the northeast can result in net potential sand flux toward the river (Draut and Rubin, 2006, 2008). A vector sum of all wind data from AZ A:15:0033 in 2009 yields a net $Q p$ magnitude of $16,941 \mathrm{~m}^{3} / \mathrm{s}^{3}$ from a direction of $221^{\circ}$; using wind data only from when the sand is estimated to have been dry, a vector sum yields a net $Q p$ magnitude of $17,280 \mathrm{~m}^{3} / \mathrm{s}^{3}$ from a direction of $225^{\circ}$ (fig. 57). As in past years, these net potential sand-transport directions reflect a balance between upstream and downstream winds, with the weakly dominant net transport vector from the southwest (figs. 57, 58).

As in past years, daily sand-transport rates at AZ A:15:0033 were the lowest measured at any study site in 2009-always below $0.02 \mathrm{~g} / \mathrm{cm}$ even during spring winds when gust speeds exceeded $16 \mathrm{~m} / \mathrm{s}$ (fig. 60). This is attributed to the density of vegetation cover near the instrument station, which effectively inhibits entrainment of sand by decreasing wind velocity near the bed (Bressolier and Thomas, 1977; Buckley, 1987). Sand transport at this site was no higher in the spring than at other times of year in 2007, 2008, or 2009 (fig. 60; Draut and others, 2009a).

\section{AZ G:03:0072}

During 2009, one complete instrument station operated at AZ G:03:0072 (station AZ G:03:0072 U; table 1) along with one additional set of sand traps (station AZ G:03:0072 L); equipment locations are shown in fig. 62. The study sites are situated on sedimentary deposits that cover the downstream part of a debris fan. Station AZ $\mathrm{G}: 03: 0072 \mathrm{U}$ is in an active aeolian dune field that has sparse vegetation and patches of biologic soil crust. The sand traps at AZ G:03:0072 L are lower in elevation and closer to the river than $\mathrm{AZ} \mathrm{G:03:0072} \mathrm{U}$, in an area with some biologic soil crust; moderate to thick vegetation is present between the lower site and the river (fig. 62). All equipment near AZ G:03:0072 operated throughout 2009 with no interruptions. A small new sand deposit formed at the separation bar immediately downstream of AZ G:03:0072 after the March 2008 HFE, but this deposit was not photographed or surveyed; therefore, the effects of the $2008 \mathrm{HFE}$ on sandbar growth or aeolian transport at this site are not known in detail.

Wind speed and direction measured at AZ G:03:0072 U in 2009 are plotted in figure 63. Cumulative rainfall data are shown in figure 64; total rainfall measured in 2009 was $148.3 \mathrm{~mm}$. All weather parameters and sand transport measured at G:03:0072 U in 2009, and sand transport measured at AZ G:03:0072 L, are summarized in figures 65 and 66, with 2008 data shown for comparison.

A vector sum of all available wind data from AZ G:03:0072 U in 2009 yields a net $Q p$ magnitude of $81,429 \mathrm{~m}^{3} / \mathrm{s}^{3}$ from a direction of $176^{\circ}$; using wind data collected only when the sand is estimated to have been dry, a vector sum yields a net $Q p$ magnitude of $65,905 \mathrm{~m}^{3} / \mathrm{s}^{3}$ from a direction of $175^{\circ}$ (fig. 62). This net flux direction toward upstream reflects a balance between upstream and downstream winds rather than one strong upstream-directed velocity component (fig. 63). 
Daily sand-transport rates measured at AZ G:03:0072 L and AZ G:03:0072 U were similar, commonly on the order of $0.1 \mathrm{~g} / \mathrm{cm}$, and, similar to previous years, showed no substantial increase during the spring (fig. 65), which may be attributed to the presence of vegetation limiting wind velocities in the area around both sets of sand traps.

\section{Discussion}

According to the National Climatic Data Center (NCDC), 2009 regional weather conditions in the southwestern U.S. were characterized by above-normal temperatures and abnormally dry weather; Arizona had its $4^{\text {th }}$ driest year in terms of annual precipitation out of the 115 years that records have been kept (NCDC, http://www.ncdc.noaa.gov/). Regional drought monitoring indicated that the southwestern U.S. ranged from abnormally dry to extremely dry between January and December 2009 (NCDC and University of Nebraska, Lincoln, http://drought.unl.edu/dm/monitor.html, last accessed March 12, 2010). The U.S. as a whole, however, received more annual precipitation than the long-term average, with 2009 being the $18^{\text {th }}$ wettest year nationally in 115 years of records.

Conditions of overall drought in the southwestern U.S. during 2009 saw substantial seasonal variations. The winter of 2008-2009 brought near normal precipitation levels to Arizona and much of the southwest. Whereas spring 2009 saw below normal precipitation in Arizona and near normal over the rest of the southwest, the Grand Canyon was wetter in spring 2009 than in spring 2008 (discussed below). Unusually dry conditions were apparent in Arizona beginning in summer; the 2009 summer was Arizona's third driest on record. Much-below-normal precipitation continued into fall 2009, with Arizona experiencing its sixth driest fall season on record. Rainfall records from Grand Canyon in 2009 are consistent with 2009, in general having been substantially drier than 2008; the 2009 annual rainfall totals at weather stations in this study are commonly 55-75 percent of their 2008 annual totals. This decrease in rainfall between 2008 and 2009 was apparent in all regions of Grand Canyon. For example, the weather stations at AZ C:05:0031, in upper Marble Canyon, received around $190 \mathrm{~mm}$ and $105 \mathrm{~mm}$ in 2008 and 2009, respectively; station AZ C:13:0006, near river mile 60, received $329 \mathrm{~mm}$ and $226 \mathrm{~mm}$ in 2008 and 2009, respectively; station AZ B:11:0281, in the central canyon, received $299 \mathrm{~mm}$ and $217 \mathrm{~mm}$ in 2008 and 2009, respectively; station AZ G:03:0072, in the western canyon, received $249 \mathrm{~mm}$ and 148 $\mathrm{mm}$ in 2008 and 2009, respectively (this study and Draut and others, 2009b).

In addition to regional anomalies in the amount of rainfall received, the Grand Canyon weather patterns in 2009 differed from those observed in previous years in the timing of the so-called spring windy season and in the timing of seasonal changes in precipitation and barometric pressure. All stations in this study recorded intensification of wind speed in March and April 2009, reaching diurnal average wind speeds and maximum gust speeds that, in past years, have more commonly characterized April, May, and early June (figs. 8, 13, 21, 26, 31, 37, 45, 50, 55, 60, 65; Draut and Rubin, 2008; Draut and others, 2009a, b). Subsequently, these weather stations recorded more rainfall in spring 2009 in Grand Canyon than in past spring seasons; rain totals for May 2009, for instance, were higher than those for May 2008 at every station except AZ A:15:0033. May 2009 rainfall at the other stations commonly exceeded May 2008 rainfall by factors of 2 to 6. In addition to higher rainfall than in the previous spring, the spring of 2009 was also characterized by diurnal fluctuations in barometric pressure that, in past years, have occurred later in the year associated with summer monsoon conditions. Barometricpressure plots clearly show these differences between 2008 and 2009 (figs. 9, 14, 22, 27, 
$32,38,46,51,56,61,66)$. During the summer monsoon season, which in 2008 lasted from late June to September (year days 180 to 270), intense rain events commonly occur, and daily fluctuations in barometric pressure tend to be low-commonly less than 10 mbar-in response to monsoonal increase in atmospheric moisture and accompanying decrease in diurnal temperature variations. In contrast, weather patterns at other times of year are accompanied by greater diurnal barometric-pressure variations (20 mbar or more). Barometric-pressure patterns in 2009 showed the switch from greater (commonly $\geq 20$ mbar) to smaller ( $\leq 10$ mbar) diurnal pressure fluctuations beginning in late April, around year day 115 (nearly two months earlier than in 2008), conditions which persisted into September 2009 (around year day 270).

Differences in seasonal (monsoonal) barometric pressure and precipitation patterns between 2008 and 2009 were likely caused by changes in sea-surfacetemperature patterns in the Gulf of California, probably in turn related to the El Niño/Southern Oscillation (ENSO) cycle. ENSO conditions spent much of 2008 in a La Niña (cool) mode, transitioning to a neutral phase by the end of 2008 (http://www.ncdc.noaa.gov/oa/climate/research/enso/, last accessed March 12, 2010). By May 2009, ENSO-neutral conditions across the equatorial Pacific Ocean began to give way to weaker wind patterns and warm sea-surface-temperature anomalies associated with entering an El Niño (warm) phase of the ENSO cycle, which was definitively established by June 2009. The El Niño event strengthened through July and August, defining a weak to moderate El Niño phase that persisted for the remainder of 2009, and intensified by early 2010 to be classified as moderate to strong El Niño conditions (NOAA Climate Prediction Center, ENSO Diagnostic Discussion, http://www.cpc.noaa.gov/products/analysis_monitoring/enso_advisory/ensodisc.html, last accessed March 12, 2010). Although a detailed analysis of the effects of the ENSO cycle on Grand Canyon weather patterns is beyond the scope of this report, the known effects of El Niño events on atmospheric circulation and associated weather over the southwestern U.S. suggest that differences between 2008 and 2009 weather documented by this study may have been influenced by warmer temperatures in the Gulf of California that were associated with ENSO conditions. Development of the summer monsoon in Arizona requires atmospheric moisture that moves north from the Gulf of California when sea-surface temperatures there are sufficiently warm (Mitchell and others, 2002). In 2009, sea-surface temperatures were anomalously warm in the Gulf of California as early as May, in contrast to average to abnormally cool conditions in spring 2008 (http://www.ncdc.noaa.gov/teleconnections/enso/indicators/sea-tempanom.php?begmonth=1\&begday=1\&begyear=2008\&endmonth=8\&endday $=18 \&$ endyear =2010\&submitted=Animate+Selection last accessed June 8, 2010. We infer that earlier warming of the Gulf of California in 2009, likely associated with the advancing El Niño conditions that year, led to the earlier rainfall and barometric-pressure (atmospheric moisture) changes observed in Grand Canyon. We expect that conditions measured at these weather stations through the winter of 2009-2010 will provide a valuable data set for measuring the effects of El Niño conditions on local and regional weather in the Grand Canyon area that data can be contrasted with 2007-2008 data collected during the La Niña phase of the ENSO cycle. 
Similar to conditions measured in previous years in the Colorado River corridor through Grand Canyon, rainfall in 2009 was spatially variable among the study sites. As in past years (Draut and Rubin, 2008; Draut and others, 2009a, b), the greatest rainfall amounts were measured in eastern Grand Canyon near river mile 60, where event-based and annual total rainfall are commonly as much as twice as great as a short distance downstream near river miles 65-70 (table 2). This spatial difference occurs both during individual storms and over the year as a whole and is attributed to local topographic effects of the Walhalla Plateau, which rises above the western rim (North Rim) of the canyon near river miles 57-64.

Considering equipment operation, we found 2009 the most successful year of the three in which the current system of weather stations, data loggers, and power supplies have been in operation; relatively few instruments malfunctioned compared to 2008, which in turn saw fewer equipment failures than in 2007. The only station that had an equipment failure in 2009 (AZ C:13:0346 L) was repaired in October 2009 and functioned normally thereafter. In 2008, two dune fields near river miles 60 and 70 experienced apparently abundant active aeolian sand transport that may reflect the Vaisala sensors' inability to distinguish between the impact of raindrops and windblown sediment particles, and that caused rainfall readings to be erroneously high at two of the study sites (AZ C:13:0365 U and AZ C:13:0346 L), especially during spring, when wind velocities are commonly highest. Similar situations were not observed at these two sites in spring 2009, and rainfall readings from the two sets of weather stations at each of those sites were similar, indicating that this may not be a substantial cause for concern, at least not under the wind and sand-transport conditions experienced in spring 2009.

\section{Continued Monitoring of the Effects of the March 2008 High-Flow Experiment}

In general, investigations of the Glen Canyon Dam high-flow experiments (HFEs) that occurred in 2004 and 2008 have shown that, under sufficiently sand-enriched conditions in the mainstem river channel, HFEs can create new sandbars and enlarge existing ones; this was observed at the five sites studied for this project where sandbar area and volume were quantified (Draut and others, 2009b). Unlike sandbars formed by the November 2004 HFE, from which sand rapidly eroded owing to high fluctuating flows (Draut and Rubin, 2008), the 2008 HFE sandbars were present during spring months, the season when windblown sand transport is generally greatest in Grand Canyon. Topographic surveys showed that, after having gained sand volume as a result of the March 2008 HFE, sandbars then lost sand volume between March and October 2008, losses that generally continued during 2009. This was largely attributed to cutbank erosion resulting from summer daily flow fluctuations (Hazel and others, 2010), which were generally $340-509 \mathrm{~m}^{3} / \mathrm{s}\left(12,000-18,000 \mathrm{ft}^{3} / \mathrm{s}\right)$, although some volume loss could also have occurred by wind deflation; where surveyed, sandbar profiles showed evidence of both processes (figs. 17, 40).

At 2 of the 9 sites studied for this project (AZ C:13:0321 and AZ C:13:0365), winds in spring and summer 2008 were found to have reworked HFE-deposited sandbars to form new aeolian dunes, which moved sand inland toward larger, well established dune fields. At the other 7 study sites, new aeolian dunes were not observed, and sandtransport rates after the 2008 HFE were comparable to or lower than in previous years. At 
AZ C:05:0031 and AZ B:11:0281, dominant wind directions relative to sandbar locations were such that little HFE sand would have moved inland; at AZ C:13:0336, AZ

C:13:0346, and AZ A:15:0033, no HFE effects were anticipated owing to lack of sandbar enlargement upwind of the study sites (at these sites, aeolian dunes are relict-fluvialsourced [RFS] sedimentary deposits, the sand sources of which occur at too high an elevation to have been replenished by the March 2008 HFE). At AZ C:13:0006 and AZ G:03:0072, new sand movement to the sites was likely limited by small sandbar size or short lifespan before being eroded by the river, as well as by blocking effects of vegetation or local topography. Because the effects of the 2008 HFE on all of these study sites were discussed in detail by Draut and others (2009b), this discussion of HFE effects focuses on the evolution during 2009 of the aeolian dunes at AZ C:13:0321 and AZ C:13:0365 that formed from new HFE sand.

At AZ C:13:0321 and AZ C:13:0365, aeolian dunes that had formed by wind reworking of March 2008 HFE sand were still readily apparent in 2009 (figs. 16, 17, 39, 40). The shape and orientation of the dunes in both cases indicated continued sand movement inland toward larger, well established dune fields. At AZ C:13:0365, the new aeolian dune had formed in an area where vegetation grew rapidly in 2008 and 2009 near river level, and it is likely that landward migration of the dune was inhibited by vegetation; the crest of the new dune had not moved appreciably when re-surveyed in October 2009, even though wind conditions during 2009 would have been conducive to landward (northwestward) sand transport there. At AZ C:13:0321, a topographic survey in October 2009 indicated landward migration of the new aeolian dune crest by $10 \mathrm{~m}$ since the October 2008 survey (fig. 40). Given the cross-sectional area of the dune (approximately $9 \mathrm{~m}^{2}$ ) and its length (approximately $40 \mathrm{~m}$ ), this implies that between October 2008 and October 2009, at least $360 \mathrm{~m}^{3}$ of new sand migrated inland by at least $10 \mathrm{~m}$ at this site. As shown in figure 39, by fall 2009 the entire cross-sectional area of this new dune was situated landward of, upslope of, and at higher elevation than the uppermost limit reached by the HFE water level in March 2008.

\section{Conclusions}

Analysis of weather patterns in the Colorado River corridor through Grand Canyon, Ariz., was facilitated in 2009 by improved equipment performance compared with 2007 and 2008, owing to software and hardware modifications made over the preceding two years. As in past years, seasonal changes in aeolian sand flux were apparent at most study sites, although the resolution of sand-transport variations depends upon the intervals of manual sample collection. Data collected in 2009 also clearly reveal event- and seasonal-scale variations in rainfall, wind, temperature, humidity, and barometric pressure, some of which differed substantially from patterns recorded in 2008 . Most notably, differences between 2008 and 2009 included an earlier spring windy season (March-April 2009 in contrast to April-May 2008), greater spring precipitation even though 2009 annual rainfall totals were in general substantially lower than in 2008 , and earlier onset of the reduced diurnal barometric-pressure fluctuations commonly associated with summer monsoon conditions (which began in late April 2009 in contrast to having begun in mid-June 2008). Weather patterns in middle to late 2009 were affected by a transition of the ENSO cycle from a neutral phase to the El Niño phase.

The quantitative methods and data discussed here form a basis for monitoring ecosystem processes that affect archeological-site stability. Combined with work by other researchers to evaluate landscape evolution at nearby archeological sites, these data can 
be used to document the relation between physical processes, including weather and aeolian sand transport, and the stability of archeological sites.

Monitoring of the effects of the March 2008 high-flow experiment (HFE) release from Glen Canyon Dam continued in 2009, focusing on the evolution of new aeolian dunes that had formed in 2008 by wind reworking of HFE-deposited sandbars at two study sites. At one of those sites, the new dune crest moved little in 2009, apparently inhibited by rapidly growing riparian vegetation. At the other site, where vegetation is less abundant, repeated topographic surveys showed that the new dune crest moved inland $10 \mathrm{~m}$ between fall 2008 and fall 2009, indicating that several hundred $\mathrm{m}^{3}$ of HFEdeposited sand have now moved inland and up-slope, to an elevation above that reached by the HFE flow itself.

\section{Acknowledgments}

This study is supported by funding from the U.S. Bureau of Reclamation, through the Grand Canyon Monitoring and Research Center. Tim Andrews provided valuable help with weather-station maintenance and configuration. The anonymous reviewers are thanked for constructive comments on this report.

\section{References Cited}

Bagnold, R.A., 1941, The physics of blown sand and desert dunes (4th ed.): London, Chapman and Hall, 265 p.

Belnap, J., 2003, Biological soil crusts and wind erosion, in Belnap, J., and Lange, O.L., eds., Biological soil crusts - Structure, function, and management (Ecological Studies series, v. 150): Berlin, Springer-Verlag, p. 339-347.

Bressolier, C., and Thomas, Y.-F., 1977, Studies on wind and plant interactions on French Atlantic coastal dunes: Journal of Sedimentary Petrology, v. 47, p. 331-338.

Buckley, R., 1987, The effect of sparse vegetation on the transport of dune sand by wind: Nature, v. 325, p. 426-428.

Collins, B.D., and Kayen, R., 2006, Applicability of terrestrial LIDAR scanning for scientific studies in Grand Canyon National Park, Arizona: U.S. Geological Survey Open-File Report 2006-1198, 32 p. [http://pubs.usgs.gov/of/2006/1198/].

Collins, B.D., Brown, K.M., and Fairley, H.C., 2008, Evaluation of terrestrial LIDAR for monitoring geomorphic change at archeological sites in Grand Canyon National Park, Arizona: U.S. Geological Survey Open-File Report 2008-1384, 60 p. [http://pubs.usgs.gov/of/2008/1384/].

Collins, B.D., Minasian, D., and Kayen, R., 2009, Topographic change detection at select archeological sites in Grand Canyon National Park, Arizona, 2006-2007: U.S. Geological Survey Scientific Investigations Report 2009-5116, 68 p. [http://pubs.usgs.gov/sir/2009/5116/].

Draut, A.E., Andrews, T., Fairley, H.C., and Brown, C.R., 2009, 2007 weather and aeolian sand-transport data from the Colorado River corridor, Grand Canyon, Arizona: U.S. Geological Survey Open-File Report 2009-1098, 110 p. [http://pubs.usgs.gov/of/2009/1098/]. 
Draut, A.E., Hazel, J.E. Jr., Fairley, H.C., and Brown, C.R., 2010, Aeolian reworking of sandbars from the March 2008 Glen Canyon Dam high flow experiment in Grand Canyon, in Melis, T.S., Hamill, J.F., Coggins, L.G., Jr., Grams, P.E., Kennedy, T.A., Kubly, D.M., and Ralston, B.E., eds., Proceedings of the Colorado River Basin Science and Resource Management Symposium, November 18-20, 2008, Scottsdale, Arizona: U.S. Geological Survey Scientific Investigations Report 20105135, p. 325-331 [http://pubs.usgs.gov/sir/2010/5135/].

Draut, A.E., and Rubin, D.M., 2005, Measurements of wind, aeolian sand transport, and precipitation in the Colorado River corridor, Grand Canyon, Arizona-November 2003 to December 2004: U.S. Geological Survey Open-File Report 2005-1309, 70 p. [http://pubs.usgs.gov/of/2005/1309/].

Draut, A.E., and Rubin, D.M., 2006, Measurements of wind, aeolian sand transport, and precipitation in the Colorado River corridor, Grand Canyon, Arizona-January 2005 to January 2006: U.S. Geological Survey Open-File Report 2006-1188, 88 p. [http://pubs.usgs.gov/of/2006/1188/].

Draut, A.E., and Rubin, D.M., 2008, The role of eolian sediment in the preservation of archeologic sites along the Colorado River corridor in Grand Canyon National Park, Arizona: U.S. Geological Survey Professional Paper 1756 [http://pubs.usgs.gov/pp/1756/].

Draut, A.E., Rubin, D.M., Dierker, J.L., Fairley, H.C., Griffiths, R.E., Hazel, J.E., Jr., Hunter, R.E., Kohl, K., Leap, L.M., Nials, F.L., Topping, D.J., and Yeatts, M., 2008, Application of sedimentary-structure interpretation to geoarchaeological investigations in the Colorado River corridor, Grand Canyon, Arizona: Geomorphology, v. 101, p. 497-509.

Draut, A.E., Sondossi, H.A., Hazel, J.E., Jr., Fairley, H.C., Andrews, T., Brown, C.R., and Vanaman, K.M., 2009, 2008 weather and aeolian sand-transport data from the Colorado River corridor, Grand Canyon, Arizona: U.S. Geological Survey OpenFile Report 2009-1190, 98 p. [http://pubs.usgs.gov/of/2009/1190/].

Fairley, H.C., 2005, Cultural resources in the Colorado River corridor, in Gloss, S.P., Lovich, J.E., and Melis, T.S., eds., The state of the Colorado River ecosystem in Grand Canyon: U.S. Geological Survey Circular 1282, p. 177-192.

Fairley, H.C., and Sondossi, H., 2008, Applying an ecosystem framework to evaluate archaeological site condition along the Colorado River in Grand Canyon National Park, Arizona: In Melis, T.S., Hamill, J.F., Coggins, L.G., Jr., Grams, P.E., Kennedy, T.A., Kubly, D.M., and Ralston, B.E., eds., Proceedings of the Colorado River Basin Science and Resource Management Symposium, November 18-20, 2008, Scottsdale, Arizona. U.S. Geological Survey Scientific Investigations Report 2010-5135, p. 333-341.

Fryrear, D.W., 1986, A field dust sampler: Journal of Soil and Water Conservation, v. 41, p. 117-119.

Goossens, D., Offer, Z., and London, G., 2000, Wind tunnel and field calibration of five aeolian sand traps: Geomorphology, v. 35, p. 233-252.

Goossens, D., 2004, Effect of soil crusting on the emission and transport of wind-eroded sediment—Field measurements on loamy sandy soil: Geomorphology, v. 58, p. 145-160.

Hazel, J.E., Kaplinski, M., Parnell, R.A., Kohl, K., and Schmidt, J.C., 2008a, Monitoring fine-grained sediment in the Colorado River ecosystem, Arizona-Control network and conventional survey techniques: U.S. Geological Survey Open-File Report 2008-1276, 15 p. [http://pubs.usgs.gov/of/2008/1276/]. 
Hazel, J.E., Jr., Kaplinski, M., Parnell, R.A., and Fairley, H.C., 2008b, Aggradation and degradation of the Palisades gully network, 1996 to 2005, with emphasis on the November 2004 high-flow experiment, Grand Canyon National Park, Arizona: U.S. Geological Survey Open-File Report 2008-1264, 14 p. [http://pubs.usgs.gov/of/2008/1264/].

Hazel, J.E.., Jr., Grams, P.E., Schmidt, J.C., and Kaplinski, M., 2010, Sandbar response in Marble and Grand Canyons, Arizona, following the 2008 high-flow experiment on the Colorado River: U.S. Geological Survey Scientific Investigations Report 2010-5015, 52 p. [http://pubs.usgs.gov/sir/2010/5015/].

Hereford, R., Fairley, H.C., Thompson, K.S., and Balsom, J.R., 1993, Surficial geology, geomorphology, and erosion of archeologic sites along the Colorado River, eastern Grand Canyon, Grand Canyon National Park, Arizona: U.S. Geological Survey Open-File Report 93-517, 46 p.

Hereford, R., Thompson, K.S., Burke, K.J., and Fairley, H.C., 1996, Tributary debris fans and the late Holocene alluvial chronology of the Colorado River, eastern Grand Canyon, Arizona: Geological Society of America Bulletin, v. 108, p. 3-19.

Huntoon, P., 2003, Post-Precambrian tectonism in the Grand Canyon region, in Beus, S.S. and Morales, M., eds., Grand Canyon geology (second edition): New York, Oxford University Press, p. 222-259.

Kawamura, R., 1951, Study of sand movement by wind: University of Tokyo, Institute of Science and Technology Report, v. 5 no. 3-4, p. 95-112 [in Japanese].

Lettau, K., and Lettau, H.H., 1977, Experimental and micro-meteorological field studies of dune migration, in Lettau, H.H., and Lettau, K., eds., Exploring the world's driest climates: Madison, University of Wisconsin, Institute of Environmental Science Report 101, p. 110-147.

Leys, J.F., and Eldridge, D.J., 1998, Influence of cryptogamic crust disturbance to wind erosion on sand and loam rangeland soils: Earth Surface Processes and Landforms, v. 23, p. 963-974.

Magirl, C.S., Breedlove, M.J., Webb, R.H., and Griffiths, P.G., 2008, Modeling watersurface elevations and virtual shorelines for the Colorado River in Grand Canyon, Arizona: U.S. Geological Survey Scientific Investigations Report 2008-5075, 40 p. [http://pubs.usgs.gov/sir/2008/5075/]

Mitchell, D.L., Ivanova, D., Rabin, R., Brown, T.J., and Redmond, K., 2002, Gulf of California sea surface temperatures and the North American monsoon-Mechanistic implications from observations: Journal of Climate, v. 15, p. 2261-2281.

Neal, L.A., Gilpin, D., Jonas, L., and Ballagh, J.H., 2000, Cultural resources data synthesis within the Colorado River corridor, Grand Canyon National Park and Glen Canyon National Recreation Area, Arizona: SWCA, Inc., Cultural Resources Report 98-85.

Nickling, W.G., and McKenna Neuman, C., 1997, Wind tunnel evaluation of a wedgeshaped aeolian sediment trap: Geomorphology, v. 18, p. 333-345.

O'Brien, G., and Pederson, J., 2008, Gully erosion processes and parameters and six cultural sites along the Colorado River in Grand Canyon National Park, Arizona: Draft report, cooperative agreement 04HQAG0122 and subagreement 04122HS010, Utah State University and U.S. Geological Survey, Grand Canyon Monitoring and Research Center, 126 p. Internal report available on request from the Grand Canyon Monitoring and Research Center, Flagstaff, Arizona. 
Saunders, S., Montgomery, C., Easley, T., and Spencer, T., 2008, Hotter and drier-The west's changing climate: New York, Rocky Mountain Climate Organization and Natural Resources Defense Council, $54 \mathrm{p}$.

Schmidt, J.C., and Graf, J.B., 1987, Aggradation and degradation of alluvial sand deposits, 1965 to 1986, Colorado River, Grand Canyon National Park, Arizona: U.S. Geological Survey Open-File Report 87-555, 120 p.

Stout, J.E., and Fryrear, D.W., 1989, Performance of a windblown-particle sampler: American Society of Agricultural Engineers Transactions, v. 32, p. 2041-2045.

Thompson, K.S., and Potochnik, A.R., 2000, Development of a geomorphic model to predict erosion of pre-dam Colorado River terraces containing archaeological resources: SWCA, Inc. Cultural Resources Report 99-257.

Topping, D.J., Rubin, D.M., Schmidt, J.C., Hazel, J.E. Jr., Wright, S.A., Kaplinski, M., Draut, A.E., and Breedlove, M.J., 2006, Comparison of sediment-transport and barresponse results from the 1996 and 2004 controlled-flood experiments on the Colorado River in Grand Canyon: Proceedings of the $8^{\text {th }}$ Federal Interagency Sediment Conference, Reno, Nevada, April 2006, ISBN 0-9779007-1-1.

Webb, R.H., Schmidt, J.C., Marzolf, G.R., and Valdez, R.A., eds., 1999, The controlled flood in Grand Canyon: Washington, D.C., American Geophysical Union Geophysical Monograph 110, $367 \mathrm{p}$.

Yeatts, M., 1996, High elevation sand deposition and retention from the 1996 spike flow-An assessment for cultural resources stabilization, in Balsom, J.R., and Larralde, S., eds., Mitigation and monitoring of cultural resources in response to the experimental habitat building flow in Glen and Grand Canyons, Spring 1996: Flagstaff, Ariz., Report to Bureau of Reclamation, and Grand Canyon Monitoring and Research Center, p. 124-158. Internal report available on request from the Grand Canyon Monitoring and Research Center, Flagstaff, Arizona.

Zobeck, T.M., Sterk, G., Funk, R., Rajot, J.L., Stout, J.E., and Van Pelt, R.S., 2003, Measurement and data analysis methods for field-scale wind erosion studies and model validation: Earth Surface Processes and Landforms, v. 28, p. 1163-1188. 


\section{Tables}

Table 1. Approximate river miles, station names, abbreviations, and equipment deployed at each study site, month in which the station was established, and setting of aeolian dunes at each site (Modern Fluvial Sourced [MFS], Relict Fluvial Sourced [RFS], or intermediate, receiving some sand from modern fluvial deposits and some from relict deposits).

\begin{tabular}{llrcc}
\hline Approximate river mile & Station name & Equipment & Date established & Dune field type \\
\hline 25 & AZ C:05:0031 L & weather station, sand traps & $2 / 23 / 2007$ & MFS \\
25 & AZ C:05:0031 U & weather station, sand traps & $2 / 23 / 2007$ & MFS \\
60 & AZ C:13:0365 L & weather station, sand traps & $2 / 9 / 2008$ & MFS \\
60 & AZ C:13:0365 U & weather station, sand traps & $2 / 9 / 2008$ & MFS \\
60 & AZ C:13:0006 & weather station, sand traps & $2 / 25 / 2007$ & MFS? \\
65 & AZ C:13:0336 U & weather station, sand traps & $2 / 26 / 2007$ & RFS \\
65 & AZ C:13:0336 L & sand traps & $2 / 9 / 2008$ & on cobble bar \\
70 & AZ C:13:0321 & sand traps & $2 / 10 / 2008$ & MFS \\
70 & AZ C:13:0346 L & weather station, sand traps & $2 / 27 / 2007$ & RFS \\
70 & AZ C:13:0346 U & weather station, sand traps & $2 / 27 / 2007$ & RFS \\
135 & AZ B:11:0281 & weather station, sand traps & $3 / 4 / 2007$ & intermediate \\
203 & AZ A:15:0033 & weather station, sand traps & $3 / 7 / 2007$ & RFS \\
223 & AZ G:03:0072 L & sand traps & $3 / 8 / 2007$ & MFS \\
223 & AZ G:03:0072 U & weather station, sand traps & $3 / 8 / 2007$ & MFS \\
\hline
\end{tabular}


Table 2. Total rainfall, in mm, recorded daily at each of the weather stations. N/A indicates that the station did not collect data that day.

\begin{tabular}{|c|c|c|c|c|c|c|c|c|c|c|c|c|}
\hline Date & AZ C:05:0031 L & AZ C:05:0031 U & AZ C:13:0365 L & AZ C:13:0365 U & AZ C:13:0006 & AZ C:13:0336 U & AZ C:13:0346 L & AZ C:13:0346 U & AZ B:11:0281 & AZ A:15:0033 & AZ G:03:0072 U & Year Day \\
\hline $1 / 1 / 09$ & 0 & 0 & 0 & 0 & 0 & 0 & 0 & 0 & 0 & 0 & 0 & 1 \\
\hline $1 / 2 / 09$ & 0 & 0 & 0 & 0 & 0 & 0 & 0 & 0 & 0 & 0 & 0 & 2 \\
\hline $1 / 3 / 09$ & 0 & 0 & 0.71 & 0.66 & 0.38 & 0.36 & 0.81 & 0.66 & 1.65 & 0.10 & 0.08 & 3 \\
\hline $1 / 4 / 09$ & 0 & 0 & 0 & 0 & 0 & 0 & 0 & 0 & 0 & 0 & 0 & 4 \\
\hline $1 / 5 / 09$ & 0 & 0 & 0 & 0 & 0 & 0 & 0 & 0 & 0.28 & 0 & 0 & 5 \\
\hline $1 / 6 / 09$ & 0 & 0 & 0 & 0 & 0 & 0 & 0 & 0 & 0 & 0 & 0 & 6 \\
\hline $1 / 7 / 09$ & 0 & 0 & 0 & 0 & 0 & 0 & 0 & 0 & 0 & 0 & 0 & 7 \\
\hline $1 / 8 / 09$ & 0 & 0 & 0 & 0 & 0 & 0 & 0 & 0 & 0 & 0 & 0 & 8 \\
\hline 1/9/09 & 0 & 0 & 0 & 0 & 0 & 0 & 0 & 0 & 0 & 0 & 0 & 9 \\
\hline $1 / 10 / 09$ & 0 & 0 & 0 & 0 & 0 & 0 & 0 & 0 & 0 & 0 & 0 & 10 \\
\hline $1 / 11 / 09$ & 0 & 0 & 0 & 0 & 0 & 0.03 & 0 & 0 & 0.03 & 0 & 0 & 11 \\
\hline $1 / 12 / 09$ & 0 & 0 & 0 & 0 & 0 & 0 & 0 & 0 & 0 & 0 & 0 & 12 \\
\hline $1 / 13 / 09$ & 0 & 0 & 0 & 0 & 0 & 0 & 0 & 0 & 0 & 0 & 0 & 13 \\
\hline $1 / 14 / 09$ & 0 & 0 & 0 & 0 & 0 & 0 & 0 & 0 & 0 & 0 & 0 & 14 \\
\hline $1 / 15 / 09$ & 0 & 0 & 0 & 0 & 0 & 0 & 0 & 0 & 0 & 0 & 0 & 15 \\
\hline $1 / 16 / 09$ & 0 & 0 & 0 & 0 & 0 & 0 & 0 & 0 & 0 & 0 & 0 & 16 \\
\hline $1 / 17 / 09$ & 0 & 0 & 0 & 0 & 0 & 0 & 0 & 0 & 0 & 0 & 0 & 17 \\
\hline $1 / 18 / 09$ & 0 & 0 & 0 & 0 & 0 & 0 & 0 & 0 & 0 & 0 & 0 & 18 \\
\hline $1 / 19 / 09$ & 0 & 0 & 0 & 0 & 0 & 0 & 0 & 0 & 0 & 0 & 0 & 19 \\
\hline $1 / 20 / 09$ & 0 & 0 & 0 & 0 & 0 & 0 & 0 & 0 & 0 & 0 & 0 & 20 \\
\hline $1 / 21 / 09$ & 0 & 0 & 0 & 0 & 0 & 0 & 0 & 0 & 0 & 0 & 0 & 21 \\
\hline $1 / 22 / 09$ & 0.08 & 0.08 & 4.60 & 4.45 & 5.13 & 6.53 & 3.07 & 2.92 & 0.74 & 0.03 & 0.03 & 22 \\
\hline $1 / 23 / 09$ & 1.40 & 1.55 & 0.18 & 0.23 & 0.18 & 0.99 & 1.85 & 1.70 & 8.36 & 2.03 & 6.02 & 23 \\
\hline $1 / 24 / 09$ & 0.48 & 0.56 & 1.52 & 1.68 & 1.32 & 0.46 & 0.25 & 0.15 & 0.25 & 0.69 & 0.15 & 24 \\
\hline $1 / 25 / 09$ & 0.10 & 0.15 & 0.63 & 0.63 & 1.30 & 0.05 & 0.10 & 0.05 & 1.24 & 0.15 & 0 & 25 \\
\hline $1 / 26 / 09$ & 0 & 0 & 0.03 & 0 & 0.03 & 0 & 0.03 & 0.03 & 3.15 & 0.41 & 0 & 26 \\
\hline $1 / 27 / 09$ & 0 & 0 & 0 & 0 & 0 & 0 & 0 & 0 & 0 & 0 & 0 & 27 \\
\hline $1 / 28 / 09$ & 0 & 0 & 0 & 0 & 0 & 0 & 0 & 0 & 0 & 0 & 0 & 28 \\
\hline $1 / 29 / 09$ & 0 & 0 & 0 & 0 & 0 & 0 & 0 & 0 & 0 & 0 & 0 & 29 \\
\hline $1 / 30 / 09$ & 0 & 0 & 0 & 0 & 0 & 0 & 0 & 0 & 0 & 0 & 0 & 30 \\
\hline $1 / 31 / 09$ & 0 & 0 & 0 & 0 & 0 & 0 & 0 & 0 & 0 & 0 & 0 & 31 \\
\hline $2 / 1 / 09$ & 0 & 0 & 0 & 0 & 0 & 0 & 0 & 0 & 0 & 0 & 0 & 32 \\
\hline $2 / 2 / 09$ & 0 & 0 & 0 & 0 & 0 & 0 & 0 & 0 & 0 & 0 & 0 & 33 \\
\hline $2 / 3 / 09$ & 0 & 0 & 0 & 0 & 0 & 0 & 0 & 0 & 0 & 0 & 0 & 34 \\
\hline $2 / 4 / 09$ & 0 & 0 & 0 & 0 & 0 & 0 & 0 & 0 & 0 & 0 & 0 & 35 \\
\hline $2 / 5 / 09$ & 0 & 0 & 0 & 0 & 0 & 0 & 0 & 0 & 0 & 0 & 0 & 36 \\
\hline 2/6/09 & 0 & 0 & 0 & 0 & 0 & 0 & 0 & 0 & 0 & 0 & 0 & 37 \\
\hline $2 / 7 / 09$ & 0 & 0 & 0 & 0 & 0 & 0 & 0 & 0 & 0 & 9.86 & 7.49 & 38 \\
\hline $2 / 8 / 09$ & 2.79 & 3.12 & 3.23 & 3.07 & 2.44 & 2.06 & 1.60 & 1.80 & 5.56 & 2.03 & 1.37 & 39 \\
\hline $2 / 9 / 09$ & 1.75 & 1.22 & 9.02 & 8.76 & 9.86 & 8.69 & 8.94 & 8.84 & 7.39 & 6.07 & 24.77 & 40 \\
\hline $2 / 10 / 09$ & 0.03 & 0 & 0.46 & 0.38 & 0.74 & 1.17 & 0.69 & 0.58 & 0.08 & 0 & 0.61 & 41 \\
\hline $2 / 11 / 09$ & 0 & 0 & 0 & 0 & 0 & 0 & 0 & 0 & 0 & 0 & 0 & 42 \\
\hline
\end{tabular}


Table 2. (continued)

\begin{tabular}{|c|c|c|c|c|c|c|c|c|c|c|c|c|}
\hline Date & AZ C:05:0031 L & AZ C:05:0031 U & AZ C:13:0365 L & AZ C:13:0365 U & AZ C:13:0006 & AZ C:13:0336 U & AZ C:13:0346 L & AZ C:13:0346 U & AZ B:11:0281 & AZ A:15:0033 & AZ G:03:0072 U & Year Day \\
\hline 2/12/09 & 0.38 & 0.38 & 0.23 & 0.25 & 0.05 & 0.08 & 0.05 & 0.03 & 0.25 & 0.13 & 0 & 43 \\
\hline 2/13/09 & 0 & 0 & 0 & 0 & 0 & 0 & 0 & 0 & 0 & 0.71 & 0.03 & 44 \\
\hline $2 / 14 / 09$ & 0 & 0 & 1.45 & 1.65 & 0.48 & 0.03 & 0.30 & 0.20 & 0.56 & 2.18 & 0.43 & 45 \\
\hline 2/15/09 & 0 & 0 & 0 & 0 & 0 & 0 & 0 & 0 & 0 & 0 & 0 & 46 \\
\hline 2/16/09 & 0.03 & 0 & 0.03 & 0.03 & 0 & 0 & 0.03 & 0.03 & 2.06 & 7.85 & 4.65 & 47 \\
\hline 2/17/09 & 0.13 & 0.10 & 1.17 & 1.04 & 0.46 & 0.48 & 0.41 & 0.41 & 0.46 & 0.13 & 0.03 & 48 \\
\hline 2/18/09 & 0 & 0 & 0 & 0 & 0 & 0 & 0 & 0 & 0.46 & 0 & 0 & 49 \\
\hline 2/19/09 & 0 & 0 & 0 & 0 & 0 & 0 & 0 & 0 & 0 & 0 & 0 & 50 \\
\hline 2/20/09 & 0 & 0 & 0 & 0 & 0 & 0 & 0 & 0 & 0 & 0 & 0 & 51 \\
\hline 2/21/09 & 0 & 0 & 0 & 0 & 0 & 0 & 0 & 0 & 0 & 0 & 0 & 52 \\
\hline 2/22/09 & 0 & 0 & 0 & 0 & 0 & 0 & 0.03 & 0 & 0.03 & 0 & 0 & 53 \\
\hline $2 / 23 / 09$ & 0.03 & 0.08 & 0.66 & 0.56 & 0.86 & 1.83 & 1.32 & 1.40 & 0.13 & 0.05 & 0 & 54 \\
\hline 2/24/09 & 0 & 0 & 0 & 0 & 0 & 0 & 0 & 0 & 0 & 0 & 0 & 55 \\
\hline $2 / 25 / 09$ & 0 & 0 & 0 & 0.03 & 0 & 0 & 0 & 0 & 0 & 0 & 0 & 56 \\
\hline 2/26/09 & 0 & 0 & 0 & 0 & 0 & 0 & 0 & 0 & 0 & 0 & 0 & 57 \\
\hline $2 / 27 / 09$ & 0 & 0 & 0 & 0 & 0 & 0 & 0 & 0 & 0 & 0 & 0 & 58 \\
\hline$\underline{2 / 28 / 09}$ & 0 & 0 & 0 & 0 & 0 & 0 & 0 & 0 & 0.03 & 0 & 0 & 59 \\
\hline $3 / 1 / 09$ & 0 & 0 & 0 & 0 & 0 & 0 & 0 & 0 & 0 & 0 & 0 & 60 \\
\hline $3 / 2 / 09$ & 0 & 0 & 0 & 0 & 0 & 0 & 0 & 0 & 0 & 0 & 0 & 61 \\
\hline 3/3/09 & 0 & 0 & 0 & 0.03 & 0 & 0 & 0 & 0 & 0 & 0 & 0 & 62 \\
\hline 3/4/09 & 0 & 0 & 0 & 0.03 & 0 & 0 & 0.03 & 0 & 0 & 0 & 0 & 63 \\
\hline 3/5/09 & 0 & 0 & 0 & 0 & 0 & 0 & 0 & 0 & 0 & 0 & 0 & 64 \\
\hline $3 / 6 / 09$ & 0 & 0 & 0 & 0 & 0 & 0 & 0 & 0 & 0 & 0 & 0 & 65 \\
\hline $3 / 7 / 09$ & 0.08 & 0.05 & 6.96 & 7.82 & 5.16 & 0.99 & 0.97 & 0.84 & 1.04 & 0 & 0.03 & 66 \\
\hline 3/8/09 & 0 & 0 & 0 & 0 & 0 & 0 & 0 & 0 & 0 & 0 & 0 & 67 \\
\hline 3/9/09 & 0 & 0 & 0 & 0.05 & 0 & 0.03 & 0.08 & 0.03 & 0 & 0 & 0 & 68 \\
\hline $3 / 10 / 09$ & 0 & 0 & 0 & 0 & 0 & 0 & 0.08 & 0 & 0 & 0 & 0 & 69 \\
\hline $3 / 11 / 09$ & 0 & 0 & 0 & 0 & 0 & 0 & 0 & 0 & 0 & 0 & 0 & 70 \\
\hline $3 / 12 / 09$ & 0 & 0 & 0.28 & 0.25 & 0.76 & 0.15 & 0.05 & 0.03 & 1.83 & 0.25 & 0.08 & 71 \\
\hline $3 / 13 / 09$ & 0 & 0 & 0 & 0 & 0 & 0 & 0 & 0 & 0 & 0 & 0.03 & 72 \\
\hline $3 / 14 / 09$ & 0 & 0 & 0 & 0 & 0 & 0 & 0 & 0 & 0 & 0 & 0 & 73 \\
\hline $3 / 15 / 09$ & 0 & 0 & 0 & 0 & 0 & 0 & 0 & 0 & 0 & 0 & 0 & 74 \\
\hline 3/16/09 & 0 & 0 & 0 & 0 & 0 & 0 & 0 & 0 & 0 & 0 & 0 & 75 \\
\hline $3 / 17 / 09$ & 0 & 0 & 0 & 0 & 0 & 0 & 0 & 0 & 0 & 0 & 0 & 76 \\
\hline $3 / 18 / 09$ & 0 & 0 & 0 & 0 & 0 & 0 & 0 & 0 & 0 & 0 & 0 & 77 \\
\hline $3 / 19 / 09$ & 0 & 0 & 0 & 0 & 0 & 0 & 0 & 0 & 0 & 0 & 0 & 78 \\
\hline $3 / 20 / 09$ & 0 & 0 & 0 & 0 & 0 & 0 & 0 & 0 & 0 & 0 & 0 & 79 \\
\hline $3 / 21 / 09$ & 0 & 0 & 0 & 0 & 0 & 0 & 0 & 0 & 0 & 0 & 0 & 80 \\
\hline $3 / 22 / 09$ & 5.54 & 6.65 & 0.46 & 0.81 & 0.43 & 0.23 & 0.66 & 0.61 & 7.95 & 5.92 & 2.95 & 81 \\
\hline $3 / 23 / 09$ & 0 & 0 & 0.20 & 0.25 & 0.13 & 0.33 & 0.10 & 0.13 & 0 & 0.25 & 0.10 & 82 \\
\hline $3 / 24 / 09$ & 0 & 0 & 0 & 0 & 0 & 0 & 0 & 0 & 0 & 0.03 & 0 & 83 \\
\hline $3 / 25 / 09$ & 0 & 0 & 0 & 0 & 0 & 0 & 0 & 0 & 0 & 0 & 0 & 84 \\
\hline
\end{tabular}


Table 2. (continued)

\begin{tabular}{|c|c|c|c|c|c|c|c|c|c|c|c|c|}
\hline Date & AZ C:05:0031 L & AZ C:05:0031 U & AZ C:13:0365 L & AZ C:13:0365 U & AZ C:13:0006 & AZ C:13:0336 U & AZ C:13:0346 L & AZ C:13:0346 U & AZ B:11:0281 & AZ A:15:0033 & AZ G:03:0072 U & Year Day \\
\hline 3/26/09 & 0.03 & 0.03 & 0.53 & 0.84 & 0.30 & 0.89 & 0.53 & 0.38 & 0.05 & 0 & 0 & 85 \\
\hline 3/27/09 & 0 & 0 & 0 & 0 & 0 & 0 & 0 & 0 & 0 & 0 & 0 & 86 \\
\hline $3 / 28 / 09$ & 0 & 0 & 0 & 0 & 0 & 0 & 0 & 0 & 0 & 0 & 0 & 87 \\
\hline 3/29/09 & 2.21 & 1.98 & 0.91 & 1.68 & 0.56 & 0.63 & 1.45 & 0.71 & 0.20 & 0 & 0 & 88 \\
\hline 3/30/09 & 0 & 0 & 0.08 & 0.10 & 0.08 & 0.36 & 1.12 & 1.09 & 0 & 0 & 0 & 89 \\
\hline $3 / 31 / 09$ & 0 & 0 & 0 & 0 & 0 & 0 & 0 & 0 & 0 & 0 & 0 & 90 \\
\hline $4 / 1 / 09$ & 0 & 0 & 0 & 0 & 0 & 0 & 0 & 0 & 0 & 0 & 0 & 91 \\
\hline $4 / 2 / 09$ & 0 & 0 & 0 & 0.03 & 0.03 & 0 & 0.03 & 0 & 0 & 0 & 0 & 92 \\
\hline 4/3/09 & 0.56 & 0.43 & 1.75 & 2.24 & 1.32 & 0.71 & 0.71 & 0.86 & 11.96 & 2.06 & 2.21 & 93 \\
\hline $4 / 4 / 09$ & 0 & 0 & 0.03 & 0.03 & 0.03 & 0.03 & 0 & 0 & 0.03 & 0 & 0 & 94 \\
\hline $4 / 5 / 09$ & 0 & 0 & 0 & 0 & 0 & 0 & 0 & 0 & 0 & 0 & 0 & 95 \\
\hline $4 / 6 / 09$ & 0 & 0.03 & 0 & 0 & 0 & 0 & 0 & 0 & 0 & 0 & 0 & 96 \\
\hline $4 / 7 / 09$ & 0 & 0 & 0 & 0 & 0 & 0 & 0 & 0 & 0 & 0 & 0 & 97 \\
\hline $4 / 8 / 09$ & 0 & 0 & 0 & 0.03 & 0 & 0 & 0 & 0 & 0 & 0 & 0 & 98 \\
\hline 4/9/09 & 0 & 0 & 0 & 0 & 0 & 0 & 0 & 0 & 0 & 0 & 0 & 99 \\
\hline $4 / 10 / 09$ & 0 & 0 & 0 & 0 & 0 & 0 & 0 & 0 & 1.78 & 0.08 & 0.15 & 100 \\
\hline 4/11/09 & 0.23 & 0.15 & 0 & 0 & 0 & 2.08 & 3.07 & 3.30 & 4.55 & 6.02 & 8.20 & 101 \\
\hline $4 / 12 / 09$ & 0 & 0 & 0 & 0 & 0 & 0 & 0 & 0 & 0.10 & 0 & 0 & 102 \\
\hline $4 / 13 / 09$ & 0 & 0 & 0 & 0 & 0 & 0 & 0 & 0 & 0 & 0 & 0 & 103 \\
\hline $4 / 14 / 09$ & 0 & 0 & 0 & 0.05 & 0 & 0 & 0.03 & 0 & 0 & 0.03 & 0 & 104 \\
\hline 4/15/09 & 0 & 0 & 0.03 & 0.28 & 0.03 & 0.43 & 0.58 & 0.43 & 0.10 & 0.18 & 0.10 & 105 \\
\hline 4/16/09 & 0.08 & 0.10 & 0 & 0 & 0 & 0 & 0 & 0 & 0 & 1.17 & 0.03 & 106 \\
\hline $4 / 17 / 09$ & 0 & 0 & 0 & 0 & 0 & 0 & 0 & 0 & 0 & 0 & 0 & 107 \\
\hline 4/18/09 & 0 & 0 & 0 & 0 & 0 & 0 & 0 & 0 & 0 & 0 & 0 & 108 \\
\hline 4/19/09 & 0 & 0 & 0 & 0 & 0 & 0 & 0 & 0 & 0 & 0 & 0 & 109 \\
\hline $4 / 20 / 09$ & 0 & 0 & 0 & 0 & 0 & 0 & 0 & 0 & 0 & 0 & 0 & 110 \\
\hline $4 / 21 / 09$ & 0 & 0 & 0 & 0 & 0 & 0 & 0 & 0 & 0 & 0 & 0 & 111 \\
\hline $4 / 22 / 09$ & 0 & 0 & 0 & 0 & 0 & 0 & 0 & 0 & 0 & 0 & 0 & 112 \\
\hline 4/23/09 & 0 & 0 & 0 & 0 & 0 & 0 & 0 & 0 & 0 & 0 & 0 & 113 \\
\hline $4 / 24 / 09$ & 0 & 0 & 0 & 0.13 & 0 & 0 & 0.03 & 0 & 0 & 0 & 0 & 114 \\
\hline $4 / 25 / 09$ & 0 & 0 & 0 & 0.15 & 0 & 0.05 & 0.05 & 0 & 0 & 0 & 0 & 115 \\
\hline $4 / 26 / 09$ & 0 & 0 & 0 & 0 & 0 & 0 & 0 & 0 & 0 & 0 & 0 & 116 \\
\hline $4 / 27 / 09$ & 0 & 0 & 0 & 0 & 0 & 0 & 0 & 0 & 0 & 0 & 0 & 117 \\
\hline $4 / 28 / 09$ & 0 & 0 & 0 & 0 & 0 & 0 & 0 & 0 & 0 & 0 & 0 & 118 \\
\hline $4 / 29 / 09$ & 0 & 0 & 0 & 0 & 0 & 0 & 0 & 0 & 0 & 0 & 0 & 119 \\
\hline $4 / 30 / 09$ & 0.03 & 0 & 0 & 0.03 & 0 & 0 & 0 & 0 & 0 & 0 & 0 & 120 \\
\hline $5 / 1 / 09$ & 0 & 0 & 0 & 0 & 0 & 0 & 0 & 0 & 0 & 0.03 & 0 & 121 \\
\hline $5 / 2 / 09$ & 0.03 & 0 & 0.03 & 0.03 & 0.03 & 0 & 0 & 0 & 0 & 0 & 0 & 122 \\
\hline $5 / 3 / 09$ & 0 & 0 & 0 & 0 & 0 & 0 & 0 & 0 & 0 & 0 & 0 & 123 \\
\hline $5 / 4 / 09$ & 0 & 0 & 0.03 & 0 & 0 & 0 & 0 & 0 & 0 & 0 & 0 & 124 \\
\hline $5 / 5 / 09$ & 0 & 0 & 0 & 0 & 0 & 0 & 0 & 0 & 0 & 0 & 0 & 125 \\
\hline $5 / 6 / 09$ & 0 & 0 & 0 & 0 & 0 & 0 & 0 & 0 & 0 & 0 & 0 & 126 \\
\hline
\end{tabular}


Table 2. (continued)

\begin{tabular}{|c|c|c|c|c|c|c|c|c|c|c|c|c|}
\hline Date & AZ C:05:0031 L & AZ C:05:0031 U & AZ C:13:0365 L & AZ C:13:0365 U & AZ C:13:0006 & AZ C:13:0336 U & AZ C:13:0346 L & AZ C:13:0346 U & AZ B:11:0281 & AZ A:15:0033 & AZ G:03:0072 U & Year Day \\
\hline $5 / 7 / 09$ & 0 & 0 & 0.03 & 0 & 0 & 0 & 0 & 0 & 0 & 0 & 0.03 & 127 \\
\hline $5 / 8 / 09$ & 0 & 0 & 0 & 0 & 0 & 0 & 0 & 0 & 0 & 0 & 0 & 128 \\
\hline $5 / 9 / 09$ & 0.03 & 0 & 0.05 & 0 & 0 & 0 & 0 & 0 & 0 & 0 & 0 & 129 \\
\hline $5 / 10 / 09$ & 0 & 0 & 0 & 0 & 0 & 0 & 0 & 0 & 0 & 0 & 0 & 130 \\
\hline $5 / 11 / 09$ & 0 & 0 & 0 & 0 & 0 & 0 & 0 & 0 & 0 & 0.03 & 0 & 131 \\
\hline $5 / 12 / 09$ & 0 & 0 & 0 & 0 & 0 & 0 & 0 & 0 & 0 & 0 & 0 & 132 \\
\hline $5 / 13 / 09$ & 0 & 0 & 0 & 0 & 0 & 0 & 0 & 0 & 0 & 0 & 0 & 133 \\
\hline $5 / 14 / 09$ & 0.03 & 0 & 0 & 0 & 0 & 0 & 0 & 0 & 0 & 0 & 0 & 134 \\
\hline $5 / 15 / 09$ & 0 & 0 & 0.03 & 0.05 & 0 & 0 & 0 & 0 & 0 & 0 & 0 & 135 \\
\hline 5/16/09 & 0.03 & 0 & 0.05 & 0 & 0 & 0 & 0 & 0 & 0 & 0 & 0 & 136 \\
\hline $5 / 17 / 09$ & 0 & 0 & 0 & 0 & 0 & 0 & N/A & 0 & 0 & 0 & 0 & 137 \\
\hline $5 / 18 / 09$ & 0 & 0 & 0 & 0 & 0 & 0 & N/A & 0 & 0 & 0.03 & 0 & 138 \\
\hline 5/19/09 & 0.10 & 0.13 & 0 & 0 & 0 & 0 & N/A & 0.18 & 0 & 0 & 0 & 139 \\
\hline $5 / 20 / 09$ & 0 & 0.05 & 0 & 0.05 & 0 & 0 & N/A & 0 & 0 & 0 & 0 & 140 \\
\hline $5 / 21 / 09$ & 1.55 & 1.55 & 1.55 & 1.57 & 3.96 & 1.88 & N/A & 2.62 & 0.20 & 0.05 & 0.10 & 141 \\
\hline $5 / 22 / 09$ & 5.72 & 4.95 & 38.10 & 39.40 & 45.31 & 40.06 & N/A & 31.45 & 36.58 & 3.45 & 0.05 & 142 \\
\hline $5 / 23 / 09$ & 13.84 & 12.62 & 20.73 & 23.72 & 3.86 & 4.44 & N/A & 14.71 & 10.52 & 0.36 & 12.67 & 143 \\
\hline $5 / 24 / 09$ & 0.10 & 0.05 & 0 & 0.05 & 0.05 & 0.61 & $\mathrm{~N} / \mathrm{A}$ & 0.79 & 0.18 & 0.03 & 1.02 & 144 \\
\hline $5 / 25 / 09$ & 0 & 0 & 2.62 & 2.11 & 0.36 & 0.05 & N/A & 0.28 & 0 & 0 & 0 & 145 \\
\hline $5 / 26 / 09$ & 1.91 & 1.55 & 1.45 & 1.68 & 2.59 & 1.50 & N/A & 0 & 0.30 & 0 & 0 & 146 \\
\hline $5 / 27 / 09$ & 0 & 0 & 0.03 & 0 & 0 & 0 & N/A & 0 & 0 & 0 & 0 & 147 \\
\hline $5 / 28 / 09$ & 0 & 0.03 & 0.30 & 0.38 & 0.53 & 1.19 & N/A & 4.47 & 0.05 & 0 & 0.03 & 148 \\
\hline $5 / 29 / 09$ & 0.05 & 0.08 & 0 & 0 & 0.10 & 0.03 & $\mathrm{~N} / \mathrm{A}$ & 0.05 & 0 & 1.14 & 0.58 & 149 \\
\hline $5 / 30 / 09$ & 1.40 & 1.52 & 0 & 0 & 0.03 & 0.13 & N/A & 0 & 0.66 & 0.38 & 1.88 & 150 \\
\hline $5 / 31 / 09$ & 0 & 0 & 0 & 0.03 & 0 & 0 & $\mathrm{~N} / \mathrm{A}$ & 0 & 0.03 & 0 & 0 & 151 \\
\hline $6 / 1 / 09$ & 0.23 & 0.15 & 0 & 0 & 0 & 0 & N/A & 0 & 0.84 & 0.03 & 0 & 152 \\
\hline $6 / 2 / 09$ & 0 & 0 & 0 & 0.08 & 0 & 0 & N/A & 0.05 & 0 & 0 & 0 & 153 \\
\hline $6 / 3 / 09$ & 0.05 & 0 & 0 & 0 & 0 & 0 & N/A & 0 & 0 & 0 & 0 & 154 \\
\hline $6 / 4 / 09$ & 0 & 0 & 0 & 0 & 0 & 0 & N/A & 0 & 0 & 0 & 0 & 155 \\
\hline $6 / 5 / 09$ & 0.03 & 0.03 & 0 & 0 & 0 & 0 & N/A & 0 & 0 & 0 & 0 & 156 \\
\hline $6 / 6 / 09$ & 0 & 0 & 0 & 0 & 0 & 0 & N/A & 0 & 0 & 0.03 & 0 & 157 \\
\hline $6 / 7 / 09$ & 0 & 0 & 0 & 0 & 0 & 0 & N/A & 0 & 0 & 0 & 0 & 158 \\
\hline 6/8/09 & 0 & 0 & 0 & 0 & 0 & 0 & N/A & 0 & 0 & 0 & 0 & 159 \\
\hline 6/9/09 & 0 & 0.03 & 0 & 0 & 0.05 & 0 & $\mathrm{~N} / \mathrm{A}$ & 0 & 0.13 & 0.15 & 0.61 & 160 \\
\hline $6 / 10 / 09$ & 0 & 0.03 & 0 & 0 & 0 & 0 & $\mathrm{~N} / \mathrm{A}$ & 0 & 0.08 & 0 & 0 & 161 \\
\hline 6/11/09 & 0 & 0 & 0 & 0 & 0 & 0 & N/A & 0 & 0 & 0 & 0 & 162 \\
\hline 6/12/09 & 0 & 0 & 0 & 0 & 0 & 0 & N/A & 0 & 0 & 0 & 0 & 163 \\
\hline $6 / 13 / 09$ & 0 & 0 & 0 & 0 & 0 & 0 & N/A & 0 & 0.03 & 0 & 0 & 164 \\
\hline $6 / 14 / 09$ & 0.03 & 0 & 0 & 0 & 0 & 0 & N/A & 0 & 0 & 0 & 0 & 165 \\
\hline 6/15/09 & 0 & 0 & 0 & 0 & 0 & 0 & N/A & 0 & 0 & 0 & 0 & 166 \\
\hline 6/16/09 & 0 & 0 & 0 & 0.03 & 0 & 0 & N/A & 0 & 0 & 0.41 & 0.25 & 167 \\
\hline $6 / 17 / 09$ & 0.25 & 0.15 & 1.04 & 1.17 & 1.52 & 2.11 & N/A & 1.78 & 1.45 & 1.14 & 3.63 & 168 \\
\hline
\end{tabular}


Table 2. (continued)

\begin{tabular}{|c|c|c|c|c|c|c|c|c|c|c|c|c|}
\hline Date & AZ C:05:0031 L & AZ C:05:0031 U & AZ C:13:0365 L & AZ C:13:0365 U & AZ C:13:0006 & AZ C:13:0336 U & AZ C:13:0346 L & AZ C:13:0346 U & AZ B:11:0281 & AZ A:15:0033 & AZ G:03:0072 U & Year Day \\
\hline 6/18/09 & 0.94 & 0.76 & 0 & 0 & 0.97 & 0 & $N / A$ & 0 & 0 & 0.03 & 0 & 169 \\
\hline 6/19/09 & 0.03 & 0 & 0 & 0 & 0 & 0 & $N / A$ & 0 & 0 & 0 & 0 & 170 \\
\hline 6/20/09 & 0.05 & 0.05 & 0.05 & 0.08 & 0.23 & 0.03 & $N / A$ & 0 & 0.10 & 0 & 0 & 171 \\
\hline $6 / 21 / 09$ & 0 & 0 & 0 & 0 & 0 & 0 & $\mathrm{~N} / \mathrm{A}$ & 0 & 0 & 0 & 0 & 172 \\
\hline $6 / 22 / 09$ & 0 & 0 & 0 & 0 & 0 & 0 & N/A & 0 & 0 & 0 & 0 & 173 \\
\hline 6/23/09 & 0.03 & 0 & 0 & 0 & 0 & 0 & $\mathrm{~N} / \mathrm{A}$ & 0 & 0 & 0 & 0 & 174 \\
\hline $6 / 24 / 09$ & 0.03 & 0 & 0.13 & 0.13 & 0.08 & 0 & $\mathrm{~N} / \mathrm{A}$ & 0 & 0 & 0.03 & 0.20 & 175 \\
\hline $6 / 25 / 09$ & 4.80 & 4.22 & 2.18 & 1.83 & 2.64 & 1.75 & $\mathrm{~N} / \mathrm{A}$ & 2.26 & 0.03 & 0.03 & 0.03 & 176 \\
\hline $6 / 26 / 09$ & 5.05 & 4.98 & 3.94 & 3.84 & 1.93 & 3.99 & $\mathrm{~N} / \mathrm{A}$ & 10.80 & 2.95 & 0.25 & 1.02 & 177 \\
\hline $6 / 27 / 09$ & 0 & 0 & 0 & 0 & 0 & 0 & $N / A$ & 0 & 0 & 0 & 0 & 178 \\
\hline 6/28/09 & 0 & 0 & 0 & 0.03 & 0 & 0 & $N / A$ & 0 & 0 & 0 & 0 & 179 \\
\hline 6/29/09 & 0 & 0 & 0 & 0 & 0 & 0 & N/A & 0 & 0 & 0 & 0 & 180 \\
\hline $6 / 30 / 09$ & 0 & 0 & 0 & 0 & 0 & 0 & $\mathrm{~N} / \mathrm{A}$ & 0 & 0 & 0.18 & 0 & 181 \\
\hline $7 / 1 / 09$ & 0.03 & 0.03 & 0 & 0 & 0 & 0 & N/A & 0 & 0 & 15.37 & 10.31 & 182 \\
\hline $7 / 2 / 09$ & 0.05 & 0 & 0 & 0 & 0 & 0.03 & $\mathrm{~N} / \mathrm{A}$ & 0 & 0 & 0.08 & 0.13 & 183 \\
\hline 7/3/09 & 2.44 & 2.18 & 47.04 & 46.96 & 11.63 & 17.53 & $\mathrm{~N} / \mathrm{A}$ & 5.84 & 0 & 0.03 & 0.25 & 184 \\
\hline $7 / 4 / 09$ & 0 & 0 & 0 & 0 & 0 & 0 & $\mathrm{~N} / \mathrm{A}$ & 0 & 0 & 0 & 0 & 185 \\
\hline $7 / 5 / 09$ & 0 & 0 & 0 & 0 & 0 & 0 & $\mathrm{~N} / \mathrm{A}$ & 0 & 0 & 0 & 0 & 186 \\
\hline $7 / 6 / 09$ & 0 & 0 & 0 & 0 & 0 & 0 & $\mathrm{~N} / \mathrm{A}$ & 0 & 0 & 0 & 0 & 187 \\
\hline $7 / 7 / 09$ & 0 & 0 & 0 & 0 & 0 & 0 & $\mathrm{~N} / \mathrm{A}$ & 0 & 0 & 0 & 0 & 188 \\
\hline $7 / 8 / 09$ & 0 & 0 & 0 & 0 & 0 & 0 & $\mathrm{~N} / \mathrm{A}$ & 0 & 0 & 0 & 0 & 189 \\
\hline $7 / 9 / 09$ & 0 & 0 & 0 & 0.03 & 0 & 0 & $\mathrm{~N} / \mathrm{A}$ & 0 & 0 & 0 & 0 & 190 \\
\hline $7 / 10 / 09$ & 0 & 0 & 0 & 0 & 0 & 0 & $\mathrm{~N} / \mathrm{A}$ & 0 & 0 & 0 & 0 & 191 \\
\hline $7 / 11 / 09$ & 0 & 0 & 0.03 & 0.03 & 0.81 & 0.43 & $\mathrm{~N} / \mathrm{A}$ & 0.15 & 11.79 & 0.03 & 0.03 & 192 \\
\hline $7 / 12 / 09$ & 0.46 & 0.30 & 0 & 0 & 0 & 0 & $\mathrm{~N} / \mathrm{A}$ & 1.17 & 0.41 & 0 & 0 & 193 \\
\hline $7 / 13 / 09$ & 0 & 0 & 0 & 0 & 0 & 0 & $\mathrm{~N} / \mathrm{A}$ & 0 & 0 & 0 & 0 & 194 \\
\hline $7 / 14 / 09$ & 0 & 0 & 0 & 0 & 0 & 0 & $\mathrm{~N} / \mathrm{A}$ & 0 & 0 & 0 & 0 & 195 \\
\hline $7 / 15 / 09$ & 2.08 & 2.39 & 0 & 0 & 0 & 0 & $\mathrm{~N} / \mathrm{A}$ & 0 & 0 & 0 & 0.03 & 196 \\
\hline $7 / 16 / 09$ & 0 & 0 & 0 & 0 & 0 & 0 & $\mathrm{~N} / \mathrm{A}$ & 0 & 0 & 0 & 0 & 197 \\
\hline $7 / 17 / 09$ & 0 & 0 & 0 & 0 & 0 & 0 & $\mathrm{~N} / \mathrm{A}$ & 0 & 0 & 0 & 0 & 198 \\
\hline $7 / 18 / 09$ & 0 & 0 & 0 & 0 & 0 & 0 & $\mathrm{~N} / \mathrm{A}$ & 0 & 0 & 0.03 & 3.66 & 199 \\
\hline $7 / 19 / 09$ & 0.86 & 0.84 & 4.29 & 4.47 & 3.02 & 0 & $\mathrm{~N} / \mathrm{A}$ & 0 & 0 & 0.30 & 0.05 & 200 \\
\hline $7 / 20 / 09$ & 11.40 & 10.26 & 0.53 & 0.43 & 4.80 & 27.08 & $\mathrm{~N} / \mathrm{A}$ & 0.03 & 0 & 0.64 & 0.97 & 201 \\
\hline $7 / 21 / 09$ & 0.05 & 0.10 & 0 & 0 & 0 & 0 & $\mathrm{~N} / \mathrm{A}$ & 0 & 0 & 0 & 1.83 & 202 \\
\hline $7 / 22 / 09$ & 0 & 0 & 0 & 0 & 0.03 & 0 & $\mathrm{~N} / \mathrm{A}$ & 0 & 0 & 0 & 0.38 & 203 \\
\hline $7 / 23 / 09$ & 0 & 0 & 0 & 0 & 0 & 0 & $\mathrm{~N} / \mathrm{A}$ & 0 & 0 & 17.27 & 0.74 & 204 \\
\hline $7 / 24 / 09$ & 0.25 & 0.15 & 0.61 & 0.86 & 0.86 & 2.44 & $\mathrm{~N} / \mathrm{A}$ & 3.10 & 0.08 & 0.41 & 0.43 & 205 \\
\hline $7 / 25 / 09$ & 4.37 & 3.89 & 0 & 0 & 0 & 0 & $\mathrm{~N} / \mathrm{A}$ & 0 & 0 & 0 & 0 & 206 \\
\hline $7 / 26 / 09$ & 0 & 0 & 0 & 0 & 0 & 0 & $\mathrm{~N} / \mathrm{A}$ & 0 & 0 & 0 & 0 & 207 \\
\hline $7 / 27 / 09$ & 0.13 & 0.05 & 0.08 & 0.10 & 0.43 & 0 & $\mathrm{~N} / \mathrm{A}$ & 0 & 0 & 0 & 0 & 208 \\
\hline $7 / 28 / 09$ & 0.61 & 0.56 & 16.13 & 18.64 & 3.43 & 0.03 & $\mathrm{~N} / \mathrm{A}$ & 0.08 & 0.99 & 0 & 0 & 209 \\
\hline $7 / 29 / 09$ & 0 & 0 & 0 & 0 & 0 & 0 & $\mathrm{~N} / \mathrm{A}$ & 0 & 0 & 0 & 0 & 210 \\
\hline
\end{tabular}


Table 2. (continued)

\begin{tabular}{|c|c|c|c|c|c|c|c|c|c|c|c|c|}
\hline Date & AZ C:05:0031 L & AZ C:05:0031 U & AZ C:13:0365 L & AZ C:13:0365 U & AZ C:13:0006 & AZ C:13:0336 U & AZ C:13:0346 L & AZ C:13:0346 U & AZ B:11:0281 & AZ A:15:0033 & AZ G:03:0072 U & Year Day \\
\hline 7/30/09 & 0.05 & 0 & 0 & 0.05 & 0.10 & 0 & N/A & 0 & 0 & 0 & 0 & 211 \\
\hline 7/31/09 & 0 & 0 & 0 & 0.05 & 0.03 & 0 & N/A & 0 & 0 & 0 & 0 & 212 \\
\hline $8 / 1 / 09$ & 0 & 0 & 0 & 0 & 0 & 0 & $\mathrm{~N} / \mathrm{A}$ & 0 & 0 & 0 & 0.03 & 213 \\
\hline 8/2/09 & 0 & 0 & 0 & 0 & 0 & 0 & N/A & 0 & 0 & 0 & 0 & 214 \\
\hline 8/3/09 & 0 & 0 & 0 & 0 & 0 & 0 & N/A & 0 & 0 & 0 & 0 & 215 \\
\hline $8 / 4 / 09$ & 0 & 0 & 0 & 0 & 0 & 0 & $\mathrm{~N} / \mathrm{A}$ & 0 & 0 & 0 & 0 & 216 \\
\hline 8/5/09 & 0.08 & 0.05 & 0.23 & 0.30 & 0.38 & 0.25 & $\mathrm{~N} / \mathrm{A}$ & 0.25 & 0.08 & 0 & 0 & 217 \\
\hline 8/6/09 & 0 & 0 & 0 & 0.03 & 0.03 & 0 & $\mathrm{~N} / \mathrm{A}$ & 0 & 0 & 0 & 0 & 218 \\
\hline 8/7/09 & 0 & 0 & 0 & 0 & 0 & 0 & $\mathrm{~N} / \mathrm{A}$ & 0 & 0 & 0 & 0 & 219 \\
\hline 8/8/09 & 0 & 0 & 0 & 0 & 0 & 0 & $\mathrm{~N} / \mathrm{A}$ & 0 & 0 & 0 & 0 & 220 \\
\hline $8 / 9 / 09$ & 0 & 0 & 0 & 0 & 0 & 0 & $\mathrm{~N} / \mathrm{A}$ & 0 & 0 & 0 & 0 & 221 \\
\hline 8/10/09 & 0 & 0 & 0 & 0 & 0 & 0 & N/A & 0 & 0 & 0 & 0 & 222 \\
\hline 8/11/09 & 0 & 0 & 0 & 0 & 0 & 0 & $\mathrm{~N} / \mathrm{A}$ & 0 & 0 & 0 & 0 & 223 \\
\hline 8/12/09 & 0 & 0 & 0 & 0 & 0 & 0 & N/A & 0 & 0.18 & 0.13 & 0 & 224 \\
\hline $8 / 13 / 09$ & 1.24 & 0.99 & 0.20 & 0.20 & 0 & 0 & $\mathrm{~N} / \mathrm{A}$ & 0 & 1.75 & 35.41 & 5.31 & 225 \\
\hline $8 / 14 / 09$ & 0 & 0 & 0.13 & 0.18 & 0.03 & 0.46 & N/A & 5.03 & 0 & 0 & 0 & 226 \\
\hline 8/15/09 & 0 & 0 & 0 & 0 & 0 & 0 & $\mathrm{~N} / \mathrm{A}$ & 0 & 0 & 0 & 0 & 227 \\
\hline $8 / 16 / 09$ & 0 & 0 & 0 & 0 & 0 & 0 & N/A & 0 & 0 & 0 & 0 & 228 \\
\hline $8 / 17 / 09$ & 0 & 0 & 0 & 0 & 0 & 0 & $\mathrm{~N} / \mathrm{A}$ & 0 & 0 & 0 & 0 & 229 \\
\hline 8/18/09 & 0 & 0 & 0 & 0 & 0 & 0 & N/A & 0 & 0 & 0 & 0 & 230 \\
\hline 8/19/09 & 0 & 0 & 0 & 0 & 0 & 0 & $\mathrm{~N} / \mathrm{A}$ & 0 & 0 & 0 & 0 & 231 \\
\hline $8 / 20 / 09$ & 0 & 0 & 0 & 0 & 0 & 0 & N/A & 0 & 0 & 0 & 0 & 232 \\
\hline $8 / 21 / 09$ & 0 & 0 & 0 & 0 & 0 & 0 & $\mathrm{~N} / \mathrm{A}$ & 0 & 0 & 0 & 0 & 233 \\
\hline $8 / 22 / 09$ & 0.05 & 0.05 & 1.32 & 1.40 & 2.08 & 6.22 & N/A & 1.65 & 14.53 & 1.93 & 0.20 & 234 \\
\hline 8/23/09 & 1.22 & 1.32 & 0.86 & 0.89 & 0.05 & 0 & N/A & 0.05 & 2.13 & 3.38 & 0 & 235 \\
\hline $8 / 24 / 09$ & 0.10 & 0.05 & 0 & 0 & 0 & 0.05 & N/A & 0 & 0.43 & 0 & 3.00 & 236 \\
\hline $8 / 25 / 09$ & 0.18 & 0.13 & 0 & 0 & 0 & 0.56 & N/A & 0.05 & 0 & 0.18 & 0 & 237 \\
\hline $8 / 26 / 09$ & 0 & 0 & 0 & 0 & 0 & 0 & N/A & 0 & 0 & 0 & 0 & 238 \\
\hline $8 / 27 / 09$ & 0 & 0 & 0 & 0 & 0 & 0 & N/A & 0 & 0 & 0 & 0 & 239 \\
\hline $8 / 28 / 09$ & 0 & 0 & 0 & 0 & 0 & 0 & N/A & 0 & 0 & 0 & 0 & 240 \\
\hline $8 / 29 / 09$ & 0 & 0 & 0 & 0 & 0 & 0 & N/A & 0 & 0 & 0 & 0 & 241 \\
\hline 8/30/09 & 0 & 0 & 0.03 & 0 & 0 & 0 & N/A & 0 & 0 & 0 & 0 & 242 \\
\hline $8 / 31 / 09$ & 0 & 0 & 0 & 0 & 0 & 0 & N/A & 0 & 0 & 0 & 0 & 243 \\
\hline $9 / 1 / 09$ & 0.10 & 0.08 & 0.36 & 0.38 & 0.46 & 5.41 & $\mathrm{~N} / \mathrm{A}$ & 11.13 & 2.72 & 0.94 & 0.08 & 244 \\
\hline $9 / 2 / 09$ & 0 & 0 & 0 & 0 & 0 & 0 & N/A & 0 & 0 & 0.03 & 0.25 & 245 \\
\hline 9/3/09 & 0 & 0 & 0.08 & 0.13 & 2.59 & 0.58 & N/A & 0.28 & 0 & 0 & 0 & 246 \\
\hline $9 / 4 / 09$ & 1.19 & 1.24 & 11.20 & 12.57 & 4.85 & 0 & N/A & 0 & 0 & 0 & 0 & 247 \\
\hline 9/5/09 & 2.06 & 2.39 & 21.59 & 22.50 & 31.22 & 5.64 & N/A & 2.03 & 7.59 & 1.14 & 0.91 & 248 \\
\hline $9 / 6 / 09$ & 0 & 0 & 0 & 0 & 0 & 0 & N/A & 0 & 0 & 0 & 0 & 249 \\
\hline 9/7/09 & 0 & 0 & 0 & 0 & 0 & 0 & N/A & 0 & 0 & 0 & 0 & 250 \\
\hline 9/8/09 & 0 & 0 & 0 & 0 & 0 & 0 & N/A & 0 & 0 & 0 & 0 & 251 \\
\hline 9/9/09 & 0 & 0.03 & 0 & 0 & 0 & 0.13 & N/A & 0 & 0 & 0 & 0 & 252 \\
\hline
\end{tabular}


Table 2. (continued)

\begin{tabular}{|c|c|c|c|c|c|c|c|c|c|c|c|c|}
\hline Date & AZ C:05:0031 L & AZ C:05:0031 U & AZ C:13:0365 L & AZ C:13:0365 U & AZ C:13:0006 & AZ C:13:0336 U & AZ C:13:0346 L & AZ C:13:0346 U & AZ B:11:0281 & AZ A:15:0033 & AZ G:03:0072 U & Year Day \\
\hline 9/10/09 & 1.60 & 1.37 & 0.10 & 0.08 & 0.05 & 0 & N/A & 0.10 & 0 & 0 & 0 & 253 \\
\hline 9/11/09 & 0 & 0 & 0 & 0 & 0 & 0 & N/A & 0 & 0 & 0 & 0 & 254 \\
\hline 9/12/09 & 0 & 0 & 0 & 0 & 0 & 3.18 & N/A & 5.08 & 0 & 0.08 & 0 & 255 \\
\hline $9 / 13 / 09$ & 4.47 & 3.66 & 2.39 & 2.69 & 0.30 & 0.86 & $\mathrm{~N} / \mathrm{A}$ & 4.06 & 0.03 & 0 & 0 & 256 \\
\hline 9/14/09 & 0 & 0 & 0 & 0 & 0 & 0 & N/A & 0 & 0 & 0 & 0 & 257 \\
\hline 9/15/09 & 0 & 0 & 0 & 0 & 0 & 0 & N/A & 0 & 0 & 0 & 0 & 258 \\
\hline 9/16/09 & 0 & 0 & 0 & 0 & 1.93 & 0 & $\mathrm{~N} / \mathrm{A}$ & 0.03 & 0 & 0 & 0 & 259 \\
\hline 9/17/09 & 0 & 0 & 0 & 0 & 0 & 0 & $\mathrm{~N} / \mathrm{A}$ & 0 & 0 & 0 & 0 & 260 \\
\hline $9 / 18 / 09$ & 0 & 0 & 0 & 0 & 0 & 0 & N/A & 0 & 0 & 0 & 1.37 & 261 \\
\hline 9/19/09 & 0.69 & 0.58 & 0 & 0 & 0 & 0.15 & N/A & 0.36 & 0.05 & 0.23 & 0.05 & 262 \\
\hline 9/20/09 & 0 & 0 & 0 & 0 & 0 & 0 & N/A & 0 & 0 & 0 & 0 & 263 \\
\hline 9/21/09 & 0 & 0 & 0 & 0 & 0 & 0 & N/A & 0 & 0 & 0 & 0 & 264 \\
\hline 9/22/09 & 0 & 0 & 0 & 0 & 0 & 0 & $\mathrm{~N} / \mathrm{A}$ & 0 & 0 & 0 & 0 & 265 \\
\hline 9/23/09 & 0 & 0 & 0 & 0 & 0 & 0 & $\mathrm{~N} / \mathrm{A}$ & 0 & 0 & 0 & 0 & 266 \\
\hline 9/24/09 & 0 & 0 & 0 & 0 & 0 & 0 & N/A & 0 & 0 & 0 & 0 & 267 \\
\hline 9/25/09 & 0 & 0 & 0 & 0 & 0 & 0 & N/A & 0 & 0 & 0 & 0 & 268 \\
\hline 9/26/09 & 0 & 0 & 0 & 0.03 & 0 & 0 & N/A & 0 & 0 & 0 & 0 & 269 \\
\hline 9/27/09 & 0 & 0 & 0 & 0 & 0 & 0 & N/A & 0 & 0 & 0 & 0 & 270 \\
\hline 9/28/09 & 0 & 0 & 0 & 0 & 0 & 0 & N/A & 0 & 0 & 0 & 0 & 271 \\
\hline 9/29/09 & 0 & 0 & 0 & 0.03 & 0 & 0 & N/A & 0 & 0 & 0 & 0 & 272 \\
\hline 9/30/09 & 0 & 0 & 0 & 0.03 & 0.03 & 0 & $\mathrm{~N} / \mathrm{A}$ & 0 & 0 & 0 & 0 & 273 \\
\hline $\begin{array}{l}0 / 1 / 09 \\
\end{array}$ & 0 & 0 & 0 & 0 & 0 & 0 & N/A & 0 & 0 & 0 & 0 & 274 \\
\hline $10 / 2 / 09$ & 0 & 0 & 0 & 0 & 0 & 0 & N/A & 0 & 0 & 0 & 0 & 275 \\
\hline $10 / 3 / 09$ & 0 & 0 & 0 & 0 & 0 & 0 & N/A & 0 & 0 & 0 & 0 & 276 \\
\hline $10 / 4 / 09$ & 0.03 & 0 & 0.10 & 0.28 & 0.03 & 0.05 & N/A & 0 & 0 & 0 & 0 & 277 \\
\hline $10 / 5 / 09$ & 0 & 0 & 0 & 0 & 0 & 0 & N/A & 0 & 0 & 0 & 0 & 278 \\
\hline 10/6/09 & 0 & 0 & 0 & 0 & 0 & 0 & N/A & 0 & 0 & 0 & 0 & 279 \\
\hline $10 / 7 / 09$ & 0.38 & 0.30 & 0.08 & 0.13 & 0.46 & 1.63 & N/A & 3.78 & 1.27 & 0 & 0 & 280 \\
\hline 10/8/09 & 0 & 0 & 0 & 0 & 0 & 0 & N/A & 0 & 0 & 0 & 0 & 281 \\
\hline $10 / 9 / 09$ & $N / A$ & $N / A$ & 0 & 0.03 & 0 & 0 & N/A & 0 & 0 & 0 & 0 & 282 \\
\hline $10 / 10 / 09$ & $\mathrm{~N} / \mathrm{A}$ & N/A & 0 & 0 & 0 & 0 & N/A & 0 & 0 & 0 & 0 & 283 \\
\hline $10 / 11 / 09$ & 0 & 0 & 0 & 0 & 0 & 0 & N/A & 0 & 0 & 0 & 0 & 284 \\
\hline $10 / 12 / 09$ & 0 & 0 & 0 & 0 & 0 & 0 & N/A & 0 & 0 & 0 & 0 & 285 \\
\hline $10 / 13 / 09$ & 0 & 0 & 0 & 0 & 0 & 0 & N/A & 0 & 0 & 0 & 0 & 286 \\
\hline $10 / 14 / 09$ & 0 & 0 & 0 & 0 & 0 & 0 & N/A & 0 & 0 & 0 & 0 & 287 \\
\hline $10 / 15 / 09$ & 0 & 0 & 0 & 0 & 0 & 0 & N/A & 0 & 0 & 0 & 0 & 288 \\
\hline $10 / 16 / 09$ & 0 & 0 & 0 & 0 & 0 & 0.05 & $\mathrm{~N} / \mathrm{A}$ & 0 & 0 & 0 & 0 & 289 \\
\hline $10 / 17 / 09$ & 0 & 0 & 0 & 0 & 0 & 0 & 0 & 0 & 0 & 0 & 0 & 290 \\
\hline $10 / 18 / 09$ & 0 & 0 & 0 & 0 & 0 & 0 & 0 & 0 & 0 & 0 & 0 & 291 \\
\hline $10 / 19 / 09$ & 0 & 0 & 0 & 0.03 & 0 & 0 & 0.03 & 0 & 0 & 0 & 0 & 292 \\
\hline $10 / 20 / 09$ & 0.08 & 0.08 & 1.24 & 1.50 & 1.60 & 0.15 & 0 & 0 & 1.60 & 0 & 0 & 293 \\
\hline $10 / 21 / 09$ & 0 & 0 & 0 & 0 & 0 & 0 & 0 & 0 & 0 & 0 & 0 & 294 \\
\hline
\end{tabular}


Table 2. (continued)

\begin{tabular}{|c|c|c|c|c|c|c|c|c|c|c|c|c|}
\hline Date & AZ C:05:0031 L & AZ C:05:0031 U & AZ C:13:0365 L & AZ C:13:0365 U & AZ C:13:0006 & AZ C:13:0336 U & AZ C:13:0346 L & AZ C:13:0346 U & AZ B:11:0281 & AZ A:15:0033 & AZ G:03:0072 U & Year Day \\
\hline 10/22/09 & 0 & 0 & 0 & 0 & 0 & 0 & 0 & 0 & 0 & 0 & 0 & 295 \\
\hline $10 / 23 / 09$ & 0 & 0 & 0 & 0 & 0 & 0 & 0.03 & 0 & 0 & 0 & 0 & 296 \\
\hline $10 / 24 / 09$ & 0 & 0 & 0 & 0 & 0 & 0 & 0 & 0 & 0 & 0 & 0 & 297 \\
\hline $10 / 25 / 09$ & 0 & 0 & 0 & 0 & 0 & 0 & 0 & 0 & 0 & 0 & 0 & 298 \\
\hline $10 / 26 / 09$ & 0 & 0 & 0 & 0.03 & 0 & 0 & 0 & 0 & 0 & 0 & 0 & 299 \\
\hline $10 / 27 / 09$ & 0 & 0 & 0 & 0 & 0 & 0 & 0 & 0 & 0 & 0 & 0 & 300 \\
\hline 10/28/09 & 0 & 0 & 0 & 0 & 0 & 0 & 0 & 0 & 0 & 0 & 0.05 & 301 \\
\hline 10/29/09 & 0 & 0 & 0 & 0 & 0 & 0 & 0 & 0 & 0 & 0 & 0 & 302 \\
\hline $10 / 30 / 09$ & 0 & 0 & 0 & 0 & 0 & 0 & 0 & 0 & 0 & 0 & 0 & 303 \\
\hline $10 / 31 / 09$ & 0 & 0 & 0 & 0 & 0 & 0 & 0 & 0 & 0 & 0 & 0 & 304 \\
\hline 11/1/09 & 0 & 0 & 0 & 0 & 0 & 0 & 0 & 0 & 0 & 0.03 & 0 & 305 \\
\hline 11/2/09 & 0 & 0 & 0 & 0 & 0 & 0 & 0 & 0 & 0 & 0 & 0 & 306 \\
\hline $11 / 3 / 09$ & 0 & 0 & 0.03 & 0.03 & 0 & 0 & 0.03 & 0 & 0 & 0 & 0.03 & 307 \\
\hline $11 / 4 / 09$ & 0 & 0 & 0 & 0 & 0 & 0 & 0 & 0 & 0 & 0 & 0 & 308 \\
\hline $11 / 5 / 09$ & 0 & 0 & 0 & 0 & 0 & 0 & 0 & 0 & 0 & 0 & 0 & 309 \\
\hline $11 / 6 / 09$ & 0 & 0 & 0 & 0 & 0 & 0 & 0 & 0 & 0 & 0 & 0 & 310 \\
\hline $11 / 7 / 09$ & 0 & 0 & 0 & 0 & 0 & 0 & 0 & 0 & 0 & 0 & 0 & 311 \\
\hline $11 / 8 / 09$ & 0 & 0 & 0 & 0 & 0 & 0 & 0 & 0 & 0.03 & 0 & 0 & 312 \\
\hline $11 / 9 / 09$ & 0 & 0 & 0 & 0 & 0 & 0 & 0 & 0 & 0 & 0 & 0 & 313 \\
\hline 11/10/09 & 0 & 0 & 0 & 0 & 0 & 0 & 0 & 0 & 0 & 0 & 0 & 314 \\
\hline $11 / 11 / 09$ & 0 & 0 & 0 & 0 & 0 & 0 & 0 & 0 & 0 & 0 & 0 & 315 \\
\hline $11 / 12 / 09$ & 0 & 0 & 0 & 0 & 0 & 0 & 0 & 0 & 0 & 0 & 0 & 316 \\
\hline $11 / 13 / 09$ & 0.99 & 1.22 & 2.18 & 2.06 & 1.52 & 0.94 & 1.37 & 1.50 & 3.78 & 0.08 & 2.41 & 317 \\
\hline $11 / 14 / 09$ & 0.48 & 0.38 & 0.05 & 0.05 & 0.08 & 0.18 & 0.08 & 0.10 & 2.62 & 0.74 & 0.03 & 318 \\
\hline $11 / 15 / 09$ & 0 & 0 & 0 & 0 & 0 & 0 & 0 & 0 & 0 & 0 & 0 & 319 \\
\hline 11/16/09 & 0 & 0 & 0 & 0 & 0 & 0 & 0 & 0 & 0 & 0 & 0 & 320 \\
\hline $11 / 17 / 09$ & 0 & 0 & 0 & 0 & 0 & 0 & 0 & 0 & 0 & 0 & 0 & 321 \\
\hline $11 / 18 / 09$ & 0 & 0 & 0 & 0 & 0 & 0 & 0 & 0 & 0 & 0 & 0 & 322 \\
\hline $11 / 19 / 09$ & 0 & 0 & 0 & 0 & 0 & 0 & 0 & 0 & 0 & 0 & 0 & 323 \\
\hline $11 / 20 / 09$ & 0 & 0 & 0 & 0 & 0 & 0 & 0 & 0 & 0 & 0 & 0 & 324 \\
\hline $11 / 21 / 09$ & 0 & 0 & 0 & 0 & 0 & 0 & 0 & 0 & 0 & 0 & 0 & 325 \\
\hline $11 / 22 / 09$ & 0 & 0 & 0 & 0 & 0 & 0 & 0 & 0 & 0 & 0 & 0 & 326 \\
\hline $11 / 23 / 09$ & 0.05 & 0 & 0 & 0 & 0 & 0 & 0 & 0 & 0 & 0 & 0 & 327 \\
\hline $11 / 24 / 09$ & 0 & 0 & 0 & 0 & 0 & 0 & 0 & 0 & 0 & 0 & 0 & 328 \\
\hline $11 / 25 / 09$ & 0 & 0 & 0 & 0 & 0 & 0 & 0 & 0 & 0 & 0.03 & 0 & 329 \\
\hline 11/26/09 & 0 & 0 & 0 & 0 & 0 & 0 & 0.03 & 0 & 0 & 0 & 0 & 330 \\
\hline $11 / 27 / 09$ & 0 & 0 & 0 & 0 & 0 & 0 & 0 & 0 & 0 & 0 & 0 & 331 \\
\hline $11 / 28 / 09$ & 0.05 & 0.05 & 0.46 & 0.41 & 0.61 & 1.50 & 0.56 & 0.56 & 0 & 0 & 0 & 332 \\
\hline $11 / 29 / 09$ & 0.03 & 0 & 0.56 & 0.56 & 0.74 & 1.42 & 1.52 & 1.68 & 0.30 & 0 & 0 & 333 \\
\hline $11 / 30 / 09$ & 0 & 0 & 0 & 0 & 0 & 0 & 0 & 0 & 0 & 0 & 0 & 334 \\
\hline $12 / 1 / 09$ & 0 & 0 & 0 & 0 & 0 & 0 & 0 & 0 & 0 & 0 & 0 & 335 \\
\hline $12 / 2 / 09$ & 0 & 0 & 0 & 0 & 0 & 0 & 0 & 0 & 0 & 0 & 0 & 336 \\
\hline
\end{tabular}


Table 2. (continued)

\begin{tabular}{|c|c|c|c|c|c|c|c|c|c|c|c|c|}
\hline Date & AZ C:05:0031 L & AZ C:05:0031 U & AZ C:13:0365 L & AZ C:13:0365U & AZ C:13:0006 & AZ C:13:0336 U & AZ C:13:0346 L & AZ C:13:0346 U & AZ B:11:0281 & AZ A:15:0033 & AZ G:03:0072 U & Year Day \\
\hline $12 / 3 / 09$ & 0 & 0 & 0 & 0 & 0 & 0 & 0 & 0 & 0 & 0 & 0 & 337 \\
\hline $12 / 4 / 09$ & 0 & 0 & 0 & 0 & 0 & 0 & 0 & 0 & 0 & 0 & 0 & 338 \\
\hline $12 / 5 / 09$ & 0 & 0 & 0 & 0 & 0 & 0 & 0 & 0 & 0 & 0 & 0 & 339 \\
\hline $12 / 6 / 09$ & 0 & 0 & 0 & 0 & 0 & 0.03 & 0 & 0 & 0 & 0 & 0 & 340 \\
\hline $12 / 7 / 09$ & 12.34 & 10.85 & 27.46 & 24.36 & 30.96 & 26.54 & 24.79 & 27.66 & 20.57 & 30.89 & 19.86 & 341 \\
\hline $12 / 8 / 09$ & 3.23 & 2.72 & 6.43 & 5.59 & 5.03 & 3.58 & 2.54 & 2.11 & 0.05 & 0.36 & 0.05 & 342 \\
\hline $12 / 9 / 09$ & 0 & 0 & 0 & 0 & 0 & 0 & 0 & 0 & 0 & 0 & 0 & 343 \\
\hline $12 / 10 / 09$ & 0 & 0 & 0 & 0.03 & 0 & 0 & 0 & 0 & 0 & 0 & 0 & 344 \\
\hline $12 / 11 / 09$ & 0 & 0 & 0 & 0 & 0 & 0 & 0 & 0 & 0.03 & 0.91 & 0.08 & 345 \\
\hline $12 / 12 / 09$ & 0 & 0 & 0.10 & 0.08 & 0.05 & 0.46 & 0.25 & 0.23 & 4.37 & 3.53 & 0.13 & 346 \\
\hline $12 / 13 / 09$ & 2.13 & 1.98 & 7.24 & 6.30 & 7.19 & 3.91 & 4.78 & 6.22 & 6.88 & 4.50 & 2.54 & 347 \\
\hline $12 / 14 / 09$ & 0 & 0 & 0 & 0 & 0 & 0 & 0 & 0 & 0 & 0 & 0 & 348 \\
\hline $12 / 15 / 09$ & 0 & 0 & 0 & 0 & 0 & 0 & 0 & 0 & 0 & 0 & 0 & 349 \\
\hline $12 / 16 / 09$ & 0 & 0 & 0 & 0 & 0 & 0 & 0 & 0 & 0 & 0 & 0 & 350 \\
\hline $12 / 17 / 09$ & 0 & 0 & 0 & 0 & 0 & 0 & 0 & 0 & 0 & 0 & 0 & 351 \\
\hline $12 / 18 / 09$ & 0 & 0 & 0 & 0 & 0 & 0 & 0 & 0 & 0 & 0 & 0 & 352 \\
\hline $12 / 19 / 09$ & 0 & 0 & 0 & 0 & 0 & 0 & 0 & 0 & 0 & 0 & 0 & 353 \\
\hline $12 / 20 / 09$ & 0 & 0 & 0 & 0 & 0 & 0 & 0 & 0 & 0 & 0 & 0 & 354 \\
\hline $12 / 21 / 09$ & 0 & 0 & 0 & 0 & 0 & 0 & 0 & 0 & 0 & 0.05 & 0.03 & 355 \\
\hline $12 / 22 / 09$ & 1.12 & 1.12 & 10.34 & 9.07 & 12.24 & 12.93 & 10.64 & 12.73 & 11.15 & 9.02 & 11.05 & 356 \\
\hline $12 / 23 / 09$ & 0 & 0 & 0 & 0 & 0.03 & 0.05 & 0.18 & 0.05 & 0 & 0.03 & 0.36 & 357 \\
\hline $12 / 24 / 09$ & 0 & 0 & 0 & 0 & 0 & 0 & 0 & 0 & 0 & 0 & 0 & 358 \\
\hline $12 / 25 / 09$ & 0 & 0 & 0 & 0 & 0 & 0 & 0 & 0 & 0 & 0 & 0 & 359 \\
\hline $12 / 26 / 09$ & 0 & 0 & 0 & 0 & 0 & 0 & 0 & 0 & 0 & 0 & 0 & 360 \\
\hline $12 / 27 / 09$ & 0 & 0 & 0 & 0 & 0 & 0 & 0 & 0 & 0 & 0 & 0 & 361 \\
\hline $12 / 28 / 09$ & 0 & 0 & 0 & 0 & 0 & 0 & 0 & 0 & 0 & 0 & 0 & 362 \\
\hline $12 / 29 / 09$ & 0 & 0 & 0 & 0 & 0 & 0 & 0 & 0 & 0 & 0 & 0 & 363 \\
\hline $12 / 30 / 09$ & 0 & 0 & 0.08 & 0.03 & 0.08 & 0.15 & 0.08 & 0.10 & 5.46 & 0.51 & 0.08 & 364 \\
\hline $12 / 31 / 09$ & 0 & 0 & 0 & 0 & 0 & 0 & 0 & 0 & 0 & 0 & 0 & 365 \\
\hline
\end{tabular}


Table 3. Vector sums of the sediment-transport proxy variable, $Q p$ (equation 1), by month for each weather station. Vector sums are reported as the magnitude of $Q p$ (in $\mathrm{m}^{3} \mathrm{~s}^{-3}$ ) followed by the direction from which this net transport would occur, in degrees. $A$, vector sums for all months at all stations where mostly complete months of data are available. These calculations were made irrespective of rain events. $B$, vector sums re-calculated using wind data collected only when sand is assumed to have been dry enough to transport sand. These calculations omit wind data collected within 48 hours after a rain event.

\begin{tabular}{|c|c|c|c|c|c|c|c|c|c|c|c|c|}
\hline \multirow[b]{2}{*}{ Station } & \multicolumn{12}{|c|}{ Vector sums, $Q p$ (equation 1 ) in $\mathrm{m} 3 / \mathrm{s} 3$; degrees } \\
\hline & Jan-09 & Feb-09 & Mar-09 & Apr-09 & May-09 & Jun-09 & Jul-09 & Aug-09 & Sep-09 & Oct-09 & Nov-09 & Dec-09 \\
\hline AZC:05:0031 L & $257 \quad 217$ & & & דר2 1156 & 110 & & & & & & & \\
\hline AZ C:05:0031 U & 602233 & 2811235 & 242 & 142243 & & 17252 & $=234$ & 252 & & & & \\
\hline AZ C: $13: 0365 \mathrm{~L}$ & 22687 & 2011,200 & & 157 & & & & & & & & 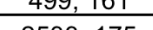 \\
\hline AZ C:13:0365U & 8025,111 & 104 & & 071270,124 & & & & 151 & $\frac{7,24}{0.110}$ & & & $2533,1 / 5$ \\
\hline AZ C:13:0006 & 1554,143 & & 170 & & & & & & & 0,100 & 140 & \\
\hline AZ C: $13: 0336 \mathrm{U}$ & 4701 & 121 & 112 & & & & & & & & & 144 \\
\hline AZ C:13:0346 L & 26700 & 850 & 118. & & & & & & & & & 124 \\
\hline AZ C:13:0346 U & 25759,229 & & 100 & & & & & & & & & 239 \\
\hline AZ B: $11: 0281$ & 430,243 & & 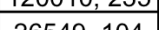 & & & & & & & & & 5,215 \\
\hline AZA:15:0033 & 10473,351 & & & & & & & & & & & $\frac{5,23}{300}$ \\
\hline AZ G:03:0072U & 681,65 & 3363,182 & 8570128 & 20253,182 & 4269178 & 11700181 & 10557.188 & 9100185 & 5852181 & 169 & $\frac{4414,050}{832,177}$ & 329 \\
\hline
\end{tabular}

\begin{tabular}{|c|c|c|c|c|c|c|c|c|c|c|c|c|}
\hline \multirow[b]{2}{*}{ Station } & \multicolumn{12}{|c|}{ Vector sums, Qp (equation 1 ) in $\mathrm{m} 3 / \mathrm{s} 3$; deqrees } \\
\hline & Jan-09 & Feb-09 & Mar-09 & Apr-09 & May-09 & Jun-09 & Jul-09 & Aug-09 & Sep-09 & Oct-09 & Nov-09 & Dec-09 \\
\hline AZC.05.0031L L & 385,1 & 130.23 & 10178,222 & 11552,229 & 682.137 & 1308,196 & 383,150 & 143,260 & 2467,182 & 1461,168 & 122,138 & 371,90 \\
\hline AZ C:05:0031 U & 72,99 & 1148,234 & 27250,244 & 30331,244 & 3718,224 & 2565,247 & 3213,242 & 2145,248 & 6819,246 & 7990,249 & 650,221 & 177,144 \\
\hline AZ C:13:0365 L & 2581,6 & 1259,124 & 18950,160 & 15273,158 & 1230,137 & 4899,148 & 1037,175 & 490,49 & 3419,27 & 542,352 & 343,321 & 771,186 \\
\hline AZ C:13:0365 U & 1623,79 & 9637,124 & 59634,123 & 121380,126 & 39250,133 & 94147,150 & 49304,152 & 18738,151 & 17796,147 & 58556,152 & 19340,152 & 28352,154 \\
\hline AZ C:13:0006 & 310,162 & 2331,66 & 20278,128 & 21260,130 & 2201,53 & 4881,141 & 1365,108 & 856,121 & 5433,129 & 4733,129 & 1592,141 & 2877,145 \\
\hline AZ C:13:0336 U & 36179,37 & 16526,77 & 88153,159 & 89804,165 & 39302,168 & 47194,167 & 39194,165 & 11735,170 & 17560,145 & 49975,145 & 40620,38 & 28394,91 \\
\hline AZ C:13:0346 L & 11281,253 & 12112,250 & 53938,252 & 64841,256 & 31174,251 & $\mathrm{~N} / \mathrm{A}$ & N/A & N/A & N/A & N/A & 15664,242 & 46708,244 \\
\hline AZ C:13:0346 U & 6376,243 & 14370,229 & 75663,236 & 101780,242 & 19786,238 & 29890,242 & 20119,232 & 7986,234 & 14193,237 & 44633,235 & 10245,221 & 25345,231 \\
\hline AZ B:11:0281 & 404,250 & 2599,87 & 32155,104 & 26254,96 & 2645,84 & 18112,96 & 7551,94 & 899,22 & 5525,103 & 27012,95 & 1547,103 & 2931,97 \\
\hline AZ A:15:0033 & 10623,352 & 1972,346 & 1946,207 & 4130,199 & 279,26 & 2649,192 & 1775,191 & 1327,192 & 132,168 & 18403,200 & 2430,355 & 1334,342 \\
\hline AZ G:03:0072 U & 1184,32 & 1271,180 & 8049,123 & 19283,183 & 3888,182 & 10696,181 & 4331,188 & 6002,188 & 5688,184 & 10091,172 & 1114,201 & 336,139 \\
\hline
\end{tabular}




\section{Figures}

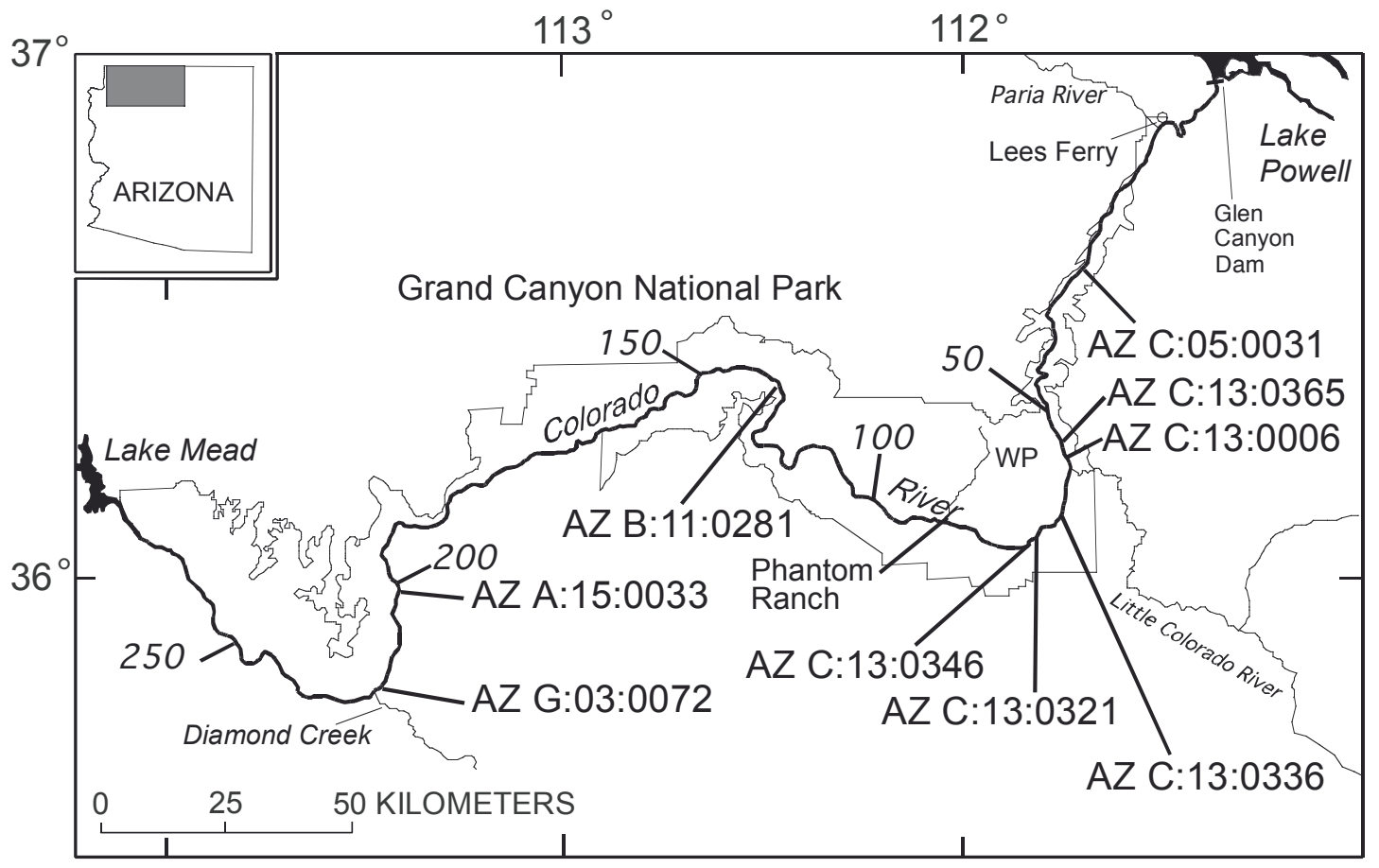

Figure 1. Colorado River corridor through Grand Canyon, Ariz., showing approximate locations of study sites. River reach between Lees Ferry and the Little Colorado River is known as Marble Canyon. WP indicates the location of the Walhalla Plateau, a promontory on the north rim of the canyon. Numbers in italics indicate river miles downstream of Lees Ferry. 


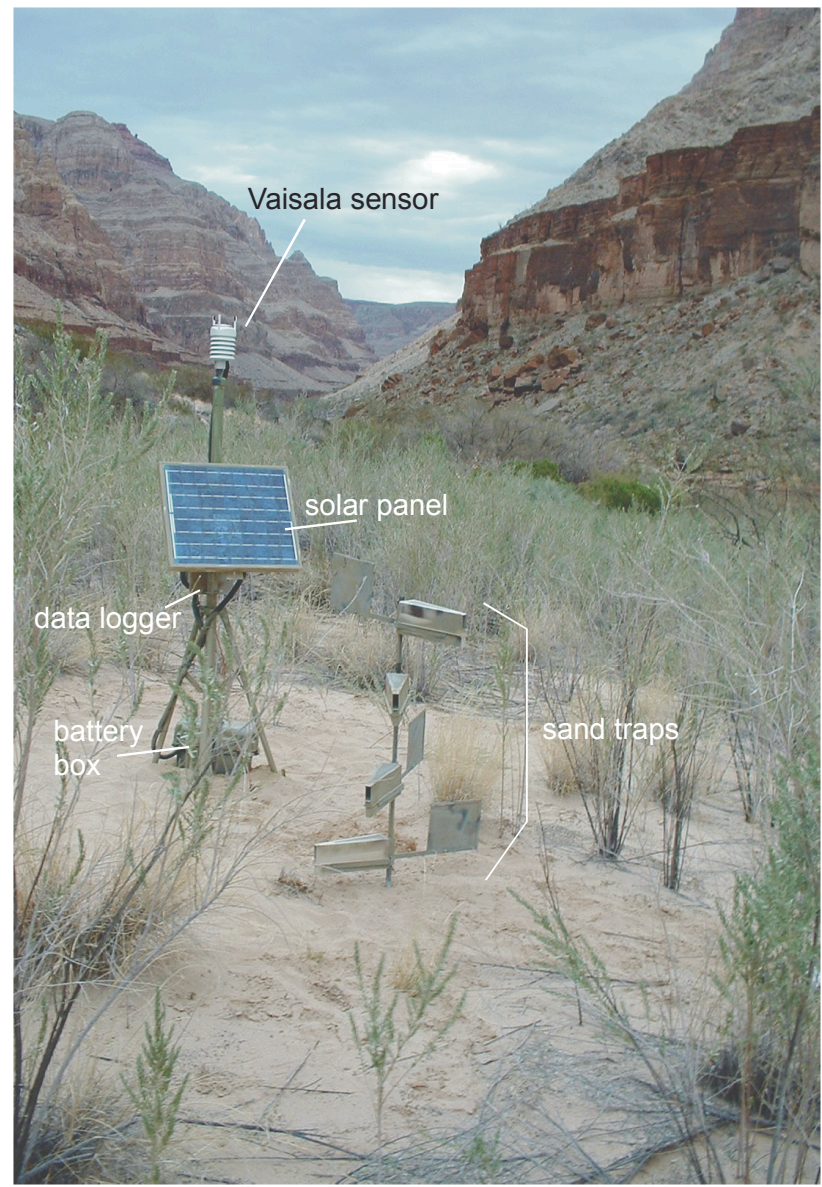

Figure 2. Photograph of instrument station near AZ A:15:0033. The sensor, data logger, and solar panel are mounted on a tripod (in this photograph, the data logger is behind the solar panel), and the system is powered by a battery housed in a box on the ground. The pole with four sand traps on it is approximately $3 \mathrm{~m}$ away from the tripod. 

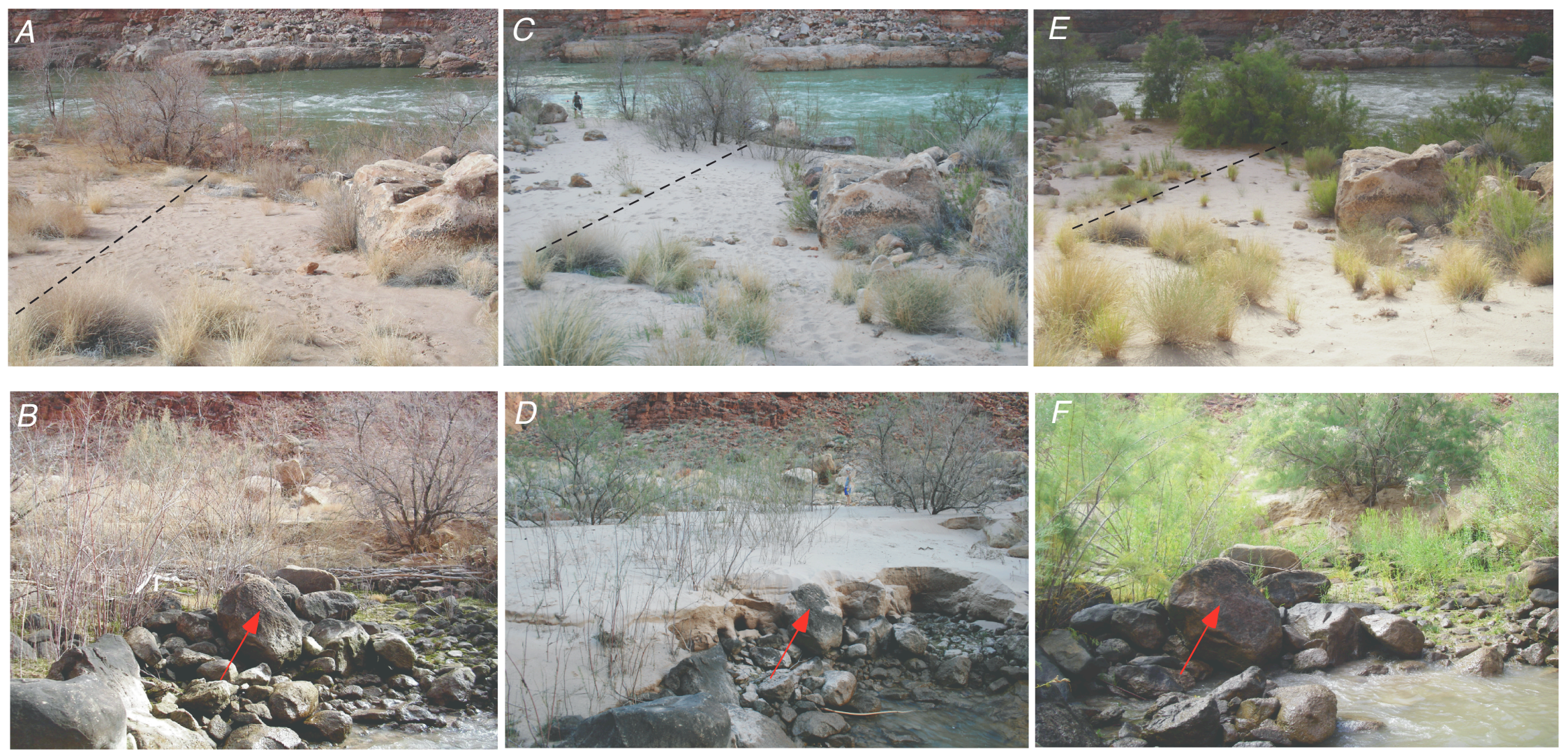

Figure 3. Photographs of the sandbar near AZ C:05:0031 before and after the 2008 High-Flow Experiment (HFE). $A$ and $B$ were taken on February 4, 2008; $C$ and $D$ were taken on March 29, 2008; $E$ and $F$ were taken on July 23, 2009. The red arrow on $B, D$, and $F$ points to the same rock. The area shown in $A, C$, and $E$ includes the shore-perpendicular Profile 2 plotted in figure 4 (dashed lines). 


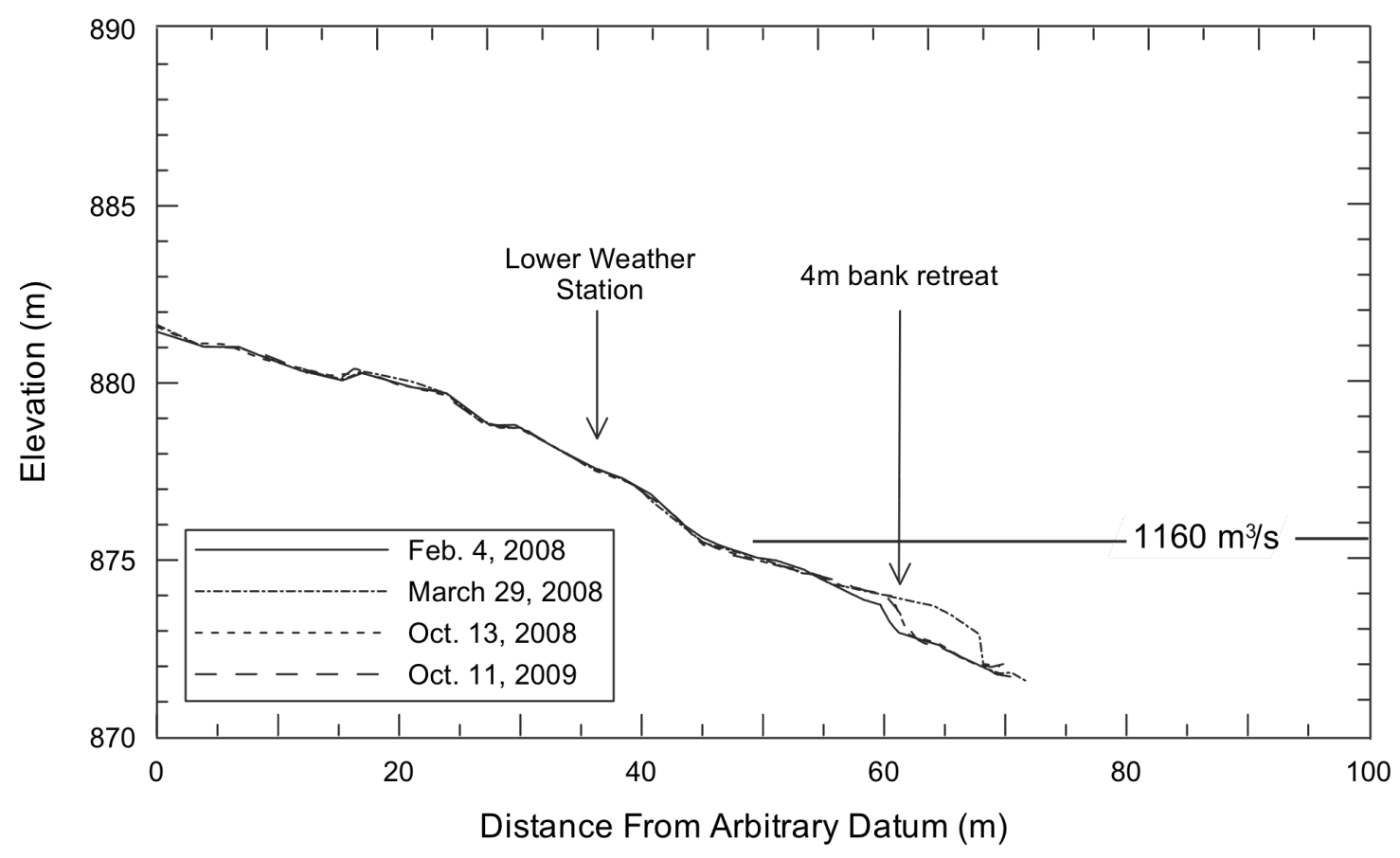

Figure 4. Surveyed profiles of the sandbar near AZ C:05:0031, in Grand Canyon, Ariz., before and after the 2008 High-Flow Experiment (HFE). Profiles trend east-southeast, approximately perpendicular to the channel margin (shown in fig. 3 by dashed line). The elevation of the HFE peak stage is indicated $\left(1,161 \mathrm{~m}^{3} / \mathrm{s}\right)$. 


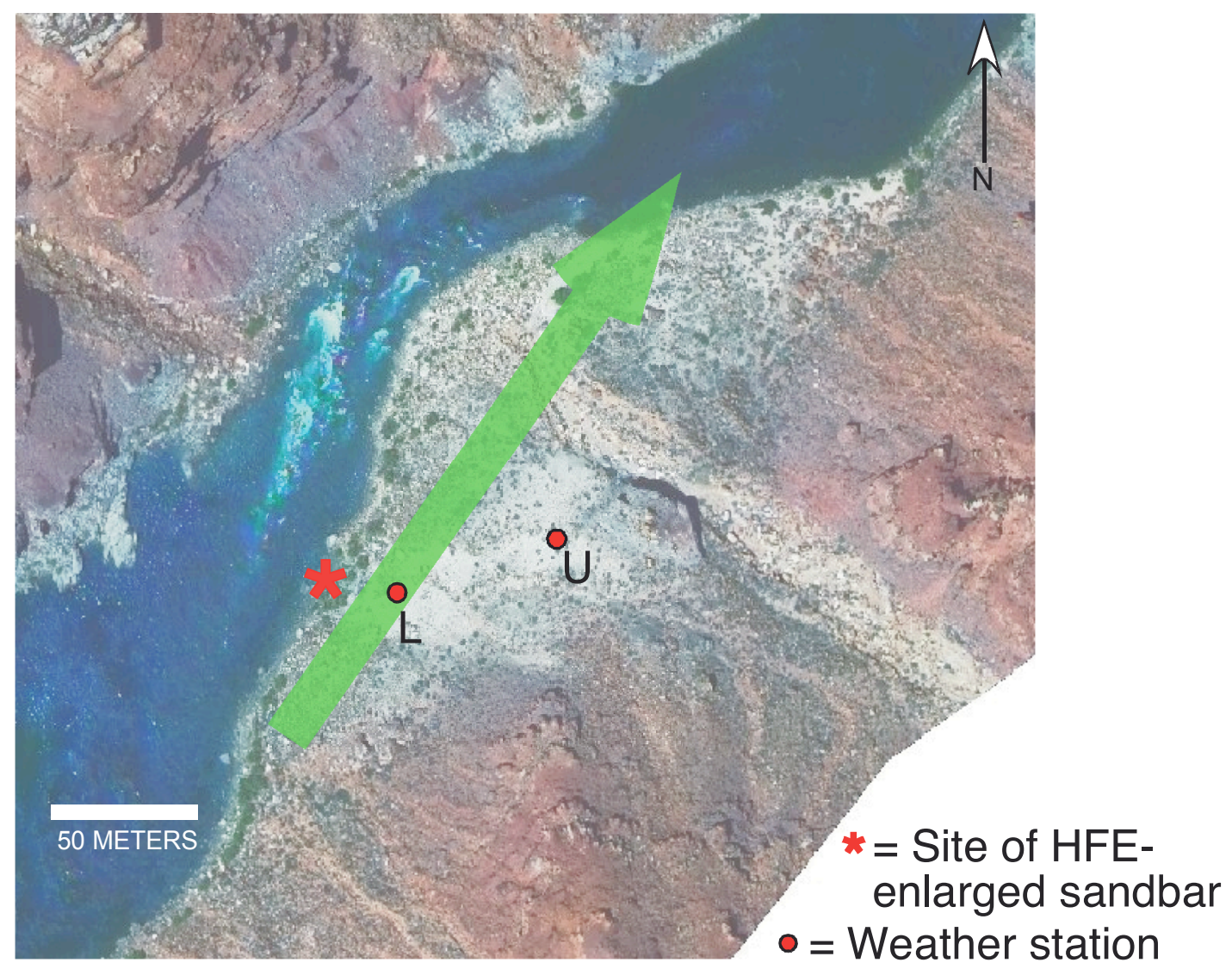

Figure 5. Aerial photograph of the area around AZ C:05:0031, in Grand Canyon, Ariz., with arrow indicating net direction of potential aeolian sediment transport measured at AZ C:05:0031 L in 2009. A vector sum of the $Q p$ proxy variable (equation 1 ), calculated using all wind data collected during dry conditions from AZ C:05:0031 L in 2009, indicates net sediment transport from $215^{\circ}$. 


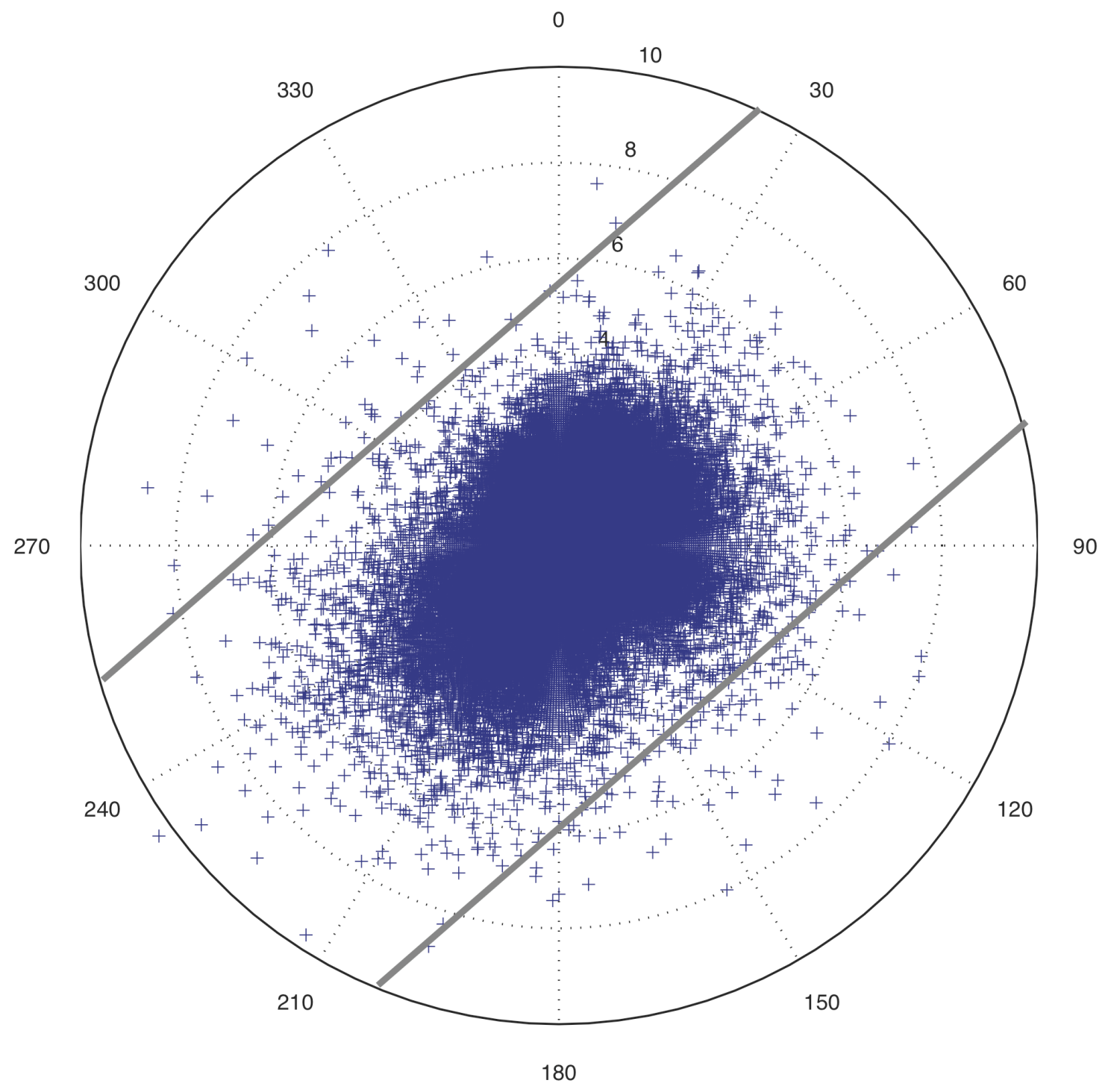

Figure 6. Magnitude and direction of wind velocity measured at the instrument station AZ C:05:0031 L in the Colorado River corridor, Grand Canyon, Ariz., at 4-minute resolution throughout 2009. Magnitude is indicated by the concentric circles, and compass bearing indicates direction from which the wind came. Parallel gray lines show the orientation of the canyon $\left(49^{\circ}\right)$; river flow is toward the southwest here. 
STATION AZ C:05:0031 L

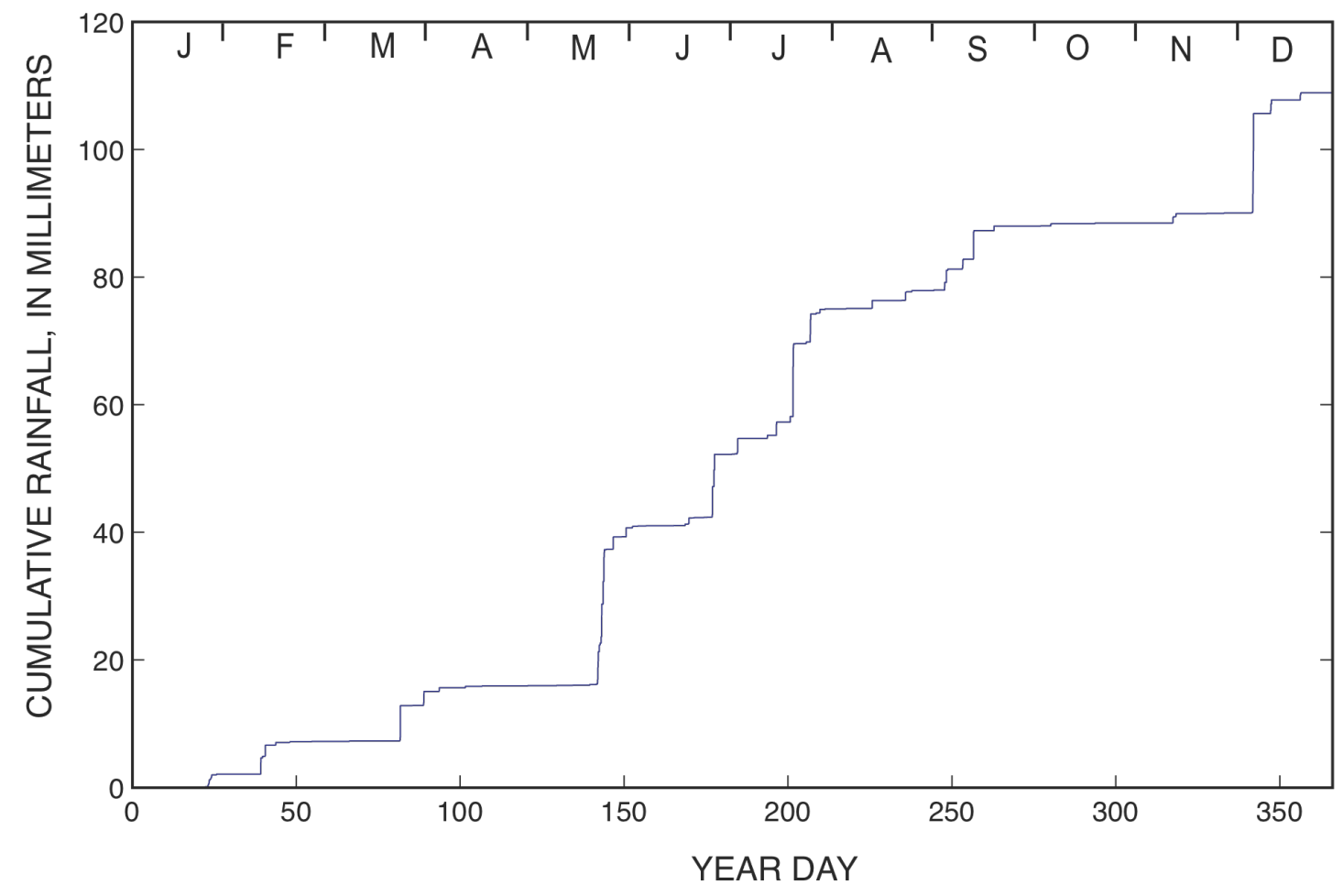

Figure 7. Cumulative 2009 rainfall record measured at AZ C:05:0031 L in the Colorado River corridor, Grand Canyon, Ariz., compiled from data collected at 4-minute resolution. 

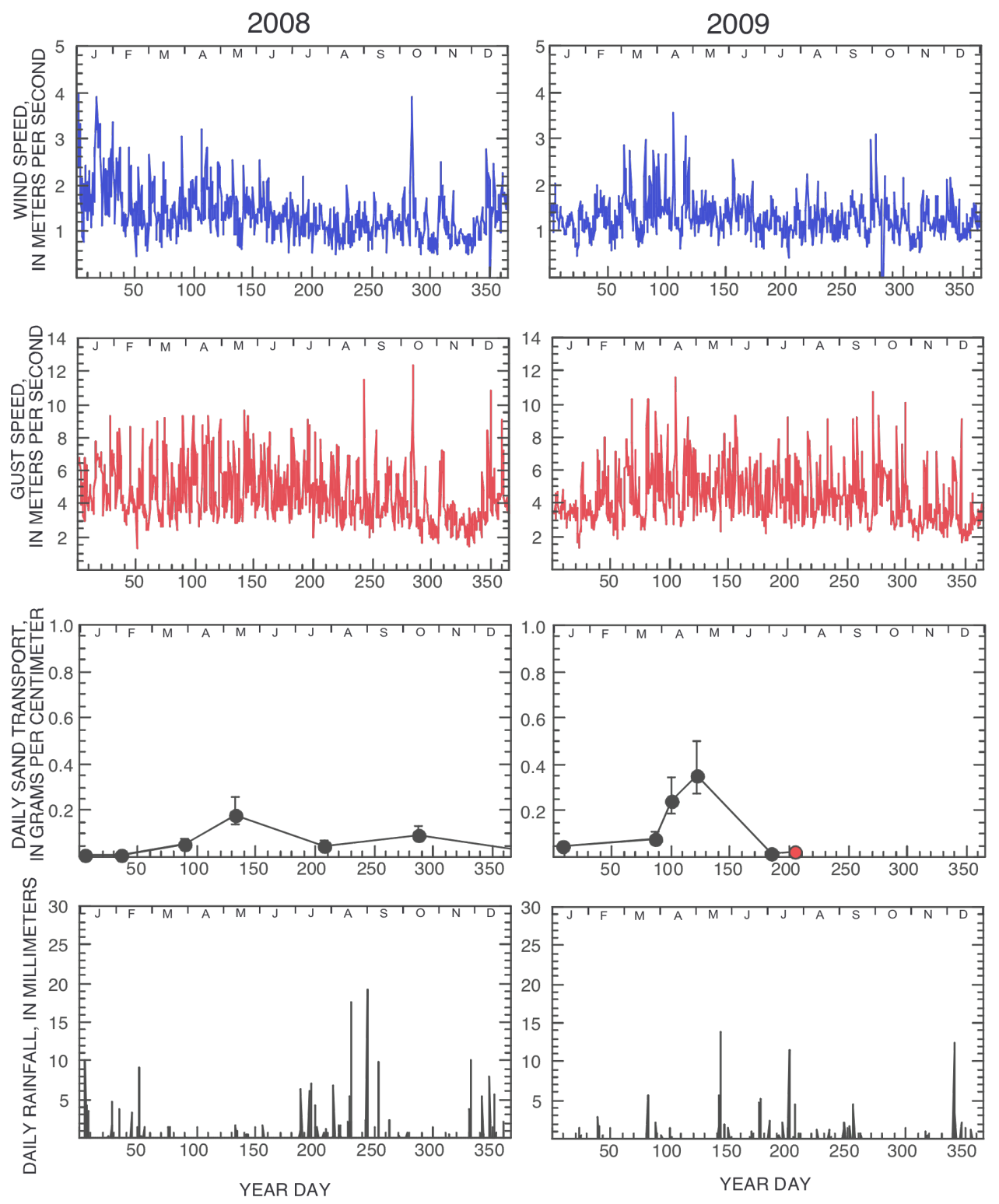

Figure 8. Wind, aeolian sand-transport, and rainfall data collected at the instrument station AZ C:05:0031 L in the Colorado River corridor, Grand Canyon, Ariz., in 2008 and 2009. Daily sand transport is plotted in grams, normalized to a width of $1 \mathrm{~cm}$. To obtain these values, total sand mass collected from four traps during each maintenance visit was divided by number of days since traps had last been emptied. The red data point in July is a minimum estimate only, made when one of the four sand traps at that site was discovered to have broken. Wind speed (blue plot), is presented as diurnal average values, using daytime (0600-1800 h) and nighttime (1800-0600 h) averages of data collected at 4-minute intervals. Gust speed (red plot) is shown as maximum values that occurred during each diurnal interval. Rainfall is plotted as daily (24-hour) totals. 

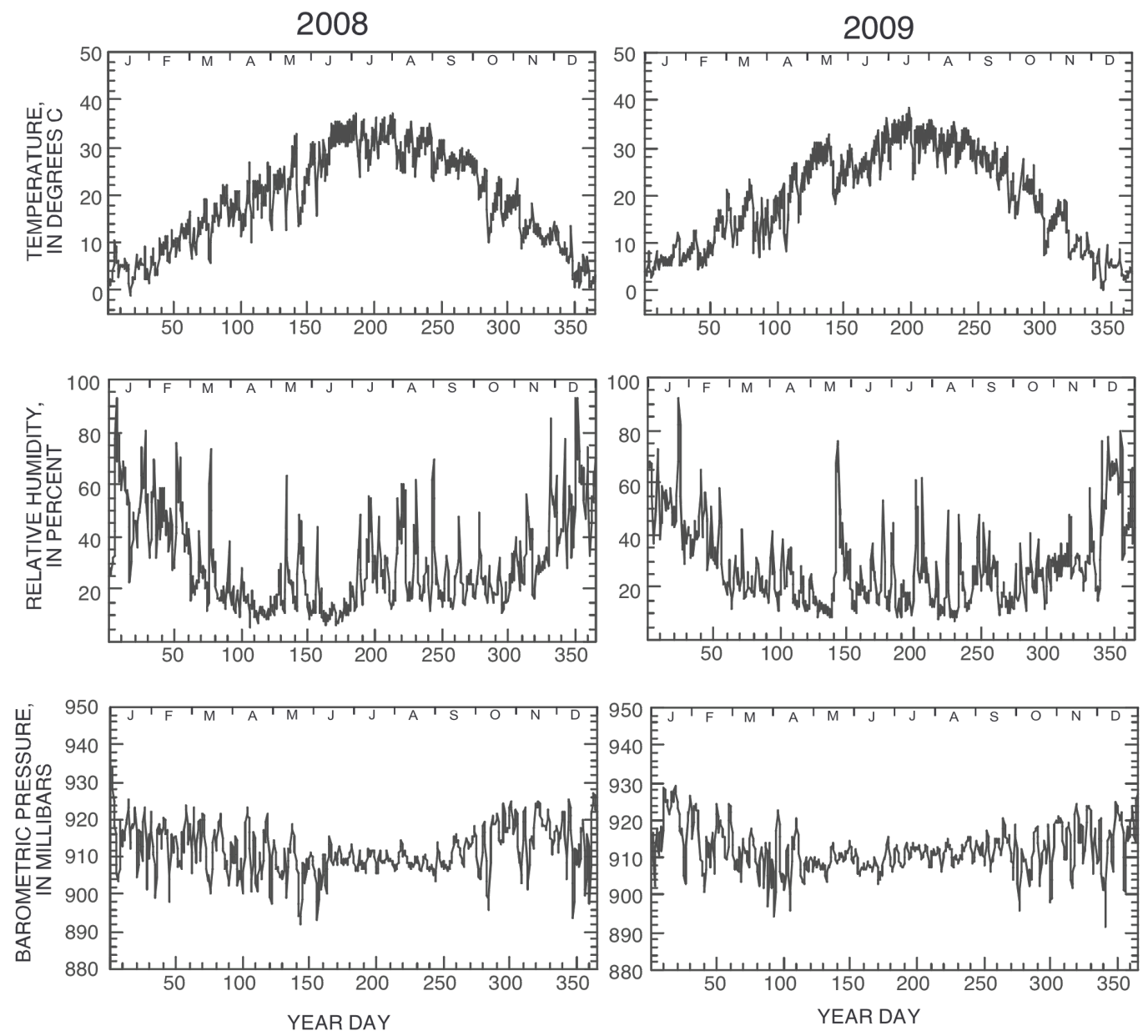

Figure 9. Temperature, humidity, and barometric pressure data collected at the instrument station AZ C:05:0031 L in the Colorado River corridor, Grand Canyon, Ariz., in 2008 and 2009. All parameters are plotted as diurnal averages (defined using 0600-1800 and 1800-0600 h). 


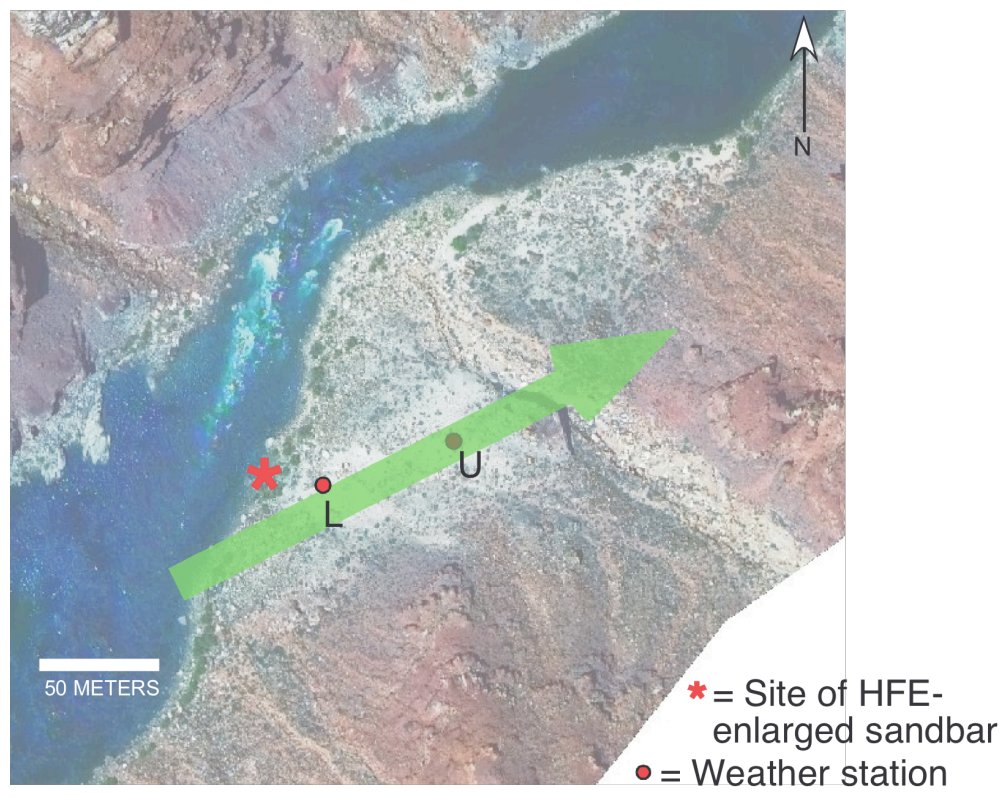

Figure 10. Aerial photograph of the area around AZ C:05:0031, in Grand Canyon, Ariz., with arrow indicating net direction of potential aeolian sediment transport measured at the instrument station AZ C:05:0031 $\mathrm{U}$ in 2009. A vector sum of the $Q p$ proxy variable (equation 1), calculated using all wind data collected during dry conditions from AZ $\mathrm{C}: 05: 0031 \mathrm{U}$ in 2009 , indicates net sediment transport from $243^{\circ}$. 


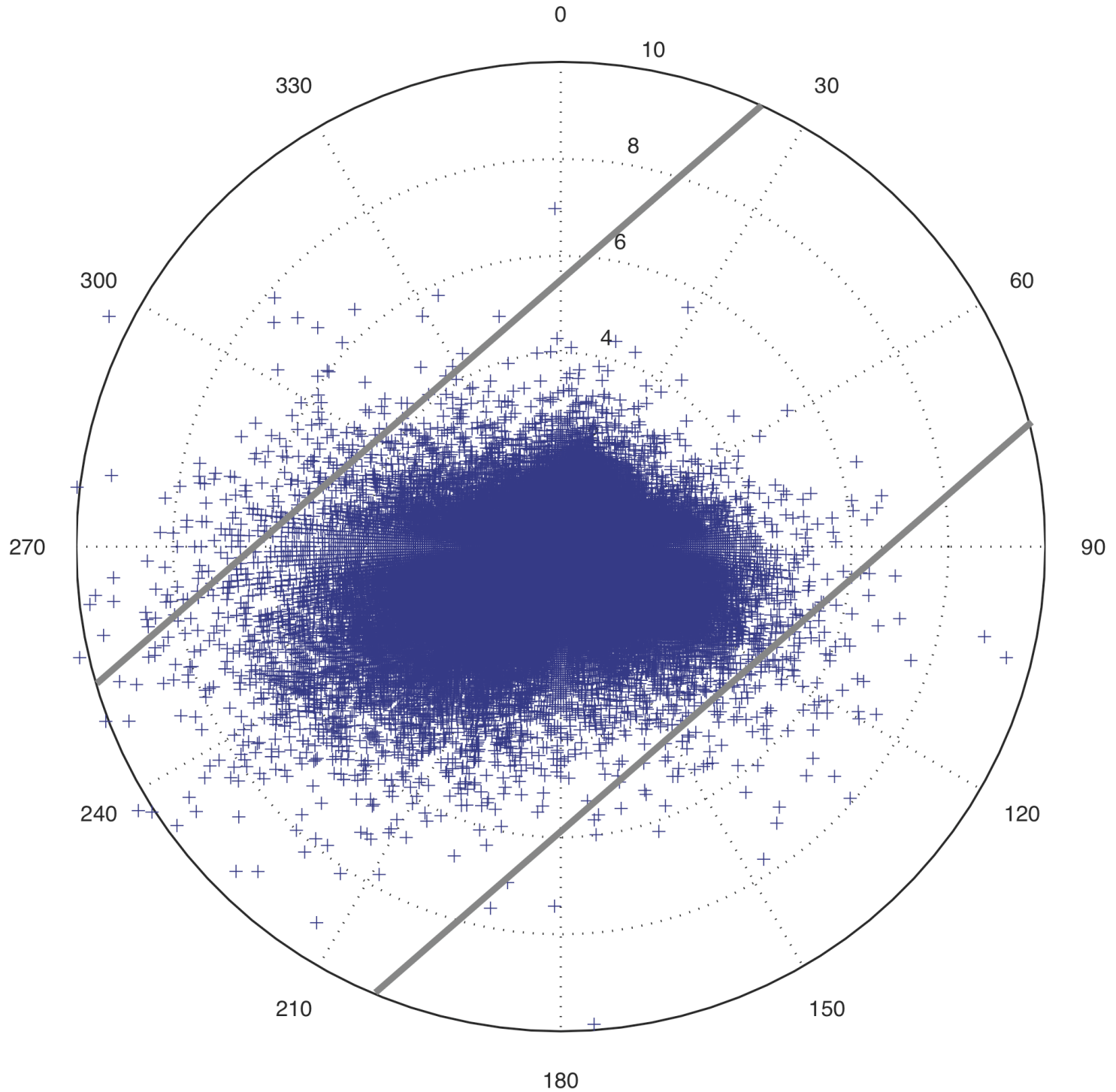

Figure 11. Magnitude and direction of wind velocity measured at the instrument station AZ C:05:0031 U in the Colorado River corridor, Grand Canyon, Ariz., at 4-minute resolution throughout 2009. Magnitude is indicated by the concentric circles, and compass bearing indicates direction from which the wind came. Parallel gray lines show the orientation of the canyon $\left(49^{\circ}\right)$; river flow is toward the southwest. 
STATION AZ C:05:0031 U

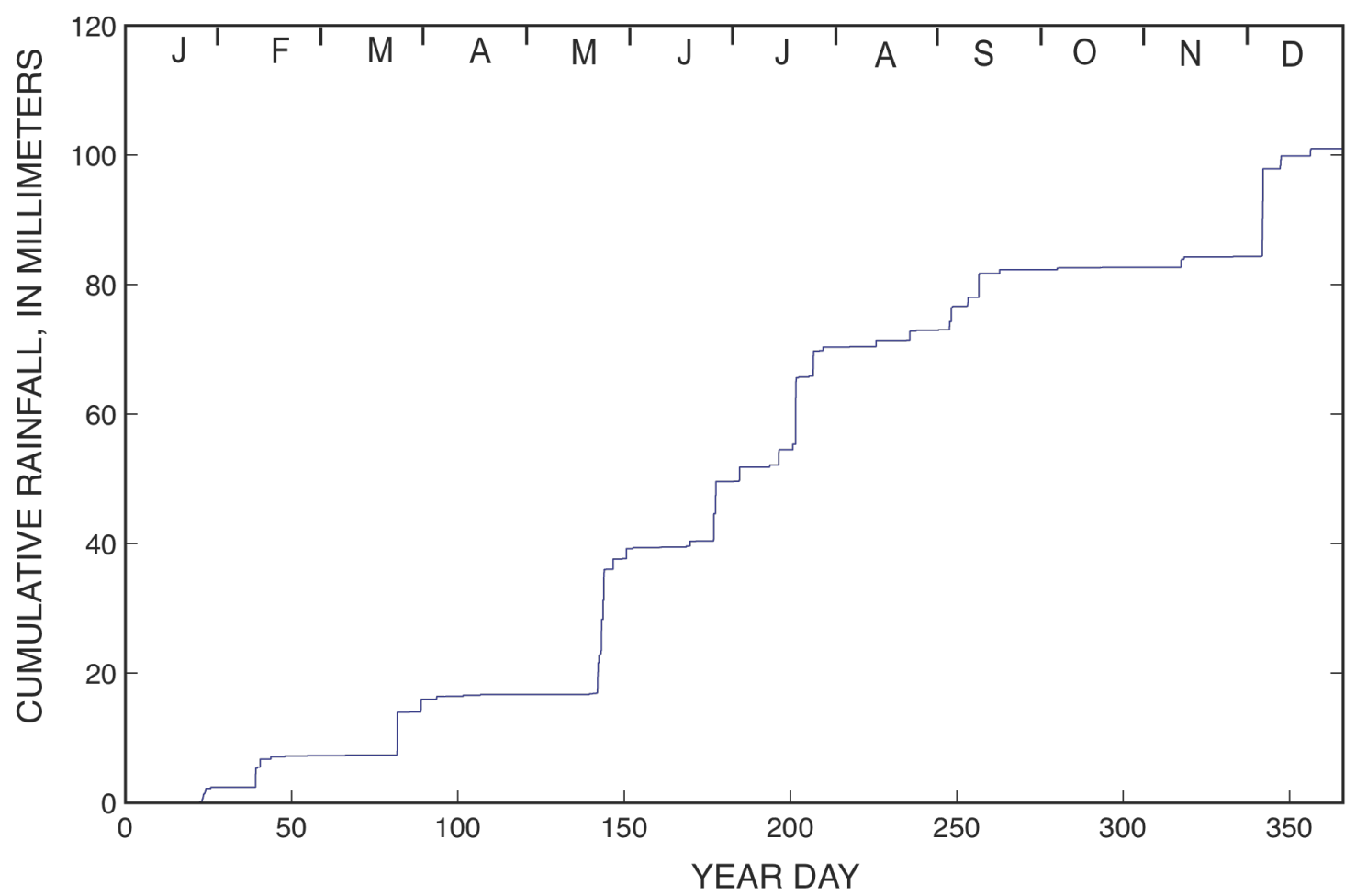

Figure 12. Cumulative 2009 rainfall record measured at AZ C:05:0031 U in the Colorado River corridor, Grand Canyon, Ariz., compiled from data collected at 4-minute resolution. 

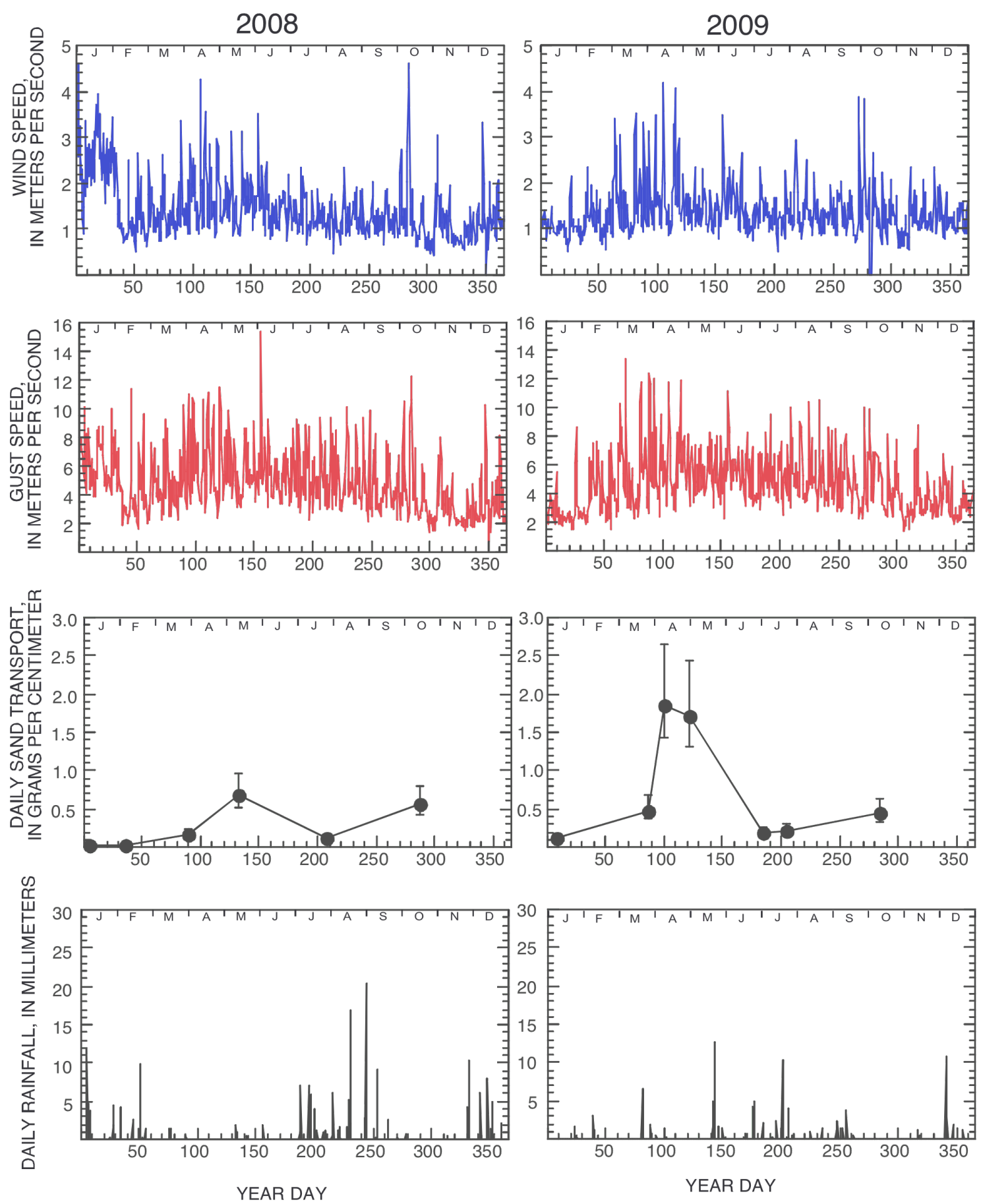

Figure 13. Wind, aeolian sand-transport, and rainfall data collected at the instrument station AZ C:05:0031 U in the Colorado River corridor, Grand Canyon, Ariz., in 2008 and 2009. Daily sand transport is plotted in grams, normalized to a width of $1 \mathrm{~cm}$. To obtain these values, total sand mass collected from four traps during each maintenance visit was divided by number of days since traps had last been emptied. Wind speed (blue plot) is presented as diurnal average values, using daytime $(0600-1800 \mathrm{~h})$ and nighttime $(1800-0600 \mathrm{~h})$ averages of data collected at 4-minute intervals. Gust speed (red plot) is 
shown as maximum values that occurred during each diurnal interval. Rainfall is plotted as daily (24-hour) totals.
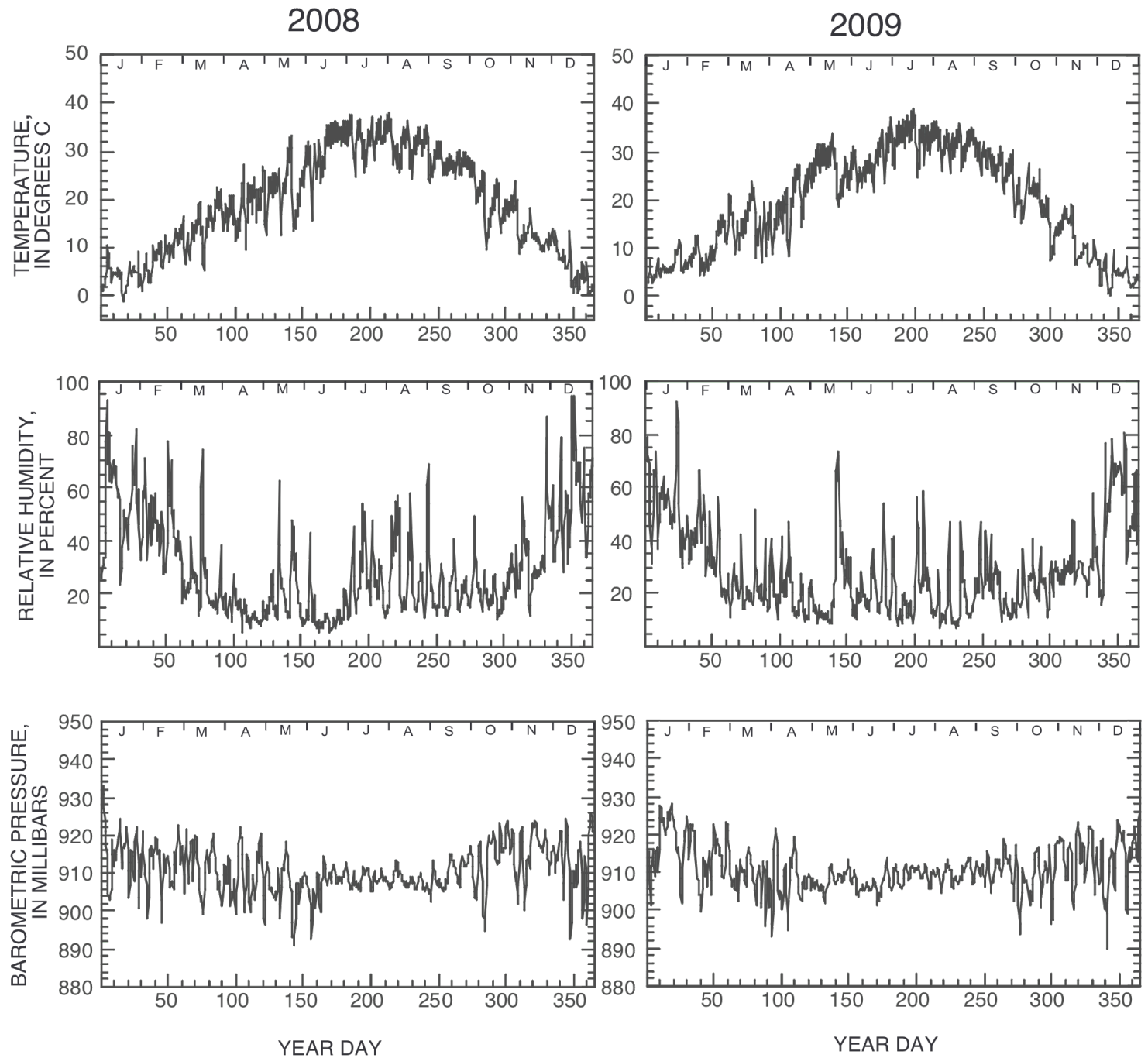

Figure 14. Temperature, humidity, and barometric pressure data collected at the instrument station AZ C:05:0031 U in the Colorado River corridor, Grand Canyon, Ariz., in 2008 and 2009. All parameters are plotted as diurnal averages (defined using 0600-1800 and $1800-0600$ hours). 

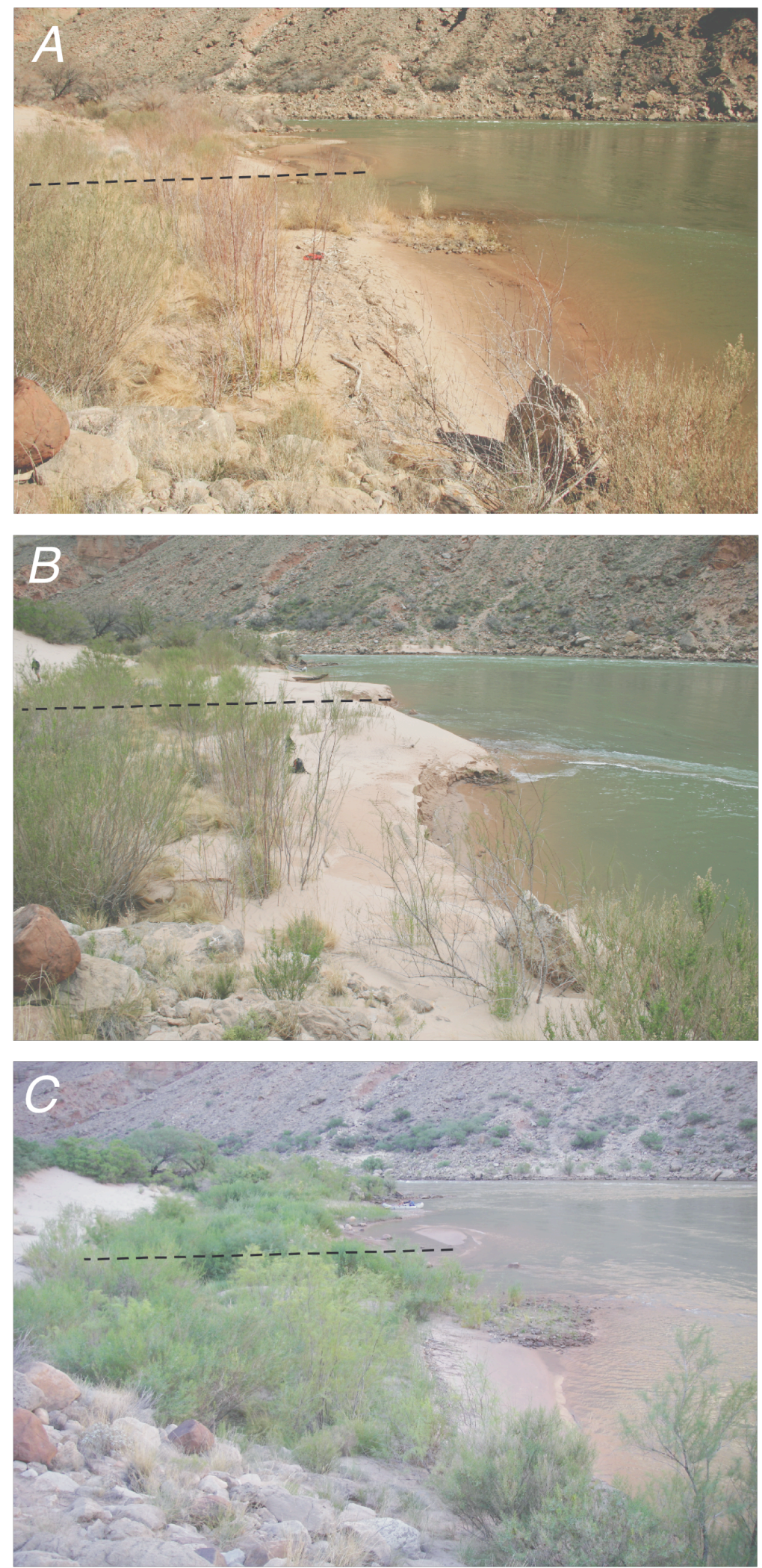

Figure 15. Photographs of the sandbar near AZ C:13:0365 before and after the March 2008 High-Flow Experiment (HFE). $A$ was taken on February 9, 2008; $B$ was taken on 
April 3, 2008; $C$ was taken on July 26, 2009. The dashed lines on each photograph indicate the locations of shore-perpendicular topographic profiles shown in figure 17.
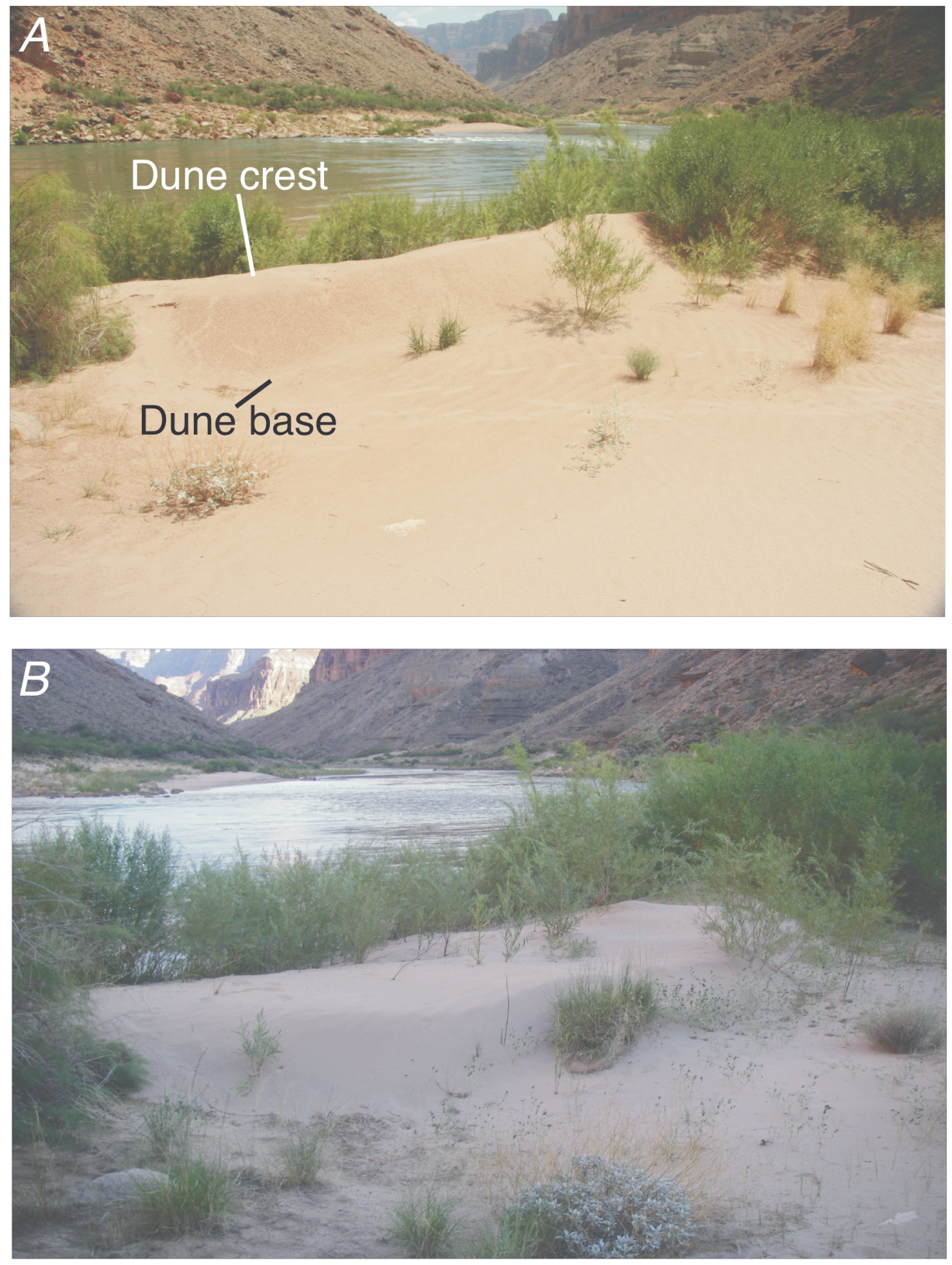

Figure 16. Photograph of an aeolian dune near AZ C:13:0365 that formed on sand deposited by the March 2008 High-Flow Experiment (HFE). The photograph in $A$, taken 
on July 29, 2008, shows a dune crest approximately $1 \mathrm{~m}$ high with an orientation indicating sand moving inland from the river toward larger, well-established aeolian dunes. This dune-migration direction is consistent with the orientation of wind ripples visible on the sediment in the foreground of the photograph and with the dominant wind direction measured at stations AZ C:13:0365 L and AZ C:13:0365 U. The photograph in $B$ shows the same dune on July 26, 2009. The dune crest is still apparent but has flattened to a lower slope than it had in July 2008; vegetation also grew in the intervening year.

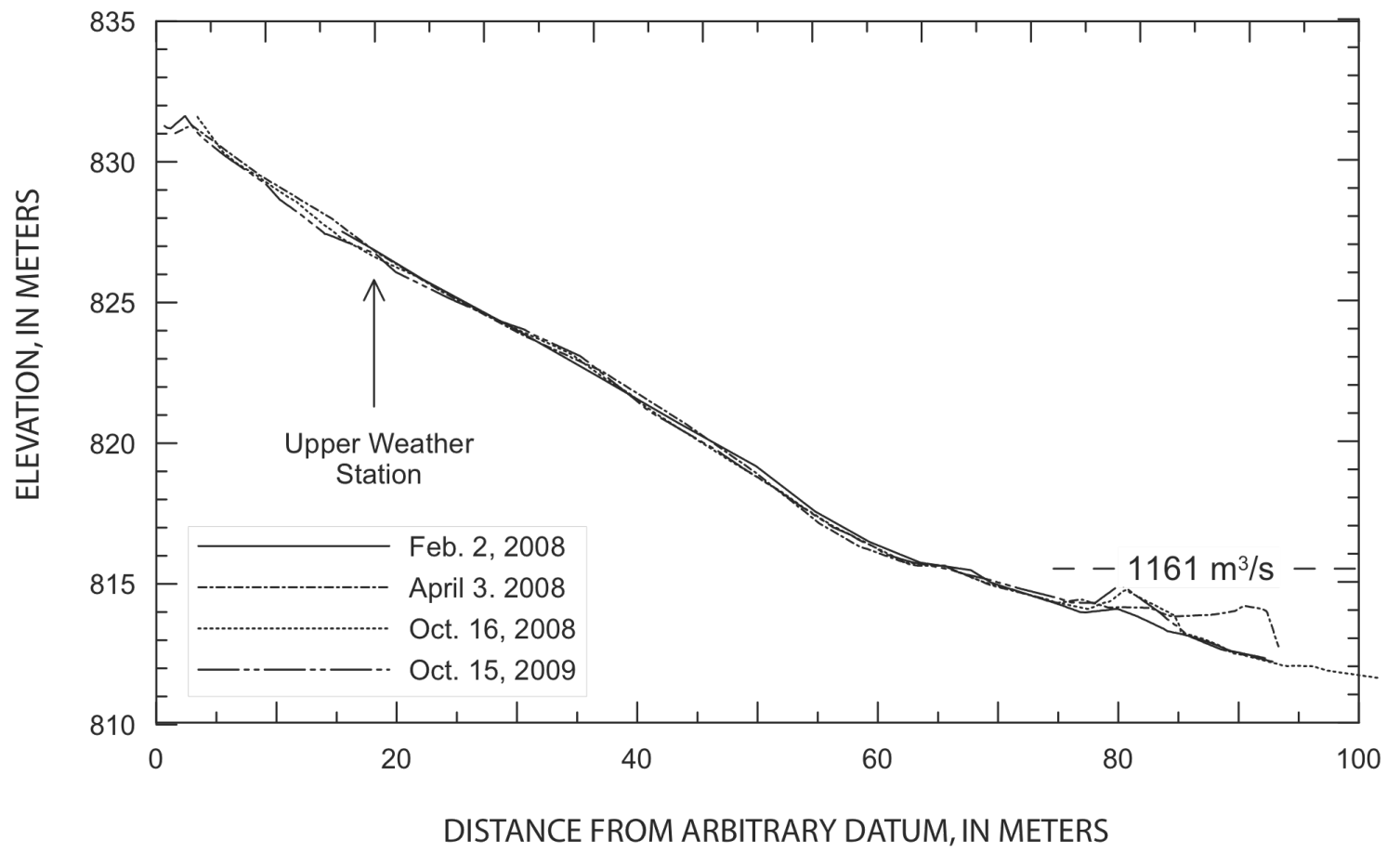

Figure 17. Surveyed profiles of the sandbar near AZ C:13:0365 before and after the 2008 High-Flow Experiment (HFE). The dune crest in figure 16 is evident; it does not appear to have moved landward substantially between October 2008 and October 2009. The elevation of the HFE peak stage is indicated $\left(1,161 \mathrm{~m}^{3} / \mathrm{s}\right)$. Profiles trend approximately northwest, perpendicular to the channel margin. 


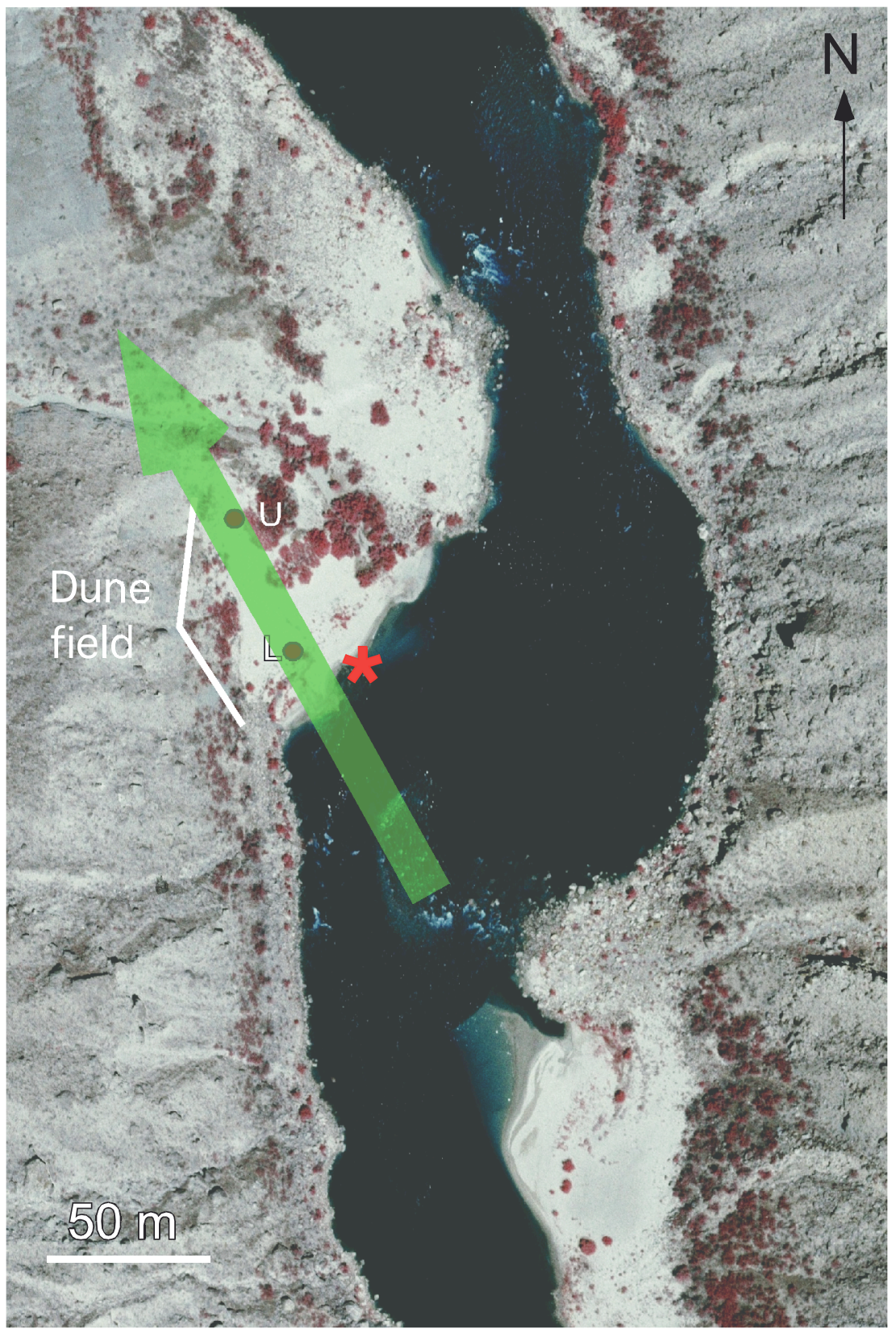

$$
\begin{gathered}
*=\text { Site of HFE- } \\
\text { enlarged sandbar } \\
\odot=\text { Weather station }
\end{gathered}
$$

Figure 18. Aerial photograph of the area around AZ C:13:0365, in Grand Canyon, Ariz., with arrow indicating net direction of potential aeolian sediment transport measured at instrument station AZ C:13:0365 L in 2009. A vector sum of the $Q p$ proxy variable (equation 1), calculated using all wind data collected during dry conditions from AZ C:13:0365 L in 2009, indicates net sediment transport from $151^{\circ}$. 


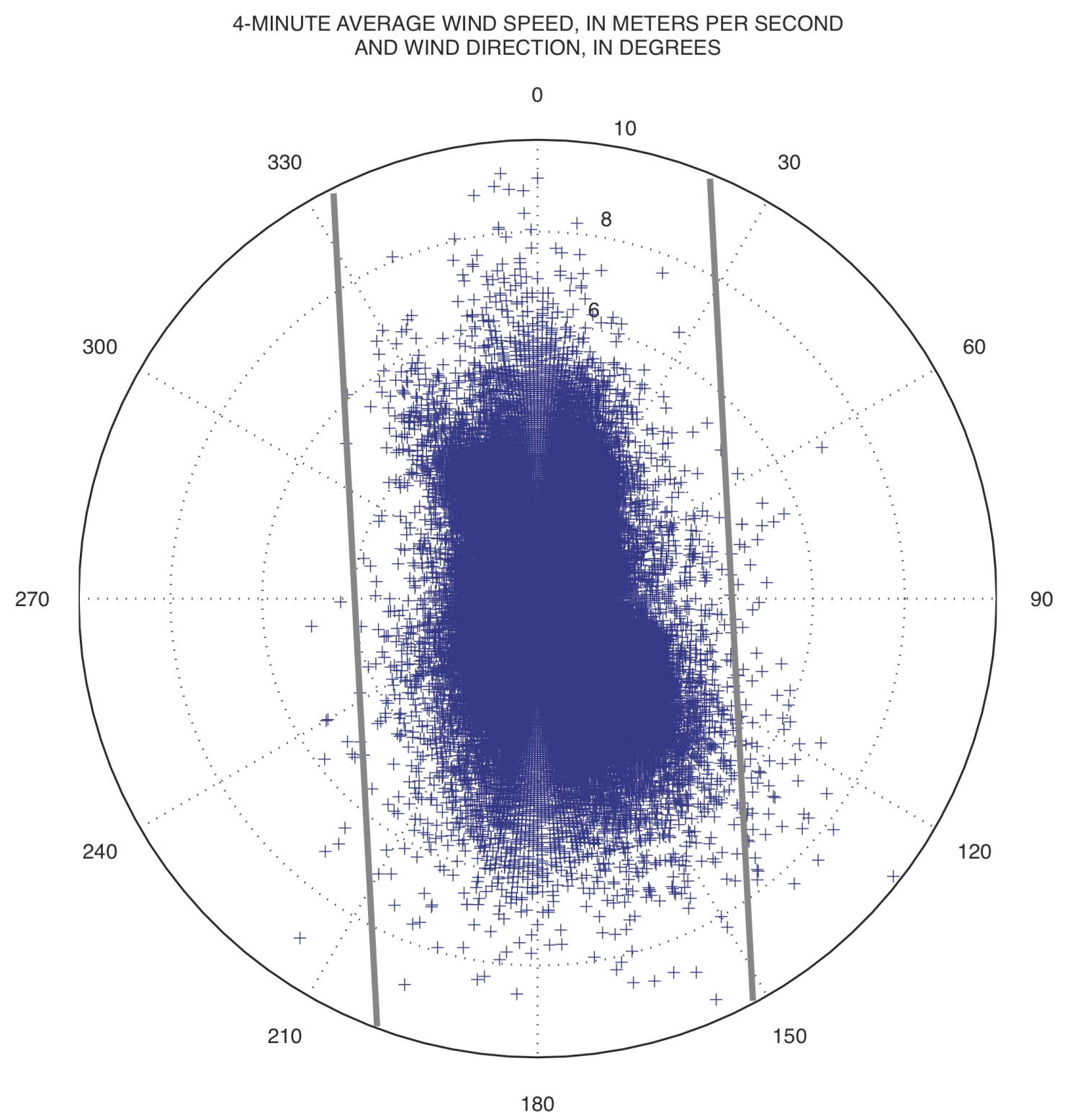

Figure 19. Magnitude and direction of wind velocity measured at the instrument station AZ C:13:0365 L in the Colorado River corridor, Grand Canyon, Ariz., at 4-minute resolution throughout 2009. Magnitude is indicated by the concentric circles, and compass bearing indicates direction from which the wind came. Parallel gray lines show the orientation of the canyon $\left(3^{\circ}\right)$; river flow is toward the south. 
STATION AZ C:13:0365 L

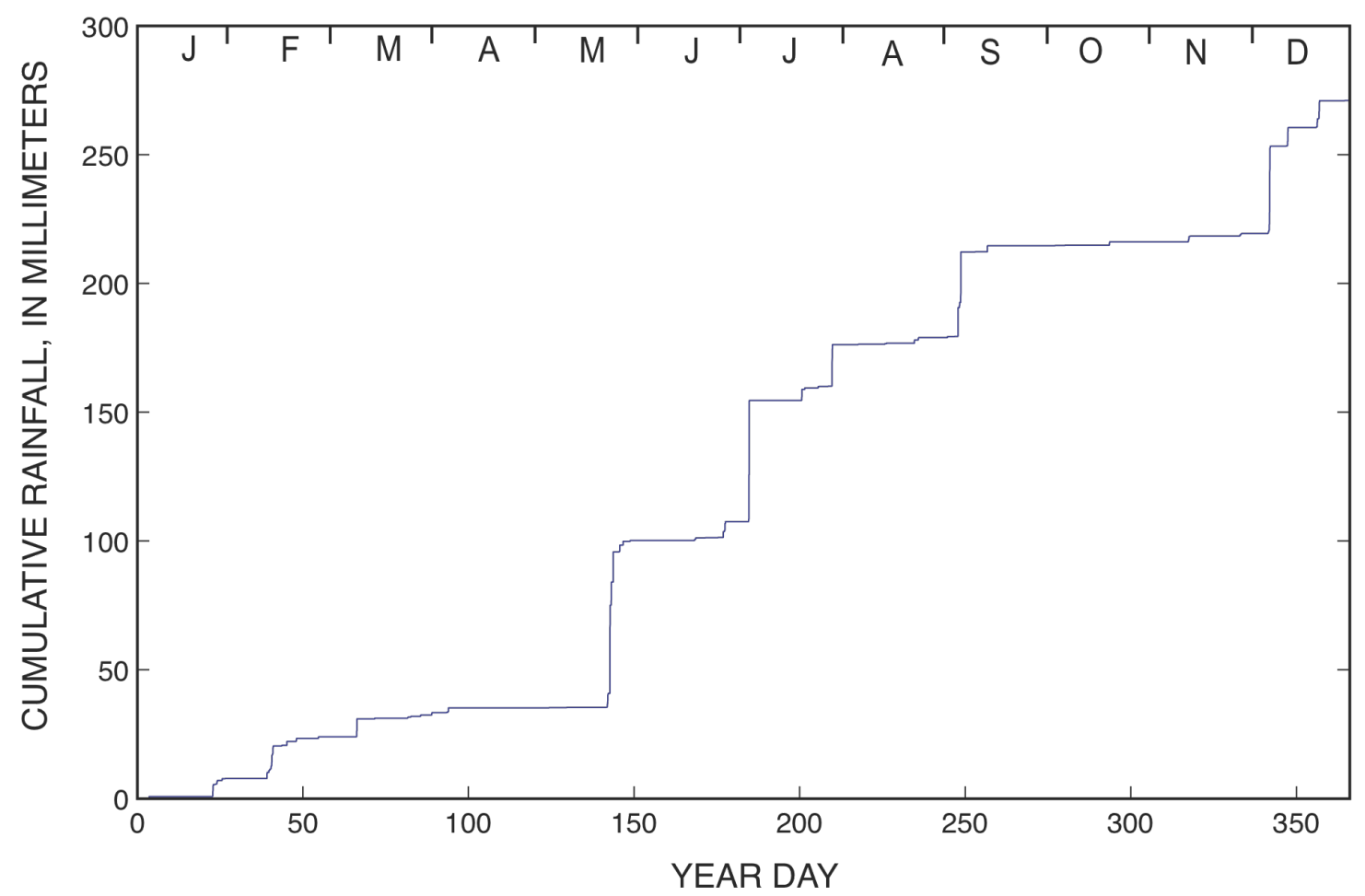

Figure 20. Cumulative 2009 rainfall record measured at AZ C:13:0365 L in the Colorado River corridor, Grand Canyon, Ariz., compiled from data collected at 4-minute resolution. 

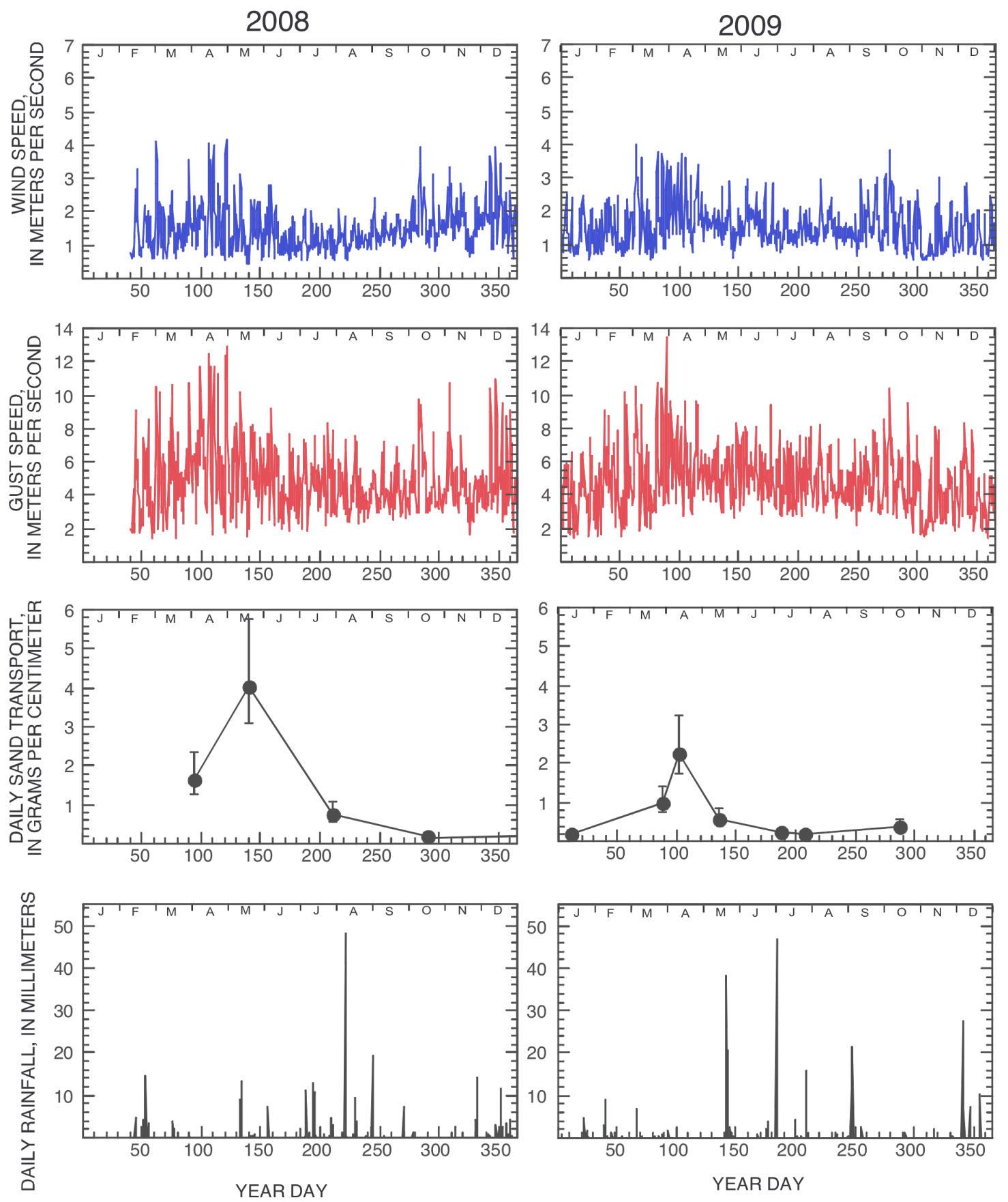

Figure 21. Wind, aeolian sand-transport, and rainfall data collected at the instrument station AZ C:13:0365 L in the Colorado River corridor, Grand Canyon, Ariz., in 2008 and 2009. Daily sand transport is plotted in grams, normalized to a width of $1 \mathrm{~cm}$. To obtain these values, total sand mass collected from four traps during each maintenance visit was divided by number of days since traps had last been emptied. Wind speed (blue plot) is presented as diurnal average values, using daytime $(0600-1800 \mathrm{~h})$ and nighttime $(1800-0600 \mathrm{~h})$ averages of data collected at 4-minute intervals. Gust speed (red plot) is shown as maximum values that occurred during each diurnal interval. Rainfall is plotted as daily (24-hour) totals. 

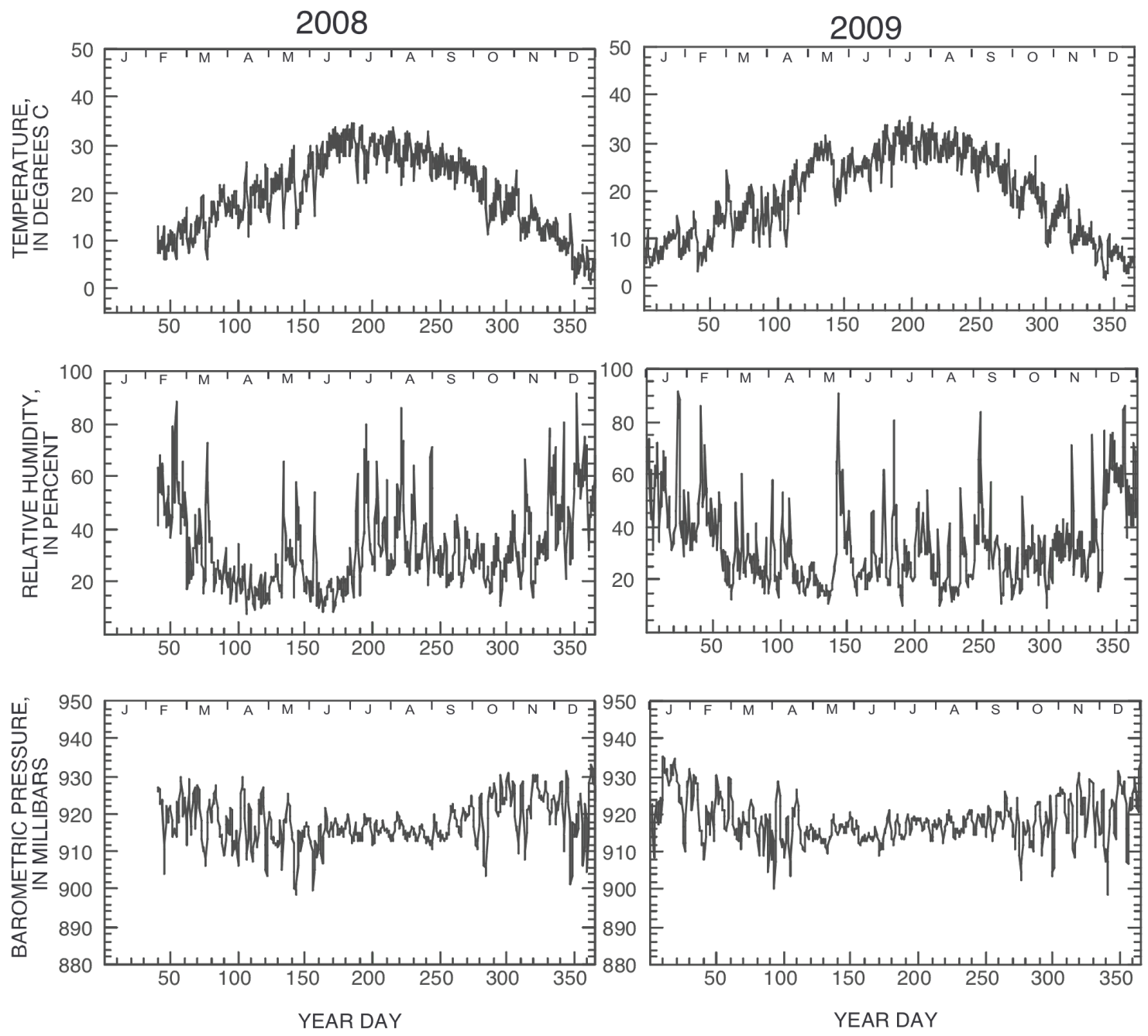

Figure 22. Temperature, humidity, and barometric pressure data collected at the instrument station AZ C:13:0365 L in the Colorado River corridor, Grand Canyon, Ariz., in 2008 and 2009. All parameters are plotted as diurnal averages (defined using 0600-1800 and 1800-0600 h). 


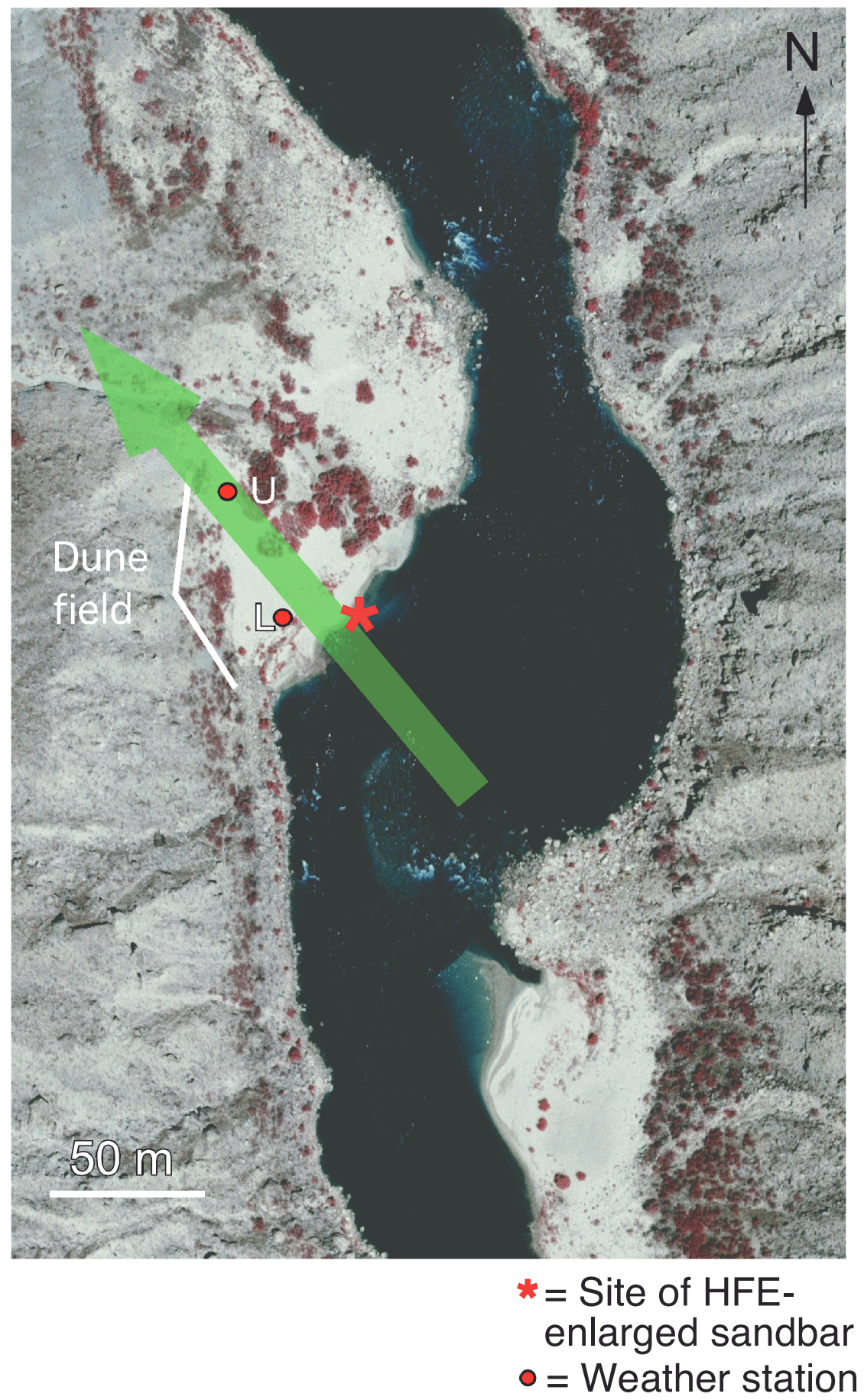

Figure 23. Aerial photograph of the area around AZ C:13:0365, in Grand Canyon, Ariz., with arrow indicating net direction of potential aeolian sediment transport measured at instrument station AZ C:13:0365 $\mathrm{U}$ in 2009. A vector sum of the $Q p$ proxy variable (equation 1), calculated using all wind data collected during dry conditions from AZ $\mathrm{C}: 13: 0365 \mathrm{U}$ in 2009 , indicates net sediment transport from $140^{\circ}$. 


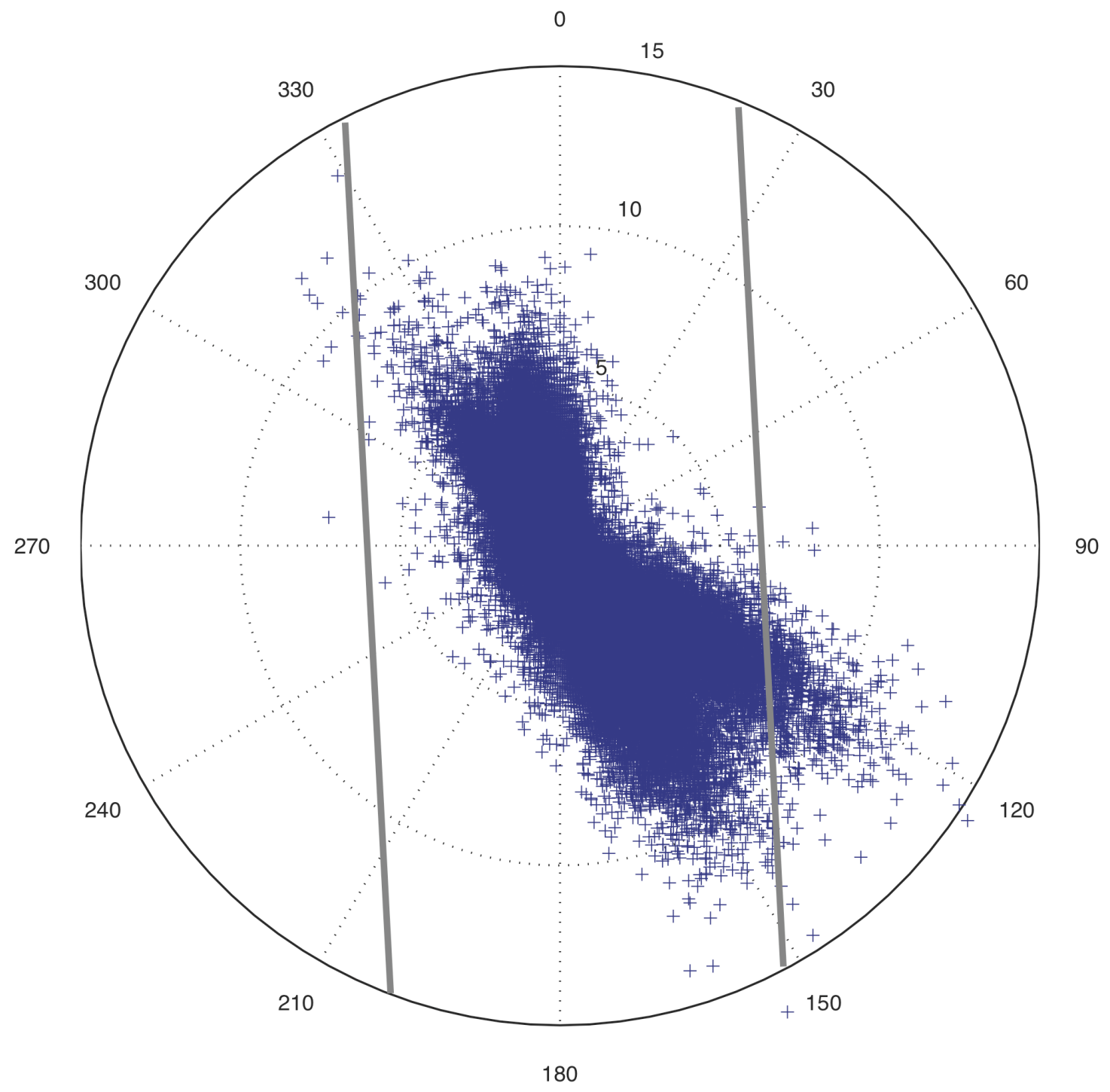

Figure 24. Magnitude and direction of wind velocity measured at the instrument station AZ C:13:0365 U in the Colorado River corridor, Grand Canyon, Ariz., at 4-minute resolution throughout 2009. Magnitude is indicated by the concentric circles, and compass bearing indicates direction from which the wind came. Parallel gray lines show the orientation of the canyon $\left(3^{\circ}\right)$; river flow is toward the south. 
STATION AZ C:13:0365 U

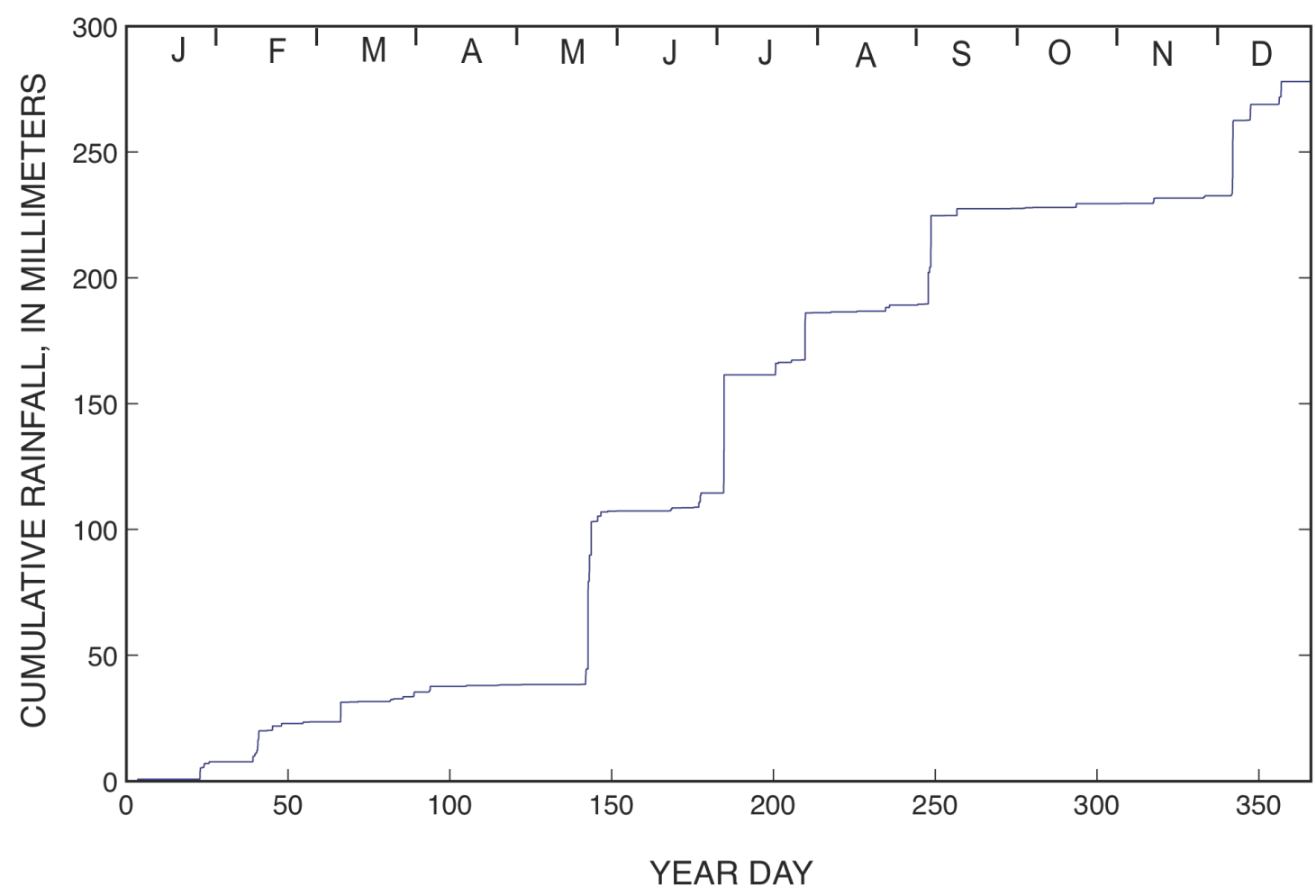

Figure 25. Cumulative 2009 rainfall record measured at AZ C:13:0365 U in the Colorado River corridor, Grand Canyon, Ariz., compiled from data collected at 4-minute resolution. 
2008
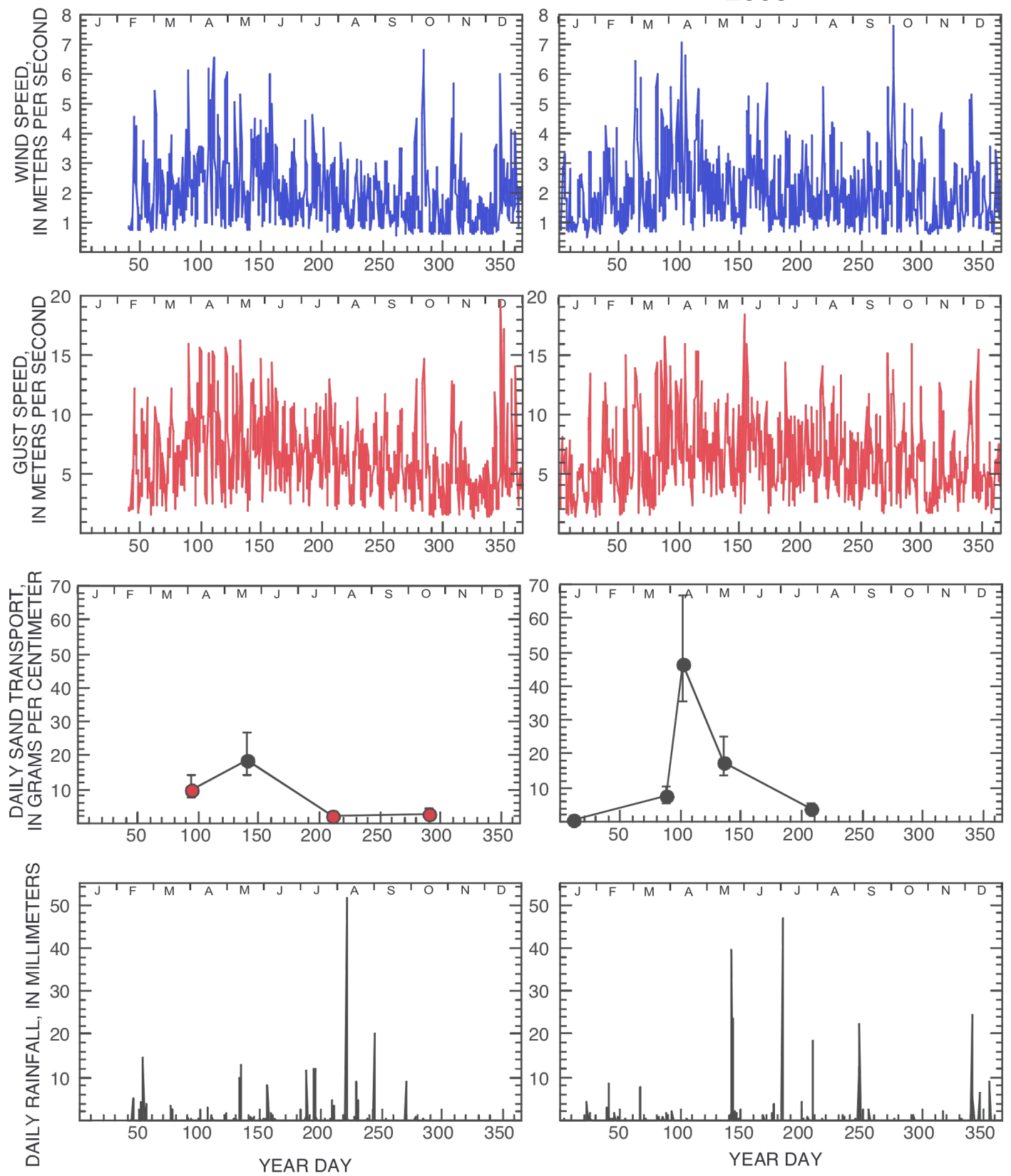

2009
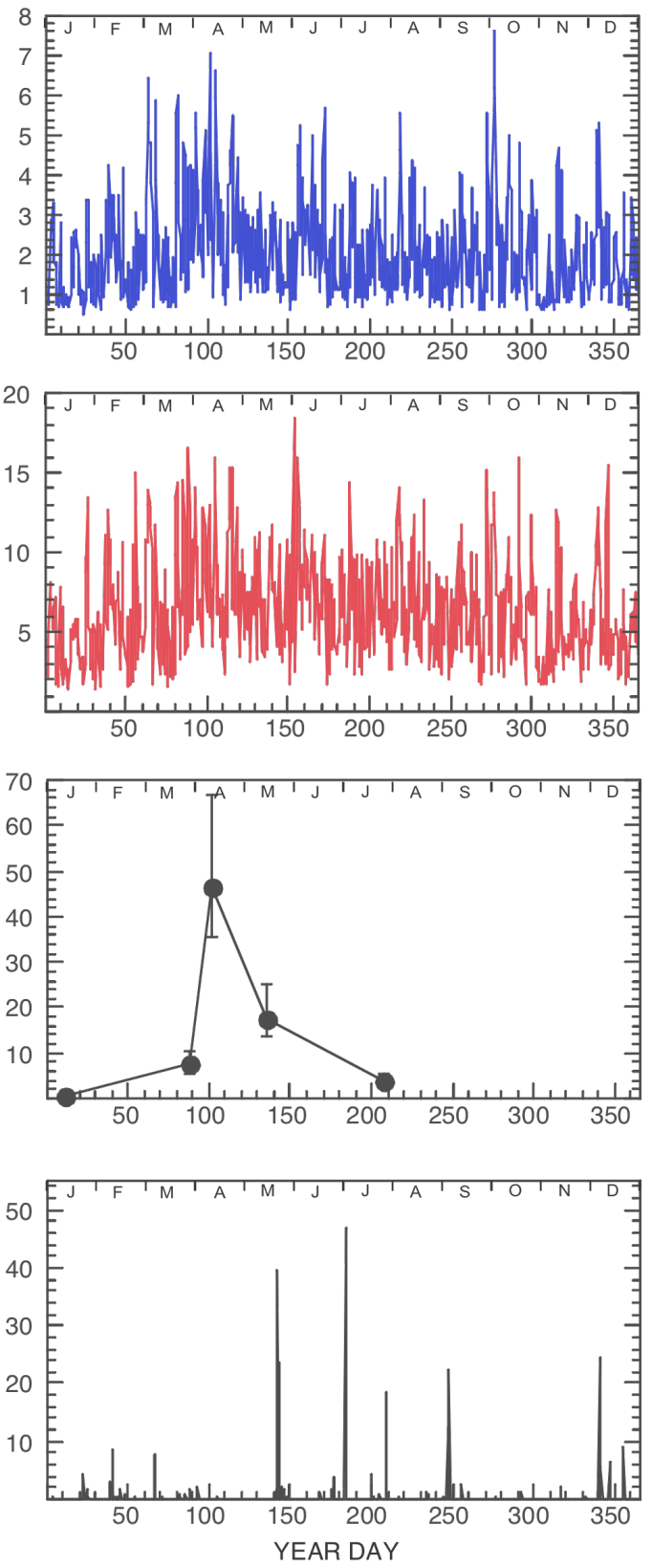

Figure 26. Wind, aeolian sand-transport, and rainfall data collected at the instrument station AZ C:13:0365 U in the Colorado River corridor, Grand Canyon, Ariz., in 2008 and 2009. Daily sand transport is plotted in grams, normalized to a width of $1 \mathrm{~cm}$. To obtain these values, total sand mass collected from four traps during each maintenance visit was divided by number of days since traps had last been emptied. Red circles on the sand-transport plot indicate minimum estimates only; these were made from data when the sand traps were found to have been blown over by the wind. Wind speed (blue plot) is presented as diurnal average values, using daytime (0600-1800 h) and nighttime (1800$0600 \mathrm{~h}$ ) averages of data collected at 4-minute intervals. Gust speed (red plot) is shown as maximum values that occurred during each diurnal interval. Rainfall is plotted as daily (24-hour) totals. 

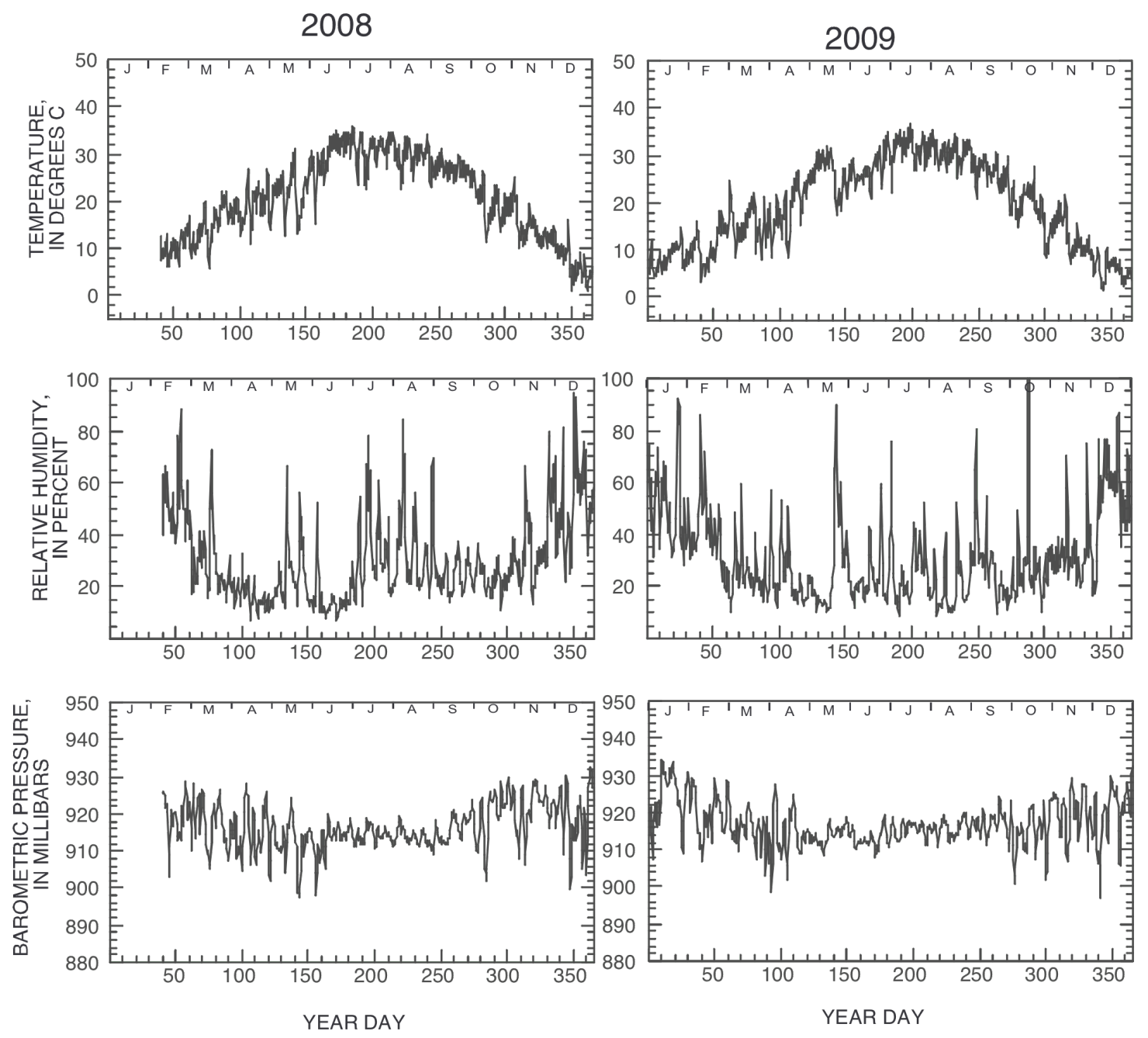

Figure 27. Temperature, humidity, and barometric pressure data collected at the instrument station AZ C:13:0365 L in the Colorado River corridor, Grand Canyon, Ariz., in 2008 and 2009. All parameters are plotted as diurnal averages (defined using 0600-1800 and 1800-0600 h). 


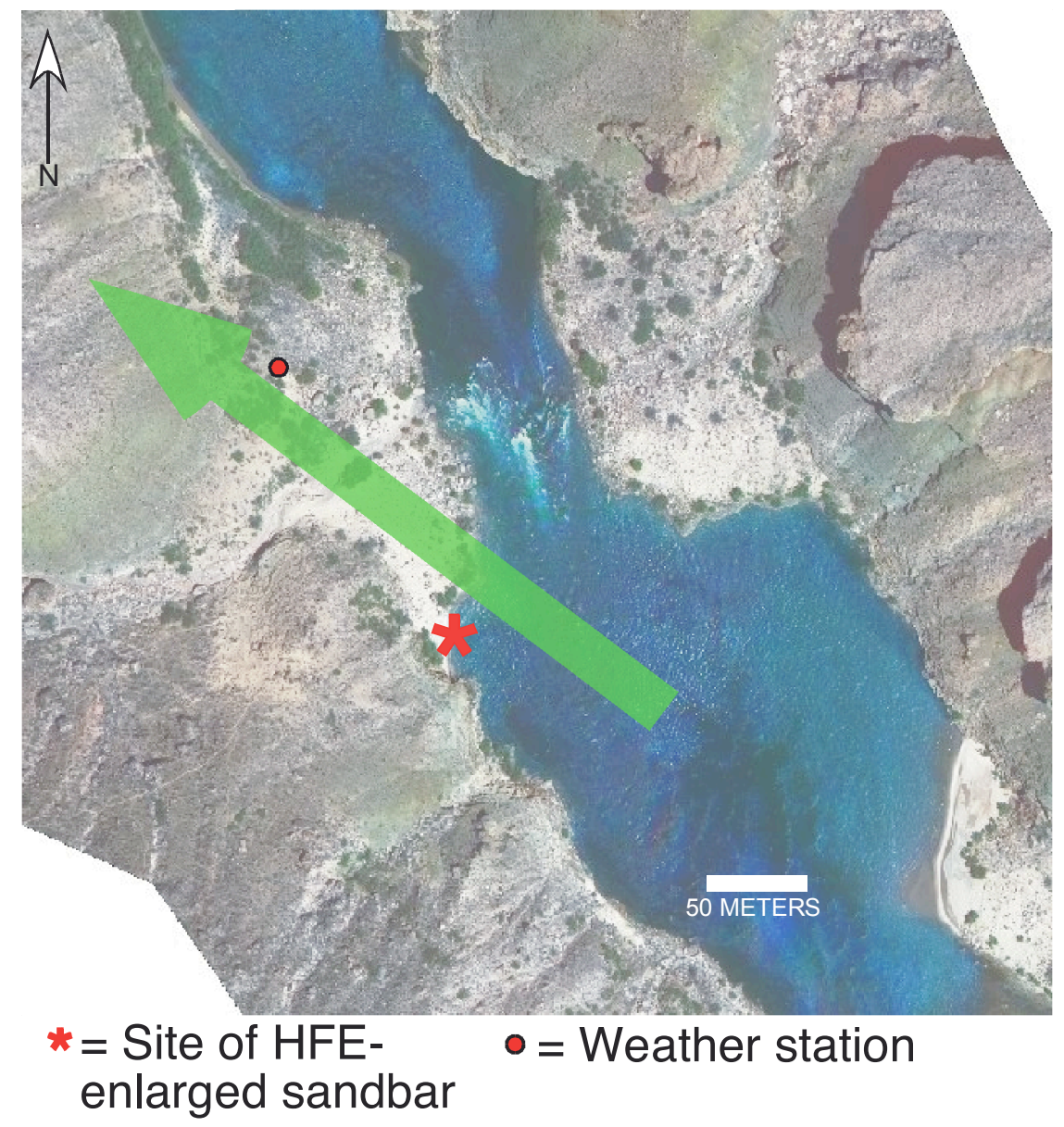

Figure 28. Aerial photograph of the area around AZ C:13:0006, in Grand Canyon, Ariz., with arrow indicating net direction of potential aeolian sediment transport measured in 2009. A vector sum of the $Q p$ proxy variable (equation 1), calculated using all wind data collected during dry conditions from AZ C:13:0006 in 2009, indicates net sediment transport from $127^{\circ}$. 


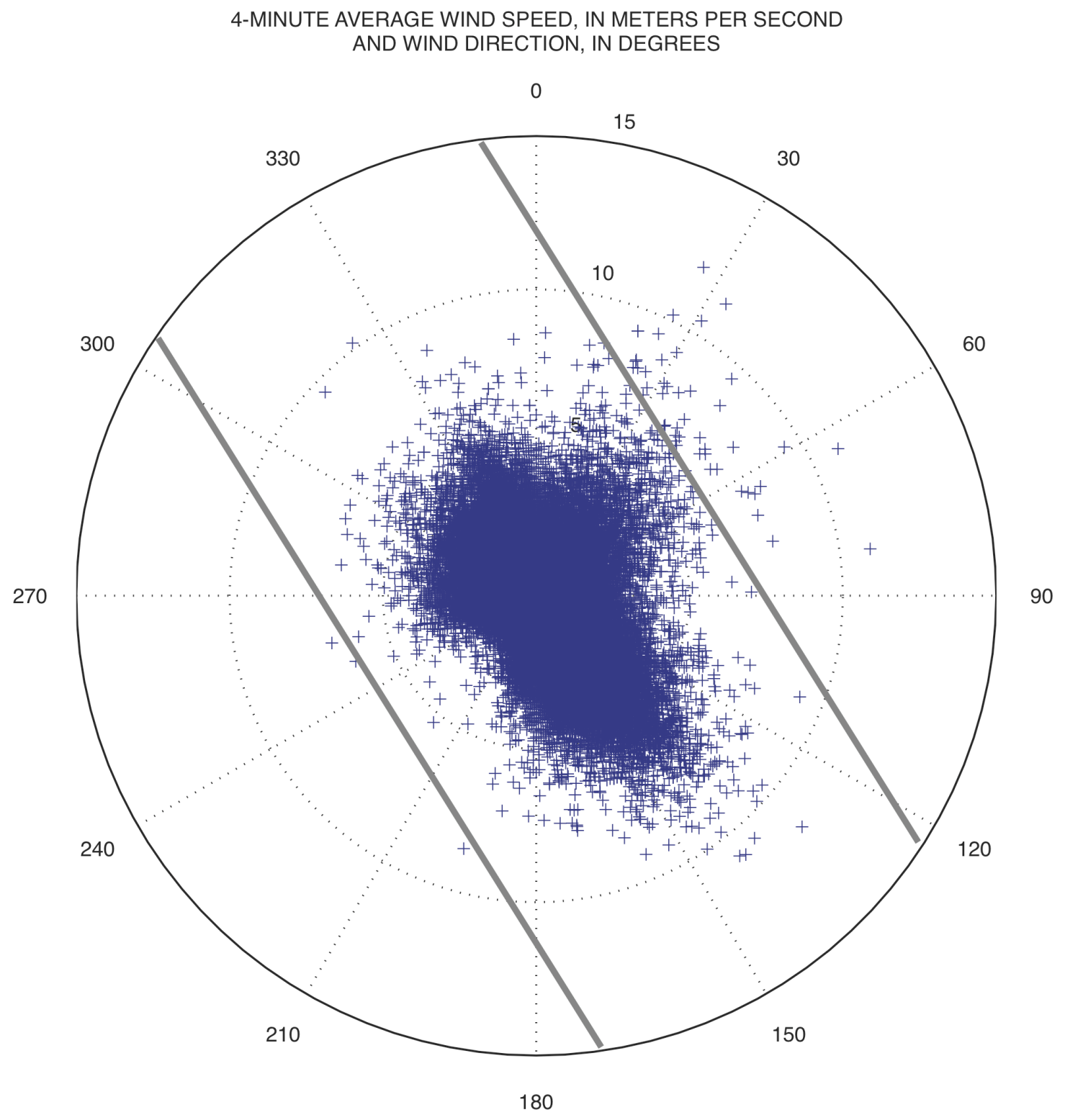

Figure 29. Magnitude and direction of wind velocity measured at the instrument station AZ C:13:0006 in the Colorado River corridor, Grand Canyon, Ariz., at 4-minute resolution in 2009. Magnitude is indicated by the concentric circles, and compass bearing indicates direction from which the wind came. Parallel gray lines show the orientation of the canyon $\left(328^{\circ}\right)$; river flow is toward the south. 


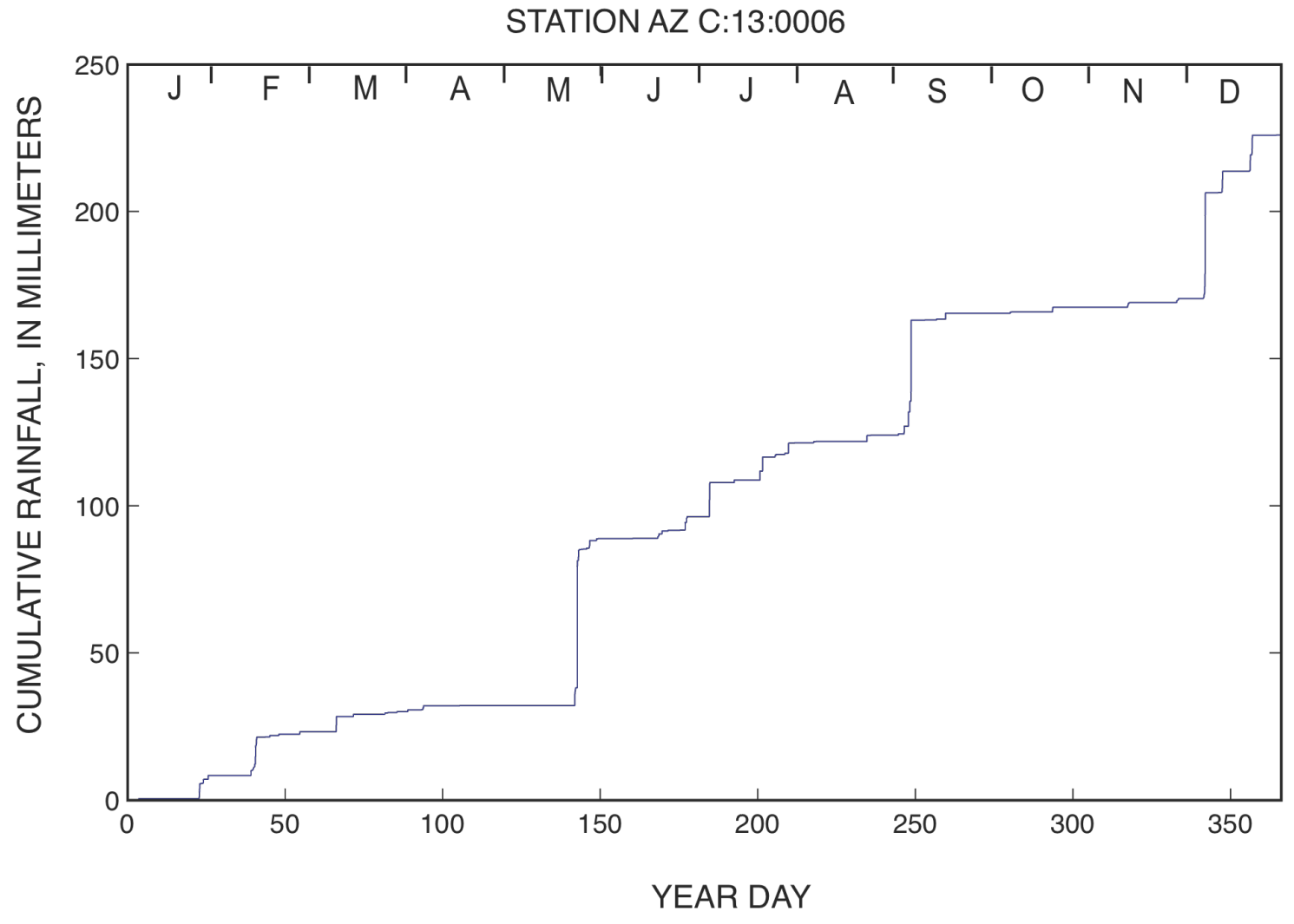

Figure 30. Cumulative 2009 rainfall record measured at AZ C:13:0006 in the Colorado River corridor, Grand Canyon, Ariz., compiled from data collected at 4-minute resolution. 
2008
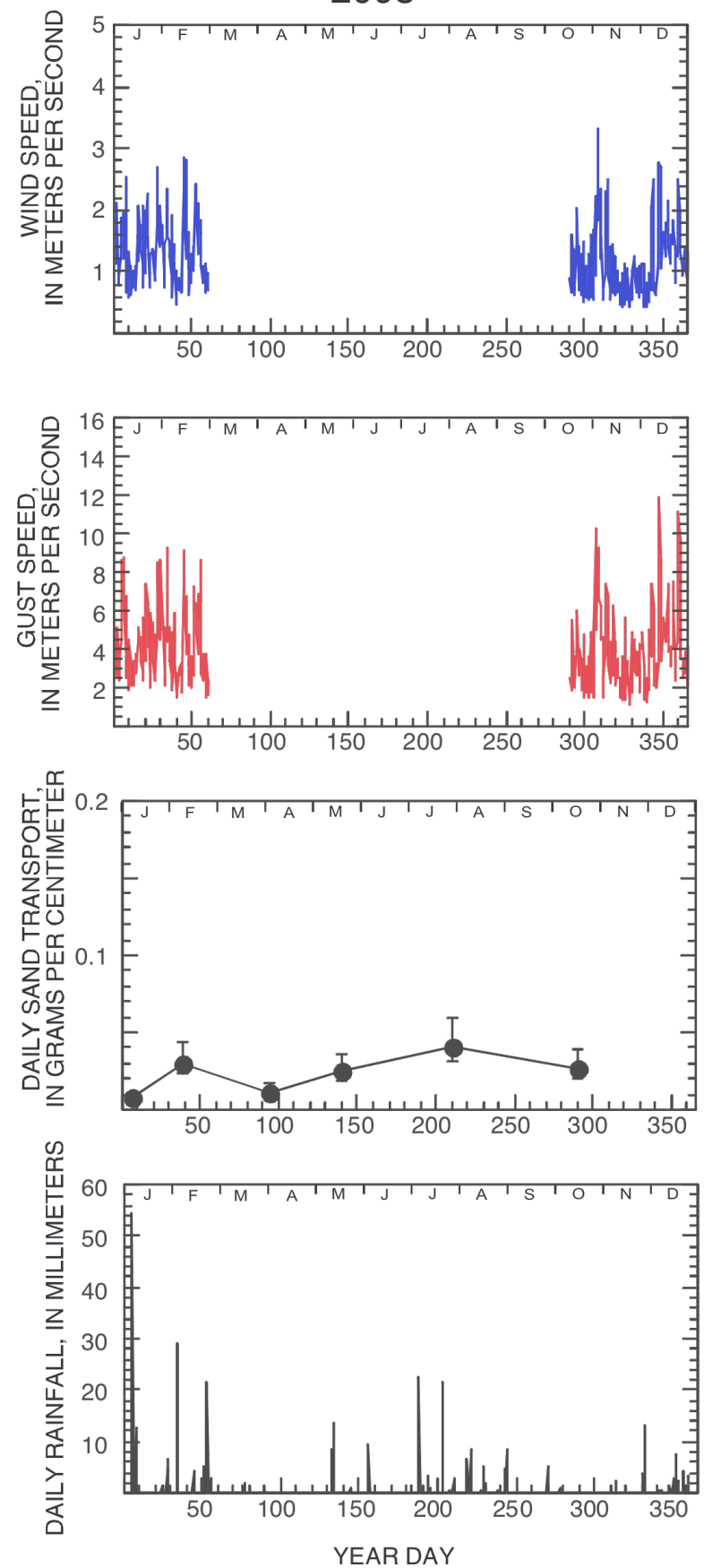

2009
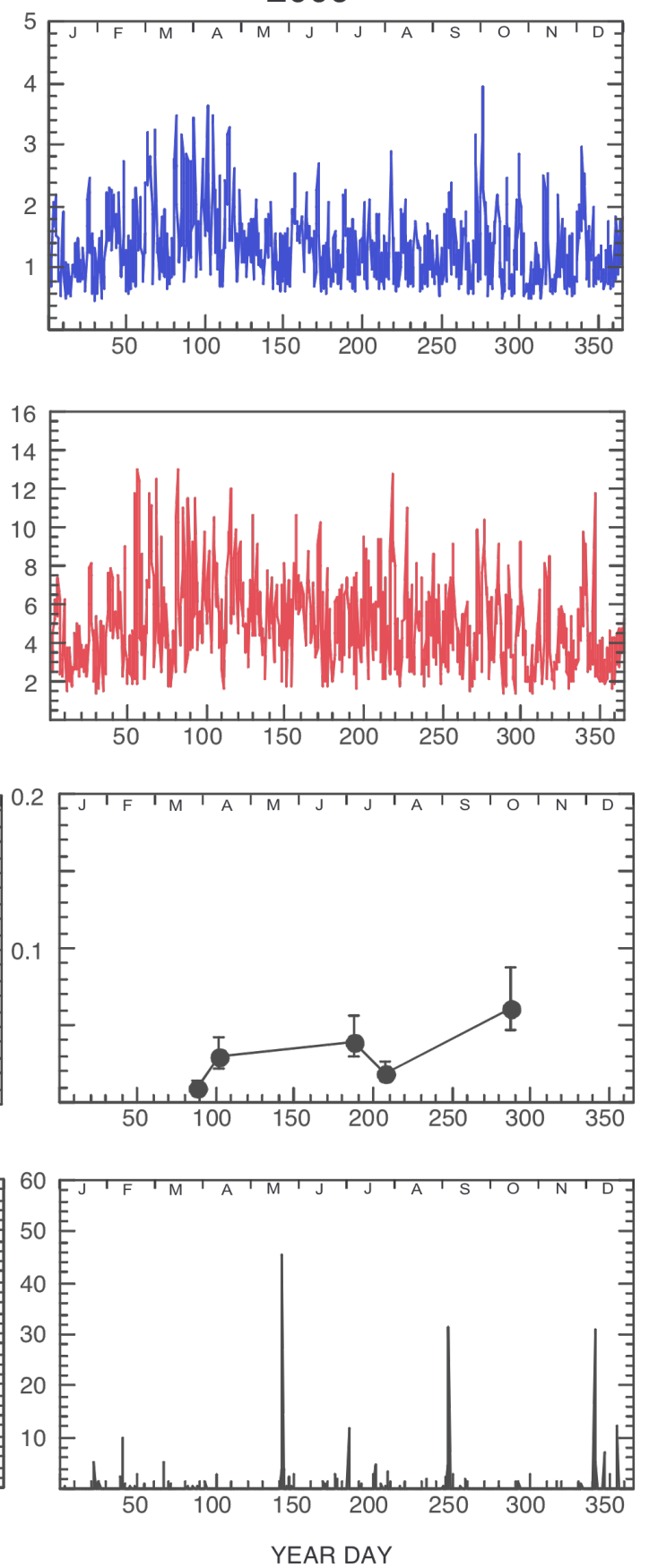

Figure 31. Wind, aeolian sand-transport, and rainfall data collected at the instrument station AZ C:13:0006 in the Colorado River corridor, Grand Canyon, Ariz., in 2008 and 2009. Daily sand transport is plotted in grams, normalized to a width of $1 \mathrm{~cm}$. To obtain these values, total sand mass collected from four traps during each maintenance visit was divided by number of days since traps had last been emptied. Wind speed (blue plot) is presented as diurnal average values, using daytime (0600-1800 h) and nighttime (1800$0600 \mathrm{~h}$ ) averages of data collected at 4-minute intervals. Gust speed (red plot) is shown as maximum values that occurred during each diurnal interval. Rainfall is plotted as daily (24-hour) totals. 

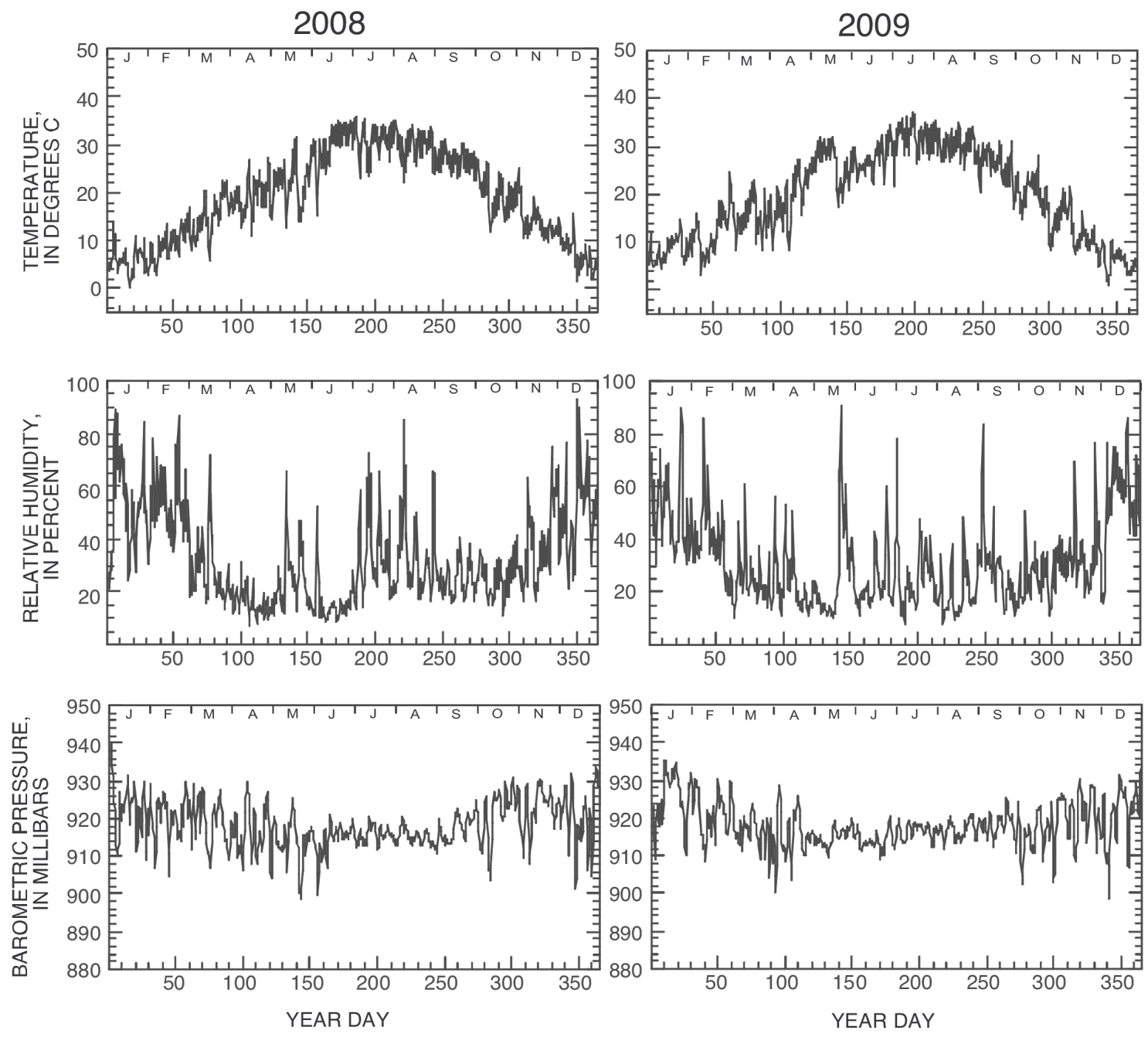

Figure 32. Temperature, humidity, and barometric pressure data collected at the instrument station AZ C:13:0006 in the Colorado River corridor, Grand Canyon, Ariz., in 2008 and 2009. All parameters are plotted as diurnal averages (defined using 0600-1800 and $1800-0600 \mathrm{~h}$ ). 

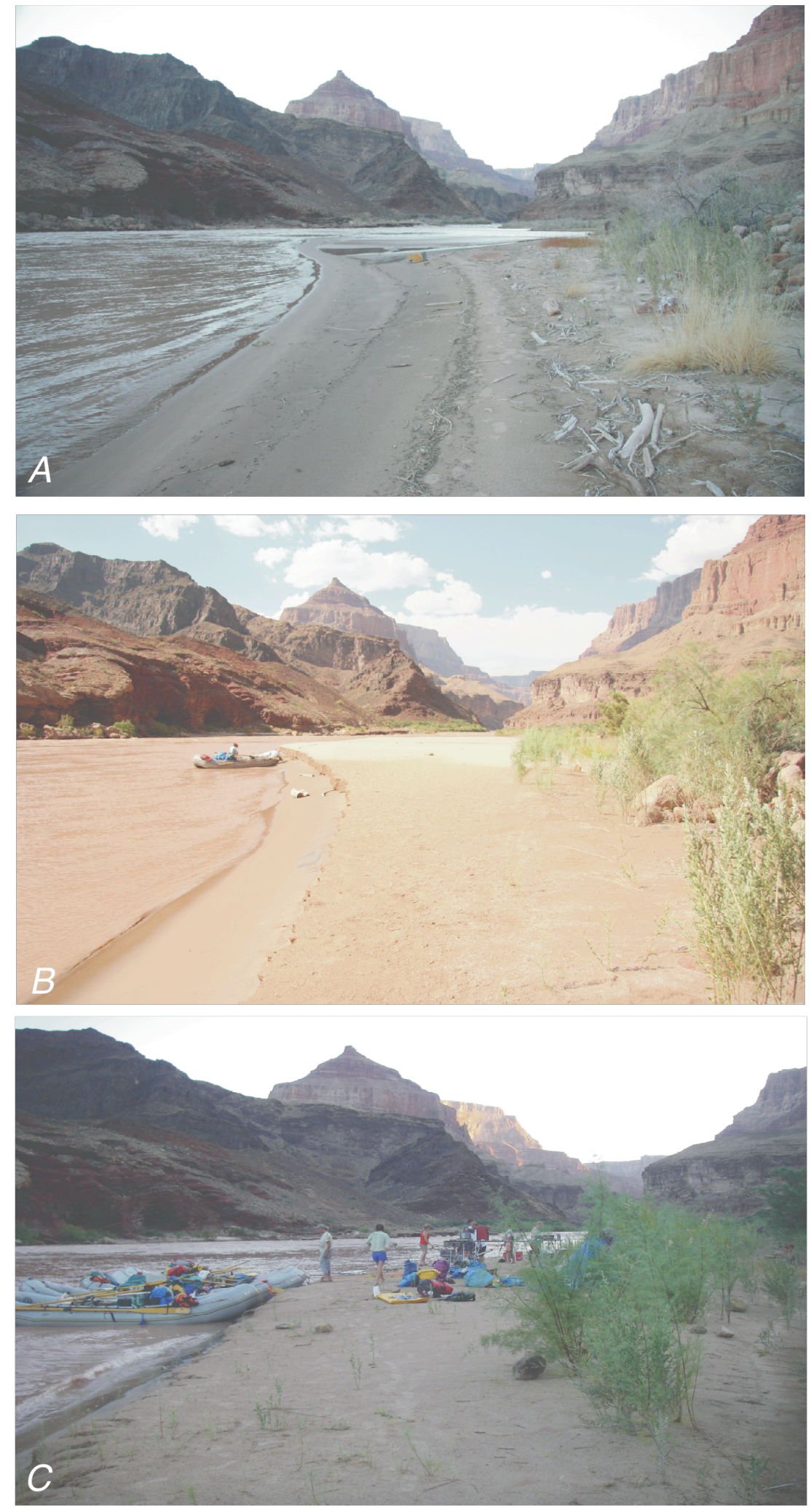

Figure 33. Photographs of the sandbar near AZ C:13:0336 before and after the 2008 High-Flow Experiment (HFE). A, Photograph taken from the edge of the river facing 
upstream and looking at the sandbar on February 10, 2008, before the HFE. $B$, Photograph taken from the same location on July 29, 2008, showing a wider, thicker (higher-elevation) sandbar than in the pre-flood condition. $C$, Photograph taken from the same location on July 27, 2009, showing that the sandbar was still present but had narrowed from its July 2008 condition and that young tamarisk plants had grown on the landward (river left, right side of photograph) portion of the sandbar.

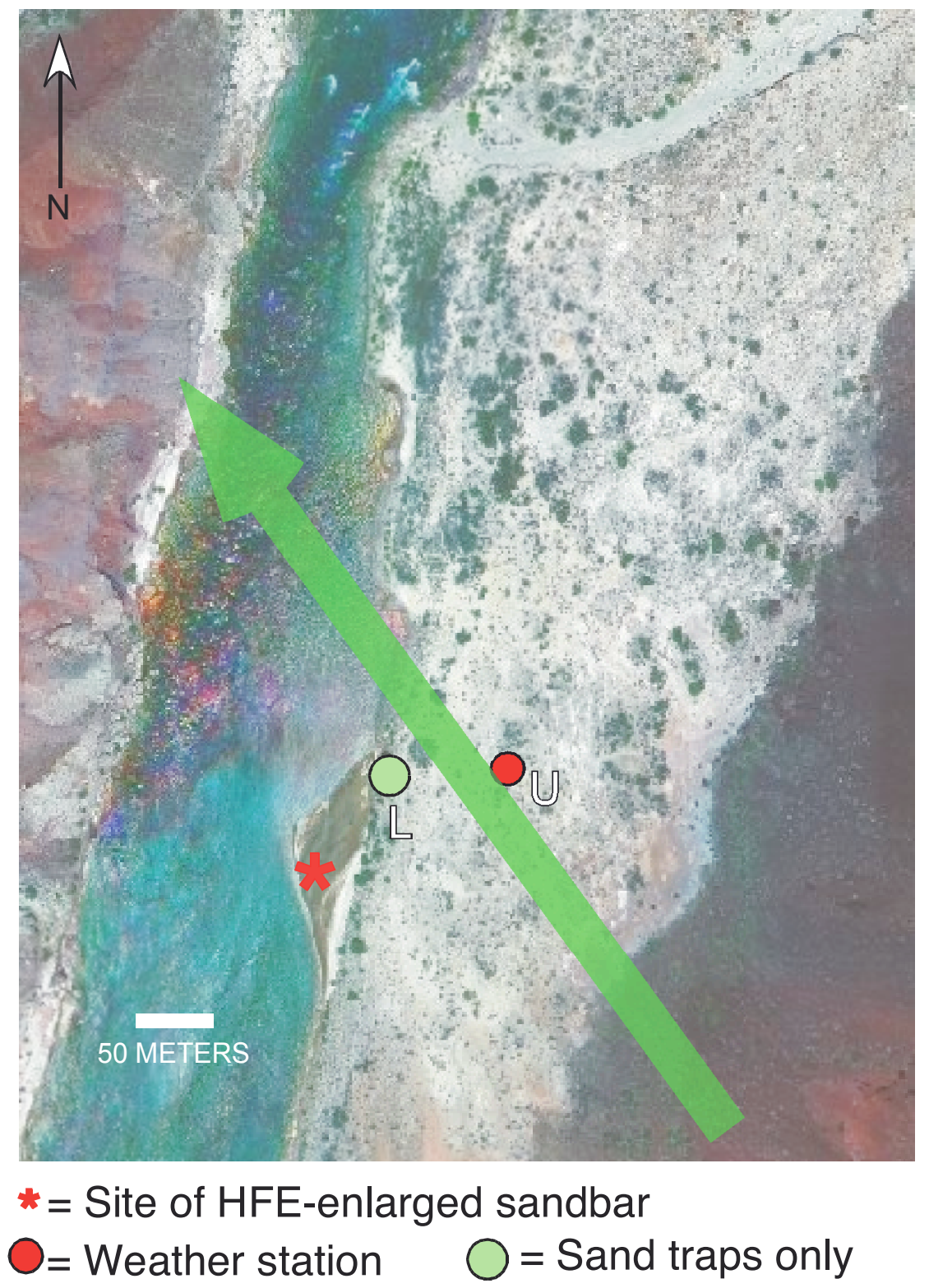

Figure 34. Aerial photograph of the area around AZ C:13:0336, in Grand Canyon, Ariz., with arrow indicating net direction of potential aeolian sediment transport measured at AZ C:13:0336 $\mathrm{U}$ in 2009. A vector sum of the $Q p$ proxy variable (equation 1), calculated using all wind data collected during dry conditions from AZ C:13:0336 U in 2009, indicates net sediment transport from $144^{\circ}$. 


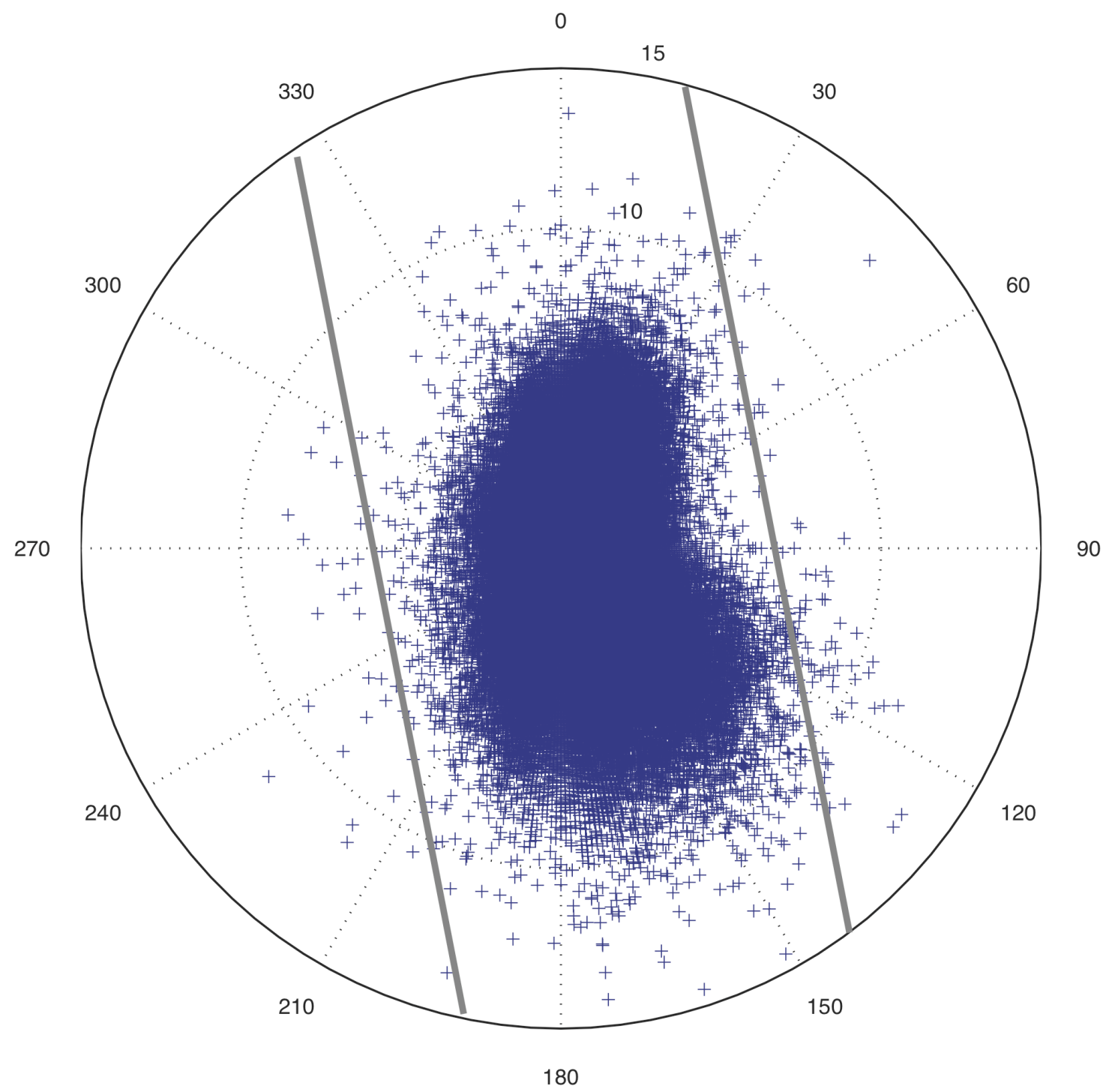

Figure 35. Magnitude and direction of wind velocity measured at the instrument station AZ C:13:0336 U in the Colorado River corridor, Grand Canyon, Ariz., at 4-minute resolution throughout 2009. Magnitude is indicated by the concentric circles, and compass bearing indicates direction from which the wind came. Parallel gray lines show the orientation of the canyon $\left(11^{\circ}\right)$; river flow is toward the south. 


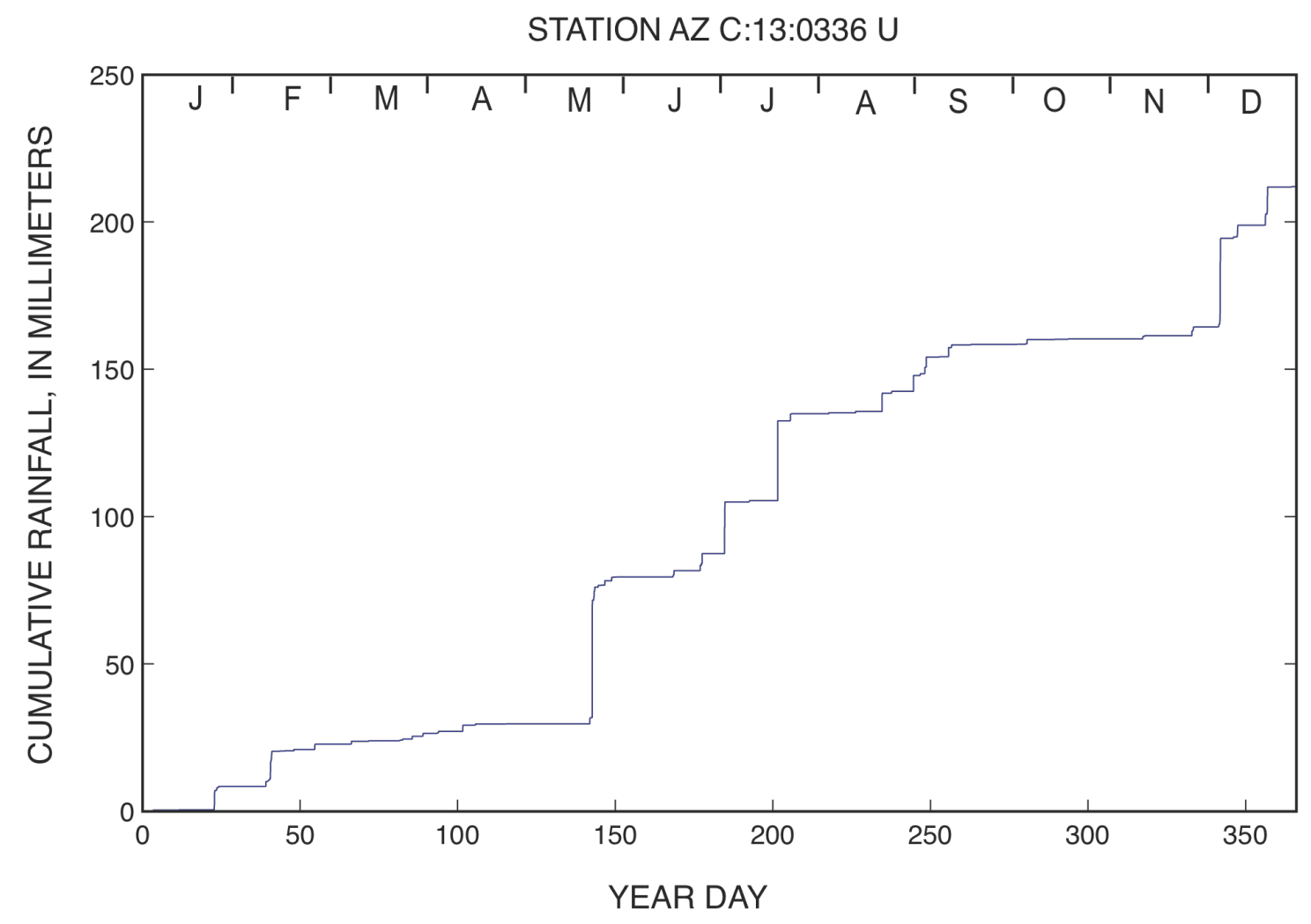

Figure 36. Cumulative 2009 rainfall record measured at AZ C:13:0336 U, compiled from data collected at 4-minute resolution. 

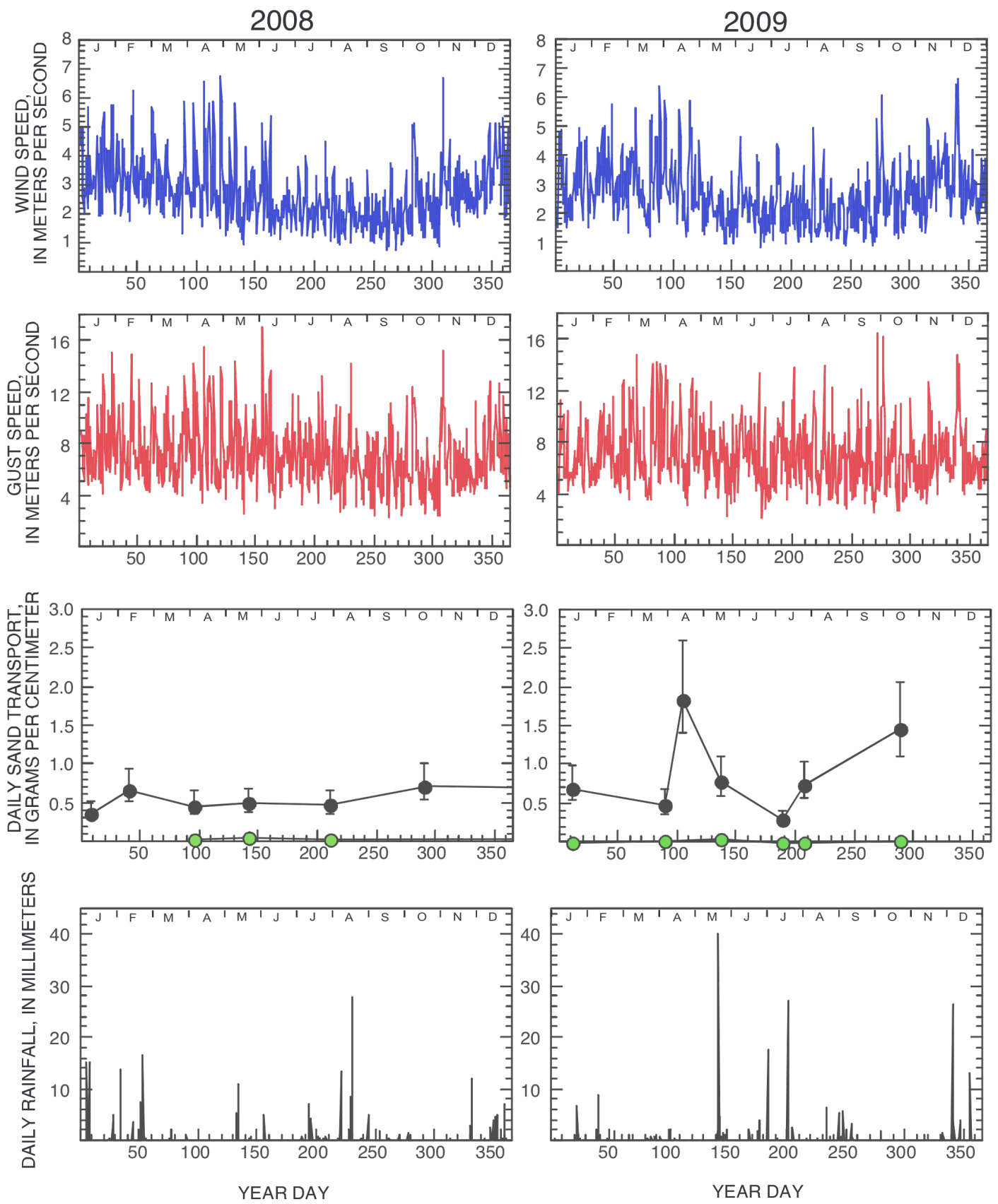

Figure 37. Wind, aeolian sand-transport, and rainfall data collected at the instrument station AZ C:13:0336 U in the Colorado River corridor, Grand Canyon, Ariz., in 2008 and 2009, and sand-transport data collected at AZ C:13:0336 L (green circles). Daily sand transport is plotted in grams, normalized to a width of $1 \mathrm{~cm}$. To obtain these values, total sand mass collected from four traps during each maintenance visit was divided by number of days since traps had last been emptied. Wind speed (blue plot) is presented as diurnal average values, using daytime $(0600-1800 \mathrm{~h})$ and nighttime (1800-0600 h) averages of data collected at 4-minute intervals. Gust speed (red plot) is shown as maximum values that occurred during each diurnal interval. Rainfall is plotted as daily (24-hour) totals. 

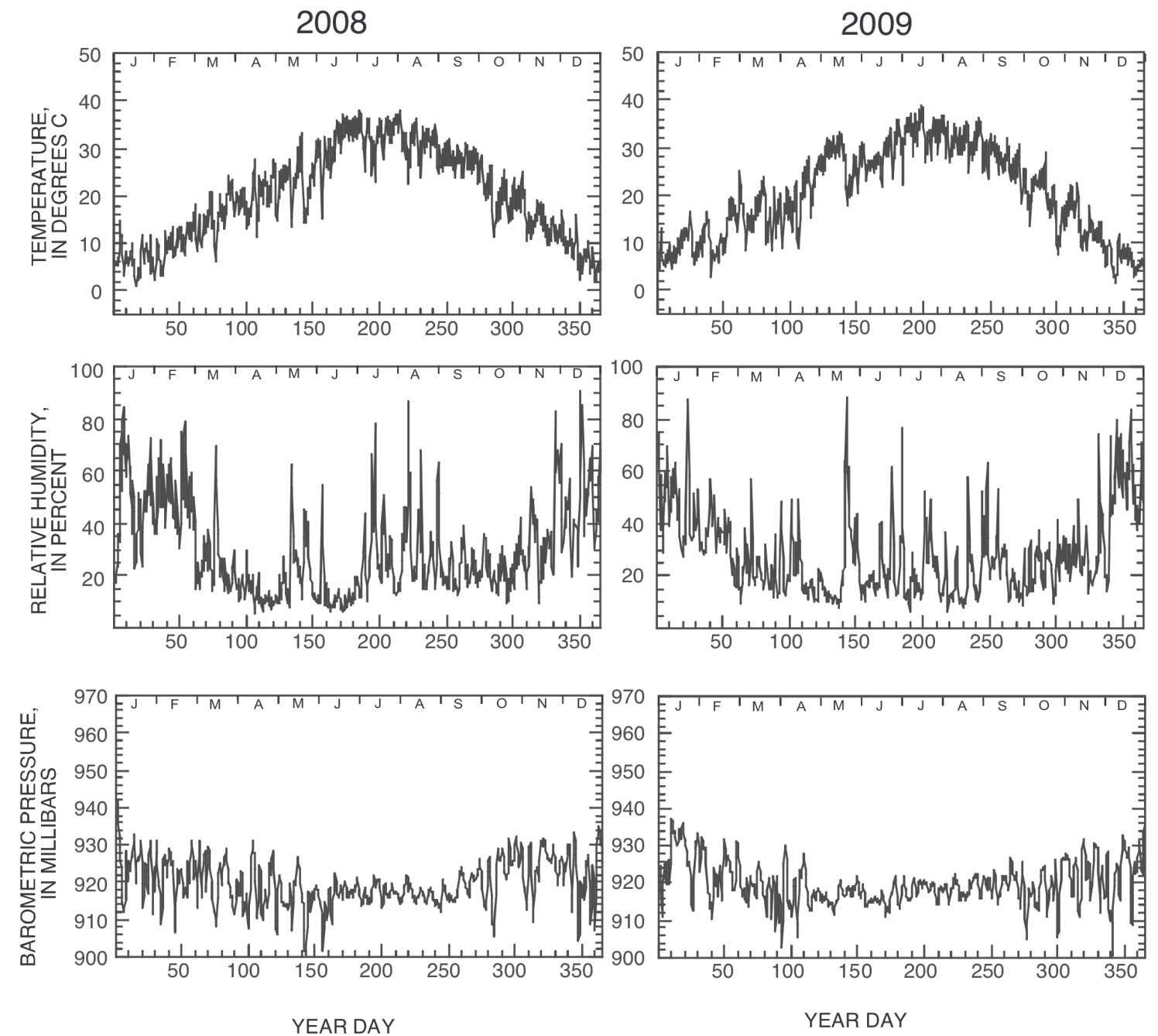

Figure 38. Temperature, humidity, and barometric pressure data collected at the instrument station AZ C:13:0336 U in the Colorado River corridor, Grand Canyon, Ariz., in 2008 and 2009. All parameters are plotted as diurnal averages (defined using 0600-1800 and 1800-0600 h). 

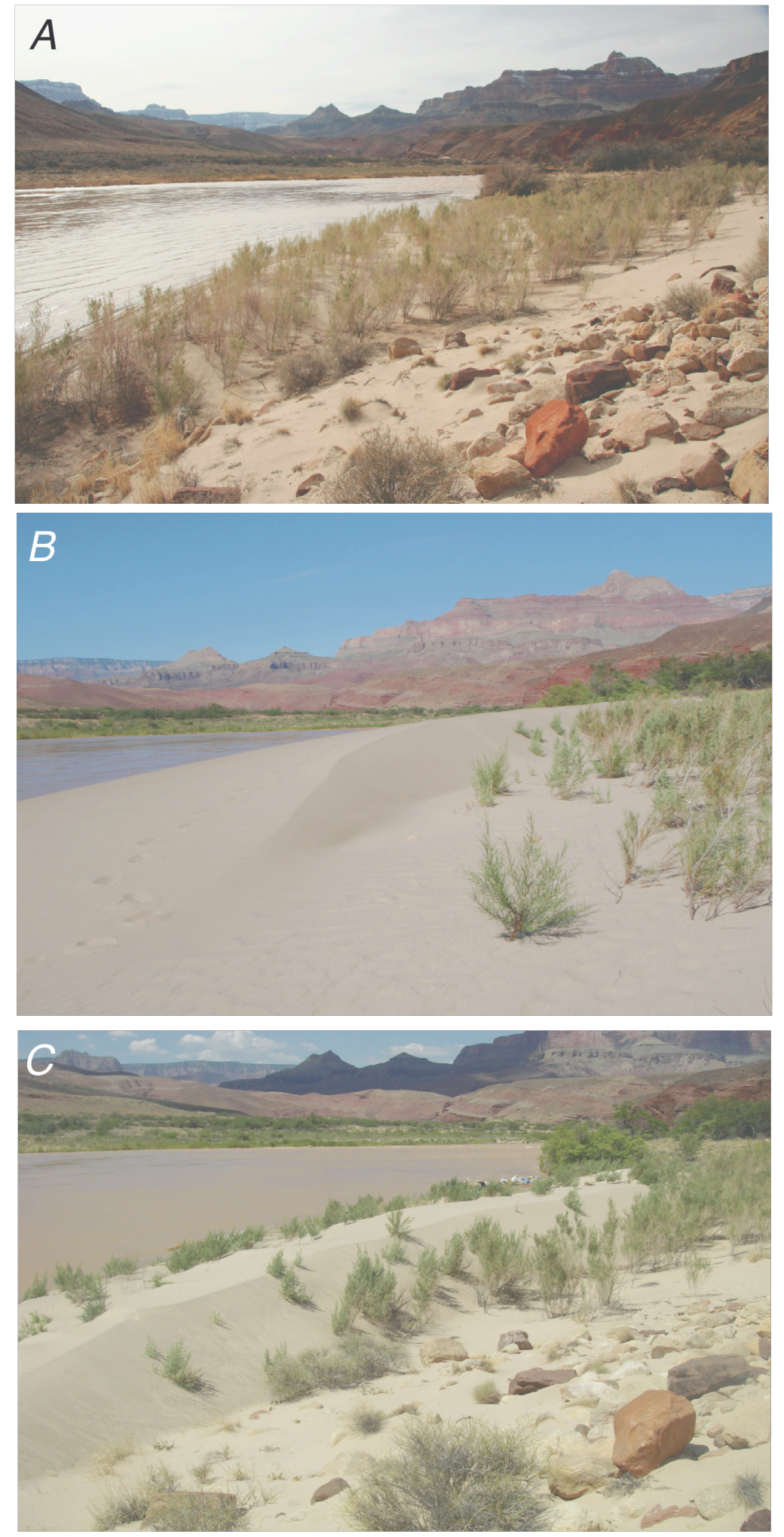

Figure 39. Photographs of the sandbar near AZ C:13:0321 before and after the 2008 High-Flow Experiment (HFE). A, Photograph taken near the edge of the river facing downstream and looking at the sandbar, on February 10, 2008, before the HFE. $B$, 
Photograph taken from approximately the same location on July 29, 2008, showing the crest of a new aeolian dune that formed from wind reworking of HFE sand. The slipface orientation of the dune indicates the dune is migrating, and moving sand, inland toward the field of larger aeolian dunes. $C$, Photograph taken from approximately the same location on July 28,2009 , showing the same dune crest that had moved inland by $10 \mathrm{~m}$ in the preceding year.

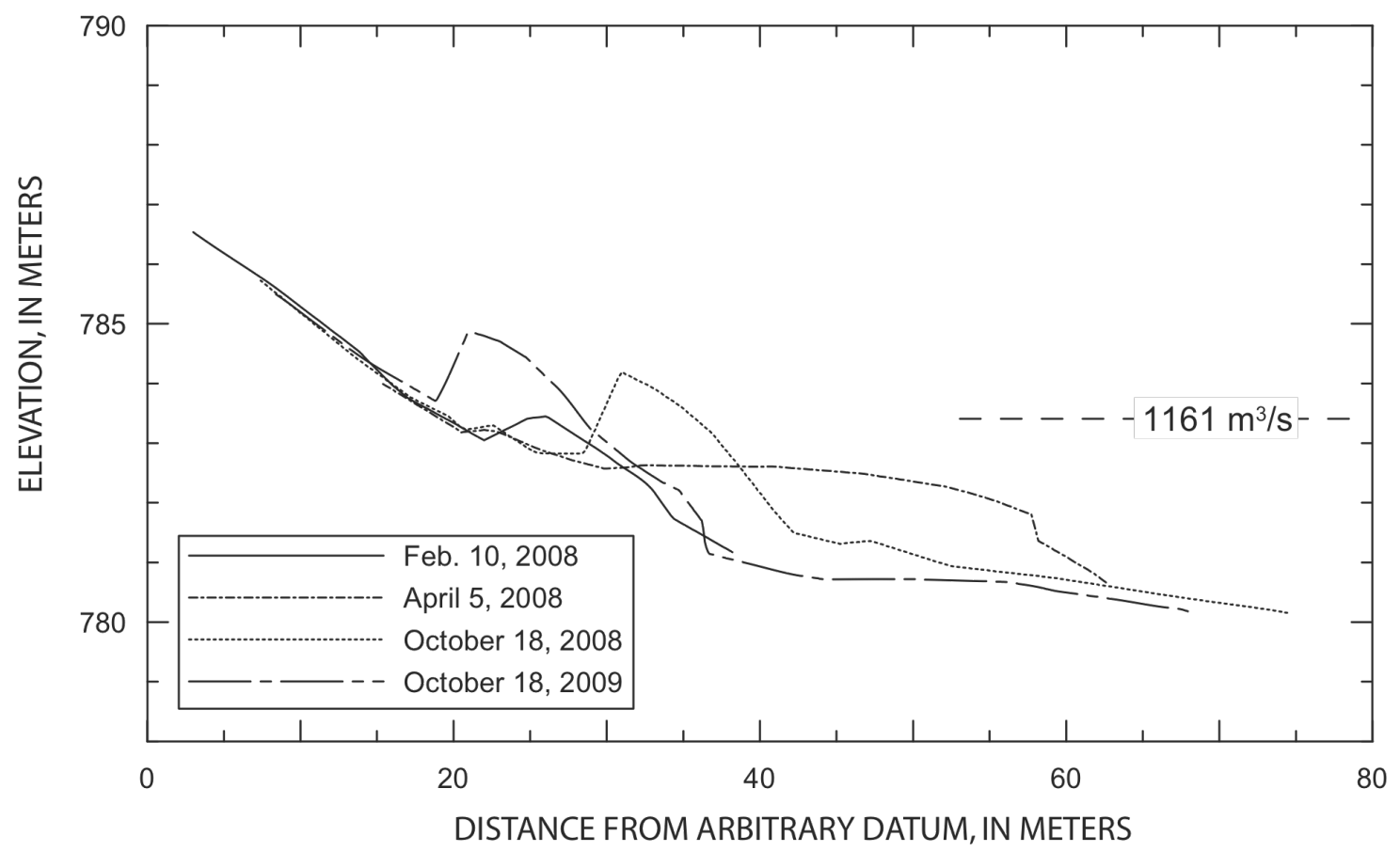

Figure 40. Surveyed shore-perpendicular profiles of the sandbar near AZ C:13:0321 before and three times after the 2008 High-Flow Experiment (HFE). The elevation of the HFE peak stage is indicated $\left(1,161 \mathrm{~m}^{3} / \mathrm{s}\right)$. Profiles trend approximately due north. Note that by October 2009, the entire dune form had migrated inland far enough to be landward of, upslope of, and at higher elevation than the peak stage reached by the HFE flow.
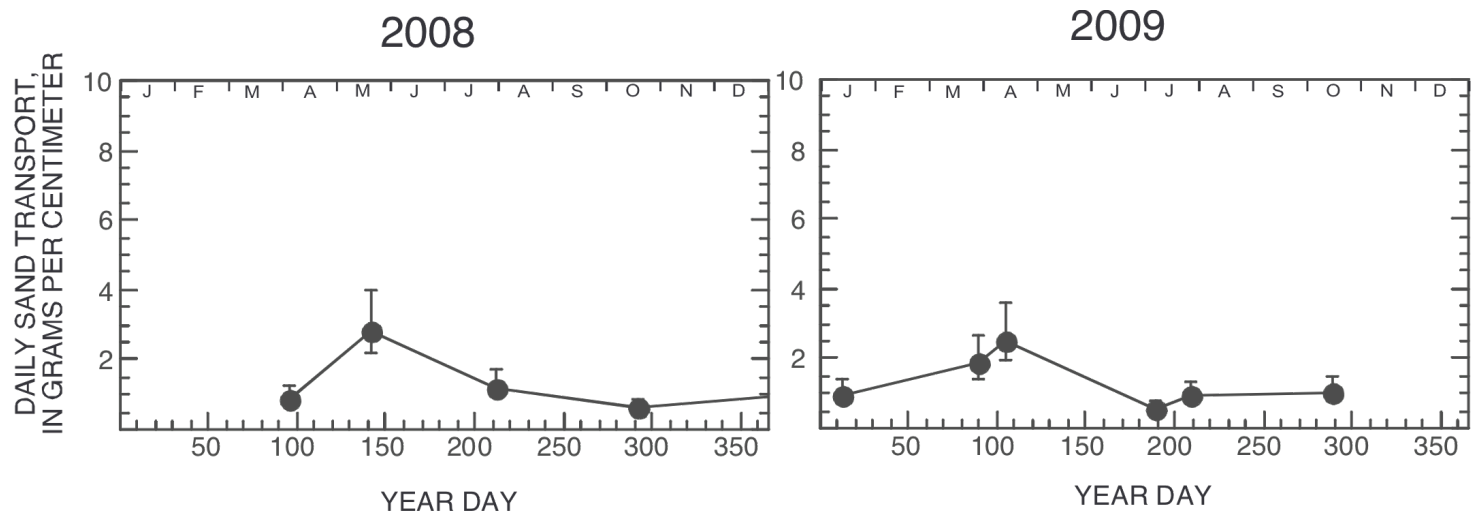

Figure 41. Aeolian sand-transport data collected near AZ C:13:0321 in 2008 and 2009. Daily sand transport is plotted in grams, normalized to a width of $1 \mathrm{~cm}$. To obtain these values, total sand mass collected from four traps during each maintenance visit was divided by number of days since traps had last been emptied. 


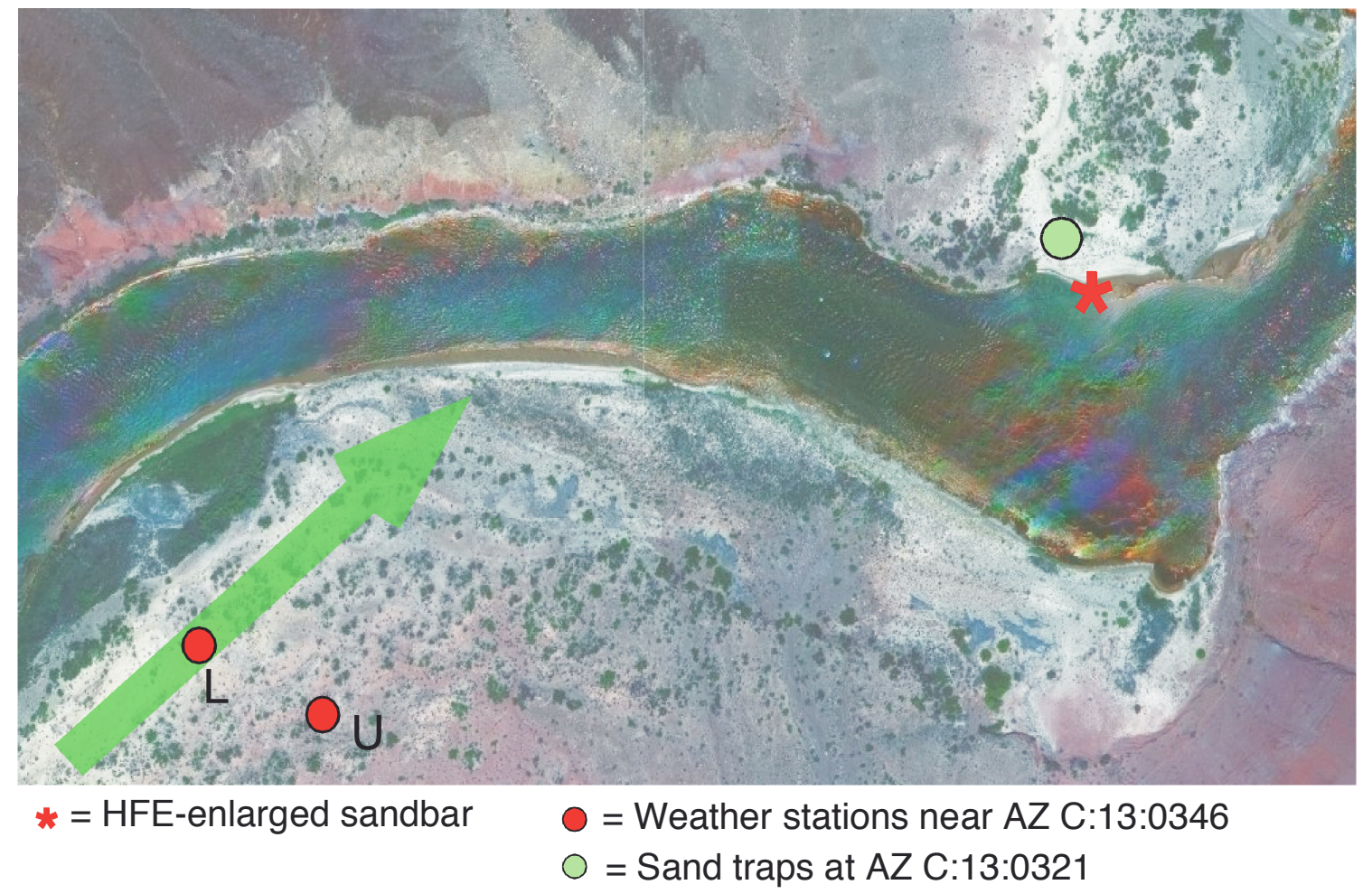

Figure 42. Aerial photograph of the area around AZ C:13:0346, in Grand Canyon, Ariz., with arrow indicating net direction of potential aeolian sediment transport measured at instrument station AZ C:13:0346 L in 2009. A vector sum of the $Q p$ proxy variable (equation 1), calculated using all available wind data collected during dry conditions from AZ C:13:0346 L in 2009 (excluding dates between May and late October when the station was not functioning), indicates net sediment transport from $228^{\circ}$. 


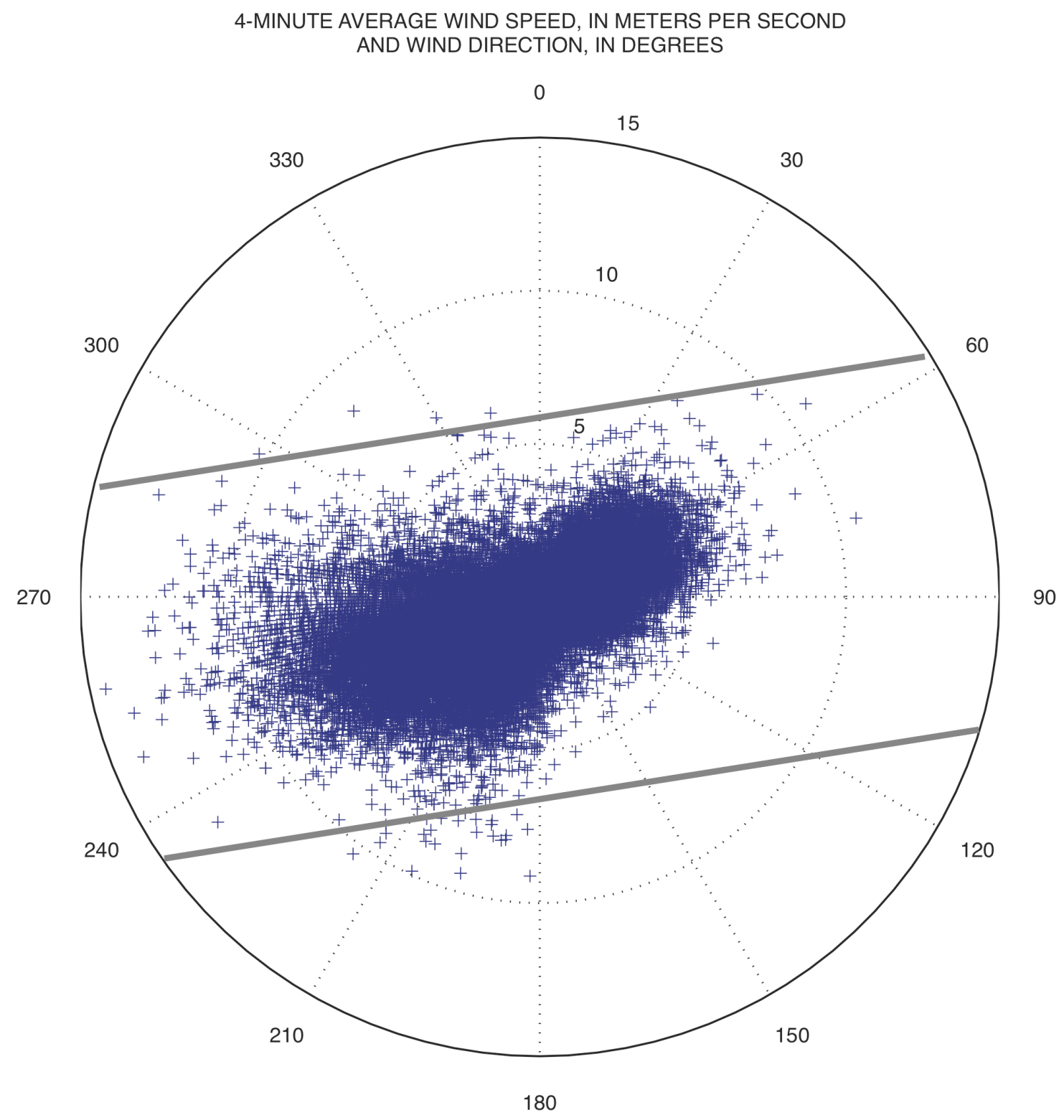

Figure 43. Magnitude and direction of wind velocity measured at the instrument station AZ C:13:0346 L in the Colorado River corridor, Grand Canyon, Ariz., at 4-minute resolution between January 1 and May 17 and between October 17 and December 31, 2009. Magnitude is indicated by the concentric circles, and compass bearing indicates direction from which the wind came. Parallel gray lines show the orientation of the canyon $\left(81^{\circ}\right)$; river flow is toward the west. 
STATION AZ C:13:0346 L

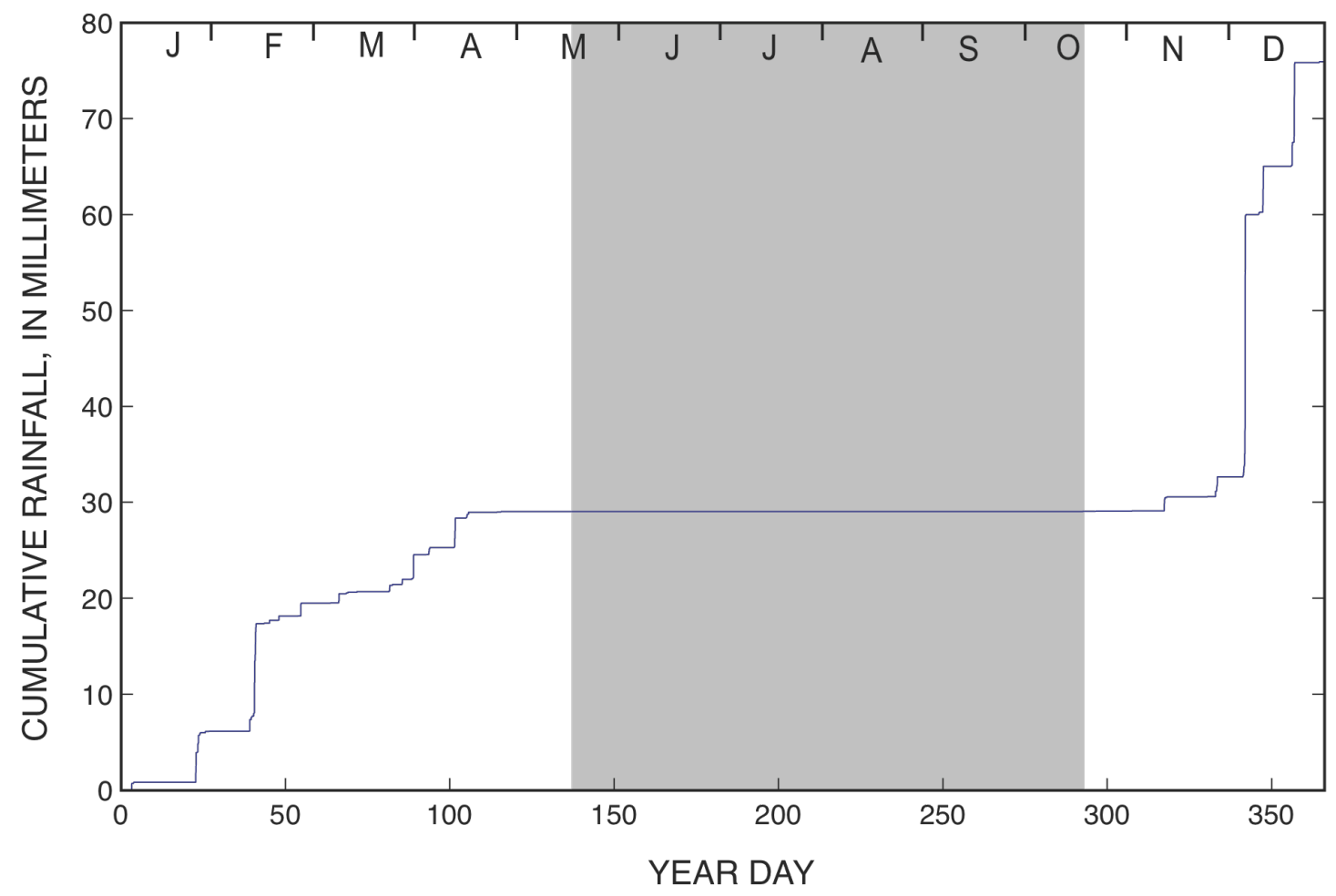

Figure 44. Cumulative 2009 rainfall record measured at AZ C:13:0346 L, compiled from data collected at 4-minute resolution. Gray-shaded region indicates days when the station was not collecting data. 

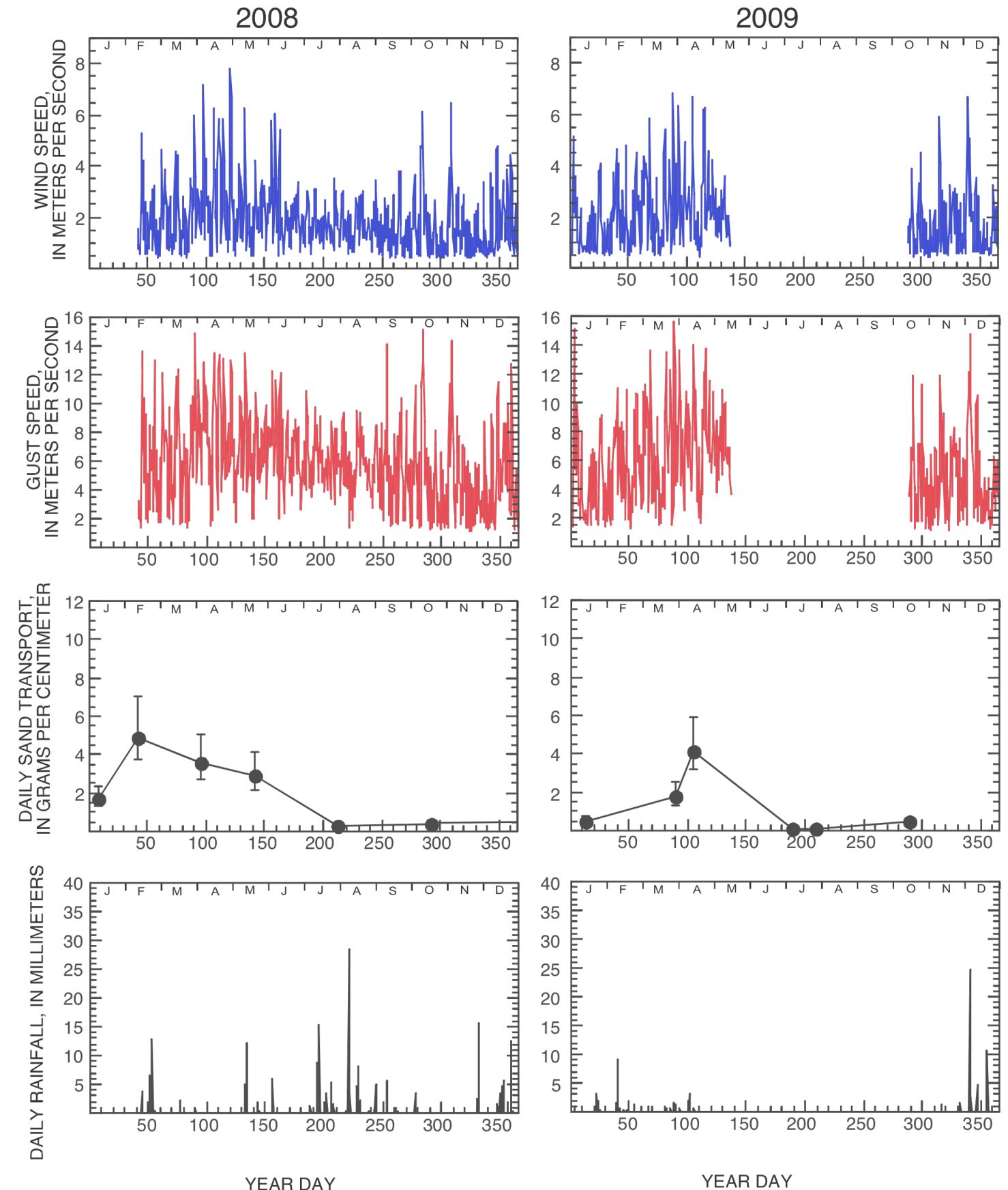

Figure 45. Wind, aeolian sand-transport, and rainfall data collected at the instrument station AZ C:13:0346 L in the Colorado River corridor, Grand Canyon, Ariz., in 2008 and 2009. Daily sand transport is plotted in grams, normalized to a width of $1 \mathrm{~cm}$. To obtain these values, total sand mass collected from four traps during each maintenance visit was divided by number of days since traps had last been emptied. Wind speed (blue plot) is presented as diurnal average values, using daytime $(0600-1800 \mathrm{~h})$ and nighttime $(1800-0600 \mathrm{~h})$ averages of data collected at 4-minute intervals. Gust speed (red plot) is shown as maximum values that occurred during each diurnal interval. Rainfall is plotted 
as daily (24-hour) totals. Data gaps indicate times when the data logger at this station was not functioning (between May 17 and October 17, year days 137-290).
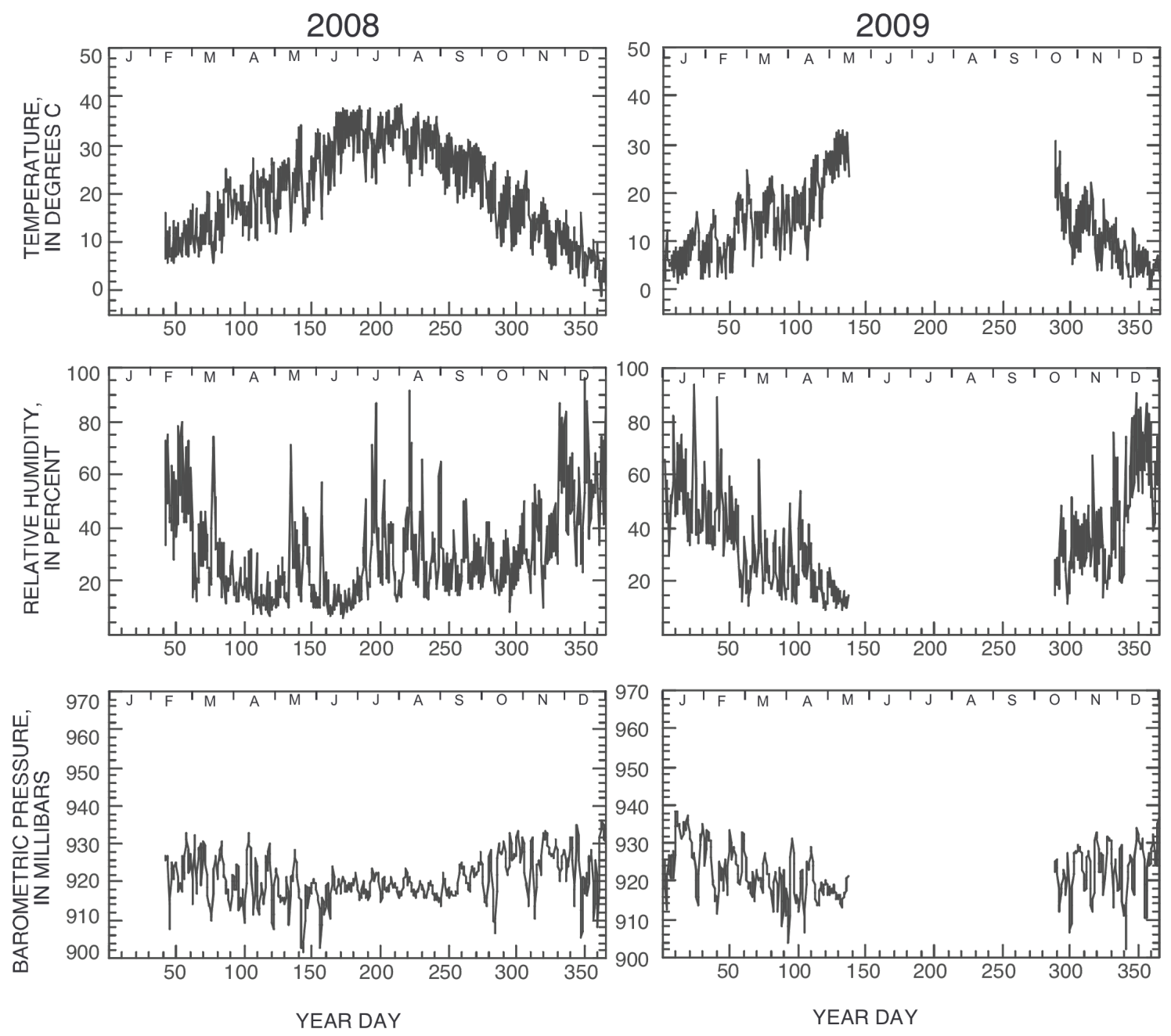

Figure 46. Temperature, humidity, and barometric pressure data collected at the instrument station AZ C:13:0346 L in the Colorado River corridor, Grand Canyon, Ariz., in 2008 and 2009. All parameters are plotted as diurnal averages (defined using 0600-1800 and 1800-0600 h). Data gaps indicate times when the data logger at this station was not functioning (between May 17 and October 17, year days 137-290). 


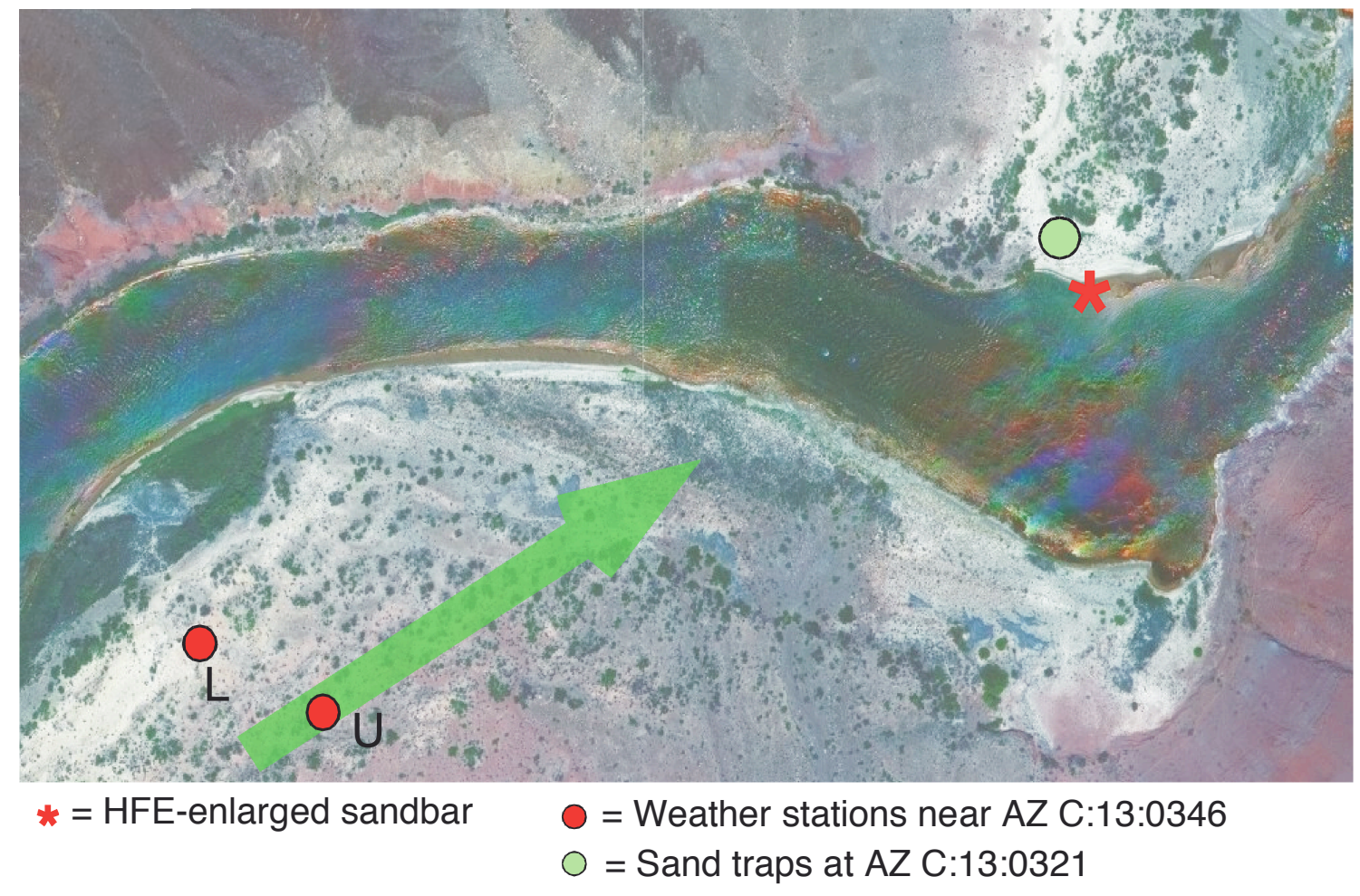

Figure 47. Aerial photograph of the area around AZ C:13:0346, in Grand Canyon, Ariz., with arrow indicating net direction of potential aeolian sediment transport measured at instrument station AZ C:13:0346 U in 2009. A vector sum of the $Q p$ proxy variable (equation 1), calculated using all wind data collected during dry conditions from AZ $\mathrm{C}: 13: 0346 \mathrm{U}$ in 2009 , indicates net sediment transport from $237^{\circ}$. 


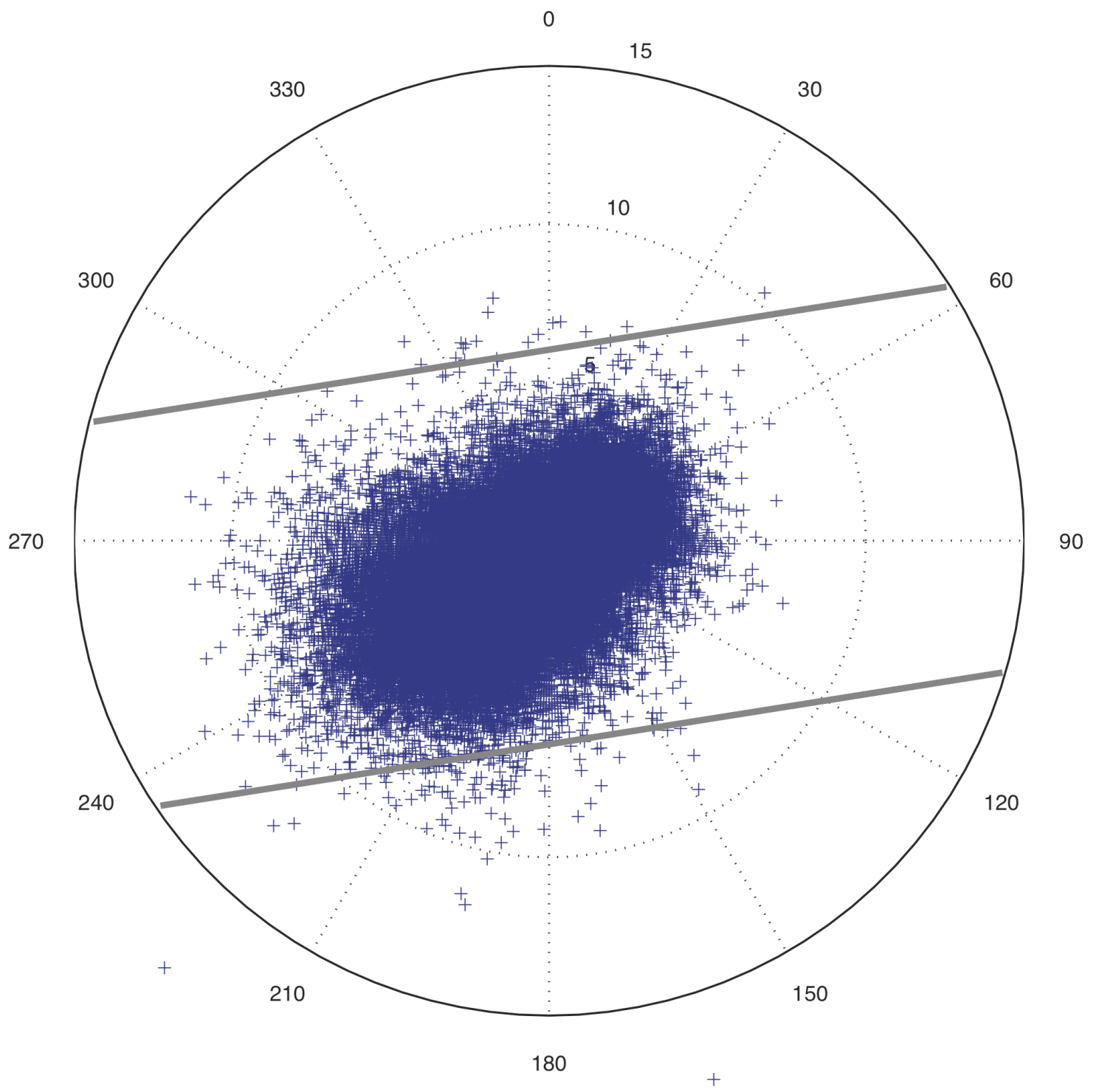

Figure 48. Magnitude and direction of wind velocity measured at the instrument station AZ C:13:0346 U in the Colorado River corridor, Grand Canyon, Ariz., at 4-minute resolution throughout 2009. Magnitude is indicated by the concentric circles, and compass bearing indicates direction from which the wind came. Parallel gray lines show the orientation of the canyon $\left(81^{\circ}\right)$; river flow is toward the west. 
STATION AZ C:13:0346 U

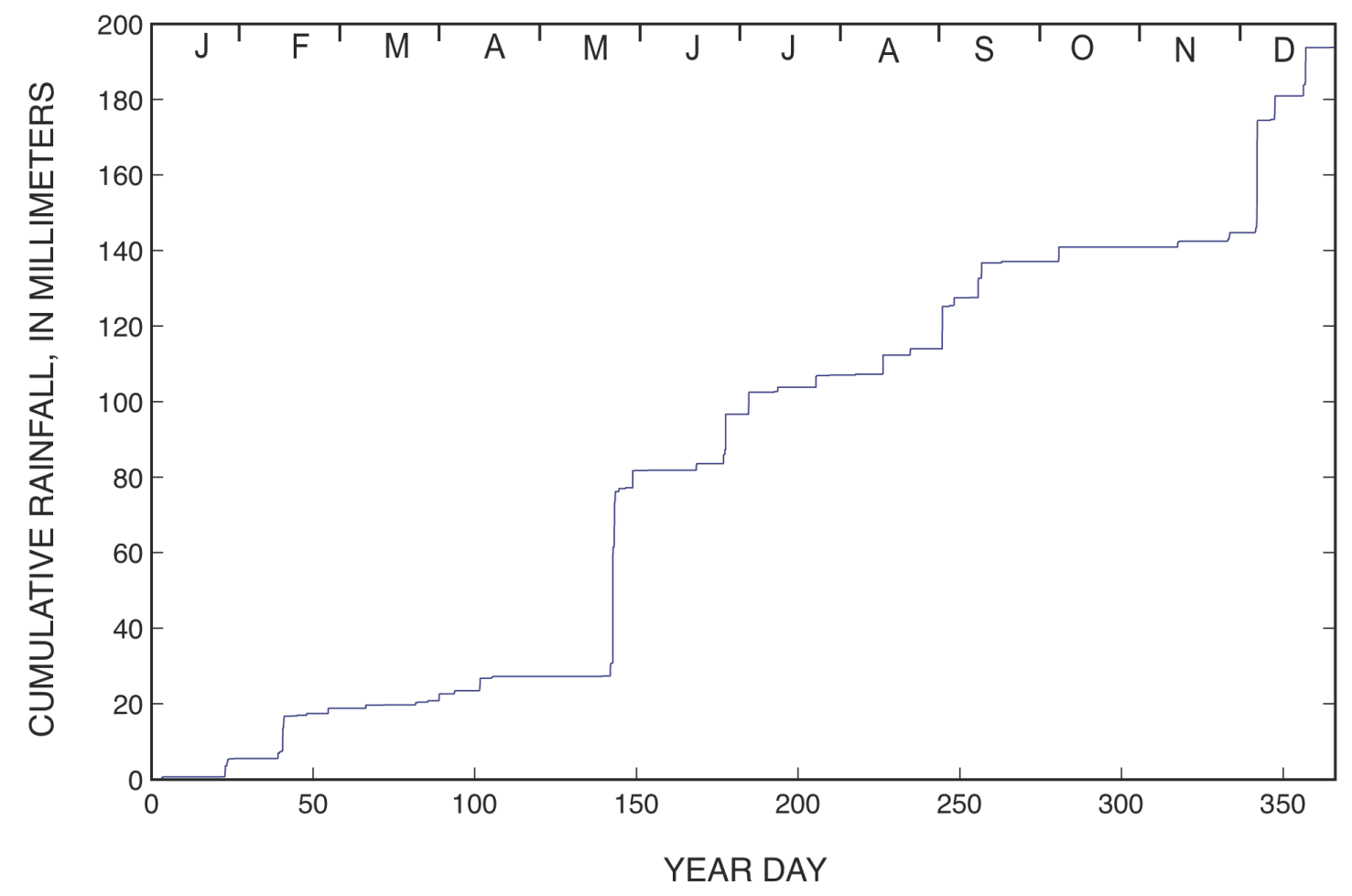

Figure 49. Cumulative 2009 rainfall record measured at AZ C:13:0346 U, compiled from data collected at 4-minute resolution. 

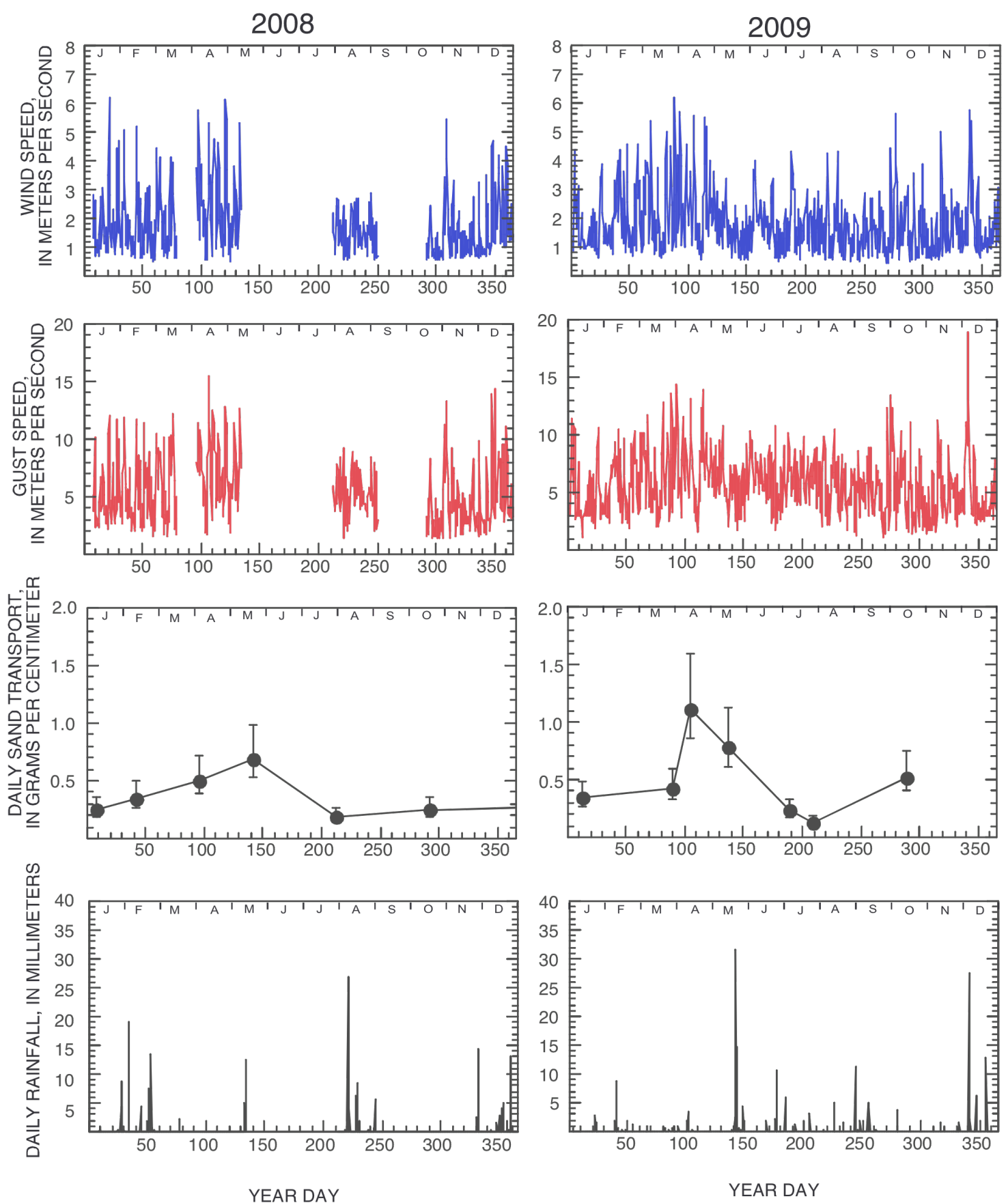

Figure 50. Wind, aeolian sand-transport, and rainfall data collected at the instrument station AZ C:13:0346 U in the Colorado River corridor, Grand Canyon, Ariz., in 2008 and 2009. Daily sand transport is plotted in grams, normalized to a width of $1 \mathrm{~cm}$. To obtain these values, total sand mass collected from four traps during each maintenance visit was divided by number of days since traps had last been emptied. Wind speed (blue plot) is presented as diurnal average values, using daytime (0600-1800 h) and nighttime (1800-0600 h) averages of data collected at 4-minute intervals. Gust speed (red plot) is shown as maximum values that occurred during each diurnal interval. Rainfall is plotted as daily (24-hour) totals. 

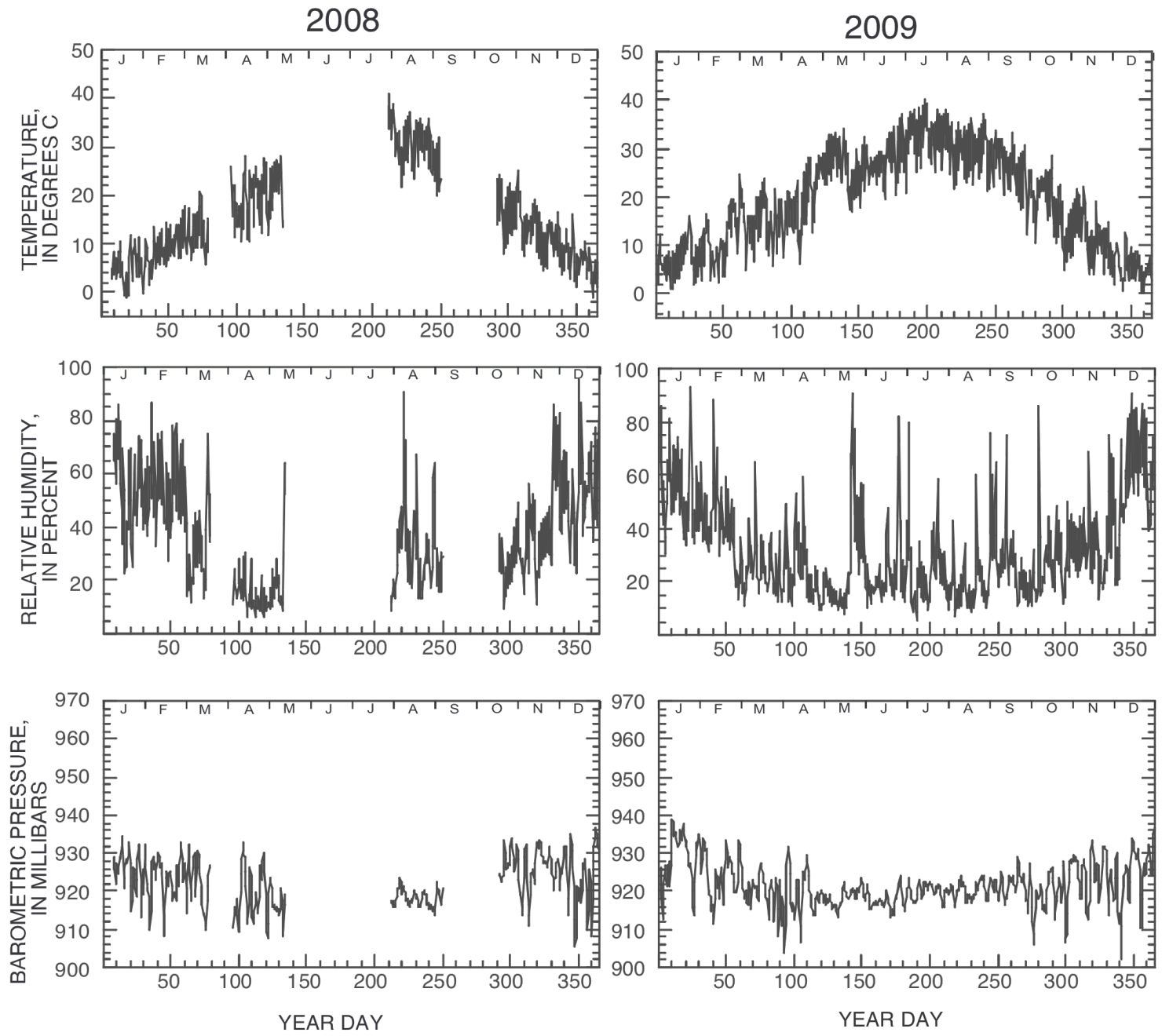

Figure 51. Temperature, humidity, and barometric pressure data collected at the instrument station AZ C:13:0346 U in the Colorado River corridor, Grand Canyon, Ariz., in 2008 and 2009. All parameters are plotted as diurnal averages (defined using 0600-1800 and 1800-0600 h). 


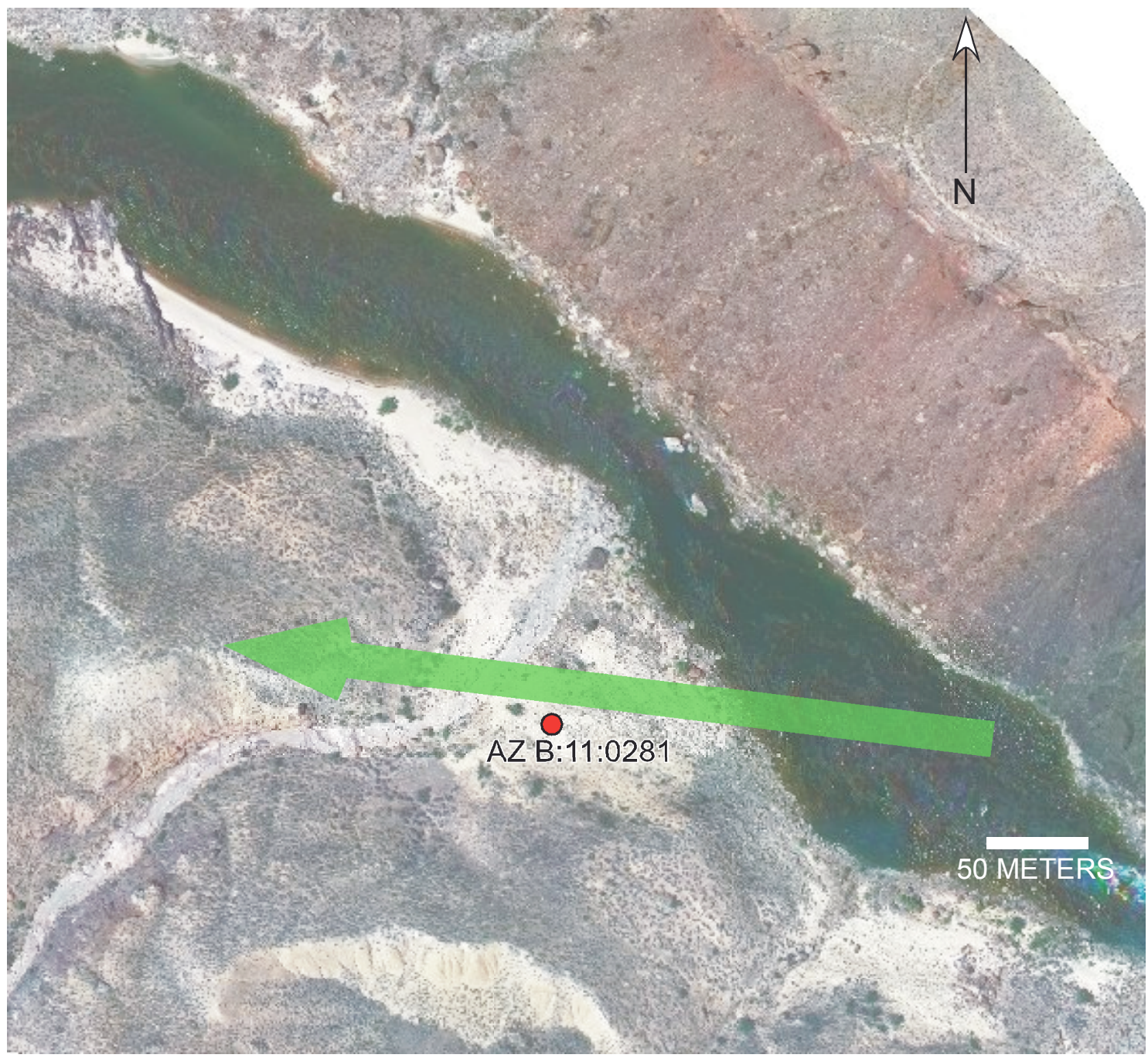

Figure 52. Aerial photograph of the area around the instrument station near AZ B:11:0281, in Grand Canyon, Ariz., with arrow indicating net direction of potential aeolian sediment transport measured in 2009. A vector sum of the $Q p$ proxy variable (equation 1), calculated using all wind data collected during dry conditions from AZ B:11:0281 in 2009, indicates net sediment transport from $97^{\circ}$. 


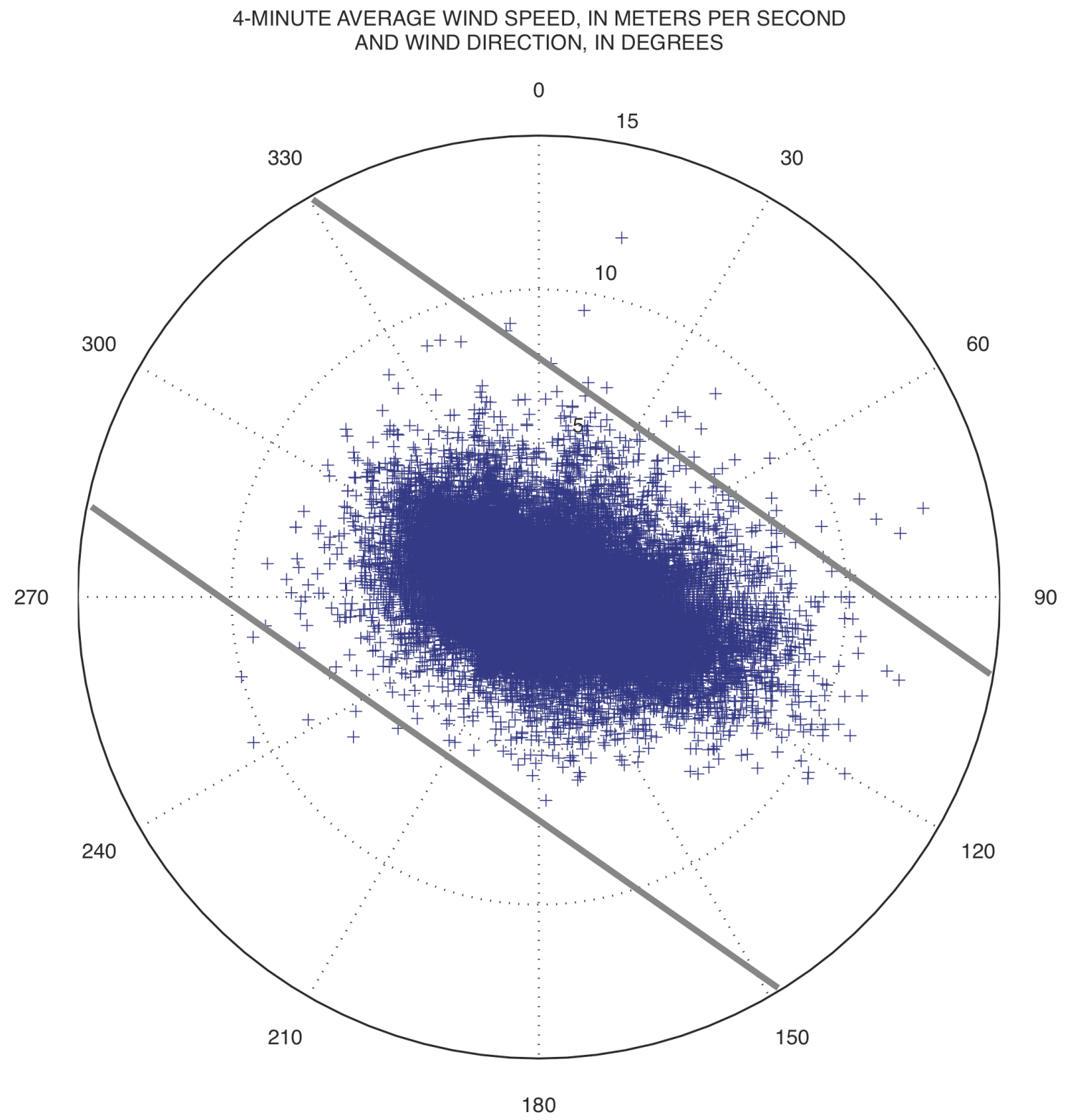

Figure 53. Magnitude and direction of wind velocity measured at the instrument station AZ B:11:0281 in the Colorado River corridor, Grand Canyon, Ariz., at 4-minute resolution throughout 2009. Magnitude is indicated by the concentric circles, and compass bearing indicates direction from which the wind came. Parallel gray lines show the orientation of the canyon $\left(305^{\circ}\right)$; river flow is toward the northwest. 
STATION AZ B:11:0281

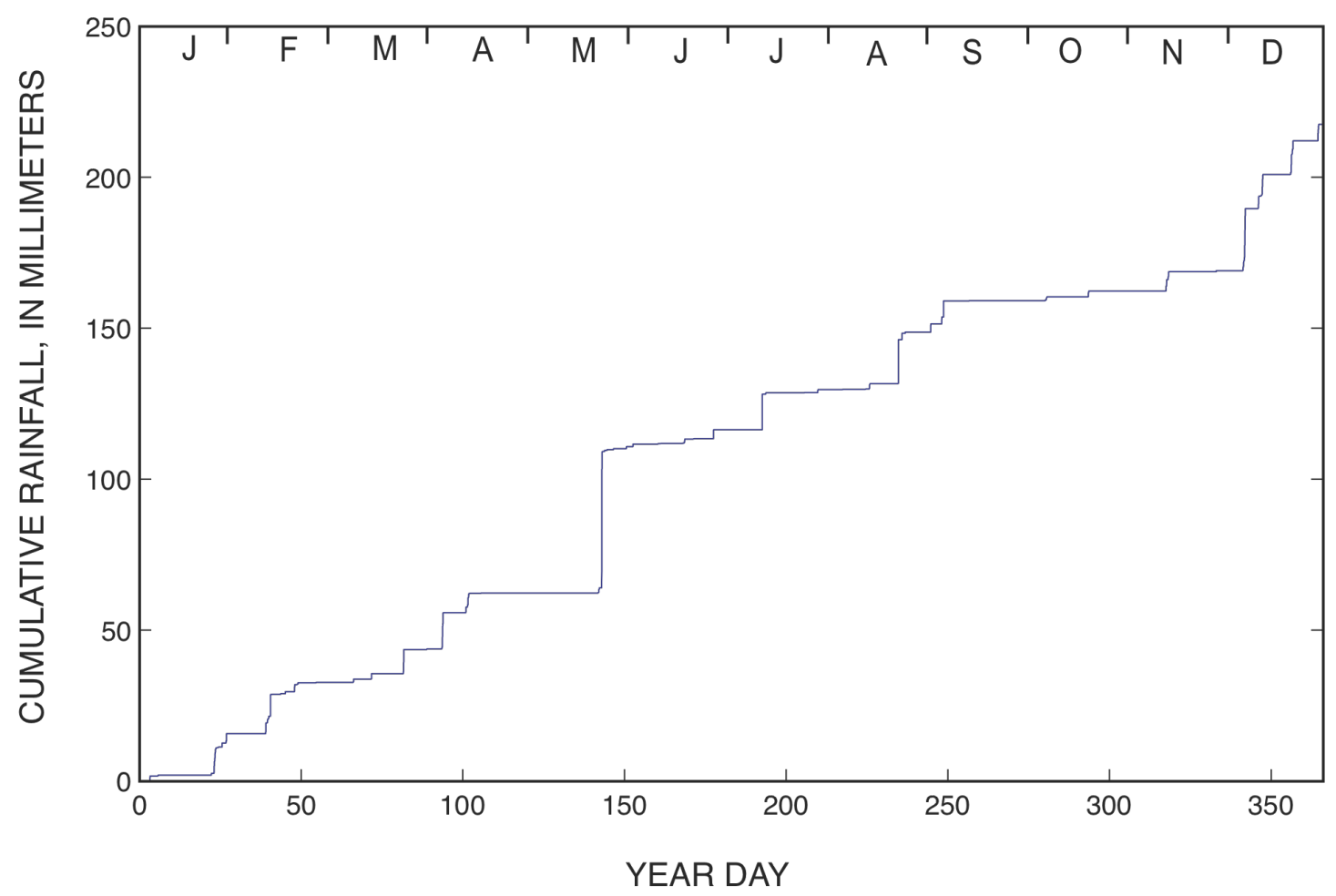

Figure 54. Cumulative 2009 rainfall record measured at AZ B:11:0281, compiled from data collected at 4-minute resolution. 

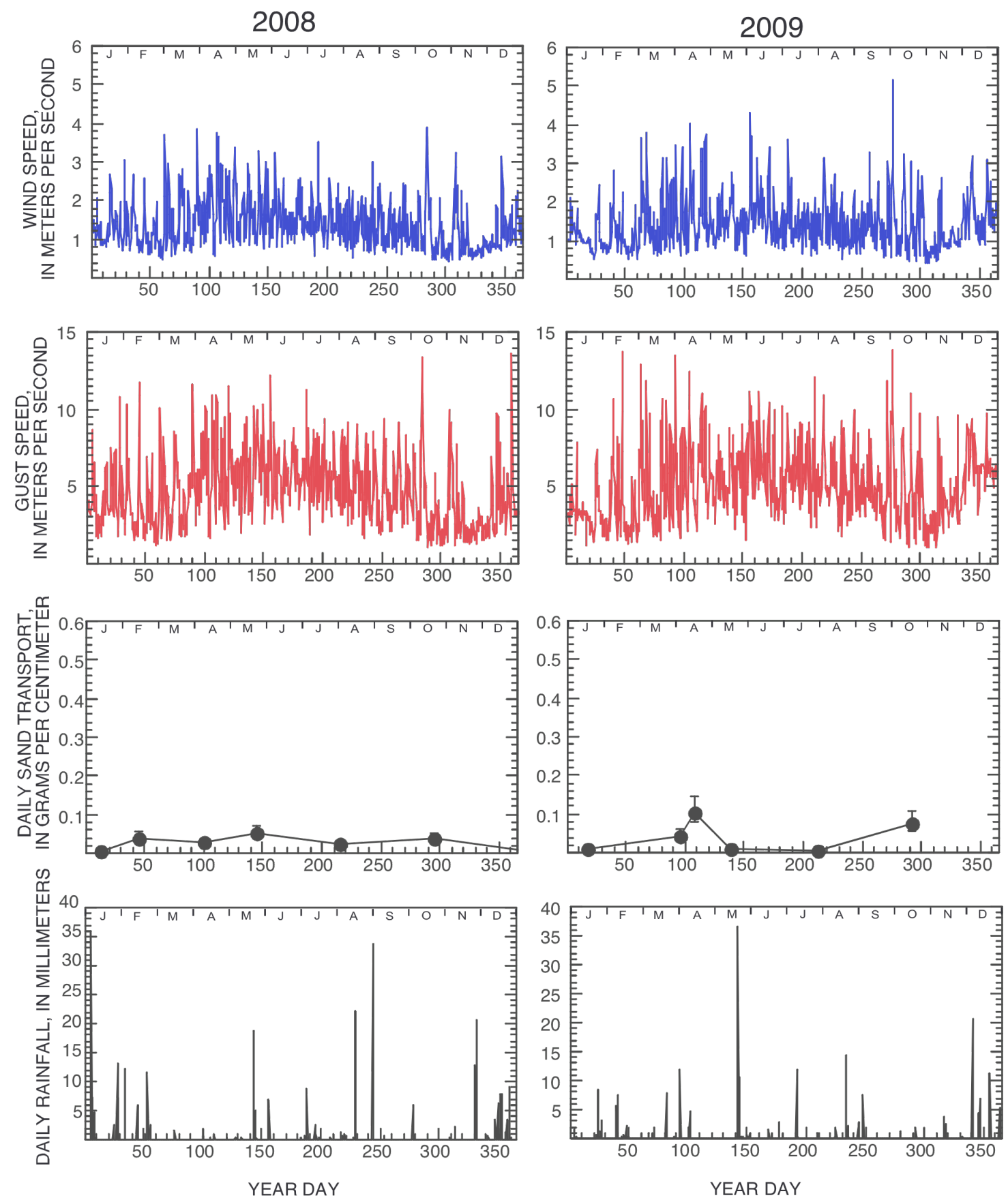

Figure 55. Wind, aeolian sand-transport, and rainfall data collected at the instrument station AZ B:11:0281 in the Colorado River corridor, Grand Canyon, Ariz., in 2008 and 2009. Daily sand transport is plotted in grams, normalized to a width of $1 \mathrm{~cm}$. To obtain these values, total sand mass collected from four traps during each maintenance visit was divided by number of days since traps had last been emptied. Wind speed (blue plot) is presented as diurnal average values, using daytime (0600-1800 h) and nighttime (1800$0600 \mathrm{~h}$ ) averages of data collected at 4-minute intervals. Gust speed (red plot) is shown as maximum values that occurred during each diurnal interval. Rainfall is plotted as daily (24-hour) totals. 

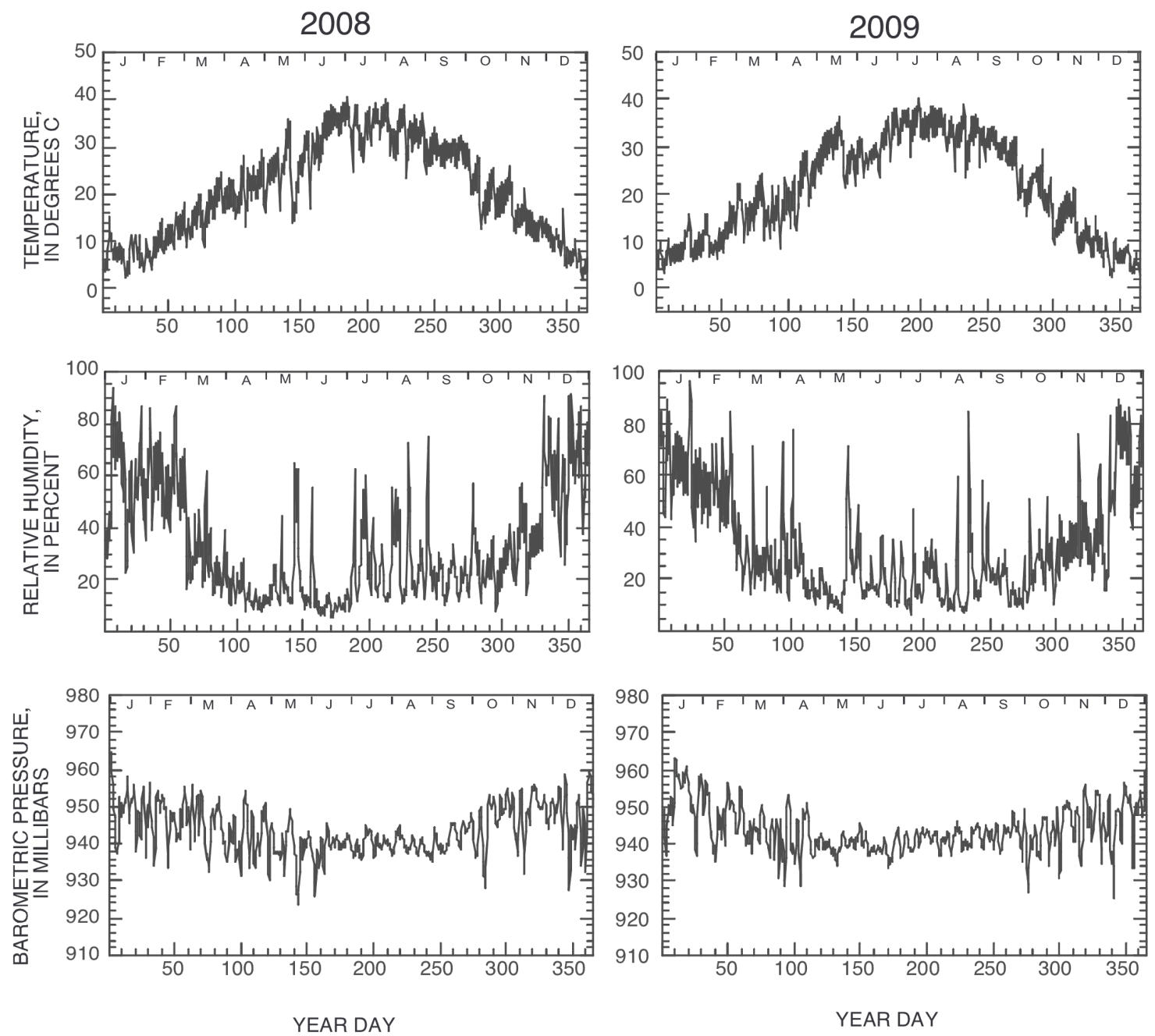

Figure 56. Temperature, humidity, and barometric pressure data collected at the instrument station AZ B:11:0281 in the Colorado River corridor, Grand Canyon, Ariz., in 2008 and 2009. All parameters are plotted as diurnal averages (defined using 0600-1800 and $1800-0600 \mathrm{~h}$ ). 


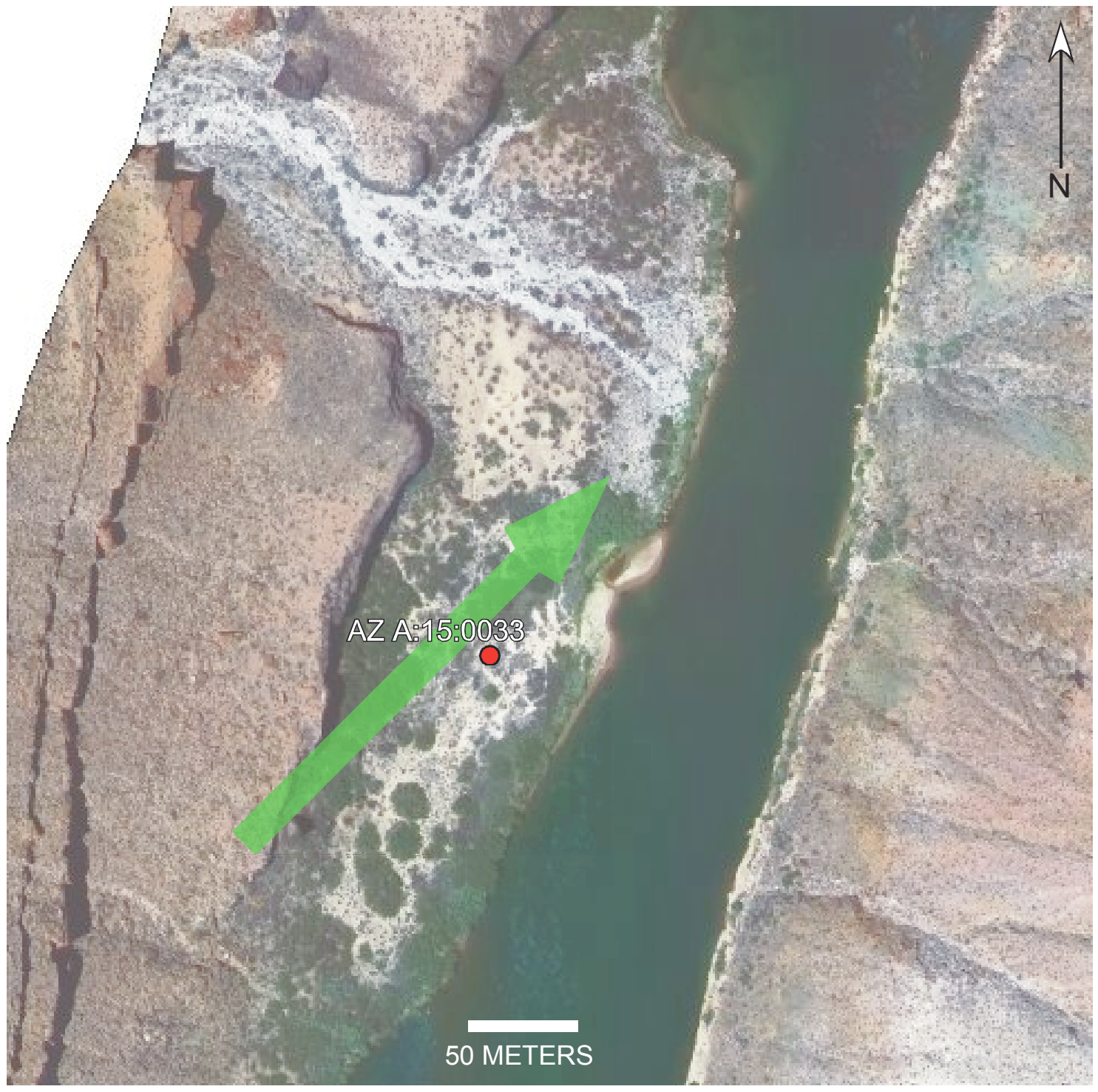

Figure 57. Aerial photograph of the area around the instrument station near AZ A:15:0033, in Grand Canyon, Ariz., with arrow indicating net direction of potential aeolian sediment transport measured in 2009. A vector sum of the $Q p$ proxy variable (equation 1), calculated using all wind data during dry conditions from AZ A:15:0033 in 2009, indicates net sediment transport from $225^{\circ}$. 


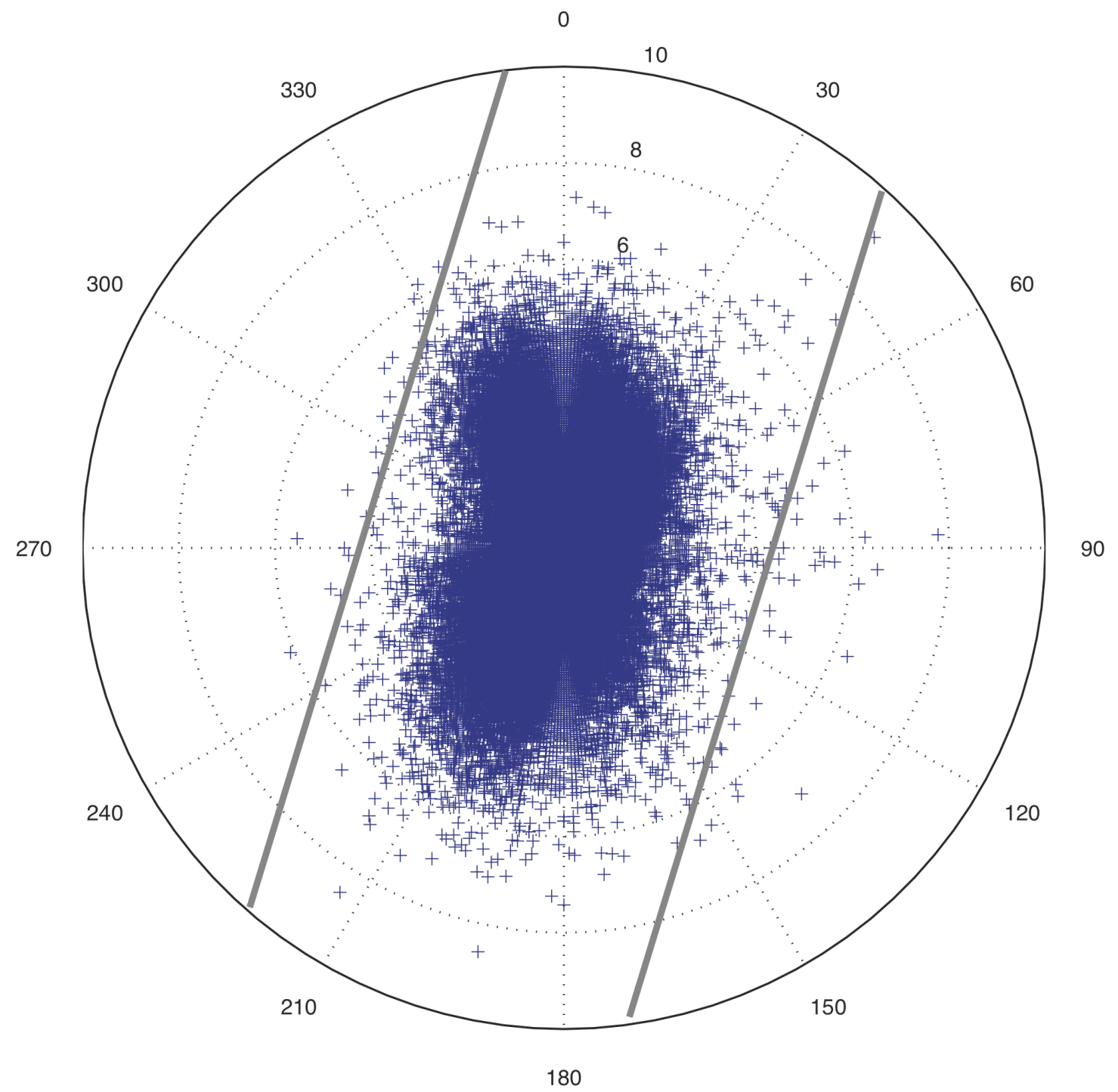

Figure 58. Magnitude and direction of wind velocity measured at the instrument station AZ A:15:0033 in the Colorado River corridor, Grand Canyon, Ariz., at 4-minute resolution throughout 2009. Magnitude is indicated by the concentric circles, and compass bearing indicates direction from which the wind came. Parallel gray lines show the orientation of the canyon $\left(17^{\circ}\right)$; river flow is toward the south. 


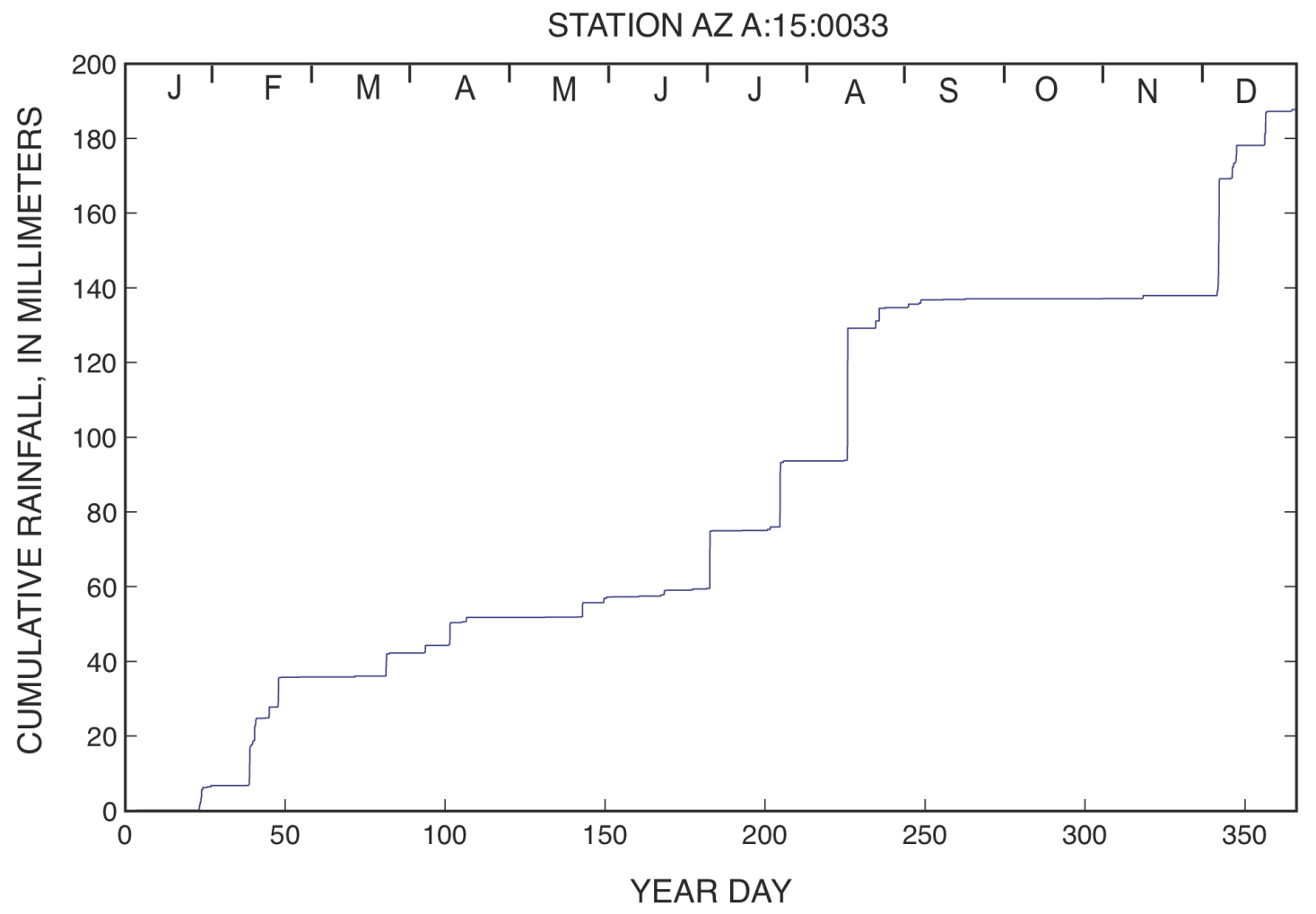

Figure 59. Cumulative 2009 rainfall record measured at AZ A:15:0033, compiled from data collected at 4-minute resolution. 

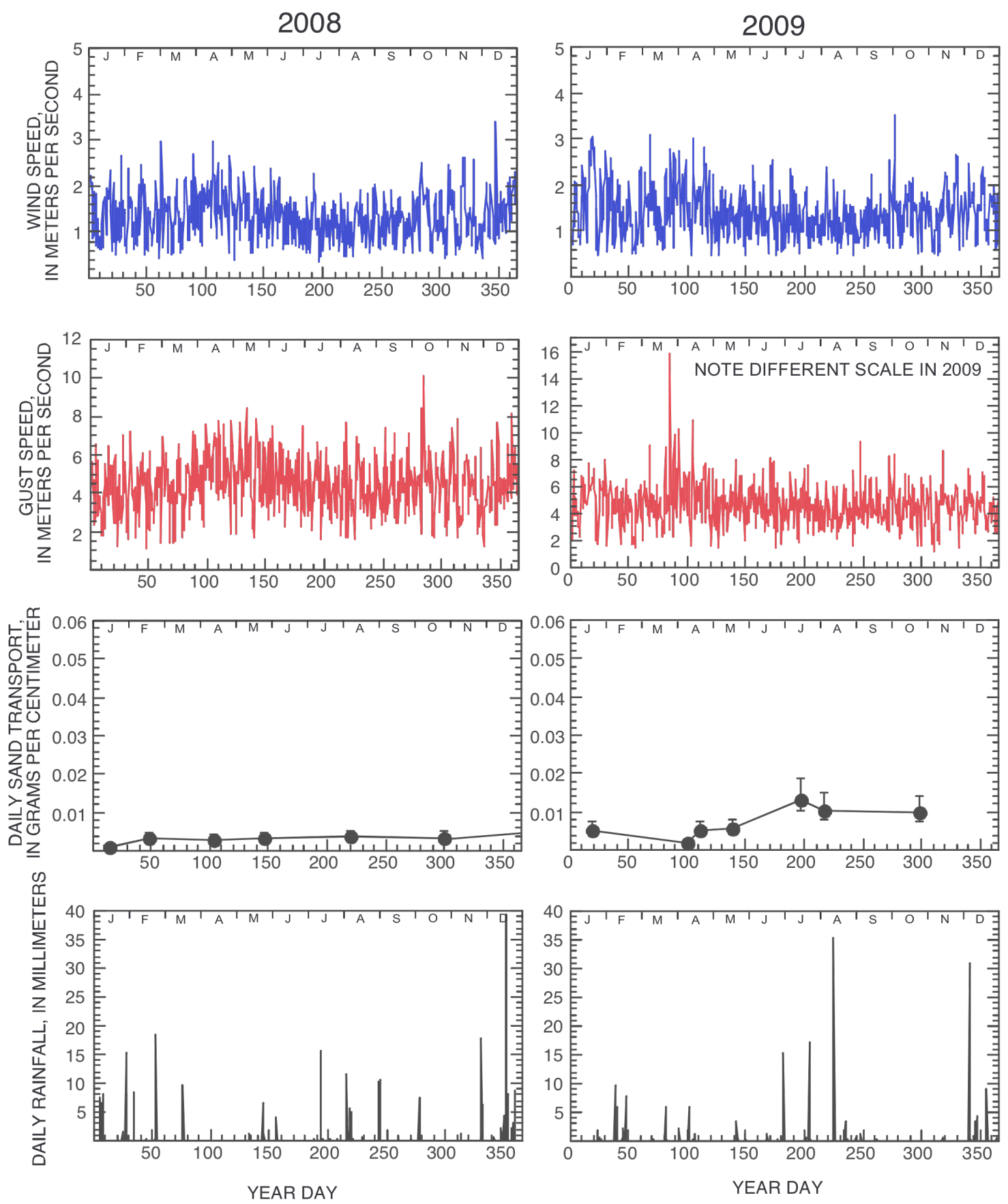

Figure 60. Wind, aeolian sand-transport, and rainfall data collected at the instrument station AZ A:15:0033 in the Colorado River corridor, Grand Canyon, Ariz., in 2008 and 2009. Daily sand transport is plotted in grams, normalized to a width of $1 \mathrm{~cm}$. To obtain these values, total sand mass collected from four traps during each maintenance visit was divided by number of days since traps had last been emptied. Wind speed (blue plot) is presented as diurnal average values, using daytime (0600-1800 h) and nighttime (1800$0600 \mathrm{~h}$ ) averages of data collected at 4-minute intervals. Gust speed (red plot) is shown as maximum values that occurred during each diurnal interval. Rainfall is plotted as daily (24-hour) totals. 

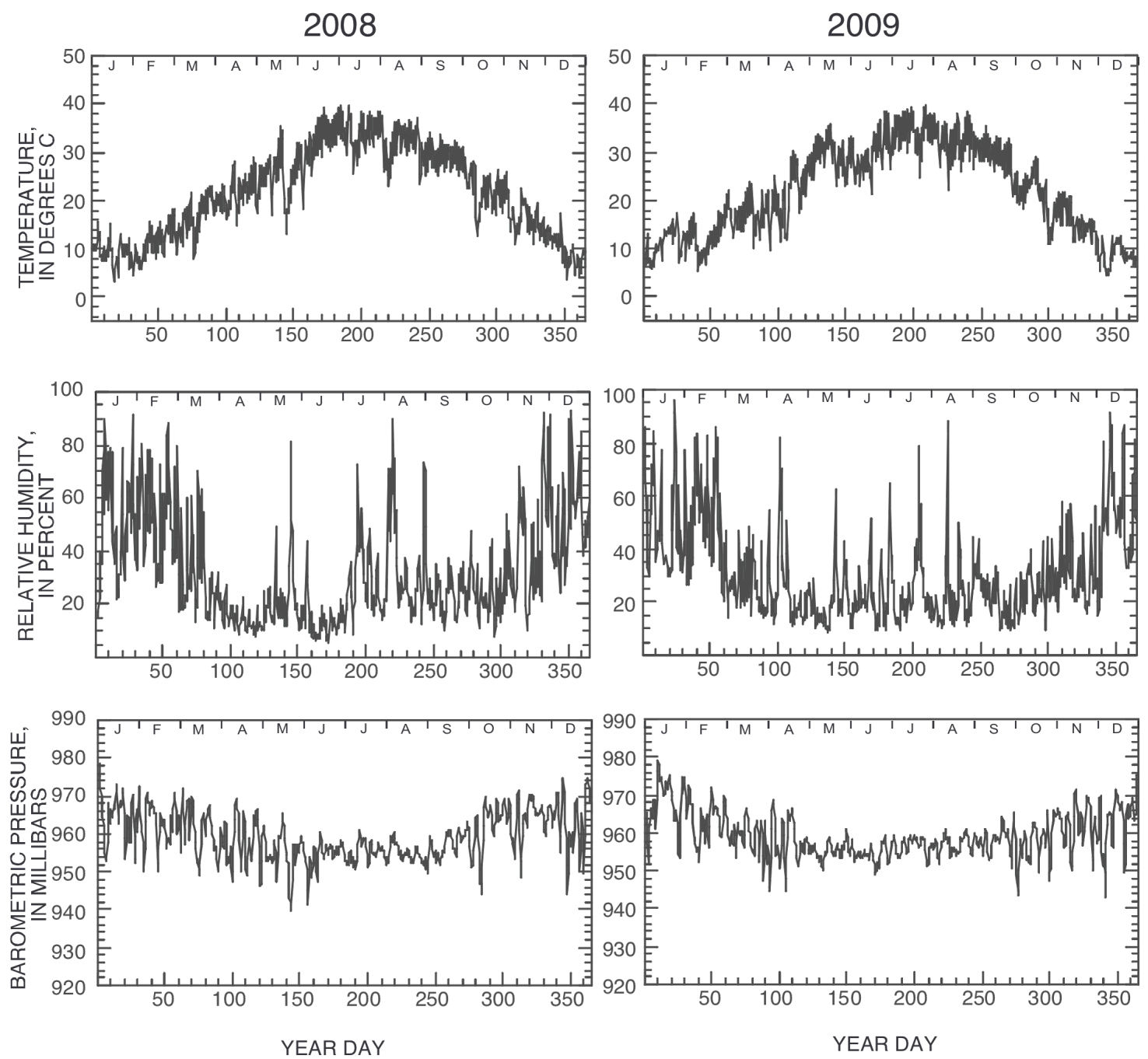

Figure 61. Temperature, humidity, and barometric pressure data collected at the instrument station AZ A:15:0033 in the Colorado River corridor, Grand Canyon, Ariz., in 2008 and 2009. All parameters are plotted as diurnal averages (defined using 0600-1800 and $1800-0600 \mathrm{~h})$. 


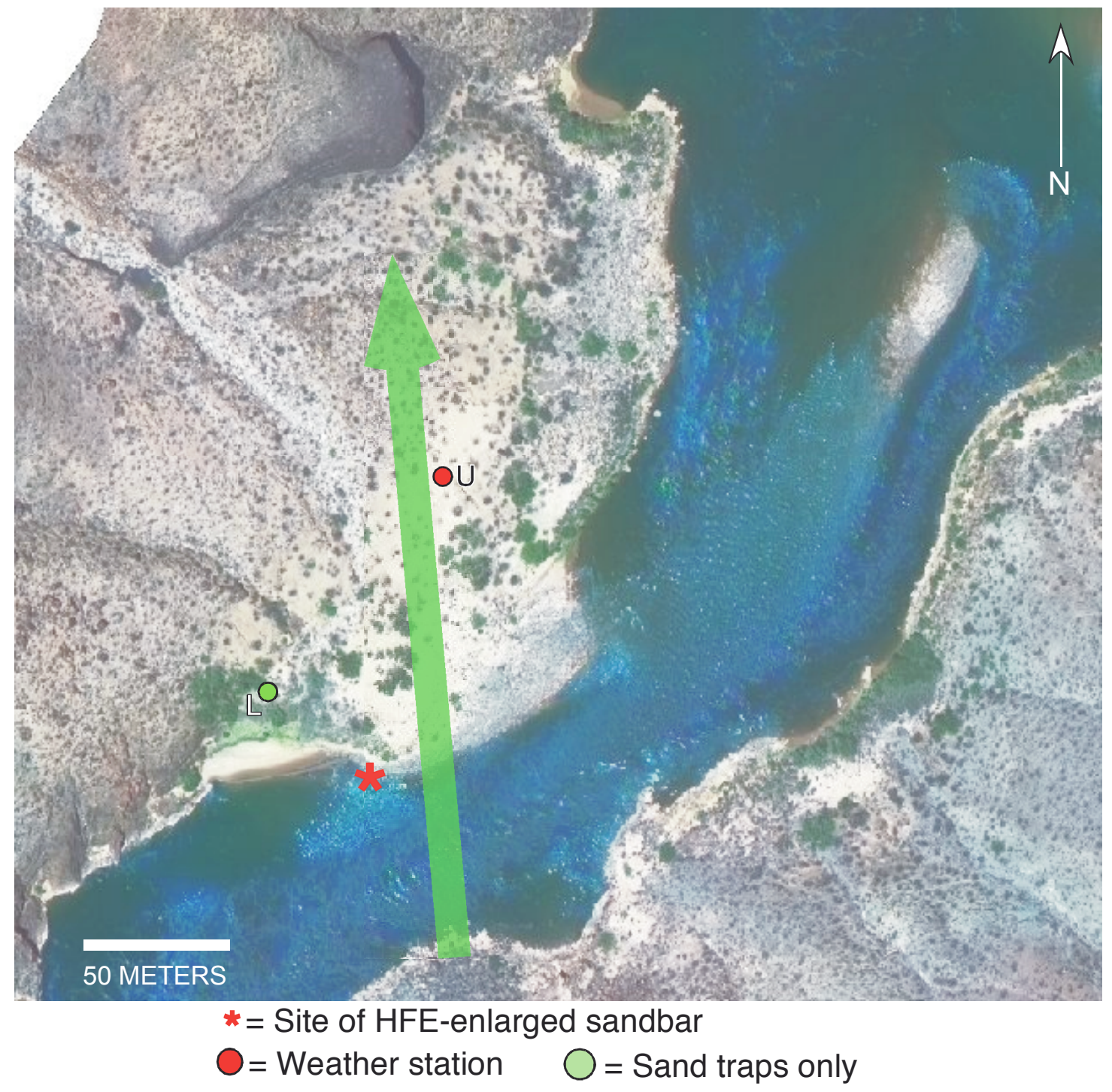

Figure 62. Aerial photograph of the area around the instrument station near AZ G:03:0072, in Grand Canyon, Ariz., with arrow indicating net direction of potential aeolian sediment transport measured at AZ G:03:0072 U in 2009. A vector sum of the $Q p$ proxy variable (equation 1), calculated using all wind data collected during dry conditions from AZ G:03:0072 U in 2009, indicates net sediment transport from $175^{\circ}$. 


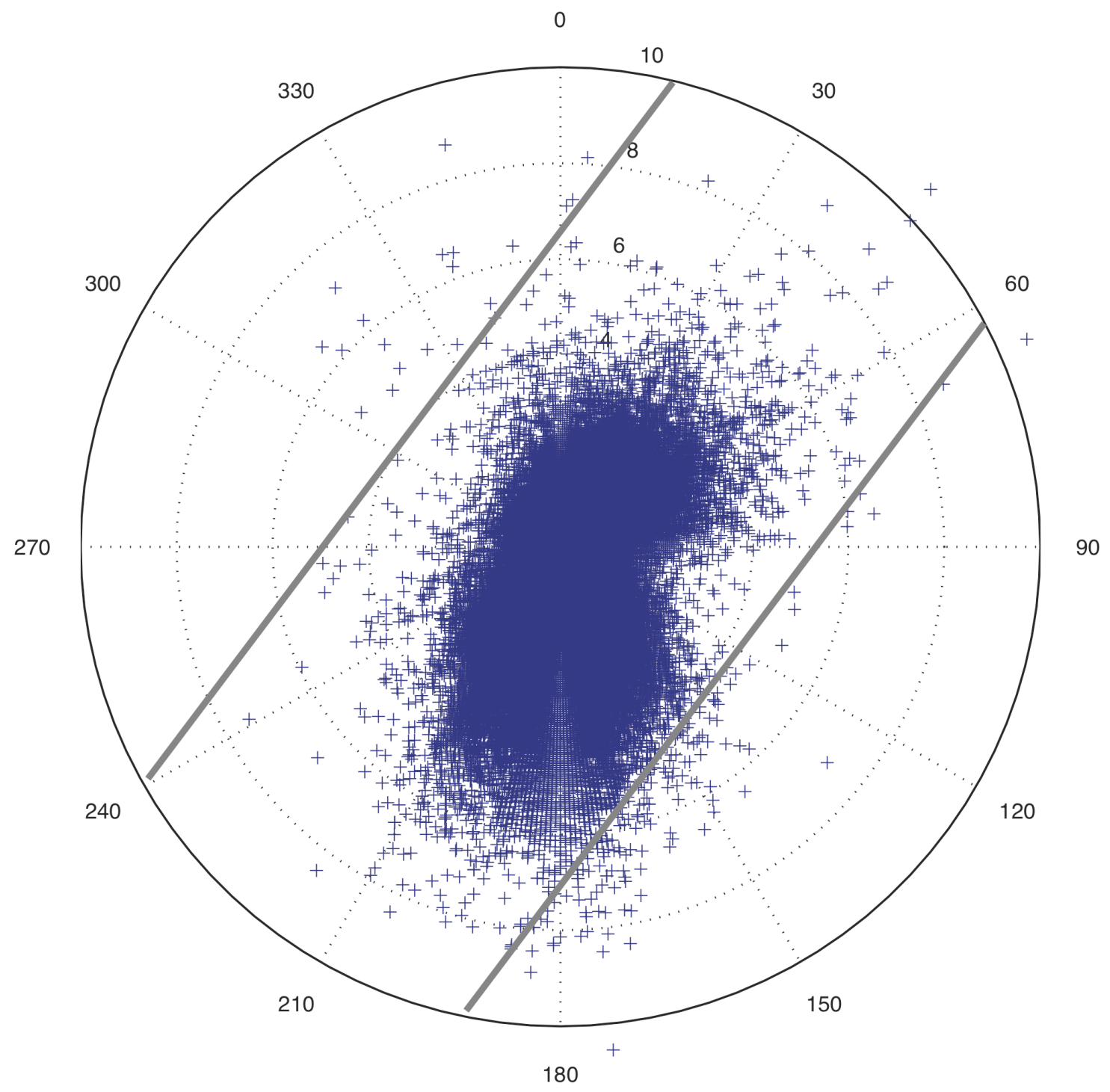

Figure 63. Magnitude and direction of wind velocity measured at the instrument station AZ G:03:0072 U in the Colorado River corridor, Grand Canyon, Ariz., at 4-minute resolution throughout 2009. Magnitude is indicated by the concentric circles, and compass bearing indicates direction from which the wind came. Parallel gray lines show the orientation of the canyon ( 37 degrees); river flow is toward the southwest. 


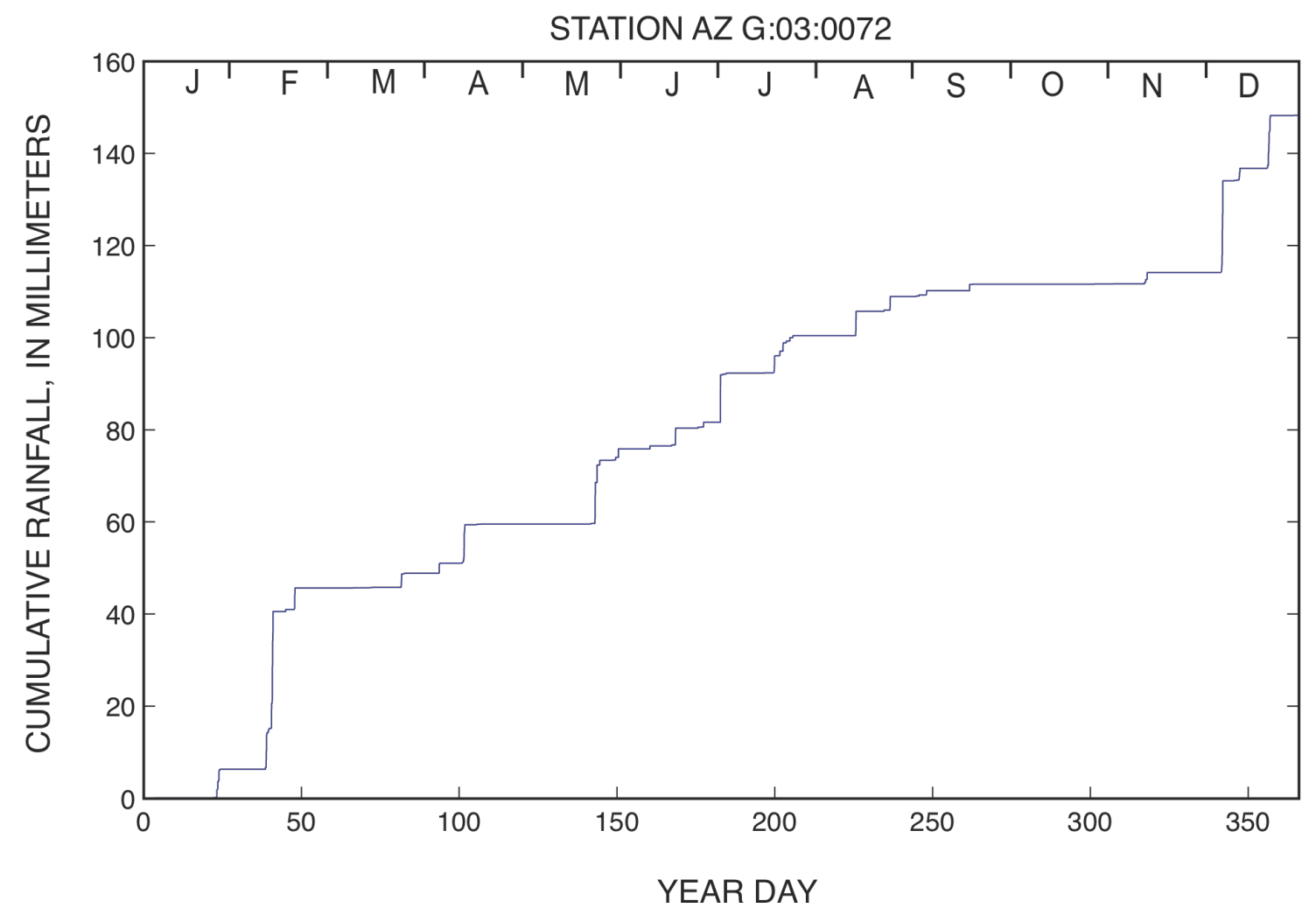

Figure 64. Cumulative 2009 rainfall record measured at AZ G:03:0072 U, compiled from data collected at 4-minute resolution. 

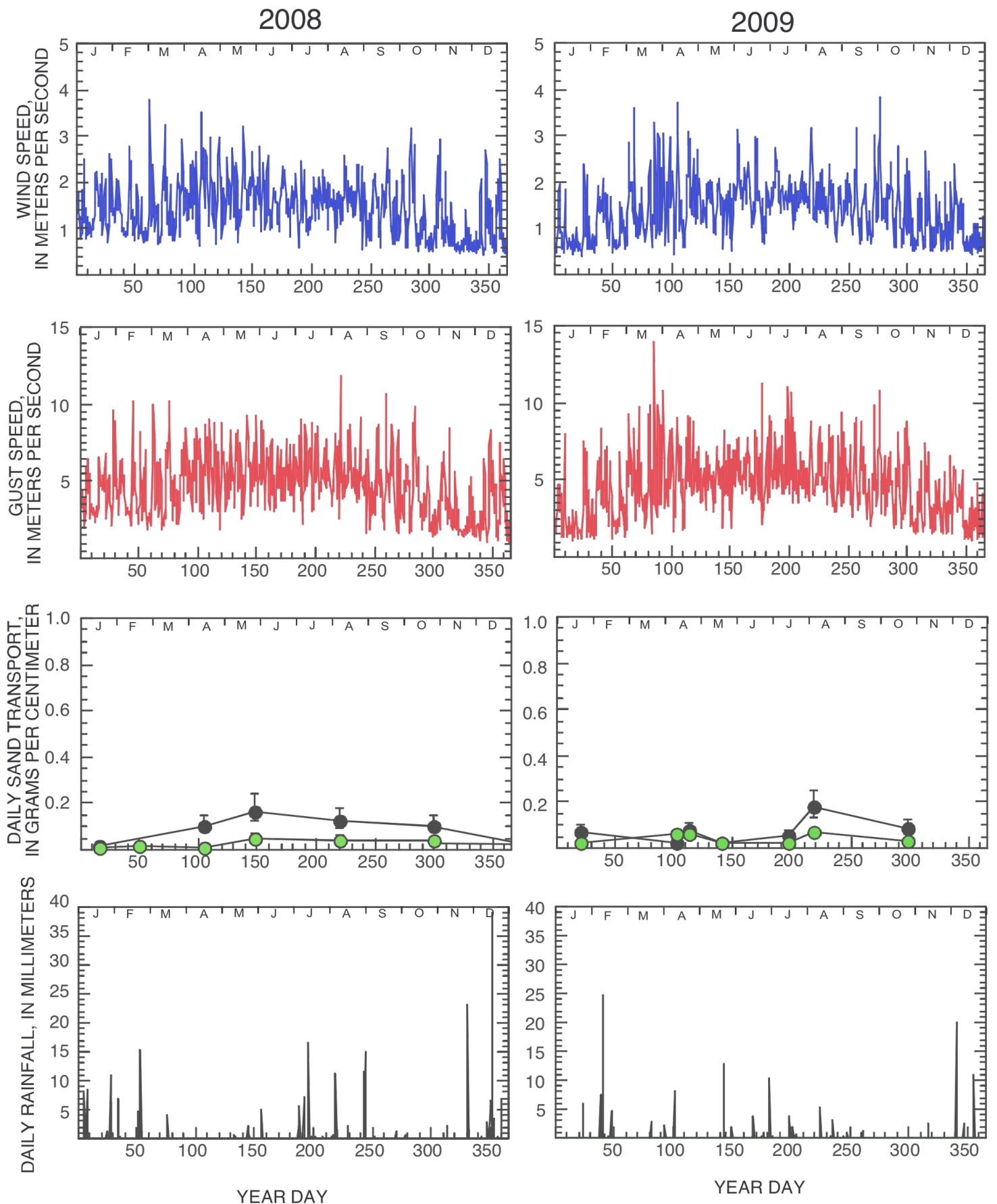

Figure 65. Wind, aeolian sand-transport, and rainfall data collected at the instrument station AZ G:03:0072 U, and aeolian sand-transport data collected in sand traps at AZ G:03:0072 L (green circles), in the Colorado River corridor, Grand Canyon, Ariz., in 2008 and 2009. Daily sand transport is plotted in grams, normalized to a width of $1 \mathrm{~cm}$. To obtain these values, total sand mass collected from four traps during each maintenance visit was divided by number of days since traps had last been emptied. Wind speed (blue plot $)$ is presented as diurnal average values, using daytime (0600-1800 h) and nighttime $(1800-0600 \mathrm{~h})$ averages of data collected at 4-minute intervals. Gust speed (red plot) is 
shown as maximum values that occurred during each diurnal interval. Rainfall is plotted as daily (24-hour) totals.
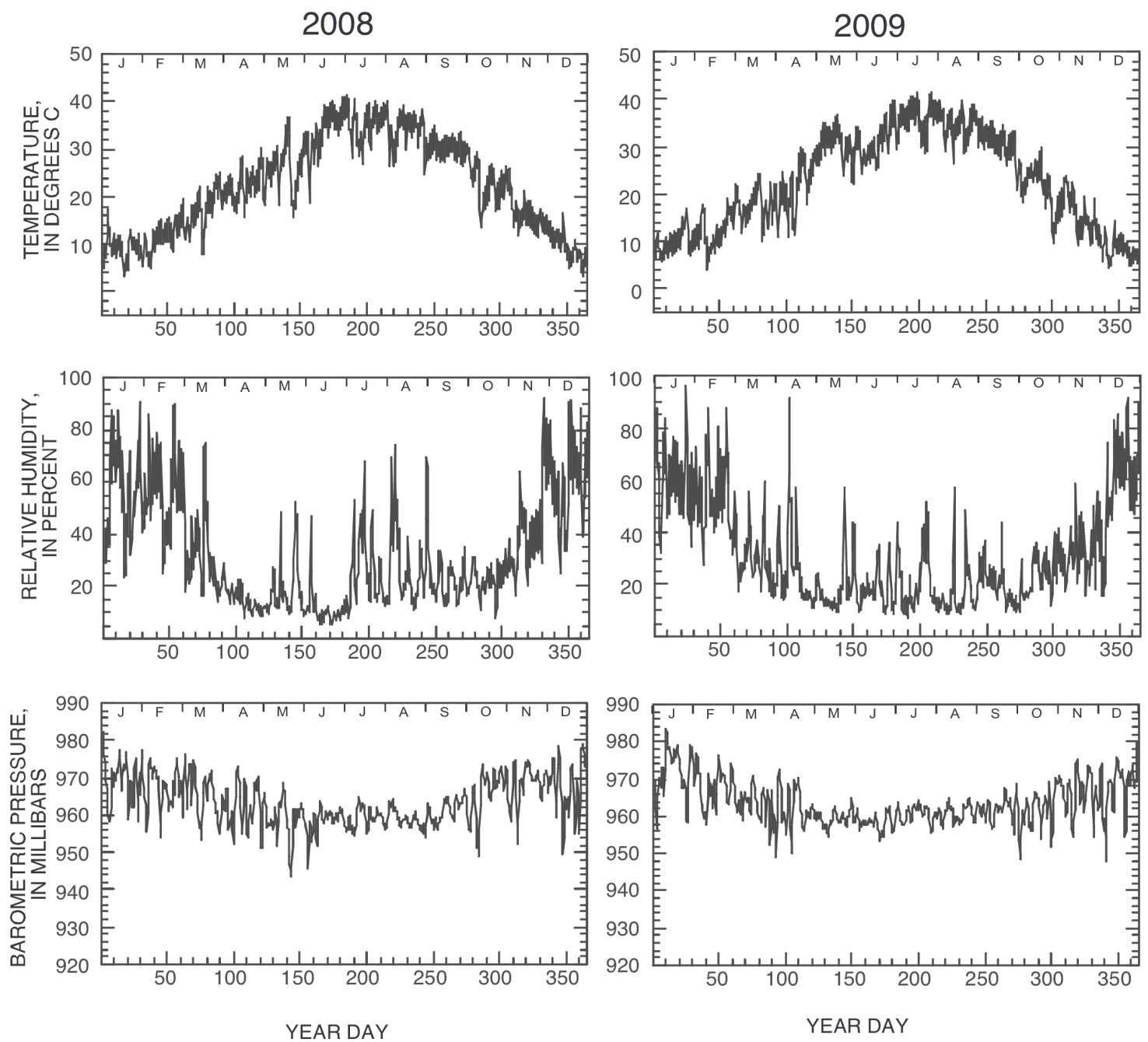

Figure 66. Temperature, humidity, and barometric pressure data collected at the instrument station AZ G:03:0072 U in the Colorado River corridor, Grand Canyon, Ariz., in 2008 and 2009. All parameters are plotted as diurnal averages (defined using 0600-1800 and 1800-0600 h). 